\title{
GEORGE GROTE ON PLATO AND
} ATHENIAN DEMOCRACY

\author{
submitted by
}

Kyriacos Demetriou

for the degree of Doctor of Philosophy

University College London

1993

ROMUL.

uxy: 
ProQuest Number: 10017706

All rights reserved

INFORMATION TO ALL USERS

The quality of this reproduction is dependent upon the quality of the copy submitted.

In the unlikely event that the author did not send a complete manuscript and there are missing pages, these will be noted. Also, if material had to be removed, a note will indicate the deletion.

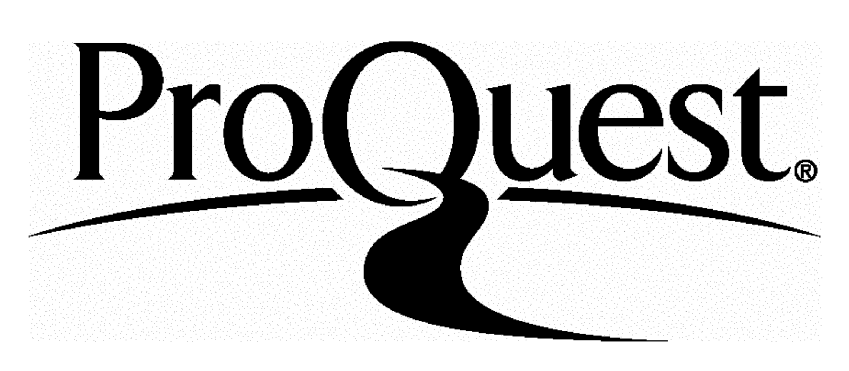

ProQuest 10017706

Published by ProQuest LLC(2016). Copyright of the Dissertation is held by the Author.

All rights reserved.

This work is protected against unauthorized copying under Title 17, United States Code. Microform Edition $\odot$ ProQuest LLC.

\author{
ProQuest LLC \\ 789 East Eisenhower Parkway \\ P.O. Box 1346 \\ Ann Arbor, MI 48106-1346
}




\begin{abstract}
The object of this thesis is to present a critical examination of George Grote's account of Plato and Athenian democracy. The research provides a fresh interpretation of Grote's arguments, and is based on his published works and manuscript unpublished essays. New material is traced concerning the reception and influence of his works on Plato and Athenian democracy in the nineteenth century. Grote is presented as a distinguished classical scholar, and it is suggested that his commitment to utilitarianism did not affect the arguments of his historical writings. Grote's connection with James and John Stuart Mill is also explored. In his time Grote was criticized for being hostile to Plato. Here it is argued that he thought of himself as providing a defence of Plato. This is elaborated by showing that his criticism of Plato forms a part of his conception of Athenian democracy. In a consideration of Grote's appraisal of Athenian democracy within the context of previous works on the subject, emphasis is placed on his unique appreciation of the 'liberal' movement of the fifth century B.C. Grote contrasted Plato's political ideals with the many-sided achievements of the Athenian constitution. However, Grote defended Plato to the extent that he did not conceive of him only as a critic of liberal institutions. He sought to disentangle Plato's thought from religious and metaphysical doctrines which had dominated preceding attempts to interpret Platonic philosophy. The thesis contends that Grote's contribution marked the beginning of a new period in classical research. His overall picture of Athenian democracy and the sophists, together with his original view of Plato's thought, changed the way scholars understood the philosophy and political thought of ancient Greece.
\end{abstract}


CONTENTS

\author{
ABSTRACT 2 \\ CONTENTS 3 \\ ACKNOWLEDGEMENTS 6
}

\title{
INTRODUCTION 7
}

I. Object and Scope of the Thesis 7

II. Structure of the Thesis 11

\section{CHAPTER 1 \\ GROTE AND HIS CONTEMPORARIES 15}

I. Grote's Early Influences 15

II. Acquaintance with James Mill 21

III. A lifelong relationship with J.S.Mill 39

V. Conclusion 55

\section{CHAPTER 2}

IN DEFENCE OF ATHENIAN DEMOCRACY:

THE TRADITIONAL APPROACH AND GROTE'S POSITION 57

I. The Greek Sources 57

II. The British 'Mixed' Constitution far Preferable to

Athenian Democracy 62

III. The Need of Rewriting Ancient Greek History 71

IV. Grote's Early Pieces 76

\section{CHAPTER 3}

ATHENIAN DEMOCRACY RECONSIDERED 83

I. Solonian Constitution - Not Democratic 83

II. The Senate of Areopagus 85

III. In Defence of Ostracism 89

IV. The Athenian Empire 95

V. Cleon and the Role of Demagogues in Ancient Democracy 102

VI. The Athenian Character 114

VII. Remarks on Sparta 122 


\section{CHAPTER 4}

THE DEBATE OVER GROTE'S HISTORY OF GREECE 128

I. Defects Existing in Earlier 'Histories' 129

II. Different Views Concerning the Application of Modern

Concepts to the Explanation of Ancient Politics 133

III. The Athenian Democracy, Character, Constitution, and Empire Reestimated under Grote's Impulse 137

(i) The Athenian Democracy Reexamined 137

(ii) The Athenian Character Reconsidered 139

(iii) On the Courts and Constitution of Athens 141

(iv) On the Athenian Empire 145

IV. The Demagogues 148

V. Ostracism 153

VI. The Spartan Character and Constitution 155

VII. Grote's Achievement 157

APPENDIX: Greek Historians and George Grote 160

\section{CHAPTER 5 \\ PLATO AND PLATONISM IN BRITAIN AGAINST ENLIGHTENMENT 163}

I. Age of Socratism 164

II. Anti-Platonism 170

III. Platonic Idealism as Contrasted with Utilitarianism 178

IV. Remarks- Grote's Position 185

\section{CHAPTER 6 UNDERSTANDING PLATO 191}

I. Approach to Plato 192

II. Plato's Authoritarianism Condemned 209

(i) Plato's Political Aspirations and Athens 209

(ii) Plato's Political Ideal as Contrasted to Athenian Democracy 213

APPENDIX A: German Platonism 219

APPENDIX B: The Authenticity of the Corpus Platonicum 224

\section{CHAPTER 7}

THE SOPHISTS AND SOCRATES REVISITED 230

I. The Sophistic Enlightenment 230

(i) In Defence of the Sophists 232

(ii) Assessment of Protagorean Philosophy 238

II. Socrates the Sophist and the Athenians 241

(i) Socrates the Sophist 242

(ii) Socrates' Negative Dialectic 246 
(iii) The Decision of the Athenians to Condemn Socrates 250

CHAPTER 8

THE RECEPTION OF GROTE'S IDEAS ON THE SOPHISTS AND SOCRATES 256

I. The Sophists 256

II. Socrates 264

\section{CONCLUSION 272}

\section{BIBLIOGRAPHY 281}

I. Manuscripts and works of George Grote 281

II. General Bibliography 282 


\section{ACKNOWLEDGMENTS}

I owe a particular debt of gratitude to my supervisor Professor Fred Rosen for the guidance and generous encouragement he has offered me over the last years. An accomplished scholar and demanding critic, Professor Rosen could at once be patient and enthusiastic. His many-sided assistance in the course of my project was such as I can never forget. Over the years I have learned a great deal from Professor Paschalis Kitromilides, both from his writings and from his example of unflagging industry. I had the privilege of studying with Professor Kitromilides as an undergraduate in Athens, and it is under the impact of his inspired teaching and personal support I was introduced to political philosophy. I would like also to express my deepest thanks to Mr. Peter Nicholson whose support in my initial steps as a postgraduate in York was generously provided. My discussions in political philosophy with Mr. John Horton were stimulative and highly instructive. I have also benefited a great deal from conversations with Dr Tim Cornell, which enabled me to understand the spirit of nineteenth century historical debates. I must also thank Dr Dimitris Bourantonis and Mr. Gregory Molivas who have been untiring friends and found ways to help this research being completed. My thanks are also due to the staff of the British Library; University of London Library (Senate House); University College Library as well as to the department of History of University College.

Without the generosity of A.G.Leventis Foundation this work would never have been written. I am especially grateful to Mr. A.G.Exarchos and Mr. C.Cassimatis with whom I kept correspondence all these trying years.

My indebtedness to my wife, Chrysa, is beyond measure, as it is to my parents, to whom the thesis is duly dedicated. 


\section{INTRODUCTION}

I

\section{Object and Scope of the Thesis}

The purpose of the present thesis is to examine critically George Grote's interpretation of Plato and Athenian democracy. The thesis sets out to consider Grote's arguments in the context of nineteenth-century debates on these themes in the history of political thought. Among earlier studies, there are two full biographies of Grote. The first was written by Harriet Grote, and was based on her diary notes and personal recollections. ${ }^{1}$ The biography composed by M.L.Clarke in 1962 was broader in its scope and corrected and supplemented Mrs Grote's account. ${ }^{2}$ Though some additions have been made to Clarke's work, the thesis is not primarily meant to be biographical. There are several additional works to be mentioned, which, though not confined to Grote, contribute variously to our understanding of his writings. William Thomas included Grote in one of his Nine Studies of the Philosophic Radicals. ${ }^{3}$ Thomas dealt with Grote's politics and considered his role as the political leader of the Radical movement. Frank Turner in The Greek Heritage in Victorian Britain attempted to explain Grote's 'uncommon' approach to ancient Greece in the context of his role as a Philosophic Radical. ${ }^{4}$ The same approach was adopted recently by Peter Spahn in

${ }^{1}$ Harriet Grote, The Personal Life of George Grote, London 1873.

${ }^{2}$ M.L.Clarke, George Grote: A Biography, London 1962.

${ }^{3}$ W.Thomas, The Philosophic Radicals, Nine Studies in Theory and Practice 1817-1841, Oxford 1979, pp. 406-38.

${ }^{4}$ F.M.Turner, The Greek Heritage in Victorian Britain, New Haven and London 1981. 
his "George Grote, John Stuart Mill und die antike Demokratie".5 Spahn's Grote is the utilitarian historian of Greece. The novel arguments in the History of Greece are ascribed to a tendency to read history in light of the principle of utility. Turner's and Spahn's disposition to connect Grote's historical arguments with party interest and utilitarian influence was shared by the historian's contemporary critics. This preoccupation with Victorian politics as the key to our understanding of Grote has led to an underestimation of his significance as a classical scholar, and, as an interpretation of his thought, is challenged by the argument of the thesis. The History of Greece, it is here contended, opened new avenues for the development of classical studies in Britain and Germany. Grote's commitment to utilitarianism is given due consideration, but unlike the studies mentioned above, is not referred to as a major influence in his historical arguments. Grote's adherence to "Experience philosophy", as J.S.Mill noted, ${ }^{6}$ was the source of his originality and distinction. Mill meant that Grote respected evidence, and aspired to submit all historical issues to the tribunal of reason.

In the twentieth century Grote is mostly included among the critics of Plato. Karl Popper admitted that Grote's interpretation of Plato's political philosophy had much in common with his own. ${ }^{7}$ Eminent Platonists of the nineteenth century, like

${ }^{5}$ P.Spahn, "George Grote, John Stuart Mill und die antike Demokratie", in Der Klassische Utilitarismus (ed. Ulrich Gahde and Wolfang H.Schrader), Berlin 1992, pp. 145-171.

${ }^{6}$ Mill, "Grote's Plato", in Collected Works (ed.J.M.Robson), vol. XI (Essays on Philosophy and the Classics), p. 440.

${ }^{7}$ See Karl R.Popper, The Open Society and Its Enemies, London 1952 (second ed.), vol. I, p. 216. William C.Greene conceived of Grote as the acknowledged predecessor of anti-Platonists. See "Platonism and its Critics", Harvard Studies in Classical Philology, 61(1953):41. See also Warner Fite, The Platonic Legend, London 
Benjamin Jowett and John Stuart Blackie, maintained that Grote's 'hostility' towards Plato was the result of his inability to appreciate Plato's so-called Idealism. Here it is objected that the "prince of Victorian Platonists", as Vlastos recently called Grote, ${ }^{8}$ thought of himself as providing a defence of Plato. The arguments in his Plato and the Other Companions of Sokrates as well as the philosophical assessment of Plato's thought, his attack on German Platonism, and his confession that he felt indebted to the ancient philosopher indicate that he was justified in conceiving himself as defending Plato. Grote's Plato was the first work in Britain which attempted to disentangle Plato's thought from religious and metaphysical doctrines. Earlier works on Plato, throughout the eighteenth and the first half of the nineteenth centuries, were preoccupied with the philosopher's theology and 'mysticism'. Plato was often attacked on religious grounds. Grote originated the philosophical analysis of Plato.

Grote's disapproval of some aspects of Plato's politics is not interpreted here as the result of the distance between his and Plato's philosophical points of view. Grote disliked Plato's political ideals not because Grote was a utilitarian, but because of his attitude towards democratic Athens. Grote's criticism of Plato is understood as forming a part of his unique conception of Athenian democracy. This conception is explored in analyses of such issues as the role of the demagogues in ancient democracies, the justification of the institution of ostracism, the action and ideology of Athenian imperialism, and the character of Spartan politics. Grote's rehabilitation of the sophists will be interpreted through his estimation of Athenian democracy. His

1934, p. 4.n.7; Turner, The Greek Heritage in Victorian Britain, p. 401.

${ }^{8}$ Gregory Vlastos, Socrates, Ironist and Moral Philosopher, Cambridge 1991, p. 4. 
account of the trial of Socrates is examined in terms of a reaction of Athenian democrats against the manners of the elderly dialectician. Similarly, Grote contrasted Plato's proposals in the Republic and the Laws with the achievements of the Athenian constitution.

The analysis of Grote's arguments has been supported by hitherto little-known material. The collections of Grote's unpublished essays in the British Library and in the Senate House library of the University of London were particularly valuable. This material has added to what is already known through the published works, and has been used primarily to show Grote's constancy to the central ideas of his arguments. When necessary, passages from Grote's manuscripts have been cited to indicate his sources.

The present account would be incomplete without exploring Grote's connection with James and John Stuart Mill. The nature of their influence on Grote, and their 'Platonism' as compared with Grote's, are considered for the first time here. Grote's History of Greece formed a response to previous historians, whose works, written at the time of the French Revolution, differed substantially in approach and argument. Some sources related to this issue are not generally familiar. The reception of Grote's ideas by his contemporaries is surveyed, and unknown material from Victorian and American journals is uncovered. Grote's Plato, which is supposed to have been a continuation of the History, is placed in its intellectual context. Attention is paid to Grote's reaction to certain aspects of German Platonic analysis. An attempt is made to point out the major tendencies in Platonic analysis in the eighteenth and nineteenth centuries. This particular part of the research, apart from the new material it brings to light, serves the purpose of defining the idea of Grote's defence of Platonism. 


\section{II}

\section{Structure of the Thesis}

The thesis is designed to lead gradually to the elaboration of Grote's historical analysis, as centred on his understanding of Athenian democracy, and to shed new light on his general view on Plato and Platonism. This was made easier by using a chronological structure to examine Grote's arguments. The thesis concludes that a new period in classical research began under the influence of his works.

The first chapter provides an account of Grote's early influences. It focusses on the connection between Grote, James Mill, and John Stuart Mill. Unlike Bentham, who was indifferent to Platonic philosophy, the Mills displayed a deep interest in Plato. This interest is shown to have been rooted in the 'negative' aspect of Platonic thought. James Mill, in his effort to set Plato's philosophic character free from Neoplatonic interpretation, refused to acknowledge the existence of a dogmatic side to Platonism. The younger Mill declared himself a Platonist in the sense of attaching a unique importance to the method of dialectic. John Stuart acknowledged the existence of a 'positive' aspect to Plato's thought. He assumed, however, that Plato himself, conceived of his doctrines as philosophic conjectures. Though Grote appreciated Plato's contribution to the development of dialectical method of enquiry, he took seriously Plato's dogmatic side. In his great constructive works, Plato, assumed the character of a political innovator, and displayed his dissatisfaction with Athenian democratic institutions. In examining Grote, scholars have placed too much emphasis on the Mills' influence. It is argued that Grote distinguished himself as a classicist in a way that none of the other utilitarians did.

Chapter two looks at the treatment of Athenian democracy before Grote. 
Emphasis is placed on the works of the British historians at the time of the French Revolution. Athenian democracy was presented then as an inferior model of a system of government. Athenian political life, with its disruptive factionalism, offered, in their view, an historical lesson: namely, that democracy was something to be avoided at all costs. Grote's early pieces on Greek history revealed his intention to correct the various misrepresentations that surrounded Athenian democracy.

A critical exposition of Grote's appreciation of Athenian democracy follows in chapter three. Grote reconsidered the major aspects of Athenian constitutional life, and showed where these aspects were misinterpreted. His remarks on political reforms, his explanation of the origin and object of ostracism, and the rehabilitation of Cleon in the context of a wider understanding of the role of demagogues in ancient democracies, his judgement on the policy and raison d' etre of the Athenian empire, and his favourable account on the character and general temper of the Athenian democrats, and his critique of Sparta, are shown to have established a break with the traditional approach to these issues.

The originality of Grote's arguments is elaborated through the examination of their reception by his contemporaries. The aim of chapter four is to establish the impact of Grote's History of Greece upon nineteenth-century classical scholars. It is shown that under his influence scholars reestimated Athenian democracy. Some scholars were, of course, puzzled by the novelty of his arguments, and others objected to what they took to be a 'polemical vein' which characterized them.

Having defined Grote's conception of Athenian democracy the thesis goes on to consider his analysis of Plato's philosophy. The major tendencies in British Platonic studies in the eighteenth and first half of the nineteenth centuries are discussed in 
chapter five. The period is described as the 'age of Socratism'. Scholars treated Plato with hostility. Plato, it was thought, had departed from Socratic doctrines, and developed his peculiar, inconsistent and mystical theories. Platonic philosophy aroused an interest immediately before Grote published his works, but it was motivated by the desire to present it as an antidote to scientific experimentalism and utilitarian ethics.

Grote's approach to Plato's philosophy is discussed in the sixth chapter. He disagreed with distinguished German Platonists who insisted on the unity of Plato's thought. This led them to reject a number of dialogues as spurious. Grote developed the Thrasyllian distinction between the dialogues of search and the dialogues of exposition. He argued that the negative (searching) group grew out of distinct views, which valued the spirit of investigation per se, and advocated the liberty of dissenting opinion. This group was not related to the positive doctrinal phase of Platonism in the sense of providing adequate answers to the questions raised in the other group. In this chapter it is shown that Plato's positive works were not an 'anathema' to Grote, as Turner put it. ${ }^{9}$ Grote found many things to praise in Plato's constructive pieces. His critique of Plato's political ideals is explained in terms of the historical appraisal of Athenian democracy.

Chapter seven has a two-fold purpose: to analyse Grote's rehabilitation of sophistic thought and to discuss his interpretation of Socrates' trial and condemnation. For Grote the sophists were worthy teachers of civic virtue and democracy. He emphasized Protagoras' contribution to the cultivation of democratic consciousness. Plato, he believed, was not favourably disposed towards sophistic teaching on the grounds of political ideology. The Athenians, in Grote's judgement, were not

\footnotetext{
${ }^{9}$ Turner, Greek Heritage in Victorian Britain, p. 388.
} 
unjustifiably exasperated by Socrates, as Socrates' religious, personal, and political views brought him into conflict with the leading ideas of his age and country.

The last chapter examines the reception of Grote's arguments on the sophists and Socrates. Grote succeeded in challenging the old interpretations regarding them. After Grote there was a growing tendency to place the sophistic movement in the context of ancient democracy, and to estimate its contribution to the development of philosophical thought. Grote was influential in questioning the prevalent idea of Socrates as a professional enemy of the sophists. If Socrates, however, met with the hostility of his contemporaries, it was because unlike the sophists he disapproved of the established democratic sentiment. 


\section{Chapter 1}

\section{GROTE AND HIS CONTEMPORARIES}

I

\section{Grote's Early Influences}

In setting out to examine Grote's writings it is important to discuss his relationships with two important utilitarians: James and John Stuart Mill. Bentham is excluded here for two reasons: firstly, because the impact he had upon Grote, as well as upon other utilitarians, is rather self-evident to warrant individual treatment; and, secondly, because Bentham had nothing substantial to say about ancient Greece. If Bentham, however, was the father of the school of utilitarian thought, James Mill was its indefatigable administrator. And James Mill's influence upon Grote's thought was much more direct and personal than Bentham's.

James Mill's role in the utilitarian movement cannot be overestimated. In the words of J.H.Burns, Bentham, left to himself, "would never have founded a school or launched a movement, for all his ambitions and dreams". ${ }^{1}$ It was James Mill's energy and imposing personality which bestowed an ideological colouring to Bentham's philosophy, by rendering its main principles intelligibly simple, and effectively more dogmatic. $^{2}$ It is $d i x$ him that political thought at the time of the Reform settlement stood at a high level of "sobriety". His place, Bain believed, "could not have been

1 J.H.Burns, "Bentham and the French Revolution", Transactions of the Royal Historical Society, 5th ser., 16(1966):113. Further see R.Borchardt (ed.), Four Dialogues of Plato, trans. by J.S.Mill, London 1946, p. 3.

${ }^{2}$ Elie Halevy, The Growth of Philosophic Radicalism, London 1934, p. 307. 
taken by any other man that we can fix upon". ${ }^{3}$ His intellectual influence upon others must have been very strong. As his son, John Stuart, wrote, by "his writings and his personal influence he was a great centre of light to his generation".4

In his manuscripts which date before 1818 , Grote shows a remarkable familiarity with the ancients, initially with poets like Homer, but soon with philosophers and historians as well, like Plato, Pausanias and Strabo. Homer occupied a considerable part of his early Greek studies; some notes on the Timaeus may be dated as early as 1818 . Other pieces, as for instance his school exercises and notes before 1809 , reveal his growing familiarity with the ancient Greek language. ${ }^{5}$ There can also be found early notes on Euripides, Hesiod, Xenophon, and Cicero. ${ }^{6}$ It appears that Grote was already interested in the ancients when he became acquainted with James Mill and the utilitarian circle.

Mrs Grote mentioned as his first influential relationships those with David Ricardo, ${ }^{7}$ Charles Cameron, and George Norman. ${ }^{8}$ Cameron, a jurist, disciple of

${ }^{3}$ Alexander Bain, James Mill. A Biography, London 1882, p. 447.

${ }^{4}$ J.S.Mill, Autobiography (ed. Jack Stillinger), London and Oxford 1971, p. 123.

${ }^{5}$ See Grote's "Early exercises at Charterhouse, at about the age of eleven or twelve-1805-1806", University of London Library, MS.429/1.

${ }^{6}$ Grote's "Verse Translations and Miscellaneous Notes from 1809 to 1824", BL Add. MS 29,527; see on Homer fos. 49-53; on the Timaeus fo. 69; on Euripides fos. 64-8; on Xenophon's Cyropaedia, fos. 89-94.

${ }^{7}$ Whom he met in 1817; H.Grote, The Personal Life of George Grote (thereafter Personal Life), London 1873, p. 12.

${ }^{8}$ Personal Life, p. 13; and L.Stephen, "Cameron, Charles Hay", Dictionary of National Biography (thereafter D.N.B.), London 1886, vol. VIII, pp. 288-9. Norman, a liberal in politics, had an early intimate friendship with Grote; see G.C. Boase, "Norman George Warde", D N.B., London 1895, vol. XLI, p. 112. It was Norman who introduced Grote to Harriet Lewin in 1814, who afterwards became his wife; see M.L. 
Jeremy Bentham, and well read in classical literature, conducted Grote, according to Mrs Grote's testimony "on the great path of development, both of character and objects of study". ${ }^{9}$ The turning point of Grote's life might be dated from this period. Elsewhere Mrs Grote emphasized that Grote "had been trained to political studies in the severe school of Bentham and Mill," but she should not be understood as referring to a very early stage of his education..$^{10}$ Among his later influences may be listed Auguste Comte. Grote met him on the occasion of his visit to Paris in 1843, and he was impressed by his work La Philosophie Positive, then recently published. ${ }^{11}$ On returning to London Grote made efforts to promote the circulation of Comte's works. In a letter to George Lewis (27 May 1851) Grote declared himself in agreement with Comte's classification of the stages of the human mind. He also acknowledged that the differences in the interpretation of phenomena (corresponding to different stages of social development) deserved serious consideration. ${ }^{12}$

It appears from Grote's correspondence with Bentham that they held regular meetings, and that the Grotes treated the venerable philosopher with great respect. ${ }^{13}$

Clarke, George Grote. A Biography, London 1962, p. 10.

${ }^{9}$ H.Grote, Personal Life, p. 15.

${ }^{10}$ H.Grote, The Philosophical Radicals of 1832, London 1866, p. iv.

${ }^{11}$ H.Grote, Personal Life, pp. 157-8. See in addition Leslie Stephen's remarks in The English Utilitarians, London 1900, vol. III (J.S.Mill), p. 343.

12 See H.Grote, Personal Life, pp. 203-4; also History of Greece (thereafter History), London 1888, 1:333n.

13 BL Add. MS 33,546, fos. 55, 60, 165-6. Grote in a letter to Bentham (2 February 1830) expressed openly his reverence and admiration for the old philosopher; see fos. 371-2. About Bentham and his visits to the Grotes, see H.Grote, Personal Life, pp. 80-81. 
Mrs Grote surprisingly hardly referred to Bentham, and in the Personal Life she said nothing respecting Grote's and Bentham's collaboration on the publication of the latter's work, entitled Analysis of the Influence of Natural Religion on the Temporal Happiness of Mankind. ${ }^{14}$ This book appeared in 1822 under the pseudonym Philip Beauchamp, and was republished by Grote himself in 1866 for private circulation. After the death of her husband Mrs Grote gave the manuscript (upon which Bentham had worked from 1815) to the British Museum with his covering letter of suggestions of how to use them. As Robertson rightly pointed out, a comparison of the manuscript with the printed volume reveals the extreme amount of labour required to bring them into form. ${ }^{5}$ Grote, argued Robertson "had practically to write the essay, leaving aside the greater part of the materials before him and giving to the remnant a shape that was his rather than Bentham's". ${ }^{16}$ The book applied a destructive criticism to the idea of the utility of religious belief; "religion, considered with reference to the present life, is not beneficial but pernicious". ${ }^{17}$ Religion is conceived as holding a power radically

\footnotetext{
${ }^{14} \mathrm{H}$.Grote's only reference is to be found in a note prefixed to the selection of the Minor Works of George Grote, ed. by A.Bain (thereafter Minor Works), London 1873, p. [18]: (Pages in brackets indicate the introductory section of the M.W., written by Bain himself.) Grote, we learn, "bestowed much time upon some MSS of Jeremy Bentham's, which the venerable sage entreated his young disciple to put into a readable form".

${ }^{15}$ Bentham sent a number of boxes with written material to Grote on the 9 December 1821 trusting that his "tactical powers will make a good use of it". "Truly sorry I am" wrote Bentham "that the demand for labour on it should be so great...", etc. (BL Add. MS 29,806, fo. 4.) Basil Willey does not exaggerate when he states that the Natural Religion was composed by both Bentham and Grote (Nineteenth Century Studies. Coleridge to Matthew Arnold, New York 1949, p. 134).

${ }^{16}$ G.C.Robertson, "George Grote", D.N.B., London 1890, vol. XXIII, p. 285.

${ }^{17}$ Philip Beauchamp (pseud. of the editor, George Grote), Analysis of the Influence of Natural Religion on the Temporal Happiness of Mankind, London 1822, p. 3. A similar argument can be found in James Mill's History of British India, London 1817,
} 
hostile to the intellectual progress of society, and God with his omnipotence as to rewards and punishments is described as an irresponsible and egoistic despot. ${ }^{18}$ It is worth observing here that one of Grote's unpublished essays entitled "Expectations of pleasure and pain in a future life," reproduced in substance Bentham's central argument in Natural Religion. "Religious torments (or the expectation of them) most painful to an individual first at the time when the terrors which they impress can be of no benefit to mankind." ${ }^{19}$ Bentham referred to Plato once in this work in a lengthy note. He did not show much respect for Plato. On the contrary, he spoke of Plato as a representative of intuitionism, who provided not the smallest evidence for his arguments. ${ }^{20}$ In general, Bentham appears not to have been sympathetic either to Socrates or Plato. In the Deontology he did not hesitate to say that "While Xenophon was writing history, and Euclid giving instructions in geometry, Socrates and Plato were talking nonsense, under pretence of teaching wisdom". ${ }^{21}$ What is of concern here is that Grote successfully submitted to his first lesson in the philosophy of Experience, which he, in time to come, would have developed into a historical method. In this respect his editorial assistance in the publication of Bentham's work

vol. I, p. 285.

${ }^{18}$ Natural Religion, p. 33.

${ }^{19}$ BL Add. MS 29,528, (1818-1822) fo. 76.

${ }^{20}$ Natural Religion, pp. 19-20n.

${ }^{21}$ Deontology, ed. A.Goldworth, Oxford 1983, p. 135. In the same work Bentham also called Plato "the master manufacturer of nonsence" (p. 137; see also p. 146). See also the passage quoted from his Theory of Legislation in R.Jenkyns, The Victorians and Ancient Greece, Oxford 1980, p. 247. 
should be accounted among his most momentous influences. ${ }^{22}$

Further, Bentham's influence appears strikingly in Grote's early essay "On Magick". Magic, like religion, is sustained by a priori suppositions in the existence of agencies of excessive and undesirable powers, which lie "beyond the limits which experience authorises". A belief in magic, wrote Grote, "may be generally defined as supposing the existence of agency of certain excessive powers, or extending the action of those powers with which we are acquainted to an height beyond the limits which experience warrants". ${ }^{23}$ These "supernatural agencies", are obviously undemonstrable and unreconcilable with the pure facts of experience. ${ }^{24}$ What Bentham had tried to perform in the field of religion, Grote tried to do with magic.

These introductory remarks would be incomplete without suggesting that Grote was influenced by German scholars. ${ }^{25}$ Together with J.S.Mill he showed a great respect for the 'celebrated' Schleiermacher, to whom Grote had once offered his hospitality. ${ }^{26}$ German scholars were then pioneers in classical studies, and Grote as

\footnotetext{
${ }^{22}$ The young men, according to W.Smith, who were accustomed twice a week to meet at Grote's house in the City, and discussed various subjects on metaphysics and mental philosophy regarded "Jeremy Bentham ... as a kind of deity, whose utterances were carefully watched and reverently received. James Mill was their prophet, who exercised uncontrolled sway over their minds" ("George Grote", Quarterly Review, 135(1873):109).

${ }^{23}$ G.Grote, "On Magick" (1820), BL Add. MS 29,531, fos. 1, 67. (The essay has been recently published, in W.M.Calder (ed), The Cambridge Ritualists Reconsidered, Atlanta 1992.)

${ }^{24}$ Ibid., fos. 58-9.

${ }^{25}$ This influence was overrated by William Mure, in his Remarks on two appendices to the second volume, third edition, of Mr. Grote's History of Greece, London 1851, p. 7. More on the German scholars and their influence on Grote is to be found in ch. 6. App. A.
}

${ }^{26}$ H.Grote, Personal Life, p. 48. 
the bulk of German books he left in his library testifies, did not neglect to study their works with genuine interest.

A German scholar who, along with Schleiermacher, might have exerted an influence on Grote was Friedrich Ast. In his Platons Leben und Schriften Ast maintained that the "Platonic writings are not connected by any philosophical system ... nor any scientific sequence can be detected which interrelates them". ${ }^{27} \mathrm{He}$ dwelt upon the separate individuality of each dialogue, and emphasized Plato's object of intellectual stimulation, ${ }^{28}$ but he did not follow through his views consistently. Thus he arrived at a position by which he rejected as spurious a great number of Platonic compositions. Grote furthermore concurred with Bonitz in pointing out how little was known about the historical circumstances of Plato's intellectual and philosophical development. $^{29} \mathrm{He}$ also confessed his agreement with Strumpell in assuming the impossibility of determining chronologically, from scant pieces of evidence, by what successive steps Plato's thought departed from the original Socratic views. ${ }^{30}$

\section{II}

\section{Acquaintance with James Mill}

James Davies once remarked that Grote's "prophets" were Ricardo and James

${ }^{27}$ F.Ast, Platons Leben und Schriften, Leipzig 1816, p. 40, my translation. See Grote's comments in Plato and the other companions of Sokrates (thereafter Plato), London 1865, 1:174n.

${ }^{28}$ Ast, Ibid., pp. 38-9.

${ }^{29}$ Plato, 1:193n. Grote alluded to Hermann Bonitz's Platonische Studien, Wien 1858 , p. 5.

${ }^{30}$ Plato, 1:193n. Grote referred to Ludwig Strumpell's Geschichte der Praktischen Philosophie der Griechen, Leipzig 1861, p. 294. 
Mill. ${ }^{31}$ Grote came under Mill's personal influence at a relatively early date, and remained one of his most faithful disciples for the rest of his life. In his introductory remarks to the review of J.S.Mill's The Philosophy of Sir W.Hamilton Grote devoted "a few words to the fulfilment of another obligation". ${ }^{32}$ James Mill's life, according to Grote, was a striking example of one who dedicatedly carries out the Platonic ideal of Dialectic, Tou didonai kai dehesthai logon (the giving and receiving of reasons). ${ }^{33}$ His pursuit of the Platonic pattern, combined with a vigorous character consistently devoted to truth, explains, Grote continued, why this man exercised a great intellectual ascendancy over younger minds. Several have profited from his society, and remember with gratitude this noble figure; among them, Grote admitted, "the writer of the present article, who owes to the historian of British India an amount of intellectual stimulus and guidance such as he can never forget". ${ }^{34}$

Grote was introduced to James Mill by Ricardo in 1819, and his first impressions were rather discouraging; yet, as J.S.Mill observed, he subsequently "sought assiduously his society and conversation". ${ }^{35}$ In May 1819 Grote was writing

31 J.Davies, "George Grote", Contemporary Review, 22(1873):394. Grote, according to G.W.Greene, talked "like the friend of Ricardo and the two Mills" ("Reminiscences of George Grote", Atlantic Monthly, 44(1879):772). According to Halevy, Grote was "the disciple of James Mill" (The Growth of Philosophic Radicalism, p. 418).

32 Bain, Minor Works, p. 283.

${ }^{33}$ Ibid., p. 284.

${ }^{34}$ Ibid.

35 J.S.Mill, Autobiography, p. 46: "Already a highly instructed man," Mill continued, Grote "was yet, by the side of my father, a tyro on the great subjects of human opinion; but he rapidly seized on my father's best ideas". See further, H.Grote, Personal Life, p. 21. 
to Norman:

I have met Mill often at his house, and hope to derive great pleasure and instruction from his acquaintance. ... His mind has, indeed, all that cynicism and asperity which belong to the Benthamian school, and what I chiefly dislike in him is, the readiness and seeming preference with which he dwells on the faults and defects of others - even of the greatest men! But it is so very rarely that a man of any depth comes across my path, that I shall most assuredly cultivate his acquaintance a good deal farther. ${ }^{36}$

And so he did. Grote, as his wife testified, chiefly sought instruction from James Mill, and not only on political economy, but on a wide range of philosophical issues. A few months later "the ascendency of James Mill's powerful mind over his younger companion made itself apparent". ${ }^{37}$ James Mill's two conspicuous characteristics, viz., his resolute antipathy towards aristocratic or monarchical government, together with the strongest conviction in favour of democracy; and his profound opposition to the established Church, ${ }^{38}$ were gradually imparted to Grote who finally adopted all the antipathies of his teacher. One of Grote's biographers lamented that his "gentle and generous nature was warped and distorted by James Mill's fanatic antipathy against the political and religious institutions of his country". ${ }^{39}$ Grote's teacher, on the other

\footnotetext{
${ }^{36}$ Personal Life, p. 21.

${ }^{37}$ Ibid., p. 22.
}

${ }^{38}$ Grote's remarks on the ancient polytheistic religion show that he took to heart James Mill's anti-clericalism. "The great advantage, or rather the smaller injurious tendency, in Polytheism as compared with monotheism is, that the priesthood of many Gods cannot be brought into such efficient cooperation as the priesthood of one. They cannot obtain as a body so much influence over the human mind" (BL Add. MS 29,517 (1826-1832), fo. 15). The Philosophic Radicals, Mrs Grote maintained, "naturally lent themselves to a project tending to separate education from the management of the clerical body" (Personal Life, p. 56). On James Mill's anticlericalism see Ian Cumming, "Enemies to wonder: James Mill and the Diffusionists", Paedagogica Historica, 2(1971):354.

${ }^{39}$ So W.Smith lamented in his "George Grote", p.106. 
hand, held the best idea for his development and potential, a fact emphasized by Alexander Bain whose Biography of James Mill contains a letter to Napier (3 January 1821). The young City banker is represented as "a very extraordinary person ... both for knowledge and clear vigorous thinking". 40

Robert Fenn has recently made available many details about James Mill and his political philosophy, and underlined Mill's "constant urging and guidance".41 Earlier Benn, who appreciated highly James Mill's accomplishments, regarded Grote and John Stuart Mill as his two celebrated pupils, who had been educated in the spirit of Hume's philosophy combined with Benthamism, "thus preserving the tradition of eighteenth-century thought as against the transcendentalism of Coleridge, and the reactionary spiritualism of Sir William Hamilton". ${ }^{42}$

Our best source of James Mill's keen interest in the ancients is his son's Autobiography. It is indeed to be regretted that Mill left behind him but few references to the Greeks, and only two articles - in fact criticisms of Taylor's and Sy denham's The Works of Plato. ${ }^{43}$ It is for this reason that historians of philosophy usually neglect to exhibit in its strength this slightly known side of his intellectual life. Benn however insisted on Mill's "Hellenising tendency";4 Mill approached with

${ }^{40}$ Bain, James Mill, p. 193. James Mill recommended to Macvey Napier the essay "On Magick", written by Grote, for insertion in the Encyclopaedia Britannica.

${ }^{41}$ See Fenn, James Mill's Political Thought, New York and London 1987, p. 111.

42 A.W.Benn, The History of English Rationalism in the Nineteenth Century, London 1906, vol. I, p. 418.

${ }^{43}$ T.Taylor and F.Syndenham (trans. and ed.), The Works of Plato in 5 vols, London 1804.

44 Benn, History of English Rationalism, pp. 293-5. Similarly Jenkyns, The Victorians and Ancient Greece, p. 233, points out that "James Mill was a radical, but 
enthusiasm the ancients, devoted himself especially to Plato's works, and sought to rediscover the ethical spirit of classical antiquity. In Greece, "notwithstanding the defects of Democracy", wrote Mill in his Essay on Government, "human nature ran a more brilliant career than it has ever done in any other age or country". ${ }^{45}$ Mill, in Benn's judgement, succeeded in associating utilitarianism with classic humanism, and "brought with him an appreciation of the true spirit of Hellenism as a moral force, a power making for righteousness, unknown to ... earlier scholars" ${ }^{46}$ According to the same writer Grote was imbued with the same passion for Hellenism. The Platonis Opera appears several times in the list of Mill's general reading (while a student at Edinburgh University) ${ }^{47}$ Leslie Stephen similarly pointed out Mill's interest in Plato, ${ }^{48}$ and Fenn went on to specify some 'signs' of "Mill's Platonism". ${ }^{49}$ The fact that he considered applying for the Greek Chair at Glasgow in 1818 is further evidence of his being highly qualified in this field of studies, as he was equally in many others. ${ }^{50}$

The impressive course of John Stuart Mill's early education is indicative of his

this did not lead him to reject the lessons of Greece" (Platonic philosophy included).

${ }^{45}$ James Mill, An Essay on Government (ed. E.Barker), Cambridge 1937, p. 16.

${ }^{46}$ Benn, History of English Rationalism, p. 295.

${ }^{47}$ See the list in Bain, James Mill, pp. 18-9. See further, Ian Cumming, "The Scottish Education of James Mill", History of Education Quarterly, 2(1962):162-3; and H.O.Pappe, "The English Utilitarians and Athenian Democracy", in R.R.Bolgar (ed.) Classical Influences on Western Thought A.D. 1650-1870, Cambridge 1979, pp. 295-6.

${ }^{48}$ Stephen, The English Utilitarians, London 1900, vol. II (James Mill), p. 3.

${ }^{49}$ Fenn, James Mill's Political Thought, p. 79.

${ }^{50}$ For the event see, Bain, James Mill, p. 166. Mill's linguistic criticism of Taylor's translation of Plato in the Literary Journal (see below) affords sufficient evidence of his remarkable competence in ancient Greek. 
father's intellectual tastes. Herodotus, Xenophon, Isocrates and especially Plato were the favourable figures included in John's curriculum. J.S.Mill was encouraged to read the Theaetetus at the age of seven, and he was still a child when he read the Gorgias, the Protagoras, and the Republic.51 "There is no author", J.S.Mill remarked, "to whom my father thought himself more indebted for his own mental culture, than Plato...".52 James Mill must have made frequent use of ancient thought to impart moral discipline, and impress upon his 'pupils' the model of ideal excellence; to this purpose he would have tried to inspire a deep respect for the character of Socrates and Platonic moral standards. He himself believed that Plato's precious remains "afford so remarkable a specimen of genius and eloquence ... [which] are so much adapted to sharpen the ingenuity of youth, and engender the love of science and of virtue"..53 Grote similarly, in an early "Essay on ancient and modern Education", praised ancient educational patterns as proposed by Plato and Aristotle.

The education set on foot both by Aristotle and Plato would not fail to communicate to the citizen a powerful and earnest love of his commonwealth and of all his fellow citizens. That of Plato would also impart considerable logical powers and much strengthen the intellect... $^{54}$

James Mill, as J.S.Mill informed us, believed in the moral force of Prodicus' lesson,

51 J.S. Mill, Autobiography, pp. 5-6, 9, 14-5. In Pappe's view both Mills were Platonists. "Both contributed to Plato scholarship; both followed in his footsteps in thought and action" ("The English Utilitarians and Athenian Democracy", p. 296).

52 J.S.Mill, Autobiography, p. 14.

53 James Mill, "Taylor's translation of Plato", Literary Journal, 3(1804):449.

${ }^{54}$ BL Add. MS 29,529 (1818-1822), fo. 29 (my emphasis). 
namely the 'choice of Hercules' ${ }^{55}$ It appears incontestably that James Mill held the Socratic method in great esteem, as an unsurpassed discipline for resolving the confusions in the mind.

James Mill's ardent devotion to the ancients was a lifelong distinctive characteristic of his intellectual life. For him temperance or sophrosyne, in the allinclusive sense pointed to by the Greek philosophers was the central educational objective. ${ }^{56}$ It was not a single 'academic' interest that pushed James Mill to Greek studies, but interests deeply rooted in the way he approached life and education. ${ }^{57}$ His turning to the ancients was a vital step in the process of his self-realization. In his view of life James Mill, according to his son's testimony, "partook of the character of the Stoic, the Epicurean, and the Cynic, not in the modern but the ancient sense of the word". ${ }^{58}$ His character resembled that of the Stoics, whereas in morals his adoption of Utility as the ultimate standard made him an Epicurean. Pleasure, however, as the end of right action, though of instrumental value to the construction of his theoretical schemes, had no effect upon his personal life. He set little value

55 Autobiography, p. 47. This well known fable is to be found in Xenophon's Memorabilia, II.1.21-34.

${ }^{56}$ See W.H.Burston, James Mill on Education, Cambridge 1969, pp. 8-9, 33. For Mill's thorough education in the ancients see particularly pp. 1-2, 35.

${ }^{57}$ Grote was interested in education 'for all', in the footsteps of James Mill. Grote argued vigorously against those who asserted that education for all would be mischievous for the interests of society on the ground that "the blind follows more easily the right command". "The very best and most universal system of instruction would still leave a great disparity in the intellectual endowments of individuals ... There would still be leaders and followers; but the followers would be better enabled to select the right leaders." See University of London Library, MSS 429/3 (1817), fo. 308; similarly fo. 148, and BL Add. MS 29,529 (1818-1822), fo. 36.

58 J.S.Mill, Autobiography, p. 30. 
upon pleasures, and thereby he partook of the Cynic element as well.

It is therefore acknowledged by commentators, as well as by J.S.Mill, that James Mill had an extensive intimacy with the Greeks, and especially with Plato, whose influence - "strange as it may seem" as Bower admitted ${ }^{59}$ - can be traced to the method, and not rarely to the tone of his philosophy. ${ }^{60}$ It is furthermore argued that in so far as Grote received James Mill's influence and instruction, he could not but follow the path already prescribed for him. Thus Clarke asserts that even though we hold no direct evidence, Grote's interest in Plato "and his attitude towards him no doubt derived from James Mill". ${ }^{61}$ In addition, Robertson and Mitchell, as well as Fenn more recently, assumed that the external prompting in the prospect of composing the history of Greece came from James Mill. ${ }^{62}$ Mrs Grote's assertion, according to these writers, that she first suggested the History ${ }^{63}$ is rejected, since in the Posthumous Papers is shown clearly that the book was already in preparation prior to the autumn of 1823 , i.e., in 1822 at the latest. ${ }^{64}$ Yet, this point is not easy to

${ }^{59}$ G.S.Bower, Hartley and James Mill, London 1881, p. 11.

${ }^{60}$ W.Thomas believes that Mill's ethics are Platonic in character "and lead to the paternalism of an educated class" (The Philosophic Radicals, Nine Studies in Theory and Practice 1817-1841, Oxford 1979, p. 132).

${ }^{61}$ Clarke, George Grote, p. 135, emphasis added.

62 J.M.Mitchell, "George Grote", Encyclopaedia Britannica, 11th edn, Cambridge 1910, vol. XII, p. 619; Robertson, "George Grote", p. 286; Fenn, James Mill's Political Thought, p. 111. Peter Spahn believes that the writing of a history of Greece was suggested by the 'utilitarian society'. See "George Grote, John Stuart Mill und die antike Demokratie", in Der Klassische Utilitarismus (ed. U.Gahde and W.H.Schrader), Berlin 1992, p. 146.

${ }^{63}$ For Mrs Grote's assertion, see Personal Life, p. 49.

${ }^{64}$ H.Grote (ed.) Posthumous Papers, London 1874, pp. 22-4. 
determine with certainty. ${ }^{65}$ Grote's manuscripts show that he was engaged in a detailed examination of ancient sources before $1823,{ }^{66}$ though this is not sufficient evidence to disprove Mrs Grote's assertion that she first suggested the History to her husband. Grote might have collected all this material simply to satisfy his historical curiosity. His earliest manuscript notes reveal a remarkable interest in Roman history, ${ }^{67}$ and it may not be mistaken to suppose that he first contemplated the writing of the history of Rome - a plan which was dropped at the suggestion of Norman. ${ }^{68}$

The influence of Mill on Grote was constant throughout his life, unlike J.S.Mill who subsequently moved away from his guidance. As stated in the beginning, Grote's interests at an early age inclined towards the Greek poets. He had a delicate, quite sensitive and imaginative character, that soon brought him into the domain of literature and poetry. Thus Mrs Grote complained that James Mill put limits on and "narrowed" Grote's thought, ${ }^{69}$ sacrificing his imagination and poetic inspiration (Grote composed

\footnotetext{
${ }^{65}$ L.A.Tollemache, who had personally interviewed Grote early in 1862 , offered testimony which turns against Mrs Grote assertion. See, Safe Studies, London 1895, p. 144. Lady Eastlake however, believed that it was Mrs Grote "who had originally prompted him to undertake the History of Greece" (Mrs Grote. A Sketch, London 1880 , p. 74).

${ }^{66}$ See for instance, University of London Library, MSS 429/4 (1820), and BL Add. MS 29,515 (1818-1824). These volumes contain extensive notes on the ancients, extracts from various sources (Diodorus, Pausanias, Herodotus, Plutarch, Aristotle, Thucydides, Isocrates, etc), and on several subjects (ancient law, finances, slavery, education, poetry).

${ }^{67}$ BL Add. MS 29,525 (1815-17).

${ }^{68}$ This is what Boase suggested, in his "Norman, George Warde", p. 112.

69 J.S.Mill in a letter to Carlyle in 1833 (quoted in Thomas, The Philosophic Radicals, p. 411) characterized Grote as narrow-minded. Thomas wrongly represents Mill's portrait as "accurate and penetrating"; it had been rather Mill's early opinion,
} 
poems when young, published for private circulation after his death, in 1872) to rigid and unimaginative intellect. $^{70}$ "Whereas John Mill's thought was constantly developing", wrote Clarke, "Grote's remained where it was in the eighteentwenties". ${ }^{71}$ Clarke, however, is wrong in claiming that Grote 'remained in the past'. One may discern an apparent shift in emphasis (placed on certain ideas), when the History and Plato are compared. Like J.S.Mill, or under his influence (and most importantly due to the failure of the political plans of the Philosophic Radicals), Grote advanced to a more inclusive idea of individual liberty, as compared to the classical utilitarian individualism of Bentham. He remained, of course, constantly faithful to the principles of Utility, which shaped some of his most distinguishing criticisms of Plato's dogmatic pieces. $^{72}$

Grote's 'guidance' by James Mill is not to be overrated. As John Owen rightly remarked, Grote's acquaintance with Mill was not the turning-point of Grote's life, but the completion of it. "The intellectual path already chalked out by himself now becomes broad and well defined. The keen, inquiring character of his mind receives

which he definitely modified in light of Grote's achievement. Thomas neglects that Mill in his mature years of the Autobiography described Grote as "a man of ... high intellectual and moral eminence which his life and writings have since manifested to the world" (p. 46). J.S.Mill firmly believed that Grote was unfit, due to his timid character, to take the lead of the Radicals - and he might have been right. See Alan Ryan, J.S.Mill, London and Boston 1974, p. 44. But Grote's political career and Mill's idea of it, should not be confounded with his intellectual achievement, which Mill particularly admired.

${ }^{70}$ Lady Eastlake, Mrs Grote, p. 43; discussed in Clarke, George Grote, p. 185.

${ }^{71}$ Clarke, Ibid., p. 185.

72 W.Smith emphasized Grote's lifelong adherence to the "Experience school of Intellectual Philosophy, and to the principle of Utility as the basis of Ethics. Never for one moment did he falter in his avowal of these views" ("George Grote", p. 131). 
a new and powerful impetus." ${ }^{73}$ Grote borrowed from Mill chiefly the rules of the empirical school, as for instance "The resolution to keep to solid facts ...; the attempt to treat all problems by a scientific method ..., and the contempt for the mystical and the sentimental". ${ }^{74}$ In other words Grote appropriated to himself the rigid empirical method of dealing with scientific phenomena, but developed, and employed with outstanding success this method in a field then uncultivated. Bain characterized Grote's representation of the negative function of Plato's thought, as having "the air of a discovery". ${ }^{75}$ Cope judged Grote's Plato as "the inauguration of a new era of Platonic criticism". ${ }^{76}$ Sidgwick declared the 67 th chapter of Grote's History (in which he gave an account of the sophists) to be an "historical discovery of the highest order". ${ }^{77}$ Gomperz praised Grote for coining the division between the "positive and the negative arm" of Platonic philosophy. ${ }^{78}$ Maurice in discussing the sophistic teaching referred to Grote's "able arguments and undoubted facts" that "must affect the whole course of our after history". ${ }^{79}$ And Campbell similarly pointed to Grote's

${ }^{73}$ J.Owen, "George Grote", Theological Review, 10(1873):508; similarly, Bain, 'Introduction' in G.Grote's Fragments on Ethical Subjects (ed. A.Bain), London 1876, pp. iii-iv; and Minor Works, p. [9]: Grote, Bain argued, "had thoroughly imbibed the method and views of James Mill, which he developed by resources peculiar to himself".

${ }^{74}$ L.Stephen, "James Mill", D.N.B., London 1894, vol. XXXVII, p. 388.

75 A.Bain, "Grote's Plato. The negative, or Search Dialogues", Macmillan's Magazine, 12(1865):194, emphasis added.

${ }^{76}$ E.M.Cope, Plato's 'Theaetetus' and Mr Grote's Criticisms, London 1866, p. 6.

${ }^{77}$ H.Sidgwick, "The Sophists", in Lectures on the Philosophy of Kant, London 1905 , p. 323.

\footnotetext{
${ }^{78}$ T.Gomperz, Greek Thinkers, London 1905, vol.II, p. 104.

${ }^{79}$ F.D.Maurice, Moral and Metaphysical Philosophy, London 1882, vol. I, p. 117.
} 
novelty and outstanding insight into Greek history. Grote brought out "some features which would otherwise have remained in shadow". ${ }^{80}$ The novelty of Grote's interpretation of Plato and the sophists was generally recognized, yet, it is useful to examine James Mill's brief pieces on Plato, and point out whatever similarities in approach might exist.

Mill criticized Taylor's work on Plato in two articles published in 1804 and 1809 respectively. It had been the fate of Plato, Mill argued, to be seen through the allegorizing theories of those "charlatans" of ancient philosophy, the Alexandrian thinkers. Thus even in modern times, Mill proceeded, Plato's philosophy is blended with an audacious spirit of mysticism and irrationality. ${ }^{81}$ Plato has come down to us, Mill remarked, in a thoroughly mutilated condition, and of course he stood in need of being reviewed. The Neo-platonists present Plato as the most affirmative of all human beings whereas "One of the most remarkable features of the writings of Plato is, that he affirms nothing". ${ }^{82}$ Plato, according to James Mill, "adhered to the rule of his master [Socrates]; played with the theories of others, and advanced nothing seriously himself" ${ }^{83}$

Plato's fundamental objective in Mill's judgement was to encourage

\footnotetext{
${ }^{80}$ Lewis Campbell, The 'Theaetetus' of Plato, Oxford 1883, p. viii.

81 James Mill, "Taylor's Plato", Edinburgh Review, 14(1809):191-3; "Taylor's translation of Plato", p. 454. Similarly Edward Gibbon had been no less critical of the Neo-platonic exegesis. See Decline and Fall of the Roman Empire, London 1895, vol. III, p. 77. On Taylor's work and its influence see M.L.Clarke, Greek Studies in England: 1700-1830, Cambridge 1945, p. 119; and E.M.Mannase, "Platonism since the Enlightenment", Dictionary of the History of Ideas, New York 1973, vol. III, p. 519.
}

82 "Taylor's Plato", p. 199, emphasis added.

83 "Taylor's translation of Plato", p. 453. 
speculation, to give specimens of investigation, to make his students capable of discerning and exposing fallacies, "rather than lay down and establish any system of opinions" ${ }^{84}$ It appears that Grote may have been indebted to Mill as regards the high appreciation of the 'Socratic Plato', or the negative Plato. Yet we are surprised to find that James Mill disputed the affirmative purpose even of such compositions as the Phaedo, Republic and the Laws. ${ }^{85}$ The chief object of these dialogues, was, in Mill's view, inquiry per se; these works are too far from establishing any system or any doctrine. Thus Mill, at least in the limited space which he reserved for Plato, did not distinguish between the dialogues of search and those of exposition: the negative and the affirmative. Disregarding this distinction Mill identified the philosophy of Plato with that of Socrates. He seems not to have acknowledged a dogmatic side of Platonic philosophy. ${ }^{86}$ Plato's primary business, as understood by Mill was to emphasize the rule of reason and to stimulate the students' interest in disinterested enquiry. Grote, as we shall see, departed from his master's view, and dwelt on the distinction between the negative and the affirmative Plato. In the negative dialogues Plato is a legitimate philosophical researcher, whereas in the positive dialogues research as such is cast aside: the master is occupied with elaborating his unique principles, which are not susceptible to rational demonstration, nor could have stood for a second the Socratic cross-examination. Mill also seems to have shared in the traditional belief which

\footnotetext{
84 "Taylor's Plato", p. 199.

${ }^{85}$ The arguments in the Phaedo, in Mill's view, are not to be taken as seriously intended by Plato; see "Taylor's translation of Plato", p. 453. Similarly Plato's business in the Rep. and the Laws is "to give specimens of investigation, to let in rays of light, to analyze particular points ... rather than lay down and establish any system of opinions" ("Taylor's Plato", p. 199).

${ }^{86}$ See "Taylor's translation of Plato", p. 452.
} 
portrayed the sophists as pretenders to knowledge, who covered their ignorance by teaching eloquence. These men, he argued, "filled the minds of the youth with a spirit of mere logomachy, and with the worst impressions of right and wrong, with regard both to public and to private life". 87

As committed to utilitarianism Grote had also adopted from Mill the theory of Association. In reviewing the Meno Grote openly criticized Plato in the light of the theory of association. Plato defended the Pythagorean doctrine of pre-natal experience and cognitions, simply because he took no account of the diversity of experiences and comparisons perpetually operative in the mind. If Plato, Grote argued, had taken pains to study the early life of the untaught slave, "with its stock of facts, judgments, comparisons, and inferences suggested by analogy ... he might easily have found enough to explain the competence of the slave to answer the questions appearing in the dialogue".88

The Association-theory is furthermore put forward as the clue for the solution to the problem of magic. ${ }^{89}$ The belief in magical powers, Grote argued, takes its rise when

Unimportant phenomena are connected in our imaginations with a particular result, merely because they happen to precede it in the order of time and thus become invested with that excessive and unwarranted range of agency, which if not detected and verified by subsequent 451,453 .

${ }^{87}$ See "Taylor's Plato", p. 199; similarly, "Taylor's translation of Plato", pp.

${ }^{88}$ Plato, 2:22. Cf. 1:523, where Grote ascribed to Plato a good part of the theory of Association.

${ }^{89}$ Grote in his various notes on Metaphysics endorsed the theory of Association. See BL Add. MS 29,528 (1818-1822), fos. 46, 85. See Grote's notes on Hartley in BL Add. MS 29,514 (1818-1831), fo. 327. 
observation, falls afterwards under the denomination of Magick..$^{90}$

Grote's essay "On Magick", written in 1820, bears the unmistakable signs of influence by Mill, as well as by Bentham.

Mill's debt to Hartley is well known. Stephen regarded Hartley as his "chief master", whose theory he applied extensively, and even advanced further. ${ }^{91}$ Stephen also referred to Mill's 'Baconian' principles, and his ardent belief in the philosophical effectiveness of the inductive method. (Grote similarly referred to Bacon's Novum Organum several times, and he identified the Socratic method with the inductive process of Baconian spirit. ${ }^{92}$ ) James Mill considered Hartley's Observations on Man as we are informed by his son -, the "really master-production in the philosophy of mind. ${ }^{193}$ Subsequently Mill, in the Analysis, extended the principle of Association; it was, John Stuart believed, one of his most important contributions to psychology. Following his principles he envisioned the moral improvement and intellectual condition of mankind by means of education. ${ }^{94}$ As Bower pointed out, Mill deemed the value of education to be depended on the building up of associative links between

\footnotetext{
${ }^{90}$ BL Add. MS 29,531, fos. 9-10.
}

${ }^{91}$ Stephen, "James Mill", p. 388; see also, The English Utilitarians, vol. II, pp. 288-9, 292-3. For an extensive discussion on Mill and Hartley see Fenn, James Mill's Political Thought, pp. 34-46.

${ }^{92}$ Grote, History, 7:126-129. See also, BL Add. MS 29,528 (1818-1822), fo. 38: Bacon, according to Grote "gave to the human intellect light to see by, and tools to dig with", etc. In one of his poems, which he composed when very young, Grote alluded to Lord Bacon, as the founder of experimental philosophy: "... he, the British Genius, sent his light/ O'er the long track of Lethargy and Night" (Poems, printed for private circulation, London 1872, p. 19).

\footnotetext{
${ }^{93}$ Autobiography, p. 43.

${ }^{94}$ Ibid., pp. 65-6.
} 
actions advantageous to the greatest number (or disadvantageous), and pleasurable (or painful) ideas. ${ }^{95}$

Thus Grote appears to have early in his life come under the influence - and within limits, under the supervision - of James Mill. It should be pointed out that Grote's pamphlet The Essentials of Parliamentary Reform was written in 1831 at the request of James Mill. ${ }^{96}$ The political views expressed in the pamphlet, and the reformatory spirit which permeated its main propositions were unquestionably favoured in Bentham's circle. Grote criticized the idea of class representation and defended a representative system which included one million voters. Such a system would not have neglected the "interest and well-being of the middling classes", and would "purify the Government, thoroughly, at once and for ever, of that deep and inveterate oligarchical taint which now infects it in every branch". ${ }^{97}$ Grote, from the time of his acquaintance with James Mill and onwards, remained faithful to the old utilitarian principles - a fact not only shown by his various arguments in the Plato and his ethical papers (published in 1876), ${ }^{98}$ but moreover by his lifelong occupation with

\footnotetext{
${ }^{95}$ Bower, Hartley and James Mill, p. 183.

96 Robertson, "George Grote", p. 287; H.Grote, Personal Life, pp. 66-7. The pamphlet was reprinted in Minor Works, pp. 1-55. Thomas, The Philosophic Radicals, p. 128, remarks that the pamphlet was the first reply to Mackintosh's attack on Bentham. See further Bain's analysis, Minor Works, pp. [1]-[9]. The fact that he was urged to write the Essentials by Mill, Clarke remarks, "is an indication of the position he had won for himself as political theorist and propagandist of the Philosophical Radicals" (George Grote, p. 38).

97 "Essentials of Parliamentary Reform", Minor Works, p. 24. On the 'middling citizens', whose interests James Mill particularly vindicated, and their influence in promoting stability in the Greek democracies, see BL Add. MS 29,514 (1818-1831), fo. 192 .

${ }^{98}$ Clarke remarks that when his ethical papers finally published in 1876 , "they probably seemed like a voice from the past, as indeed they were" (George Grote, p.
} 
the management of University College and the University of London. ${ }^{99}$ Grote was early induced to embrace the philosophy of Utility, and as a consequence to adopt its scientific methods, which shaped the structure and argumentation of his main works, the History, the Plato, and his unfinished last undertaking, the Aristotle. Features such as an insistence on the importance of facts, empirical categorization of particulars, rejection of vague apriorism, accurate argumentation unaffected and unbiased by conventional beliefs, abstention from endorsing metaphysical thought, etc., were developed in conformity with the intellectual ideas of Utilitarianism. Grote was called to work in a thoroughly rationalistic atmosphere, and to accept its strict logical standards. It was not accidental of course that he soon became an atheist. ${ }^{100}$

James Mill, no doubt, provided Grote with an essential intellectual stimulus and enhanced his interest in the ancients. Further he introduced him to the utilitarian circle, and familiarized him with the empirical method of philosophic investigation. It should be noted, however, that Grote was much earlier interested in the Scottish philosophers, like Hume and Adam Smith. Obviously Grote met James Mill in 1819 since he himself sought his instruction and friendship. It is worth observing that Grote

134).

${ }^{99}$ Stephen, The English Utilitarians, vol. III (J.S.Mill), p. 337. Clarke deals with Grote's activity in University education in George Grote, pp. 150-171.

${ }^{100}$ Benn, History of English Rationalism, vol.I, p. 295; Clarke, George Grote, pp. 20-21 and 180-81. Grote, according to a writer in the Christian Observer ("Life of George Grote", 73(1873):636), became irreligious and indifferent to sensitivity due to the influence of James Mill, and Bentham, who is called a "dreamy, speculative philosopher". In his "Logical and Metaphysical Essays" Grote rejected the idea of a supernatural "Creator". See, BL Add. MS 29,528 (1818-1822), fos. 98-9. The word "immaterial Being is in reality as great a contradiction as a non-existent Being" (BL Add. MS 29,523 (Before 1826), fo. 5). 
was at any rate so timid and moderate a person, ${ }^{101}$ that he could believe himself 'guided', though without any longer sufficient justification. As Macllwraith remarked "no man was ever so unconscious of his own greatness". ${ }^{102}$ In 1845 for instance, he expressed to his wife his fears that no bookseller would be willing to face the risk of printing his History. Mrs Grote, an energetic and powerful personality, ${ }^{103}$ made immediately all the arrangements with Murray. When Grote became aware of this he observed: "I only hope that the poor man will not be a loser by me, and then I shall be content, come what may." A few years later, Grote, writing to J.S.Mill, expressed his doubt whether his Plato could expect many readers, "as for approving readers, they will be few indeed". ${ }^{104}$ It is well known that both works were welcomed among scholars, and they were recommended as standard text-books. Murray was content to publish them several times.

James Mill was partly responsible for the orientation of Grote's studies. But as to the content of these studies, the remarkable connection of facts, and the copious

101 See the anecdotes given by Lady Eastlake, Mrs Grote, pp. 45-7. Grote, according to Thomas, "had a much stronger tendency to retire into his shell, to despond, to take opposition as an excuse to retire from the fray" (Philosophic Radicals, p. 413).

${ }^{102}$ W.Macllwraith, The Life and Writings of George Grote, London 1885, p. 7, 17.

${ }^{103}$ According to T.H.Lewin (ed.) The Lewin Letters, London 1909, vol. I, p. 148, Mrs Grote "was strong and high-spirited when young, being known in her own family as 'the Empress' from her imperious disposition"; similarly Lady Eastlake, Mrs Grote, p. 5. See also Clarke, George Grote, p. 25; and Thomas, Philosophic Radicals, p. 414. Cobden wrote in his diary of June 1837: "I was yesterday introduced to Mrs and $\mathrm{Mr}$ Grote at their house. I use the words Mrs and Mr Grote because she is the greater politician of the two. He is a mild and philosophical man, possessing the highest order of moral and intellectual endowments, but wanting something, which for need of a better phrase, I shall call devil" (quoted in John Morley, The Life of Richard Cobden, London 1881, vol. I, pp. 136-7).

${ }^{104}$ Personal Life, p. 161 and 263 for the letter to J.S.Mill (Dec. 1862). 
extraction of original inferences, Grote was himself alone responsible. Grote, the classicist, is to a great extent original; and this side of his personal history has been overlooked by many historians, inasmuch as they tended to look at him solely as a faithful disciple of the principles of Utility, and of their chief representatives. Mill, nevertheless, due to their close relationship, surely deserves to be credited with the greatest part of stimulus and influence. ${ }^{105}$

\section{III}

\section{A Lifelong Relationship with J.S.Mill}

It was not one-sided influence that connected J.S.Mill and Grote. Each one had a direct influence on the other. ${ }^{106}$ Mill's works, and especially the System of Logic and On Liberty impressed Grote, who often praised them throughout his writings. On the other hand Mill, as far as his interpretation of Plato is concerned, became influential, as Levi puts it, "through Grote". ${ }^{107}$ Grote was a classical scholar and historian, whereas Mill was more of a philosopher of Logic and Politics. Yet, Stephen's statement that Grote "was more of a Millite than Mill", ${ }^{108}$ with reference to J.S.Mill, is a useful exaggeration, since it underlines Grote's lifelong commitment

105 See also, P.Anton, Masters in History. Gibbon, Grote, Macaulay, Motley, Edinburgh 1880, p. 72, and pp. 89-90.

${ }^{106}$ H.O.Pappe mentions Grote as one of Mill's mentors. See "The English Utilitarians and Athenian democracy", p. 302. "Him I often visited", wrote J.S.Mill about Grote in his Autobiography, "and my conversations with him on political, moral, and philosophical subjects gave me, ... much valuable instruction" (p. 46).

${ }^{107}$ A.W.Levi, "The Idea of Socrates: The Philosophic Hero in the Nineteenth Century", Journal of the History of Ideas, 17(1956):91.

${ }^{108}$ Stephen, The English Utilitarians, vol. III, p. 337. 
to the philosophic leader of later utilitarianism. The two men were sincere friends throughout their life; a friendship unaffected even by Mill's seclusion, in which he resolved to subject himself by reason of his devotion to Mrs Taylor. They preserved their relations despite Mrs Grote's apparent disapproval. ${ }^{109}$ Mill broke off all relations with Mrs Grote, and they were not to be re-established until after his wife's death. ${ }^{110}$ In reviewing Grote's Aristotle, which was published posthumously, Mill paid tribute to him, and declared his regret for his 'premature' death. ${ }^{111}$

Grote had already paid his tribute to Mill. He compared the youthful Mill with the young and immature Theaetetus, and James Mill with the Platonic Socrates who applied the vigorous process of dialectic. ${ }^{112}$ It was not surprising to Grote, that after this sort of discipline had taken place, J.S.Mill surpassed his father. In the same piece of work Grote proceeded to a eulogy of Mill's essay On Liberty. ${ }^{113}$ Mill and Grote approached Socrates as the conductor of critical epistemology, who replaced the authority of the commonplace with the sovereignty of undisguised intellect. ${ }^{114}$

\footnotetext{
${ }^{109}$ Stephen, English Utilitarians, vol. II, pp. 44 and 337; Ryan, J.S.Mill, pp. 12-13; R.Borchard, John Stuart Mill: the Man, London 1957, p. 62.

${ }^{110}$ Clarke, George Grote, pp. 68-9 and 86-7. Clarke however assumed that Grote's and Mill's relations were somewhat 'freezed'. Mrs Grote expressed herself with the utmost sorrow at the news of J.S.Mill's death. See extracts from her diary, in Lady Eastlake, Mrs Grote, pp. 145-6.

111 J.S.Mill, "Grote's Aristotle", (Fortnightly Review, 13(1873):27-50) in J.M.Robson (ed.) Collected Works of John Stuart Mill (thereafter C.W.) 1978, vol. XI, p. 475. 284-5.

112 "Review of J.S.Mill on the Philosophy of Sir W.Hamilton", Minor Works, pp.

${ }^{113}$ Minor Works, p. 288. See also Personal Life, p. 278 (letter to J.S.Mill).

${ }^{114}$ F.M.Turner, The Greek Heritage in Victorian Britain, New Haven and London 1981, p. 303.
} 
Biographical material will not be cited here. It suffices to recollect that John Stuart Mill passed through an almost exhaustive course of study of classical literature, but like his father he left no coherent or systematic work on the ancients. Yet the few sources we possess, as well as some hints regularly found in his general philosophical compositions, suggest his crystallized views. Mill's suggestions are related to two great aspects of the ancient Greek world: Plato's philosophy and the Athenian democracy. ${ }^{115}$ Mill, however, did not believe that his points of view could formulate an intellectual outline, new and rather different from the scheme already proposed by Grote. In a letter to Grote (11 March 1865) he confessed that the Plato "completely fulfils my hopes ... Your general conception of Plato ... seems to me completely inexpugnable". ${ }^{116}$ In a subsequent letter to the historian, on the occasion of his reviewing the Plato, he admitted: "I meant ... not that I had attained any higher point of view than yours, but that I hoped to reproduce yours in a condensed form." 117 Indeed his review was an eloquent, shortened outline of Grote's work. ${ }^{118}$

According to Borchardt the fact that Mill reviewed Grote's History of Greece (we may add the reviews of Plato and Aristotle), combined with the value Grote attached to his criticisms, ${ }^{119}$ are sufficient proof of "J.S.Mill's proficiency in yet

${ }^{115}$ F.E.Sparshott, "Introduction" to Collected Works, vol. XI, p. xvii.

${ }^{116} C . W$. , vol. XVI (The Later Letters of J.S.Mill, 1849-1873), ed. F.E.Mineka and D.N.Lindley, 1972, p. 1010.

${ }^{117}$ Personal Life, p. 276. See also Mill's C.W., vol. XVI, pp.1120, 1160 (letters addressed to Grote, dated 26 Nov. 1865 and 22 April 1866 respectively).

${ }^{118}$ Mill disagreed however with Grote in his interpretation of the Protagorean doctrine Homo Mensura.

${ }^{119}$ See Personal Life, p. 263. Grote was writing to Mill - after the latter's decision to review the Plato: "It will be an additional incentive to my industry now that I learn 
another field, in addition to those in which we are used to considering him an authority". ${ }^{120}$ It is worth mentioning that as a preparation for reviewing Grote's Plato Mill reread the entire Platonic corpus in Greek. ${ }^{121}$ In all the reviews he displayed a remarkable knowledge of the ancients, and a tendency towards the most radical revaluation of their philosophy. Bain was not right in calling Mill's knowledge of the Greeks "superficial". ${ }^{122}$ Mill had a considerable and markedly comprehensive knowledge of the ancients. Grote's main biographer, Clarke, neglects to touch on the importance Mill's judgement had for the historian; for apart from personal gratification it was a well-defined reconfirmation of the validity of his central arguments. Mill's belief in the significance of Grote's works was never to be gainsaid.

Let us turn now to the few pieces published between 1834 and 1835 in the Monthly Repository, and a small number of others recently published from Mill's manuscripts. ${ }^{123}$ We possess nine commentary-translations from which only four appeared in the M.R. Those published are fragmentary translations of the Protagoras, Phaedrus, Gorgias, and the Apology; the Apology being entirely translated. Those firstly published from Mill's manuscripts are the Charmides, Euthyphron, Laches, Lysis, and the Parmenides. Mill himself in his Autobiography mentioned that these

your obliging intention to review the book in 'Edinburgh Review'. That will be a genuine service to the work, as well as a compliment to myself."

${ }^{120}$ Borchardt (ed.) Four Dialogues of Plato (trans. with notes by J.S.Mill), p. 23.

${ }^{121}$ A.Bain, John Stuart Mill: A Criticism With Personal Recollections, London 1882 , p. 125.

122 Ibid., pp. 24-5. However, elsewhere he characterized him as a "Greekintoxicated man" (p. 94).

${ }^{123}$ See C.W., vol. XI, pp. 175-238. 
abstracts with introductory remarks, though unpublished until 1834 , had been written several years earlier. ${ }^{124}$

Mill's opening comments on the Protagoras are much the same as his father's twenty years earlier, in his critique of Taylor's Plato. Mill expressed his regret that, by that time, there were in England no deserving commentaries that could facilitate the study of "the most gifted of Greek writers". ${ }^{125}$ Instead of this, those who designated themselves 'Platonists' had "manufactured"126 a number of peculiar philosophic systems, contending that they are genuinely Platonic. Yet, in effect, these diverse systems were unwarrantably deduced from detached passages of the ancient text. Their arguments are totally unreliable, Mill concluded, in so far as "it is to this day a problem whether Plato had a philosophy: if he had, it certainly was not the philosophy of those who have called themselves Platonists". ${ }^{127}$ Mill in effect denied the existence of a philosophical system in Plato. In reviewing Grote's Plato he defended the existence of "two complete Platos in Plato- the Sokratist and the Dogmatist". ${ }^{128}$ Mill thus adhered only to one aspect of Plato's writings; that which is concerned with the Socratic philosophical method, and to which his father besides

${ }^{124}$ Autobiography, p. 119. M.S.J.Packe puts them after his 'crisis', at around 1826, and as intended to produce therapeutic effect. See The Life of John Stuart Mill, London 1954, p. 136. Sparshott shows, however, that they were written later than this period, and possibly in 1828; see $C . W$., vol. XI, pp. xviii-xx.

${ }^{125}$ C.W., vol. XI, p. 39. Mill excluded from his criticism the able edition of Martin Joseph Routh, Platonis Euthydemus et Gorgias, Oxford 1784.

$$
\begin{aligned}
& { }^{126} \text { C.W., vol. XI, p. } 40 . \\
& { }^{127} \text { C.W., Ibid. } \\
& { }^{128} \text { C.W., vol. XI, pp. } 40 \text { and } 415 .
\end{aligned}
$$


declared firm allegiance. ${ }^{129}$ Mill went on to endorse the remarks of the "celebrated" Schleiermacher ${ }^{130}$ on Socrates. ${ }^{131}$ Schleiermacher asserted that Socrates' philosophy is not to be estimated by the truths at which he himself arrived, but by the intellectual process he originated in seeking such truths. In Mill's judgement, Plato likewise advanced and particularized the proper mode of philosophizing, the proper course for enquiry, and the spirit in which such an enquiry should be conducted. ${ }^{132}$

In the Autobiography Mill expanded on this point. The title of a Platonist is there ascribed to those who were nourished in Plato's mode of investigation, rather than to those who propounded dogmatic conclusions by resting on the least intelligible of Plato's dialogues. These 'conclusions' might have appeared, even to Plato himself, "poetic fancies, or philosophic conjectures". ${ }^{133}$ The title fairly belongs to those who believe in the importance per se of the Socratic dialectic, which is essentially a negative process. Mill declared himself a Platonist in this sense; "I have ever felt myself, beyond any modern that I know of except my father and perhaps beyond even

${ }^{129}$ See G.L.Williams, "History and History: J.S.Mill on the Greeks", Polis, vol. IV. No. 2, 1982, pp. 9-10.

${ }^{130}$ Schleiermacher influenced both Grote and J.S.Mill. Mill called him "that great scholar and divine", and praised his "excellent dissertation" on Socrates (C.W., vol. XI, pp. 241-2). Grote adopted Schleiermacher's argument that the Platonic Apology is a close approximation to the defence which Socrates actually made. See BL Add. MS 29,522 (prior to 1832), fo. 18; see also fos. 52-62 for extensive notes on Schleiermacher's Plato.

${ }^{131}$ F.D.E. Schleiermacher, "On the Worth of Socrates as a Philosopher", trans. by Connop Thirlwall, Philological Museum, 2(1833):538-55.

${ }^{132}$ C.W., vol. XI, p. 41; similarly Grote, Plato, 1:95.

${ }^{133}$ Autobiography, p. 15. 
him, a pupil of Plato, and cast in the mould of his dialectics". ${ }^{134}$ The tendency, Mill contended in his On Liberty, was to dismiss "negative logic - that which points out weaknesses in theory or errors in practice, without establishing positive truths". ${ }^{135}$ The Socratic elenchus is the supreme means to the correction of errors that are "incident to the intellectus sibi permissus". ${ }^{136}$ It leads the mind from vague generalities to particular instances and sound definitions. ${ }^{137}$ Platonic dialectic, Mill believed, exposes ignorance and falsehood, and aids the clarification of such concepts as justice and virtue, good and evil. Though the results may be not conclusive, it does not mean that they are not highly beneficial for educative purposes. ${ }^{138}$

It suffices at present to say that Grote attached considerable value to the negative Plato. He distinguished between the sceptical and dogmatical Plato, the

134 See the The Early Draft of John Stuart Mill's "Autobiography" (ed. J.Stillinger), Urbana 1961, p. 48. J.H.Burns indicates traces of Platonic influence in Mill's politics: see "J.S.Mill and Democracy, 1829-61" (I), Political Studies, 5(1957):160, 167 See also, W.Thomas, Mill, Oxford 1985, p. 27; A.Ryan, J.S.Mill, p. 130; D.F.Thompson, John Stuart Mill and Representative Government, Princeton 1976, p. 113; and F.W.Garforth, Educative Democracy, Oxford 1980, p. 22.

${ }^{135}$ J.S.Mill, "On Liberty", C.W., vol. XVIII (1977), p. 251.; similarly Grote, Plato, 3:478, 3:485. In the System of Logic, Bk. V. I.1, Mill argued that to examine the varieties of apparent evidence (Fallacies) was among the duties of a logician.

${ }^{136}$ Autobiography, pp. 14-5. (The phrase is borrowed from Bacon, "Instauratio Magna", Novum Organum, Works, vol.I, Bk. I, pp. 138, 160; see C.W., vol. XI, p. 310, editor's note.)

${ }^{137}$ See J.S.Mill, "Inaugural Address at St.Andrews", C.W., vol. XXI (1984), pp. 229-30: "Human invention has never produced anything so valuable, in the way both of stimulation and of discipline to the inquiring intellect, as the dialectics of the ancients ... To question all things; never to turn away from any difficulty; to accept no doctrine either from ourselves or from other people without a rigid scrutiny by negative criticism, letting no fallacy, or incoherence, or confusion of thought, slip by unperceived ...; these are the lessons we learn from the ancient dialecticians."

${ }^{138}$ See Garforth, Educative Democracy, p. 11. 
philosopher and the apriorist, and he upheld the preponderance of the searching and testing dialogues over those he called expository. ${ }^{139}$ Grote regarded the dialogues of search as self-contained, and valuable in themselves. ${ }^{100} \mathrm{He}$ also believed that no ulterior or esoteric meaning is to be searched out. Grote was in agreement with Mill in holding the sort of errors that Socrates took pains to correct as incidental to the intellectus sibi permissus. The analytic mind of Socrates, and his abhorrence of dogmatism, were qualities which Grote keenly appreciated.

A first glance through Mill's pieces shows a remarkable coincidence between his and Grote's points of view. It may be argued, not unjustifiably, that Mill's abstracts constituted the abstracts of Grote's main chapters. But this sort of argument results in underestimating Grote's originality. The fact is that the main ideas here put forward by J.S.Mill were commonly shared with his father as well as with Grote. These ideas, however, never took the form of fully developed arguments, and remained for a long time as tentative proposals. Grote's contribution in this regard consisted in providing a full exploration of these ideas, in their philosophic vindication, and in the fulfilment of a task which James Mill undeniably would have considered a great one.

The Protagoras appeared to Mill an excellent and accurate illustration of "the art of investigating truth". ${ }^{141}$ The feeling that Plato did not wish to inculcate any

${ }^{139}$ Plato, 1:212-13, and 1:236.

${ }^{140}$ See John Owen, "George Grote", Theological Review, 10(1873):516-7: "To the idealistic doctrines of Plato himself, in common with all philosophers of the same school, Grote manifested undisguised repugnance." Emphasis added. Owen exaggerated a lot Grote's antipathy to Plato's dogmatism.

${ }^{141}$ C.W., vol. XI, p. 42. 
opinion or doctrine penetrates this dialogue so persuasively that it could be inferred, Mill argued, "that the author had not yet made up his opinions on the topics treated". ${ }^{142}$ Mill proceeded to a defence of the sophists. His argument in favour of the sophists was one among the first ever produced in Britain. ${ }^{143}$ According to Mill the sophists were reproached, as a rule, by those who discredited freedom of inquiry and democracy. ${ }^{144}$ Nevertheless, their reproach is historically unjustifiable since the word 'sophist' initially meant 'a teacher of wisdom'. On the other hand Plato's criticism of Protagoras, although warm, is evidently respectful. Nothing in the dialogue points to Protagoras' immorality, for the arguments Plato made him put forward were sound and useful.

There are however three significant points on which Mill and Grote differed. First, like his father, Mill spoke loosely about the sophists as a class. Secondly he took many of Plato's dialogues as purposefully designed to counteract sophistic thought. A third difference concerns more specifically the Protagoras. Mill in the first page of his Utilitarianism appeared rather convinced that the theory put forward in this dialogue, and advocated by Socrates, is the theory of Utility. ${ }^{145}$ This opinion

${ }^{142} C . W$., vol. XI, p. 43 . Grote went on in the same spirit to assert that "Plato is a searcher, and has not yet made up his own mind." When certain difficulties occurred repeatedly in Plato's dialogues, it is to be assumed that they are real and not technical or artificial. See Plato, 1:x, and 1:246.

${ }^{143}$ The first scholar who complained that the sophists' real character was generally misunderstood was John Gillies, the historian of Greece and translator of Aristotle. But his defence of the sophists was rather incidental in character. See The Orations of Lysias and Isocrates, trans. with notes, London 1778, pp. 16-7n.

${ }^{144}$ C.W., vol. XI, p. 44.

${ }^{145}$ See, "Utilitarianism", C.W., vol. X (1969), p. 205. 
Grote explicitly disclaimed. ${ }^{146}$ In Mill's Utilitarianism Grote believed that there existed an obvious discrepancy, viz., to call the doctrine of Socrates "the theory of Utilitarianism" (a doctrine which is prominently self-regarding), and to specify the standard of utilitarianism as not the greatest happiness of the agent himself alone, but the greatest amount of happiness altogether. The last disagreement would have not occurred had the two scholars understood the dialogue in exactly the same way.

Grote challenged the long-established conception respecting the sophists, as a certain class of professional teachers. ${ }^{147}$ Such a conception, namely to reduce the sophists to a class, was purposefully intended to assimilate them to a sect, a term so strongly suggestive of secret and corrupting doctrines and aims. To conservative English scholars the sophistic class or 'sect', would be understood in terms of a secular faction, or an anti-Christian heresy. Against this tendency, Grote emphasized that the sophists were persons distinguished from each other by strong individual peculiarities.

Regarding the second point of disagreement, Grote was far from believing that Plato's primary task had been to counteract the sophists, and bring evidence against them. Here again he argued that to treat Platonic philosophy in this way was highly misleading. ${ }^{148}$ Not only were they not ill-used in Plato's hands, Grote argued, but on the contrary they were represented as uttering noble and instructive judgements. Plato's practice was basically confined to a polemic against the sophists for being paid

\footnotetext{
${ }^{146}$ Plato, 2:83n. Mill however, in reviewing Grote's Plato revised the view put forward in Utilitarianism. Now Socrates is said to have maintained the doctrine of Hedonism; see $C . W$., vol. XI, p. 391.

${ }^{147}$ History, 7:53-4.

${ }^{148}$ History, 7:43. Protagoras is treated with reverence; Hippias with respect.
} 
teachers. ${ }^{149}$ Yet Plato's peculiar use of the word 'sophist', in Grote's judgement, became regrettably predominant in modern times.

Mill did not develop his arguments further, nor did he proceed to criticize Plato. His purpose in introducing these dialogues was, as he himself explained, to "allow [Plato] to speak for himself". ${ }^{150} \mathrm{He}$ did not intend, as he confessed, to suggest any judgement on the value of the opinions which are proposed in the Protagoras, mostly because some of them are apparently not Plato's own. The doctrine so emphatically defended by Socrates, "as it ever was by Epicurus or Bentham", cannot be ascribed to Plato; "it is doubtful whether he had adopted, on the subject of the original foundation of virtue, any fixed creed". ${ }^{151}$ Where Plato's opinion seems never to vary, according to Mill, is on the subject of the nature and properties of knowledge in the abstract; that is to say his constant determination to hold the inseparableness or absolute identity of knowledge and virtue. In Plato "morals are but a branch of intelligence". ${ }^{152}$ It may be affirmed, Mill argued, that this is the only ascertainable, deliberate Platonic creed. ${ }^{153}$ J.S.Mill's interpretation of Platonic

${ }^{149}$ Similarly, Gomperz (a German scholar who embraced heartily Grote's theories on the ancients, and close friend of J.S.Mill), Greek Thinkers, vol. I, p. 419, argued that Plato "delighted in jeering at the professional element in sophistry, which he considered vulgar and banal, with especial reference to the system of fees ... Modesty, as we know, was not a virtue of that age, and Plato himself, by the way, was no exception".

${ }^{150}$ C.W., vol. XI, p. 60. Thirty years later Mill would similarly argue that in Grote's pages "Plato himself, not anybody's interpretation of him, is brought before us" (Ibid., p. 383).

${ }^{151}$ C.W., vol. XI, p. 61.

${ }^{152}$ Ibid.

153 James Mill would have approved of his son's conclusion; see Borchardt's comment, Four Dialogues of Plato, pp. 10-11. 
philosophy is markedly representative of the spirit which animated the Philosophic Radicals. The identity of knowledge and virtue is in other words the association of morals with tested rationality. Though they would differ with Plato as to the springs of moral action.

In Mill's introductory remarks the Phaedrus is described as a typical exemple of Platonic philosophical inquiry. Whatever in the Phaedrus concerns methods of philosophizing is perfectly instructive, while the remainder is not to be taken too seriously; in this part "there is an appearance of sportiveness, and sometimes almost of mockery". ${ }^{154}$ The corner-stone of the Platonic logic and metaphysics is the process of comprehending general ideas, a process that embraces correct definition through analysis. It is a process which aims at arriving at knowledge of a thing by apprehending it as Many and as One. In that connection, Mill argued, a great number of philosophers, including Bacon, Locke and Kant, had in effect concurred in employing the method of philosophizing which Plato developed. ${ }^{155}$ These and other German philosophers, however, dissent from each other, in that they invest the Ideas with varying qualities: some ascribed to them objective existence, totally unconditional; some other subjective reality, existing in the mind and thus absolutely conditional. ${ }^{156}$

Mill's portrayal of Socrates depended, as in the case of Grote, on the conviction that the Platonic Apology was substantially identical with the real speech

${ }^{154}$ C.W., vol. XI, p. 62.

${ }^{155}$ C.W., vol. XI, pp. 93-4.

${ }^{156}$ Plato in the Phaedrus, in a way that amalgamates myth and reality, attributes "self existence to genera and species" (C.W., vol. XI, p. 95). 
delivered by Socrates at his trial. ${ }^{157}$ This view was earlier vindicated by Schleiermacher, and Mill as well as Grote followed his main assumptions. ${ }^{158}$ The Apology, Mill asserted, may be contrasted with "those of [Plato's] works which there is no reason to consider as having any foundation in real incidents, or conversations actually held between the supposed interlocutors". ${ }^{159}$ This point has been taken up by Grote, who persistently reminded his readers that what they read has been written by Plato, and thus there is no guarantee that he might not have imagined some points rather than carefully reported them. ${ }^{160}$

In the essay On Liberty Mill represented Socrates as a martyr for wisdom and individuality, whose teaching and action came in a "memorable collision" with public opinion and the Athenian legal authorities. ${ }^{161}$ Socrates refused to conform to the unexamined current ethical sentiment, and thereby to sacrifice his philosophical method. In Mill's eyes Socrates' destiny would have exemplified vividly the conflict between critical rationality and prejudiced commonplaces. In Socrates' destiny Grote and Mill discerned nothing mystical, religious or transcendental. The dominant interpretation, in contrast, wanted Socrates to have firmly resolved to devote his life to the moral improvement of his fellow-citizens, making it his sacred duty to

${ }^{157}$ C.W., vol. XI, p. 151. See Grote, History, 7:154; Plato, 1:281.

${ }^{158}$ Schleiermacher, "Worth of Socrates as a philosopher", pp. 538-541. See the questions put to Grote by Mill regarding Schleiermacher's views in C.W., vol. XVI, pp. 1115,1120 (letters dated 10 and 26 Nov. 1865).

${ }^{159}$ C.W., vol. XI, p. 151.

${ }^{160}$ Plato, 1:290, 2:36n.

161 J.S.Mill, "On Liberty", C.W., vol. XVIII, p. 235. 
counteract the sophists. ${ }^{162}$ Socrates' mission was the building up of a new morality in the place of the old which was incurably undermined by the sophistic schools. ${ }^{163}$ The new and true morality nineteenth-century classicists assumed Socrates sought to establish was not foreign to Christian morality. ${ }^{164}$ Socrates was for them the first conscious apologist of Christian ethics. For Grote and Mill, however, Socrates was an agnostic, whose principal aim was not to build up a new morality, but first of all to construct the science of ethics, i.e., to set up the essentially rational principles which should govern ethical questions.

The Gorgias appeared to Mill to be among the most celebrated of Plato's works: a "brilliant" dialogue. ${ }^{165}$ Mill's comments on the Gorgias are surprisingly filled with sentiment, and with a sort of pessimism. Here is Mill's vision of reality, disheartening as it is, emancipated from his father's optimistic expectation for changing, or improving, the world by means of education. ${ }^{166}$ The identity of knowledge and virtue is certainly a conclusive principle, but "All valid arguments in

${ }^{162}$ The sophists, G.F.Wiggers maintained, "were most dangerous men", and Socrates' condemnation resulted from the hatred which they bore towards him ("A Life of Socrates", in PLATO, The 'Apology' of Socrates, the 'Crito' and Part of the 'Phaedo', London 1852, pp. lxxvi-lxxvii); similarly J.W.Suvern, Two Essays on 'The Clouds' and on 'The GERAS' of Aristophanes, London 1836, pp. 6-7.

${ }^{163}$ See B.B.Rogers' preface to the translation of Aristophanes' Clouds, Oxford and London 1852 , especially p. vi.

164 J.G.Cooper earlier made Socrates' mission a totally religious one, and as motivated by Socrates' conscience of his duty to the "CREATOR and GOVERNOR of all Things" (The Life of Socrates, London 1771, p. 21).

${ }^{165}$ C.W., vol. XI, pp. 97 and 401.

${ }^{166}$ On Grote's growing pessimism towards the possibility of political and moral improvement see his wife's letter addressed to her sister (14 July 1862), Lewin Letters, vol.II, p. 246; and Tollemache, Safe Studies, pp. 137-8. 
favour of virtue, presuppose that we already desire virtue, or desire some of its ends and objects". ${ }^{167}$ The love of virtue, Mill argued, is not communicated by reasoning, but by feeling, inspiration, or sympathy.

Mill, like Grote, showed great respect and admiration for Athenian democracy ${ }^{168}$ For Mill, Grote rendered a great service to classical studies by offering an authentic account of ancient democratic Athens. "All the Greek elements of progress", Mill asserted, "in their highest culmination, were united in that illustrious city". ${ }^{169}$ An allusion to Grote is made in Mill's On Representative Government; "our great historian of Greece", he wrote, "proves in every page of his history how much the practice of the dicastery and the ecclesia raised the intellectual standard of an average Athenian". ${ }^{170}$ In the same work Mill did not omit to remark that it was due to its democratic institutions, as for instance the ballot, that Athens enjoyed eunomia and became "distinguished among the ancient commonwealths". ${ }^{111}$ Furthermore, the Greeks and especially the Athenians were the first to realize that the worth of women is not necessarily lowered because of their sex. Socrates resorted to Aspasia for instruction, and he was content in announcing that he had obtained it. ${ }^{172}$

${ }^{167}$ C.W., vol. XI, p. 150; emphasis added.

${ }^{168}$ See Pappe, "The English Utilitarians and Athenian Democracy", pp. 302, 306; Williams, "J.S.Mill on the Greeks", pp. 6, 8.

${ }^{169}$ C.W., vol. XI, p. 315.

170 "On Representative Government", C.W., vol. XIX (1977), p. 411.

${ }^{171}$ C.W., vol. XI, p. 305.

172 "The Subjection of Women", C.W., vol. XXI (1984), p. 314. Grote, like J.S.Mill, desired the enfranchisement of women. Tollemache testified that Grote believed "with Plato, that in intellect, as in other respects ... a first-class woman might be better than a second-class man" (Safe Studies, London 1895, p. 138). James Mill 
Mill is repeatedly quoted in Grote's Plato, mostly as an incontrovertible authority on issues related to Logic. ${ }^{173}$ In discussing Socrates' negative process of seeking scientific results, which had created hostility against him, Grote cited a passage from the On Liberty. This "admirable Essay", Grote maintained, "stands almost alone as an unreserved vindication of the rights of the searching individual intelligence, against the compression and repression of King Nomos". ${ }^{174}$ Mill's On Liberty, originally published in 1859 , must have exerted a considerable influence upon Grote's views. To the question 'did J.S.Mill exert any sort of intellectual influence upon Grote?' I should answer in the affirmative, with the addition that Mill, however, learned a good deal from Grote's copious works. In reality they influenced each other. So many things united them, so few divided them. ${ }^{175}$ They were both nourished in the same intellectual environment, clung to identical epistemological and ethical principles, and animated by related ideals. Mill's superiority in strict philosophical speculation had no force in the domain of the ancients, and it by no means replaced his omission to provide a sufficient account of them. Grote, in that direction, was decidedly superior.

however, regarded eligible to suffrage only males above forty. See Essay on Government, Cambridge 1937, pp. 43-5. Clarke remarks that if "Grote ever felt inclined to accept the elder Mill's view on this point, Mrs Grote would hardly have allowed him to do so" (George Grote, p. 39).

${ }^{173}$ Plato, 1:380n, 1:382n, 1:524n, 1:553-554n, 1:555n, 2:25n, 2:83n, 2:143fn, 2:249-250n, 2:271n, 2:285-86n, 2:335n, 2:375n, 2:379n, 2:545n, 3:227fn, 3:271n, $3: 383 n, 3: 487,3: 499$ n, $3: 528 n$.

${ }^{174}$ Plato, 1:266; see also 2:143n.

175 "Clearly", writes Williams, "their common utilitarian background gave them similar interests when it came to studying the past" ("J.S.Mill on the Greeks", p. 13). 
IV

\section{Conclusion}

Manuscript evidence was presented to suggest that Grote had been engaged in the study of ancient political thought much earlier than 1819 , i.e. the date he met James Mill through Ricardo. Despite his lack of a university education Grote was very educated. The elder Mill appreciated Grote's learning and clarity of thought. Bentham had no hesitation to entrust him the edition of his Natural Theology, a book published in 1822, after a year of laborious work. Grote owed much to James Mill in terms of intellectual stimulus and encouragement. His acquaintance with Mill and the utilitarian circle strengthened his adherence to empiricism and political radicalism. The prevalent idea was that Grote had been prompted by Mill to write a history of Greece. A survey of his early manuscripts suggests, however, that he had considered writing a history of Rome, a plan he probably changed at the suggestion of his friend, Norman.

James Mill felt a certain attachment to the ideals of ancient Greece. He was an admirer of Plato, and Platonic philosophy had some influence on his thought. He protested against the 'Plotinist' version of Plato by Taylor. He wrote two articles on Taylor's translation and interpretation of Plato, which now provide the clue to his understanding of the philosopher. James Mill rejected the existence of any positive aspect in Plato's philosophy. His purpose, Mill contended, was solely 'negative', i.e. to enable students to expose fallacies and give specimens of philosophic investigation. John Stuart Mill, with whom Grote kept a lifelong friendship, showed particular admiration for Plato. Though complaining about the level of Platonic studies in his day, J.S.Mill, like his father, never developed his views on the significance of Plato's thought. In a few commentary-translations of Plato's dialogues he showed that it was 
the 'Socratist Plato' who had an appeal to him. A Platonist, in J.S.Mill's view, was one who believed in the importance of dialectic in itself, and not one impatient to establish positive truths. Plato, himself, might have thought of his dogmatic conclusions as poetic fancies.

Grote did not attempt to justify Plato's doctrinal assertions on the grounds that they were made in a spirit of conjecture. He also differed from the two Mills in some aspects of his interpretation of the sophists. J.S.Mill recognized that he had nothing substantial to add to Grote's Platonic analysis. 


\section{Chapter 2}

\section{IN DEFENCE OF ATHENIAN DEMOCRACY: THE TRADITIONAL APPROACH AND GROTE'S POSITION}

\section{I}

\section{The Greek Sources}

When George Grote embarked on the task of writing the history of Greece, a long-established tradition saw Athenian democracy as the 'tyrannical rule of the mob', and a political system designed to suit the selfish temper of an imperious and ungrateful rabble. Only some Athenian orators of the fourth century were disposed towards democracy, but their voices were not convincing, nor had they, in effect, intended their writings to form a coherent defence of Athenian democratic politics. ${ }^{1}$ Their orations were related to current practical issues - such as foreign policy, or lawsuits - and their references to Athenian constitutional life were scant and incidental. ${ }^{2}$ Some of the sophists of the Periclean age are now believed to have been the first important advocates of participatory democracy. ${ }^{3}$ For many centuries,

1 A.H.M. Jones, "The Athenian Democracy and its Critics", in Athenian Democracy, Oxford 1969, pp. 41-2.

${ }^{2}$ Demosthenes, however, offered precious information on the working of Athenian democracy, from 429 to his death. See especially, On the Crown, 169-170; and Against Timocrates, particularly 19-24.

${ }^{3}$ Cynthia Farrar argues that Protagoras was "the first democratic political theorist in the history of the world" (The Origins of Democratic Thinking, Cambridge 1988, p. 77). G.B.Kerferd maintains that Protagoras' man-measure doctrine has produced "for the first time in human history a theoretical basis for participatory democracy" (The Sophistic Movement, Cambridge 1981, p. 144). See also L.Versenyi, Socratic Humanism, New Haven and London 1963, p. 37; C.H.Kahn, "The Origins of Social Contract Theory", in Kerferd (ed.), The Sophists and their Legacy, Wiesbaden 1981, pp. 92-108; J.W.Gough, The Social Contract, Oxford 1936, p. 16; P.J.Rhodes, The 
however, the brief fragments of their works which have survived, were treated with the utmost prejudice, and a systematic examination of their philosophy has been undertaken only in our century.

The prominent historians and philosophers of the fifth and fourth centuries, with the exception of Herodotus, were, as a rule, bitterly hostile to democracy. They were among the unhappy aristocrats, who "had to submit to seeing common artisans and farmers deciding public policy and judging them in the courts". ${ }^{4}$ They lived in times of extreme social scepticism, a tendency strengthened by sophistic training, and which ultimately led to a questioning of the privileges of their class. They consequently came to connect inability in politics with poverty. ${ }^{5}$ Under the Athenian system the least cultivated portion enjoyed, in their judgement, excessive advantages. The poor were considered responsible for the decline of Athens; in their view the populace gave rise to intellectual mediocrity and moral degeneration; they believed that the poor frustrated the development of a noble spirit, and subdued the rich under the pretension of advancing a national policy.

Aristophanes' sympathies, for instance, were with the landowning politicians. People with inadequate funds, in his judgement, had deceived and flattered their

Athenian Empire, Oxford 1985, p. 38; J.S.Morrison, "The Place of Protagoras in Athenian Public Life", Classical Quarterly, 35(1941):10-11; D.Loenen, Protagoras and the Greek Community, Amsterdam 1940, pp. 12-4; H.Barrett, The Sophists, California 1987, p. 39.

${ }^{4}$ W.R.Agard, What Democracy Meant to the Greeks, Madison 1960, p. 176.

${ }^{5}$ Grote persisted in attacking the "fallacy which connects political depravity or incapacity with a poor station, and political virtue or judgment with wealth" (History of Greece, London 1888, 6:513); similarly see W.S.Ferguson, Greek Imperialism, Boston 1913, p. 74; R.K.Sinclair, Democracy and Participation in Athens, Cambridge 1988 , p. 210. 
fellow-citizens with a view to securing their easy ascendancy, and becoming wealthy. The Athenian demos was in reality a despot who loved to be flattered and fooled. It was, in Aristophanes' language "a sour old man, Quick-tempered, country-minded, bean-consuming, A trifle hard of hearing". ${ }^{6}$

Thucydides does not appear to have been well-disposed towards democracy. Jones ascribes his inclination partly to a misconception of public feeling natural to his aristocratic origin, and partly to a deep-seated desire to find a moral justification for the decline of Athens. Thucydides, Jones argues, believed that Athens misbehaved against its allies and therefore its fall was deserved. ${ }^{7}$ The Athenian empire flourished in the times of Pericles' rule, because in what was nominally a democracy, power was in effect in his hands. ${ }^{8}$ The arrogant conduct of the demagogues however, who followed Pericles' death, resulted in the destruction of the consistent and harmonious foreign policy of old times. The demagogoi were persons of unvarying mediocrity, unquestionably led by self-interest, and their desires to distinguish themselves in attaining preeminence. ${ }^{9}$ The populace, seduced by their speeches, carried on a ruinous war and tenaciously rejected any peace-proposals. Cleon was an example: he abhorred the very idea of peace, since through war he enjoyed success and honours, and

${ }^{6}$ Aristophanes, Knights, 40-43. The ancient notion of the 'corruptibility of the poor' is conspicuously present throughout this comedy; see particularly 147-193, where a humble sausage-seller appears to be able, if he wished, to become "over-lord of all those people, The Agora, and the Harbours, and the Pnyx".

${ }^{7}$ Jones, "The Athenian Democracy and its Critics", pp. 71-2.

${ }^{8}$ Thucyd., II.65; Plutarch, Pericles, IX.1. Thucydides made Pericles and Cleon call the empire 'tyranny' (II.63 and III.37). Similarly Aristophanes characterized Athens' empire as tyranny (Knights, 1110-20.)

${ }^{9}$ Thucyd., II.65 and IV.21. 
because he thought that in a time of peace people would be more likely to detect his dishonest practices..$^{10}$

The Athenian democracy in the 'Old Oligarch's' treatise, despite its morally distasteful character, appears to have been a successful constitution if viewed through the criterion of its efficiency to promote the interests of the 'bad' at the expense of the 'good'. ${ }^{11}$ The Athenians, he argued, compelled their allies to voyage to Athens to have their cases tried, in order first to receive the costs of these trials, and secondly to keep their friends in the allied states protected and their enemies suffering. ${ }^{12}$ It was self-interestedness, and sheer expediency that led the Athenians to adopt this practice, and not philanthropy.

The philo-laconian Xenophon ${ }^{13}$ likewise, did not conceal his contempt for the people acting en masse. He described in the darkest terms the 'merciless' and fierce temper of the Athenian assembly. It was habitual for the mob to engage in machinations to gratify temporary passions. It was commonly believed that among the multitude "it was monstrous if the people [:to plethos, the greater number] were to be prevented from doing whatever they wished". ${ }^{14}$ Xenophon besides could not but

10 "Genomenes hesychias kataphanesteros nomizon an einai kakourgon kai apistoteros diaballon" (Thucyd., V.16).

${ }^{11}$ I.e., of the poor at the expense of the rich, or noble. [Xen.] Ath. Pol., I.4-9. The 'best', kaloi kagathoi, are opposed to the many; similarly Thucyd., VIII.48; Aristoph., Knights, 735.

12 [Xen.] Ath. Pol., I.14-6; for a defence of the judicial system, see Isocrates, Panegyricus, 113.

${ }^{13}$ Xenophon, Hellenica, II.iii.34; "kalliste men gar depou dokei politeian einai he Lakedaimonion" (the constitution of the Lacedeamonians is, we know, deemed the best of all constitutions). See, similarly, Isocrates, Areop., 60 - 61.

${ }^{14}$ Xenophon, Hellenica, I.vii.12. 
share the conviction of his master, Socrates, that it was wrong and harmful to appoint holders of public office by lot. ${ }^{15}$

Isocrates' anti-democratic sentiments found eloquent expression in the Areopagiticus. In this work he upheld the old conservative policy of the council of Areopagus, which distributed honours and punishments on the basis of the 'real' principle of equality, that is to say, in Isocrates' political thought, in proportion to qualifications and deserts. ${ }^{16}$ After the Areopagus suffered a dramatic abridgement of its censorial supervision over public manners, the city became full of "lawsuits, indictments, taxes, poverty, or wars". ${ }^{17}$ The Athenians, unable to concur with each other on the same subject for a single day, turned for advice to unprincipled politicians, charging them with all the public affairs, though no one would trust them with any of his private business. ${ }^{18}$

Plato's antipathy towards democracy was confessed without reluctance in many parts of his dialogues. In the Gorgias he did not scruple to criticize Pericles of corrupting the Athenians. He made Socrates assert that Pericles "has made the Athenians idle, cowardly, talkative, and avaricious" ${ }^{19}$ Democracy came into existence after the poor have conquered some of their opponents, slaughtered and banished

${ }^{15}$ Xenophon, Memorabilia, I.ii.9.

16 Isocrates, Areopagiticus, 21-22; the same point is made by Plato, Republic, VIII.558C.

${ }^{17}$ Areopagiticus, 50-55.

${ }^{18}$ Isocrates, On the Peace, 52.

${ }^{19}$ Plato, Gorgias, 515E.7-9. In the Laws (699e) Plato criticized the Athenians of enjoying "excessive liberty". 
others, and in the end assigned public offices by lot. $^{20}$ Democracy, in Plato's eyes, appeared the natural precursor of tyranny: tyranny was an "outgrowth of democracy". 21

Aristotle reproduced the main argument of the opponents of democracy, namely, that this form of government sought the advantage of the indigent. ${ }^{22}$ What is more, in democracies people lived as they liked, and this was, of course, a bad thing. ${ }^{23}$ The extreme form of democracy was, in Aristotle's view, nothing else but tyranny. ${ }^{24}$

\section{II}

\section{The British 'Mixed' Constitution far Preferable}

\section{to Athenian Democracy}

The eighteenth century received and adopted uncritically the judgement passed on Athenian democracy by the ancient thinkers. There was, however, a growing

${ }^{20}$ Plato, Republic, VII.557A - 558C.

${ }^{21}$ Republic, VIII.562A.7-9, 564A.6-7.

${ }^{22}$ Aristotle, Politics, III.v.4 (1279b); see also III.viii.2-3 (1284a).

${ }^{23}$ Democratia, or the government of the demos, appeared an ineffective political option to ancient philosophers because they had a pessimistic conception of human nature. Aristotle in the Politics explicitly stated that evil is inherent in every man (VI.ii.4. - 1318b.40 - 1319a.1). Thucydides observed, in the same spirit, that political enormities will continue to occur as long as "human nature remains the same" (III.82, 45). Unrestricted liberty contradicted the principal aim of political science which was, in Aristotle's language, to "produce a certain character in the citizens, namely to make them virtuous and capable of performing noble actions" (agathous politas), Nicomachean Ethics, I.ix.8 (1099b.30-33). The raison d' etre of politeia in ancient political speculation is to be found in making the best ethos.

${ }^{24}$ Politics, V.viii.18 (1312b). 
tendency to attack Athenian democracy as a means of bringing out arguments in contemporary debates. Athens was presented as the primary example of ochlocracy, of civic lawlessness, chaotic and disorderly political organization, and personal insecurity. ${ }^{25}$ As Mitchell rightly pointed out, historians were chiefly concerned to "contrast the peaceful permanence of the Spartan constitution with the ever-recurring stasis which marked the evolution and decay of the Athenian democracy". ${ }^{26}$

Early specimens of that kind of treatment were the works of Temple Stanyan, Edward W.Montagu, and the Grecian History of the poet Oliver Goldsmith. ${ }^{27}$ All of them believed that the Greek political history could provide the perennial lessons of how to secure the preservation of liberty through a balanced constitution. Their object was clear enough from the outset: to censure factional politics, to extract the political and moral lessons ingrained in Greek history, and to compare the Greek republics with the British constitution. The inevitable consequences of democratic government, Montagu argued, are civil dissentions, and in that respect the "mob government" of Athens can be termed the seat of faction. ${ }^{28}$ Solon, in Montagu's judgement, had committed a fatal mistake in entrusting the supreme power "to the giddy and

${ }^{25}$ See F.M.Turner, The Greek Heritage in Victorian Britain, London 1981, p. 189.

${ }^{26}$ J.M.Mitchell (ed.), Grote's History of Greece, condensed edn, in one vol., London 1907, p. xiii. For more on the stasis in ancient democracies, see M.I.Finley, "Athenian Demagogues", in Past and Present, (21(1962):6-7.

${ }^{27}$ Oliver Goldsmith, whose History was published in 1774, did not like Athens but he disliked Sparta too. His political narrative was poor. Cleisthenes was not even mentioned, nor any reference to constitutional changes was made. See M.L.Clarke's remarks on Goldsmith's amateurism, Greek Studies in England, 1700-1830, Cambridge 1945, p. 103.

${ }^{28}$ E.W.Montagu, Reflections on the Rise and Fall of the Antient Republicks. Adapted to the Present State of Great Britain, London 1760, p. 80. 
fluctuating populace", and to "factious Demagogues". ${ }^{29}$ Solon's laws, Stanyan believed, were enacted to suit the "capricious" temper of the Athenian mob; a mob naturally inclined to unsteadiness and extravagance..$^{30}$ Athens was led to ruin, and no human means could have preserved its integrity, for "luxury, corruption and faction", the major causes of its ruin, were far too deep-rooted. ${ }^{31}$ These historians concluded their works by presenting, what they thought as an indispensable contrast: according to Montagu, "the British constitution, as settled at the revolution, is demonstrably, far preferable to, and better formed for duration, than any of the most celebrated Republicks of antiquity". ${ }^{32}$ Stanyan justified the praise of the British constitution in the very heart of his History confessing that, "as an Enlishman", he could not resist "the temptation of saying something in preference of our own, which is certainly the nearest to perfection". ${ }^{33}$

William Mitford and John Gillies, the historiographer-royal of Scotland, were the first historians who dealt with the ancient world in a more systematic way. It is worth observing that at the time Mitford and Gillies were composing their 'Histories',

\footnotetext{
${ }^{29}$ Ibid., pp. 84-5.
}

${ }^{30}$ Temple Stanyan, The Grecian History. From the Original of GREECE, to the Death of PHILIP of MACEDON (2 vols.), London 1781 (fourth ed.), vol. I, pp. 18081. "Fickleness and inconstancy" according to Goldsmith, "were the prevailing characters of the Athenians" (Grecian History, vol. I, p. 227).

${ }^{31}$ Montagu, Reflections, p. 151.

${ }^{32}$ Montagu, Ibid., p. 375. The instructions inherited by the destiny of Athens, Montagu argued, "are highly useful for our present conduct" (p. 144).

${ }^{33}$ Stanyan, Grecian History, vol. II, 'Preface', pp. xviii-xix -my numbering). 
in Germany there was no trustworthy work on the subject. ${ }^{34}$ But their perspectives were very limited beforehand. They both wrote under the deep impression created by the events of the French Revolution, and under a condition of profound distrust of democratic government. ${ }^{35}$ Their works are imbued with a distinct feeling of the political significance of Greek history, which, they believed, could throw light upon modern events, and become an example to their contemporaries. Their historical narratives turned out to be lengthy encomiums on monarchical institutions.

Gillies, in his dedication to King George III, referred emphatically to the "dangerous turbulence of Democracy", as well as to the "incurable evils inherent in every form of Republican policy". ${ }^{36}$ The Athenian democracy, in contrast to the 'well-balanced' English constitution, provided a first-class exemplification of the devastating effects of the 'tyrannical' rule of the mob. Mitford did not judge it inappropriate to praise, in the heart of his narrative, the 'harmonious' British constitution, concluding that "We cannot consider, without wonder, that an order of things, apparently the most natural, as well as the most beneficial, never subsisted in

34 The importance of Mitford's History, as W.Wroth justly remarked, lies in "supplying a laborious English work on a comparatively neglected subject" ("Mitford, William", D.N.B., London 1894, vol. XXXVIII, p. 87). Mitford's History was translated into German in 1800. The celebrated German historian A.H.L.Heeren remarked in 1799 that among the moderns "the English have treated most successfully the subject of Grecian history". See A Manual of Ancient History, particularly with regard to the constitutions, the commerce, and the colonies, of the states of Antiquity, Oxford 1829 (first German ed. 1799), pp. 118-19.

${ }^{35}$ See J.P.Mahaffy, "A Critical Introduction", in Victor Duruy, History of Greece, London 1892, vol. I, p. 5. Mitford did not scruple to assert that "what has been passing in France may tend to illustrate Grecian history" (History of Greece, London 1808 (3rd ed.), vol. II, p. 525). Similarly, A.M.Mitchell argued that a French mob might witness in the Athenian populace their own "frivolity without [their] good breeding" (The Comedies of Aristophanes, London 1820, vol. I, p. cl).

${ }^{36}$ John Gillies, The History of Greece, London 1792, vol. I, p. iii. 
any country but our own". England, he went on, through its advantageous constitution, had always avoided the pernicious consequences of internal fermentation which destroyed Athens and Rome. ${ }^{37}$

According to these historians the 'tyrannical' form of government which flourished in Athens from the early times of Pericles, fostered a crisis in moral life, and ended in absolute social and ethical degradation. Pericles was guilty, in Gillies' view, because he advocated the privileges of the people against the rich and noble; "he embraced not only the interests, but adopted the capricious passions, of the multitude; cherishing their presumption, flattering their vanity, indulging their rapacity, gratifying their taste for pleasure without expence".$^{38}$ Mitford, in the same spirit, maintained that the rich in Athens were subjected to gross ingratitude and injustice. Every political decision depended upon the prevalent passion among the "indigent multitude"; unsteadiness and superficiality were considered the two great defects that stigmatize the "inherent tyranny of ... democracy". ${ }^{39}$ Democracy for the Athenians was simply another name for intemperance and lawlessness, and the word 'isonomia' merely implied moral irresponsibility, and the power of doing what one pleased.

\footnotetext{
${ }^{37}$ Mitford, History, vol. II, pp. 526-7; see also, vol. III, p. 102, where Mitford had felt no reservation in comparing the English judicial system with the imperfect and tyrannical Athenian.

${ }^{38}$ Gillies, History, vol. II, pp. 97-8.

${ }^{39}$ Mitford, History, vol. III, p. 477. See also, vol. I, p. 376; vol. II, pp. 449, 517, 536; vol. III, p.102. Mitchell similarly pointed to the tyranny of the Athenian mob "an imperious and ignorant rabble" (The Comedies of Aristophanes, vol. I, pp. cxxi, cxlii, and cxl). It was customary among the British translators of Aristophanes, who was regarded as an honest patriot, to write a preliminary discourse warning the reader of the evils of democratic policy. See besides Mitchell, B.B.Rogers, Aristophanes, 'The Clouds', Oxford, London and Cambridge 1852, "Preface"; and C.A.Wheelwright, The Comedies of Aristophanes, Oxford 1837, pp. ix-xii, xvi.
} 
As it may have been expected, all historians who have been mentioned above, extolled "that wonderful phenomenon in politics and in the history of humanity, the Spartan System", and contrasted it with democracy, "a form of government so intrinsically disposed to irregularity". ${ }^{40}$ It was supposed that in Sparta political influence was regularly distributed between the ephors (oligarchy or aristocracy), the Kings (monarchy), and the assembly (democracy), and such distribution was easily compared with the British 'mixed' constitution. Goldsmith, for instance, praised the Spartan laws, and argued that the division of political power "served as a check upon both, and kept the state balanced in tranquility". ${ }^{41}$ Lycurgus' policy to blend together what he found best in every kind of government, was conducive to the public good, and further it tended to inspire love of virtue and moderation. ${ }^{42}$ Stanyan believed that a Spartan under the Lycurgean constitution approached Christian morality. The balance of this admirable constitution "was held for the most part so equal, that the supreme authority did not degenerate into fierceness and tyranny, nor popular liberty start out into licentiousness and rebellion". ${ }^{43}$ Historians saw in the Spartan model, which was proved fit for long duration, an early, though unfinished, copy of the British constitution - a constitution not open to such destructive rebellions as those which had been taking place in France.

The works of Sir William Young, Sir William Drummond and Edward Lytton

${ }^{40}$ Mitford, History, vol. I, p. 198, and 282.

${ }^{41}$ Goldsmith, Grecian History, vol. I, p. 20.

42 See Charles Rollin, a French historian very popular in England, The Ancient History, London 1813 (12th ed.), vol. II, pp. 381, 387.

${ }^{43}$ Stanyan, Grecian History, vol. I, p. 95 and pp. 85-7. See also Montagu, Reflections, pp. 72-3; and Mitford, History, vol. I, pp. 200-221. 
Bulwer, which have scarcely been mentioned, were free from this strong antidemocratic bias. Yet, what is common between them and the historians examined above, was their tendency to adapt the tenor and narrative of their works to contemporary political issues. ${ }^{44}$ Young, who in 1777 published The Spirit of Athens, was an M.P. in the Whig interest. ${ }^{45}$ As he confessed from the outset his determination to present the history of Athens was formed under the conviction that its arts, science, liberty, and empire, as well as the struggles and intrigues of parties and of popular leaders, rendered the subject peculiarly British. ${ }^{46}$ What Young and Drummond share in common is that they examined Athenian history in the light of modern political philosophy, especially that of Montesquieu. ${ }^{47}$ Drummond, who was an M.P. in the Tory interest, spoke with admiration for Spartan manners and daily life, and his work constituted in fact a pamphlet of his political theory, and a vindication of the 'mixed' British constitution. The government of Sparta, Drummond argued, "excelled all the republics of Greece in the distribution of the civil power. Being a government completely mixed, it displayed the advantages of each separate portion"..$^{48}$ Drummond's Review however, as far as Athens is concerned, did not

${ }^{44}$ D.K.Sandford called Young's and Drummond's works "rubbish" which should "entirely swept away by the advanced learning and improved judgment of the present generation" ("Bulwer's Rise and Fall of Athens", Edinburgh Review, 65(1837):162-3).

${ }^{45}$ See E.I.Carlyle, "Young, William", D.N.B., London 1900, vol. LXII, pp. 399400. The Spirit of Athens was translated in German and published at Leipzig in 1777.

46 "These are matters of reflection which I have considered as deeply interesting to a British reader" (Young, The History of Athens, London 1804 (3rd ed. - the first ed. as The Spirit of Athens), pp. viii-ix); similarly W.Drummond, A Review of the Governments of Sparta and Athens, London 1794, pp. iii-iv.

${ }^{47}$ See Young, History of Athens, p. viii; and Drummond, A Review, pp. 186-8.

${ }^{48}$ Drummond, A Review, p. 61; see also pp. 56-60. 
extend beyond the Solonian constitution, and it is very likely that he considered the Cleisthenian reforms (as well as the restriction of the power of Areopagus later on by Ephialtes) detrimental to the original constitution. What distinguishes Drummond's work is that, though an admirer of Sparta, being under the influence of Montesquieu, he was generally disinclined to condemn Athenian political life, for he recognized that civil laws ought to be so adapted so as to correspond to the character of the people for whom they are made. Solon and Lycurgus devised a number of laws, and framed constitutions, which they had deemed of unique suitability to prevalent customs, minds, and the temperament of their people. ${ }^{49}$ Young's defence of Athens became moderate after the events of the French Revolution, and in a subsequent edition of his work, he thought proper to defend himself against those who called "the author of the History of Athens ... the strongest advocate for the republican system". ${ }^{50}$

Bulwer, the novelist, did not discern in Athens the gross defects of democratic government. His Athens remained incomplete because Bishop Thirlwall's History made its appearance. Bulwer frequented the utilitarian circle, and Charles Austin had been his contemporary at college. ${ }^{51}$ Bulwer admitted that the history of the Greek Republics "has been too often corruptly pressed into the service of heated political partisans", and he wished his readers to acknowledge that "whatever my own political

${ }^{49}$ See Drummond, A Review, p. 187.

${ }^{50}$ Young, History of Athens, p. xiii. Having in mind the revolution in France which "hath given birth to a tyranny of such atrocious nature", Young concluded that "the people collectively are ever the most dangerous instruments of the best intentions" (pp. xi and xiii).

${ }^{51} \mathrm{He}$ was also a member of the debating society formed by J.S.Mill in 1825. L.Stephen, "Bulwer, E.L.", D.N.B., London 1893, vol. XXXIV, pp. 382-3; and J.S.Mill, Autobiography, London and Oxford 1971, pp. 76, 119. 
code, as applied to England, I have nowhere sought knowingly to pervert the lessons of the past to fugitive interests and party purposes".${ }^{52}$ One of his most characteristic novelties was the conclusion he reached to the effect that the Ephors in Sparta were the representatives of people, and thus they should be seen in the light of the theory of representative government. Further, wavering between conservatism and reform Bulwer went on to acknowledge the historic necessity of the tyrannies in ancient Greece. ${ }^{53}$ Yet, it is worth mentioning that he anticipated Grote in defending to some extent the Athenian empire, and like Young, in recognizing the positive role of ostracism..$^{54}$ Bulwer wrote the best encomium on Athens as yet known. The life of Athens, he stated, "became extinct, but her soul transfused itself, immortal and immortalizing, through the world". ${ }^{55}$ Bulwer's interests were however mostly literary and, like Drummond, he did not expand on the reforms introduced by Cleisthenes, nor did he have great esteem for his policy. ${ }^{56}$

To sum up: the history of Greece in England before Grote had been treated as a means of advancing certain political views, and mainly those of a conservative tone. Historians like Mitford and Gillies were admittedly talented scholars, and unquestionably familiar with ancient sources, but were deficient in the task of historical criticism. Their interests were political, and they had very little to say on

${ }^{52}$ E.L.Bulwer, Athens. Its Rise And Fall, London 1837, vol. I, p. viii.

${ }^{53}$ Ibid., pp. 207-8, and 249-251.

${ }^{54}$ Ibid., vol. I, p. 407, vol. II, pp. 74-5, 337; Young, History of Athens, pp. 89n, 439. It should be noted however that Grote had already defended Athens from various accusations earlier in the Westminster Review.

${ }^{55}$ Ibid., vol. I, p. 356.

${ }^{56}$ See, Ibid., vol. I, p. 405. 
social or intellectual history. ${ }^{57}$ Democracy appeared to them capricious and tyrannical, and their admiration was reserved for the British constitution. They wrote evidently under the impact of contemporary preconceptions, and they made no effort to understand the standards of Greek morals and politics. If they wrote the history of ancient Athenian democracy it was particularly in order to condemn the idea of democracy. On the other hand, writers like Young and Bulwer, cannot be properly called historians. Their defence of Athens had been motivated by a vague reverence for the Greek spirit of liberty, but they never assumed a comprehensive attempt to conceive the limits and the implications of this spirit, as well as its genuine historical background. As J.S. Mill argued the historians of Greece who preceded Grote, have started with what it is scarcely injustice to call, no distinct conception whatever of the general state of things in Greece, the opinions, feelings, personal relations, and actions, habitual to persons individual or collective, whom they are writing about... ${ }^{58}$

\section{III}

\section{The Need of Rewriting Ancient Greek History}

There was a need for a comprehensive history of Greece as an antidote to Mitford's deliberate inconsistencies. This need was felt first among the utilitarians. ${ }^{59}$ It was during the younger Mill's education when James Mill handed Mitford's work to his son, duly warning him of his prejudices. The utilitarians aspired to join together

${ }^{57}$ Grote's History, in J.S.Mill's judgment, was "the first attempt at a philosophical history of Greece". Grote made the history of Greece "a picture of the Greek mind" ("Grote's History of Greece [I]", in Collected Works, vol. XI, pp. 275 and 276).

${ }^{58}$ Mill,"Grote's Greece - vol. VII and VIII", The Spectator, (16 March 1850) in C.W. vol. XXV, 1986, p. 1159.

${ }^{59}$ See J.S.Mill, Autobiography, p. 9. 
a refined classical humanism with the radical scientific rationalism of their era. Grote was early engaged on the task of composing a history of Greece, but his seat in the parliament did not leave him much free time. He retired from political life in 1841 "being desirous of devoting his time continuously to his great work, the History of Greece". ${ }^{60}$ In the meantime, however, Bishop Connop Thirlwall who had been a school-fellow of Grote at Charterhouse and then a Fellow and Lecturer of Trinity College Cambridge, produced the first major work in English that dealt with ancient antiquities in a comprehensive and critical way. ${ }^{61}$ Grote once claimed that had he known about Thirlwall's project he would never have begun to write the History. But the whole matter was obviously different. When Grote's two first volumes were published Thirlwall felt obliged to write to Grote that

I should have been ashamed of myself if those feelings could have been stifled or abated by my necessary consciousness of the great inferiority of my own performance ... I may well be satisfied with that measure of temporary success and usefulness which has attended it [i.e. his History], and can unfeignedly rejoice that it will, for all highest purposes, be so superseded. ${ }^{62}$

There were many differences between the two historians both in approach and argument. As far as approach is concerned Thirlwall worked under the influence of the pioneers of modern German philology and representatives of Romantic

${ }^{60}$ T.H.Lewin, The Lewin Letters, London 1909, vol. I, p. 383; H.Grote, Personal Life, London 1873, pp. 66-7.

${ }^{61}$ C.Thirlwall, History of Greece, eight vols, London 1835-43.

62 The letter is quoted by W.Smith, in "George Grote", Quarterly Review, 135(1873):122. On the completion of Grote's History Thirlwall sent another letter asking the historian to accept his "hearty congratulations on the completion of this glorious monument of learning, genius, and thought, to which ... no other literature can exhibit a parallel" (Ibid). Emphasis is added to the original. 
hermeneutics, like Wolf and Schleiermacher. ${ }^{63}$ As Bernal has argued, Thirlwall in his History incorporated the results of the new German scholarship. ${ }^{64}$ Grote was an empiricist. As Charles V. Langlois and Charles Seignobos argued, Grote's History inaugurated a new period of historical exposition, by its insistence on "the renunciation of literary ornaments and of statements without proof" ${ }^{65}$ Thirlwall was not always consistent in his arguments. Clearly, he was not disposed to examine ancient Greece in accordance to earlier attempts. But also he was not determined to cut the tie with the traditional interpretation. His arguments were moderate; but to some extent they lacked decision. In dealing with controversial subjects Thirlwall either did not express clearly his views, or he fell into contradictions. His examination of Athenian democracy was open-minded and more acute than his predecessors, but it did not go far enough as to investigate its development. Grote, on the other hand, as a faithful utilitarian, followed James Mill, who argued that a historian ought to examine, as comprehensively as possible, "the whole field of human nature, the whole field of legislation, the whole field of judicature, the whole field of administration,

${ }^{63}$ See J.P.Mahaffy "A Critical Introduction", in V.Duruy, History of Greece, London 1892, vol. I, p. 7; and for the movement of Romantic hermeneutics, James M.Powell, "Introduction", in G.G.Iggers and J.M.Powell (ed) Leopold von Ranke and the Shaping of the Historical Discipline, New York 1990, pp. 8-9.

${ }^{64}$ Martin Bernal, Black Athena. The Afroasiatic Roots of Classical Civilization, London 1987, vol. I, p. 323.

${ }^{65}$ Langlois and Seignobos, Introduction to the Study of History, London 1898, p. 310. Arnaldo Momigliano called attention to Grote's "vast learning, and respect for the evidence" (George Grote and the Study of Greek History, London 1952, p. 11). A.D.Lindsay argued that Grote's work "was the first great history of Greece written in the spirit of scientific criticism which marked the renascence of classical studies in the nineteenth century" (Introduction to Grote's History, London 1906 (Everyman's ed.), vol. I, p. vii). 
down to war, commerce, and diplomacy". ${ }^{66}$ Matured in the spirit of utilitarian empiricism he adhered to the laws of historical evidence, renunciating false impressions and mere conjectures. ${ }^{67}$ Thirlwall's "great and solid book was ousted at once by the appearance of Grote's history". 68

Turner, however, maintains that Grote's work does not differ in its original purpose from that of his predecessors. Grote's History is important not as a contribution towards an impartial examination of Greek history, but for the opportunity it affords us, to enter into Victorian political life, and be informed at first hand of party-rivalries. For Turner, therefore, the study of Greek history in Victorian Britain "would always mean political history that was as profoundly involved with the present as with the past". 99 Turner places Grote's work in the heart of contemporary political debates, and argues that Grote's History, as well as Mitford's, should be viewed

66 James Mill, History of British India, London 1817, vol. I, p. xix. Grote, however, did not apply the theory of Utility to judge historical events, as Mill had done. He also did not follow Mill in examining history for contemporary use. (See W.Thomas, The Philosophic Radicals, Oxford 1979, p. 98.) Mill abstained from analysing characters and examining motives and emotions; Grote quite the contrary.

${ }^{67}$ A history of India, argued James Mill, to be good for any thing, must be "A Critical History"; "the man best qualified for dealing with evidence, is the man best qualified for writing the history of India" (British India, vol. I, pp. x, and xiv, emphasis added). See also James Mill's Outline of the Courses of Lectures, designed for the University of London, in Grote's collection, Univ. of London Library, B.P.68(4), pp. 9-10. The historian of British India called attention to the "rules for weighing [historical evidence], and ascertaining its force". In his history of Greece, Grote, in L.Stephen's view, "resembled an ideal judge investigating evidence in a trial" (The English Utilitarians, London 1900, vol. III, p. 338).

${ }^{68}$ Mahaffy, "A Critical Introduction", in V.Duruy, History of Greece, vol. I, p. 8. See also Bernal, Black Athena, vol. I, p. 327. We are informed by W.Mure that Grote's History was that early as in 1851 , i.e. before its actual completion, "used as a text-book in some of our public academies". See Remarks on two appendices to the second volume, third edition, of Mr.Grote's History of Greece, London 1851, p. 15.

${ }^{69}$ Turner, Greek Heritage in Victorian Britain, p. 194. 
mainly "as vehicles for contemporary political polemics". Both historians, in his judgement "distorted evidence to that end"..$^{70}$ Turner is predisposed to associate every original argument in Grote's work with the narrow objectives of party orientation, ${ }^{71}$ and, consequently, fails to appreciate the actual revolution which Grote occasioned in the field of ancient historical research. Grote is thus reduced to a talented political, or party, propagandist. Turner in effect endorses the judgement of Grote's contemporary critics, and especially John Anster's and John Stuart Blackie's, who had maintained that the great defect of the History is the polemical vein which runs through it, and which is derivative of Grote's original purpose in writing this work, namely, to correct the misrepresentations of Mitford. Hence, according to Anster, whereas Mitford appeared as the passionate admirer of monarchy and Sparta, Grote, on the other hand, presented himself as the advocate of democratic institutions and Athens. Thus, Anster concluded, with "many points of difference between the two historians, there are ... more points of resemblance than Mr.Grote would, perhaps, be willing to admit". Both bear the impress of their parties; Mitford reminds us of the period of the French Revolution that "had driven Toryism mad", and Grote of the Whigs and the debates over the Reform Bill and the Ballot. ${ }^{72}$

${ }^{70}$ Ibid., p. 214. See in addition p. 200, where Turner compares Mitford's rehabilitation of tyranny with Grote's favourable portrait of the demagogues.

${ }^{71}$ Similarly W.L.Davidson, Political Thought in England, London 1915, pp. 236. Fairer in his judgment is M.L.Clarke who believes that "Grote's History may justly be considered the most distinguished example of Benthamite historiography" (George Grote, London 1962, p. 106, emphasis added).

72 John Anster, "Grote's Greece", Dublin University Magazine, 45(1855):480. Similarly J.S.Blackie argued persistently that Grote systematically assumed a "violent polemical attitude" ("Plato", Edinburgh Essays for 1856, Edinburgh 1857, p. 7n.2); see also Four Phases of Morals. Socrates, Aristotle, Christianity, Utilitarianism, Edinburgh 1871, p. 33: "Mr. Grote is characteristically a polemical historian". 
Such statements are misleading. Had Grote's work served the narrow political expediencies of Turner's assumption it would be of little use to us today. ${ }^{73}$ But Grote's History was the first complete defence of Athenian democracy based on evidence and critical judgement that was ever produced. Grote gave new life, or, perhaps, a life that never existed before, to the subject, enriched historical research, and caused a revolution in Greek historical studies.

\section{IV}

\section{Grote's Early Pieces}

Early in 1826, in an instructive article in the Westminster Review, Grote gave signs of his intention to write a history of Greece in a way which differed from the traditional works. He pretended to review Clinton's Fasti Hellenici ${ }^{74}$, but his article turned into a direct attack on Mitford. Even prior to 1826, and most likely even earlier than 1822, Grote made long extracts from and extensive notes on Mitford, which suggests the importance he gave to the task of disproving that historian's allegations. ${ }^{75}$ That he singled out Mitford's work for criticism is not surprising. ${ }^{76}$

${ }^{73}$ F.E.Sparshott believes that Grote's History is of no value to us today. See "Introduction" in J.S.Mill, C.W., vol. XI, p. xxx. Scholars like de Ste Croix, Finley, Kerferd, Guthrie, Popper, to mention only few, would not agree with him.

${ }^{74}$ H.F.Clinton, Fasti Hellenici. The Civil and Literary Chronology of Greece from the Earliest Accounts to the Death of Augustus, in three vols, Oxford 1824.

${ }^{75}$ See BL Add. MS 29,520, fos. 171-200, 201-211. This is an unpublished essay "On the Athenian law-proceedings", written, perhaps, earlier than 1826, and constituted an attack on Mitford.

${ }^{76}$ Grote, himself, surely made his first acquaintance with Greek antiquity from Mitford, and his influence on him when youth might have been of some importance. Early manuscript notes show that Grote was somewhat critical of Athenian democracy; but his strictures were addressed to 4th century Athens. See BL Add. MS 29,520 
Mitford was the most influential historian of the period, and his strong moral and political opinions led him to paint in forbidding colours Athenian democracy and its institutions. ${ }^{77}$

The greatest defect that Grote attributed to Mitford was his failure to explain the nature of Greek society and the operation of its institutions. Grote believed that democratic institutions gave an unparalleled stimulus to the development of individual talent. $^{78}$ Mitford, in Grote's judgement, had also ignored the political implications of the smallness of the Greek city-states. The size of the Greek polis was one of the fundamental reasons for the rise of civilization through art, rhetoric, and philosophy. Mitford often censured the acts of the people en masse ${ }^{79}$ but how could it be otherwise? The smallness of the city entailed a prevalence of community feeling, and ambitious men were involved in a competition for the means by which political power was acquired. Their instrument was undoubtedly that of persuasion in large assemblies. Thus flourished the art of rhetoric, and sophistic education. The art of persuasion, according to Grote,

of which oratory is one branch, can never be much cultivated except in a free society. It is only where men are free that their actions can be much influenced by persuasion. Liberty and the art of persuasion seem

(1815-1851), especially fos. 25-6, 34-5, 92-3. Still, he would add that "the Athenian constitution was with all its defects the best existing in Greece" (fo. 51).

${ }^{77}$ Grote guessed that "should Grecian history ever be re-written with care and fidelity, we venture to predict that Mr.Mitford's reputation ... will be prodigiously lowered". And he added: "That it should have remained so long exalted, is a striking proof how much more apparent than real is the attention paid to Greek literature in this country" ("Fasti Hellenici. The Civil and Literary Chronology of Greece, from the 55th to the 124th Olympiad", Westminster Review, 5(1826):330-31).

${ }^{78}$ Grote, Ibid., p. 270.

${ }^{79}$ Ibid., p. 275. 
to be so necessarily connected that we might almost determine where one was not, there neither the other exists. ${ }^{80}$

An aspiring politician, should have been "master of those circumstances which govern the train of human ideas and affections; he must be initiated in short, in the philosophy of human mind". ${ }^{81}$ Grote argued that it was amidst these political and historical circumstances, which Mitford and others unreservedly censured, that the philosophy of mind as a science had its beginning: the most valuable service which Greek people had rendered to posterity. Among the Greek states, those which brought into operation the incentives to individual excellence were the democratic (a "sort of open aristocracy"82) and not the closed oligarchies.

Grote then proceeded, like James Mill earlier, to define the qualities desirable in an historian - which, in his judgement, Mitford lacked. The first was the ability to trace out and report the facts of the period with which he dealt. The second was his ability to analyse these facts, and give them a form in terms of causes and effects. ${ }^{83}$ Mitford failed entirely in both aspects of the historian's proper activity. Consequently, any philosophical exposition of the tendency of Athenian institutions was wanting. ${ }^{84}$ The few remarks on Greek philosophy and society made by Mitford were pervaded, Grote believed, by his strong moral and political biases. Mitford's real objective was

${ }^{80}$ University of London Library MSS 429/3 (1817), fo. 142.

81 "Fasti Hellenici", p. 276.

${ }^{82}$ Ibid., p. 280.

${ }^{83}$ Ibid., p. 280. Cf. James Mill, British India, vol. I, pp. x-xi.

${ }^{84}$ Grote conceived history as an all-inclusive study of human thought: "An author who leaves the intellectual philosophy of the Greeks unexplored, cannot assuredly convey even the faintest idea of the rank which they occupy in the scale of human improvement" ("Fasti Hellenici", p. 281). 
not genuinely historical: it was rather to praise oligarchy and deprecate democracy. It is not accidental, of course, that Philip of Macedonia was presented in his History as a model of princely clemency and disinterested virtue. ${ }^{85}$ Far from constituting an historical analysis of Greek life his statements were an exposition of his peculiar prejudices.

Grote's second appearance in historical debate about Greece took place in 1843 , only three years before his first volume was published. It constitutes a second introductory essay to his History. His article was intended to be a review of Niebuhr's Griechische Heroen Geschichten (1842), a remarkable contribution to the exploration of Greek mythos. ${ }^{86}$ English historians and many others had attempted to elicit history from fable, and overestimated the possibility of extracting truth from fiction. ${ }^{87}$

${ }^{85} \mathrm{He}$ called him "the popular King of a free people" (History, vol. IV, p. 621, and pp. 530-1). Grote in an early essay, ("Philip of Macedon", dated 15 Nov. 1815), showed his disagreement with Mitford regarding this prince; see BL Add. MS 29,520, fo. 17. In the same spirit Mitford described the Persians as "a people of liberal sentiments and polished manners, beyond almost any other in all antiquity" (Ibid., vol. I, p. 411, and further vol. III, p. 226). Cf. Grote, History, 7:181n.2.

${ }^{86}$ See Grote's remarks on Niebuhr's interpretation of myths, in BL Add. MS 29,514 (1818-1831), fo. 311. On the debate about mythology see also K.O.Muller's, Prolegomena zu einer wissenschaftlichen Mythologie, Gottingen 1825, and G.C.Lewis' review of that book in "Mythology and Religion of Ancient Greece", Foreign Quarterly Review, 7(1831):33-52.

${ }^{87}$ Hume, of course, argued that the "fables which are commonly employed to supply the place of true history ought entirely to be disregarded" (History of England, London 1825, vol. I, ch. 1, p. 13). Jacob Bryant had systematically exhibited the incredibility of ancient myths, and it is not accidental that James Mill pronounced his work of "singular merit" (British India, vol. I, p. 102n). Bryant argued that his purpose "has been throughout to give a new turn to ancient history; and to place it upon a surer foundation" (A New System, or, an Analysis of Ancient Mythology: wherein an Attempt is made to divert TRADITION of FABLE; and to reduce the TRUTH to its Original Purity, London 1774, vol. I, p. xvii). Bryant's work might have been of some use to Grote; see BL Add. MS 29,517 (1826-1832), fo. 92. Goldsmith was also paradoxically disinclined to incorporate myths into history; see Grecian History, vol. I, p. 3. 
Gillies, for instance, spoke without reservation about the "successful adventures of the Argonauts, the glorious, though destructive, expedition against Troy"; 88 and Mitford referred credulously to the "early age of Agamemnon". ${ }^{89}$ According to Grote, legend, in Niebuhr's exposition, was not "squeezed and tortured into authentic history".9 Niebuhr insisted that a portion of the mythological past is simply "miraculous and impossible, and bears the character of a mere popular tradition".91 Grote's aversion to mere conjecture led him to draw the distinction between legend and factual history. The mythical subject, in Grote's view, emerged as plausible fiction which corresponded to what he called, the "mythopoeic propensity"92 of the age. Mythos for Grote was neither degenerated fact, nor misreported reality. It was legitimate and genuine fiction, believed to be history, but which derived directly from the prevalent emotions of the public. These legends, as he argued in the History, were significant as valuable memorials of the state of societies, the people's feelings, as well as their intelligence..$^{93}$ The mythical past could be recorded as history if it was deducible "by some reasonable chain of collated evidence". ${ }^{94}$ Grote argued, however, and this was

${ }^{88}$ Gillies, History of Ancient Greece, vol. I, p. 153.

${ }^{89}$ Mitford, History, vol. IV, p. 621. See also Heeren, Manual of Ancient History, p. 137.

${ }^{90}$ G.Grote, "Grecian Legends and Early History", Minor Works, p. 77. This article was originally published in the Westminster Review, 1843, and reprinted in Minor Works, from which references are made.

${ }^{91}$ B.G.Niebuhr, Lectures on Ancient History (delivered in 1829-30), London 1852, p. 339; see also Lectures on the History of Rome, London 1848, particularly pp. 2, 3, $7,22$.

92 "Grecian Legends", p. 88.

${ }^{93}$ History, 2:2.

94 "Grecian Legends", pp. 87, 122. 
of great significance as far as his defence of Athenian democracy was concerned, that this past should not be ignored by the historian, since it assisted him to understand the subject-matter and the intensity of feelings prevalent in Greek religion. Because to treat Greek history without Greek religion "is to render it essentially acephalous". 95 For Grote, in studying Greek politics of ancient times, contemporary religious sentiment should be given its due place. An attack on the gods of the city, was interpreted by the ancients as an attack on its constitution. ${ }^{96}$

These legends and religious antiquities corresponded to "a pseudo-historical past suited to the non-historical mind". 97 From the first Olympiad onwards (776 B.C.) a new era started; actual facts were no longer intermingled with feelings fervent and unanimous. ${ }^{98}$ The mythopoeic propensity gave way to rational curiosity. The mythical narrative degenerated and lessened its emotional intensity in the hands of prose mythographers, who had gradually replaced the poets. After 776 the Greek governments experienced considerable improvement, and the Greek mind made an important advance "socially, ethically, and intellectually".99 Many of the ancient myths became utterly disharmonious with the altered tone of public thought. The idea

${ }^{95}$ Ibid., p. 89; see also p. 129.

96 The laws of the city were attached to the divine; see Soph. O.T., 865: nomoi upsipodes, ouranian di' aithera teknothentes; also Antigone, 278: when Polynices made war against the city he was further assumed to be attacking the 'national' gods as well.

97 "Grecian Legends", p. 92.

${ }^{98}$ BL Add. MS 29,521, fo. 6. Bryant argued earlier that "I can afford credence to very few events, which were antecedent to the Olympiads" (Analysis of Ancient Mythology, vol. I, p. xi).

${ }^{99}$ History, 1:403. 
of an external inspired authority was passing away from the superior minds. Finally, there gradually developed an "historical sense", and a habit of recording and combining positive facts. ${ }^{100}$ The sophists and the philosophers, being constructively sceptical, tried to distinguish between the literal and the symbolic meanings of myths.

Grote's article on the "Grecian Legends" remains an important specimen of his positive and systematic approach to the Greek past. Taken together with the article on Mitford, they are suggestive of the major tendencies of his thought, namely, his empirical approach to historical issues and his approval of democratic institutions. Grote did not attempt to obscure his attachment to the idea of ancient democracy, though he cautiously added that "We are far from wishing to dissemble, or to lessen their defects". ${ }^{101}$ But let us examine closely how these tendencies shaped the structure and argument of his greatest work, the History of Greece.

100 "Grecian Legends", p. 101; History, 1:385.

101 "Fasti Hellenici", p. 293. 


\section{Chapter 3}

\section{ATHENIAN DEMOCRACY RECONSIDERED}

The arguments Grote used in defence of Athenian democracy can be classified into two categories. The first comprises those designed to vindicate Athenian political institutions and practical policy. In this category should be placed his observations on the policy of Areopagus, the defence of ostracism, the argument concerning the distinction between the Athenian hegemony and the Athenian empire, his account of the demagogic function as well as his portrayal of the Athenian character, and finally his unsympathetic presentation of Sparta. The second category consists of those arguments which are attached to a more philosophical analysis, such as his defence of the sophists, and his criticisms of the political aspect of Plato's philosophy. The second category may be ascribed to a later stage of his life, when he committed himself to the philosophical examination of the Platonic corpus. ${ }^{1}$

I

\section{Solonian Constitution - Not Democratic}

The real Athenian democracy, in Grote's judgement, began properly with Cleisthenes, and not with Solon, as was commonly believed. ${ }^{2}$ Grote wanted probably to correct the view that the government of Athens "after the abolition of Monarchy,

\footnotetext{
${ }^{1}$ The second category will be examined in chapters six and seven. Grote's defence of the sophists first took place in the History (ch. 67th). In the Plato Grote reverted to some of his old arguments, though he emphasized more their contribution to the awakening of the philosophic spirit.

${ }^{2}$ History, 2:494-499, 3:359. Cf., however, A.H.L.Heeren, Manual of Ancient History, Oxford 1829, p. 139; and E.L.Bulwer who called the Solonian constitution, "an aristocracy of property" (Athens, Its Rise and Fall, London 1837, vol. II, p. 330).
} 
was truly democratick"; ${ }^{3}$ and to answer those, like Drummond, who criticized Solon's reforms as imposing "too slight a curb on the liberty of the people". ${ }^{4}$ The constitutional changes, enforced by Cleisthenes, greatly lamented in Mitford, ${ }^{5}$ found Grote's hearty approbation. The Solonian constitution was nevertheless the indispensable foundation of the forthcoming democracy. Solon's laws, Grote believed, helped the correction of legal and political irregularities, but they afforded only a limited expression to the popular will. The Athenian government in the times of Solon was a moderate oligarchy. ${ }^{6}$ Grote praised particularly the Solonian law which pronounced a citizen who remained inactive and neutral in a sedition to be dishonoured and disfranchised. ${ }^{7}$ This law helped to strengthen the principle of political participation, and highlighted the importance of some positive sentiment on the part of the citizens. When the people conceived themselves sovereign under democratic institutions, this Solonian law naturally came to an end.

After the expulsion of the Peisistratids, ${ }^{8}$ Cleisthenes proceeded with prudence

${ }^{3}$ E.W.Montagu, Reflections on the Rise and Fall of the Antient Republicks, London 1760, p. 74.

${ }^{4}$ W.Drummond, A Review of the Governments of Sparta and Athens, London 1794, p. 107.

${ }^{5}$ W.Mitford, History of Greece, London 1808, vol. I, p. 304, called Cleisthenes a tyrant, who had equal power with Peisistratus, but unequal moderation.

${ }^{6}$ History, 2:495. J.Gillies abstained from censuring Solon, for in his constitution, "men of property and ability were alone entrusted with the administration of government". That constitution maintained "a due distinction of ranks in society" (History of Ancient Greece, London 1792, vol. II, p. 114).

${ }^{7}$ History, 2:509-511. See Aristotle, Ath.Pol., VIII.5.

${ }^{8}$ W.Young approved of Peisistratus' policy (History of Athens, London 1804, p. 60). See also Montagu, Reflections, pp. 83-4; Bulwer, Athens, vol. I, pp. 249-251. Mitford, as it would be expected, wrote Peisistratus's encomium; see History, vol. I, 
and skill to revolutionary measures, which ultimately reinforced the democratic system. Though he preserved all the main features of the Solonian constitution, at the same time he made a number of remarkable modifications. ${ }^{9}$ The Senate of Five Hundred became now an indispensable body throughout the whole Athenian political system. He also established the selection of the senators by $\operatorname{lot}^{10}{ }^{10}$ Thus the people received from the Cleisthenean constitution the real attributes of sovereignty, being also called into direct action as "dikasts" or jurors. The reform of Cleisthenes was, however, not perfectly democratic, ${ }^{11}$ for it still excluded the fourth class of the Solonian division from all individual office, the archonship among the rest. ${ }^{12}$ But whereas in Solon's constitution only the members of the first class (Pentakosiomedimnoi) were eligible to the archonship, Cleisthenes extended the eligibility to the first three classes.

\section{II}

\section{The Senate of Areopagus}

The Cleisthenean reform, according to Grote, did not render the constitution

p. 298 , and pp. $549-550$.

${ }^{9}$ History, 3:354-5.

${ }^{10}$ History, 2:499, 3:354-5. On this law, see C.Hignett's comments, A History of the Athenian Constitution to the end of the Fifth Century B.C., Oxford 1970, p. 231.

${ }^{11}$ As Hignett argues, Cleisthenes' "moderate democracy was far removed from the radical democracy of Pericles" (History of the Athenian Constitution, p. 217).

${ }^{12}$ History, 3:366-7. 
perfectly democratic for it preserved the functions of Areopagus. ${ }^{13}$ The Areopagites constituted, in the times of Solon, the principal body in the state. Mitford believed that Solon hoped by restoring the Areopagus to provide a "powerful weight in the balance against the uncertainty and turbulence of democratical rule". ${ }^{14}$ Grote argued that afterwards, during the reign of the Peisistratids, the Areopagites had become willingly obedient to the new rulers, and some new members, of Peisistratus' choice, were appointed. As a result, the Areopagites must have received with hostility the novelties of Cleisthenes, viewing their position to have lost its pre-eminence. Yet, it was only at the period of Pericles' government that their functions were drastically curtailed. ${ }^{15}$ During the Cleisthenean constitutional period their formal power was still considerable; and worst of all, in Grote's judgement, the Areopagus was a potential threat to democratic institutions, since it became the focus of the party of oligarchical resistance. "We thus see", Grote argued, "how it happened that the past archons, when united in the senate of Areopagus, infused into that body the sympathies, prejudices,

${ }^{13}$ Aristotle remarked that the Areopagus was the oligarchic element of Solon's constitution (Politics, II.ix.2 - 1273b.40). This institution argued J.B.Bury, "was incompatible with the development of democracy, and it was inevitable that it should be ended or mended" (History of Greece, London 1904, p. 347). See also A.W.Gomme's remarks, in "The Working of the Athenian Democracy", More Essays in Greek History and Literature, Oxford 1962, p. 181.

${ }^{14}$ History, vol. I, p. 282.

${ }^{15}$ The Areopagus, argued W.R.Churton, "was at length deposed, and licentiousness was no longer rebuked or discountenanced: for Pericles ruled by corruption, while he maintained his own integrity unimpeachable" ("Athens in the time of Pericles, and Rome in the time of Augustus", The Oxford English Prize Essays (prize for 1824), Oxford 1830, vol. IV, p. 86). Thomas Mitchell, in like spirit, argued in favour of Areopagus; see "Greek Courts of Justice", Quarterly Review, 33(1826):340. 
and interests of the richer classes". ${ }^{16}$ Thus Grote implied that democracy was constantly endangered when sinister and particular interests prevailed. ${ }^{17}$ As long as a group of people, or a faction with specific and selfish interests, acted contra community interests, Grote believed that democracy was not feasible. ${ }^{18}$

The Athenian constitution thus became democratic in the times of Ephialtes and Pericles, when the conflict between this particular section of privileged citizens and the rest had intensified, and Areopagus caused its own self-destruction. But Grote would not admit that the rich, after the curtailment of the function and role of the Areopagus, were disgraced or ceased to perform their duties. Mitford, on the contrary, had argued that the "higher ranks", "in a government where the multitude was despotic", were severely oppressed. ${ }^{19}$ Democracy, as Grote acknowledged, meant heavier expenses and larger taxes, but it afforded them the opportunity to form political (oligarchical) clubs, the hetairies. Mitford had maintained that these clubs were organized by the noble and wealthy as a protection against "the oppression of

${ }^{16}$ History, 3:368. Turner interprets Grote's argument as closely related to the political conditions of Victorian age. See Greek Heritage in Victorian Britain, pp. 219, 231.

${ }^{17}$ Grote's argument echoes plainly the utilitarian point of view. See, J.Bentham, Constitutional Code (ed. F.Rosen and J.H.Burns), Oxford 1983, vol. I, pp. 105-6, 433; An Introduction to the Principles of Morals and Legislation (ed. J.H.Burns and H.L.A.Hart), London 1970, pp. 14-5n; A Fragment on Government (ed. J.H.Burns and H.L.A.Hart), Cambridge 1988, pp. 199-202. James Mill, similarly, joined issue against sinister interests in his Essay on Government, (ed. E.Barker), Cambridge 1937, pp. 25, 34,45 .

18 A.R.Burn points out that the Areopagus, in effect, could form the executive power in the state. See Pericles and Athens, London 1948, p. 29. See also Hignett, History of the Athenian Constitution, pp. 195 and 199.

${ }^{19}$ W.Mitford, History, vol. II, p. 114; similarly C.Thirlwall, History of Greece, London 1837, vol. IV, p. 218. See also the remarks of Augustus Boeckh, The Public Economy of the Athenians, London 1857, pp. 785. 
democratical despotism". ${ }^{20}$ The hetairies, Grote believed, took the form of organized clubs, with certain programs of action, and worked against the democratic rule. Furthermore, in a preparatory essay to his History of Greece, entitled "Liturgies of the Athenians", Grote argued that in fact the liturgies and choregies were "sources of advantage and power to the rich as a body".

To serve trierarchies and choregies, was to purchase advancement to office for himself, and for those whom he chose to befriend; it was to secure pardon before the tribunals for any slight offence, and mitigation of punishment for a great one. ${ }^{21}$

According to Grote, these oligarchical clubs conspired with Alcibiades to originate the Oligarchy of Four Hundred, which brought Athens next to absolute ruin. ${ }^{22}$ When the aristocrats acted solely on the base of their own interests, they caused the fall of democracy.

${ }^{20}$ Mitford, History, vol. II, p. 434.

${ }^{21}$ See, BL Add. MS 29,520, fos. 57 and 74. (It is interesting to note that Plato himself, as Laertius informed us, "acted as a choregus ... the cost being defrayed by Dion", III.3.) These expenses, Grote argued elsewhere procured also "on the part of the Athenian judges, a standing bias in favour of wealth and family", "On the Athenian law-proceedings" (Ibid., fo. 90). Further, Grote in his manuscript notes was sceptical as to whether or not the poor in Athens were treated unfavourably by the courts of justice; see BL Add. MS 29,516 (1828 \& 1840-50), fos. 30, 35, where Grote noted Crito's pressure upon Socrates to escape. Otherwise, he would have been blamed by every one for not procuring his friend's release, which is "evidence that the rich could evade the law whenever they pleased" (fo. 35); similarly, Bulwer, Athens, vol. II, pp. 392-3.

${ }^{22}$ History, 6:238-9. On the hetairies, see W.R.Agard, What Democracy Meant to the Greeks, Madison 1960, p. 180. 


\section{In Defence of Ostracism}

The law of ostracism is closely related to the Cleisthenean constitution. ${ }^{23}$ Many historians in the eighteenth century seemed to have copied Plutarch, who in the Life of Themistocles, defined ostracism as a means of curtailing the dignity and preeminence of all whom the Athenians thought were not complying with their democratic temper. Ostracism, according to Plutarch, was an unjust measure originated by that "jealousy which delights to humble the eminent" ${ }^{24}$ Historians from antiquity until the age of Grote, condemned in ostracism the evils of the 'tyranny of the mob' ${ }^{25}$ an excited populace could, at any time, put into exile the most eminent men of Athens. Thus Mitford's interpretation rendered ostracism "a peculiar mode of repressing the dangerous superiority which great abilities and superior character might acquire in a republic". ${ }^{26}$ The law of ostracism, in Stanyan's judgement, became the real "Test of a man's merit". ${ }^{27}$ Ostracism, in effect, was the standard example anti-

${ }^{23}$ Plutarch (Arist. VII.2) ascribed to Cleisthenes the institution of ostracism. On whether ostracism was Cleisthenes' innovation, see Rudi Thomsen, The Origins of Ostracism, Copenhagen 1972, especially ch. III, "Was the Ostracism Law Kleisthenic?" (pp. 109-142); David Stockton, The Classical Athenian Democracy, Oxford 1990, p. 34.

${ }^{24}$ Plutarch, Themistocles, XXII; also Nicias, XI.1; Aristides, XII.

${ }^{25}$ With the exception of Young, History of Athens, p. 89n; and Bulwer, Athens, vol. I, p. 407; also vol. II, p. 74. B.G.Niebuhr similarly believed that ostracism was a "beneficial regulation" (Lectures on Ancient History, London 1852, p. 333).

${ }^{26}$ Mitford, History, vol. I, p. 423; see also vol. II, p. 392.

${ }^{27}$ Stanyan, Grecian History, London 1781, vol. I, p. 298: he also argued that ostracism was "a barbarous discouragement to all sorts of merit and ambition" (p. 203). D.K.Sandford ascribed the law of ostracism to "the blind and envious folly of the multitude" ("Bulwer's Rise and Fall of Athens", Edinburgh Review, 65(1837):167). 
democratic writers referred to in favour of their own positions. As Grote stated, he should hardly have said so much about the institution of ostracism

if the erroneous accusations, against the Athenian democracy, of envy, injustice, and ill-treatment of their superior men, had not been greatly founded upon it, and if such criticisms had not passed from ancient times to modern with little examination. ${ }^{28}$

Grote's attitude regarding ostracism transformed radically the whole field of discussion. It is hardly too much to say, he argued, "that without this protective process none of the other institutions would have reached maturity" ${ }^{29}$ Grote believed that ostracism was engendered by the necessity of creating in the multitude "that rare and difficult sentiment which we may term a constitutional morality". ${ }^{30}$ The latter term meant for Grote a paramount reverence for the forms of the constitution, which urged obedience to those acting under and within these forms. Obedience to constitutional arrangements, and constitutional morality in general, would have been utterly unattainable had it not been attached to a perfect confidence, that despite party contest, these arrangements will be solemnly preserved. Ostracism was a fundamental democratic lesson concerning the formation of self-imposed limits to ambition. ${ }^{31}$ The Athenians of Cleisthenes' period could have hardly attained a clear recognition of these limits. In the infancy of Athenian democracy ostracism provided the means of reducing the possibility of transgressing them, and thus jeopardize the free working

\footnotetext{
${ }^{28}$ History, 3:378.

${ }^{29}$ History, 3:369.

${ }^{30}$ History, 3:372, emphasis added.

${ }^{31}$ History, 3:372: The ostracism tended to safeguard the "co-existence of freedom and self-imposed restraint - of obedience to authority with unmeasured censure of the persons exercising it".
} 
of the constitution. An over-ambitious politician, or a formidable group of conspirators, would have had to face the united majority of citizens, and his, or their plans were most probably frustrated. Grote pointed out the close analogy of ostracism to the exclusion of a known pretender to the throne in a monarchy, as for instance, the duke of Bordeaux, Napoleon after 1815, or Charles Edward in England during the eighteenth century. ${ }^{32}$

In the course of Athenian history ostracism, as Grote argued, proved a prudential and powerful weapon in the hands of democracy; it ceased to operate when democracy, and democratic feeling, became utterly assured..$^{33}$ In the case of the rivalry between Themistocles and Aristeides, which preceded the banishments of Kimon and Thucydides, a vote of ostracism was invoked. The rivalry between the two chiefs became so bitter and menacing that it threatened the peace of the city. The peace, Grote argued, was preserved mainly by ostracism..$^{34}$ The banishment of Kimon again, which Plutarch so vehemently criticized, sustained democracy and helped to secure the avoidance of unnecessary bloodshed..$^{35}$ It was during Pericles' and Ephialtes' co-operation for abridging the excessive authority of the senate of Areopagus, that Kimon and his oligarchical party gained their ascendancy. Kimon, of

\footnotetext{
${ }^{32}$ History, 3:378.
}

${ }^{33}$ History, 5:505. See Young's remarks on the abolition of ostracism, History of Athens, p. 439.

${ }^{34}$ History, 4:149. V.Ehrenberg argues that in the case of Themistocles it is "hardly sufficient to speak of the ingratitude of Athenian democracy. More likely, Themistocles fell a victim to his own difficult character" (From Solon to Socrates, London 1973, p. 199).

${ }^{35}$ Mitford detected in the fate of Kimon the marks of "a defective constitution, and law and justice ill assured" (History, vol. I, p. 550). See also, Stanyan's remarks on the occasion, Grecian History, vol. I, p. 298. 
course, was not banished merely due to the ascendancy of his party. He was banished when he had already lost the confidence of the Athenians, i.e. after the humiliating dismissal of the Athenian troops from Laconia, where they went, at his urging, to aid the Spartans in reducing the revolted Helots. ${ }^{36}$ It was very likely that Kimon seeing his power diminishing, would take any measure to regain his ascendancy, even at the ultimate cost of democracy itself. Amidst the bitterness of political contest, which consequently arose, his opponents proposed a vote of ostracism. The vote ended in the expulsion of Kimon. ${ }^{37}$ On this occasion, Grote argued, "we see the ostracism invoked to meet a period of intense political conflict, the violence of which it would at least abate, by removing for the time one of the contending leaders". ${ }^{38}$

In another case, equally significant in the course of Athenian history, Thucydides - son of Melesias - was condemned to ostracism. After the death of Kimon, the oligarchical party had been skillfully organized by Thucydides - himself a competent speaker. Pericles had to face a strong opposition. The aristocratical party assumed a constant character, and its members regularly attended the public discussions, "sitting together in a particular section so as to be conspicuously parted from the Demos". ${ }^{39}$ As a result a strenuous contention arose between the party of Thucydides and that of Pericles. Thucydides accused Pericles of disgracing Athens in the eyes of the Delian confederacy, by having in reality usurped the treasure from

${ }^{36}$ See Thucyd., I.101-102.

${ }^{37}$ All things considered, argued Bulwer, "I believe, that if ever ostracism was justifiable, it was so in the case of Cimon - nay, it was perhaps absolutely essential to the preservation of the constitution" (Athens, vol. II, p. 338).

${ }^{38}$ History, 4:451.

${ }^{39}$ History, 4:501. 
Delos, under the pretence of greater security. The confederate funds were then used to decorate Athens, by new temples and costly statues, and not in prosecuting war against the Persians. Pericles replied in a way that satisfied Grote that Athens had fulfilled its promises; the Persian danger had ceased to be imminent. Yet Athens, according to Pericles, should have continued in accordance with the initial regulations to demand a tribute as a reserve sufficient to guarantee for the future the security of the confederacy. ${ }^{40}$ As the protectress of Hellenism, Athens, could, and even must, have employed the surplus for rendering itself supreme by improved fortifications, works of art, and cultural activity. Grote assumed that Pericles' intentions were principally directed towards exalting Athens into something greater than an imperial city. Pericles was imbued with "Pan-hellenic" sentiments, and he wished to make Athens "the centre of Grecian feeling, the stimulus of Grecian intellect, and the type of strong democratical patriotism, combined with full liberty of individual taste and aspiration".41

Pericles' response had not however succeeded in mitigating the oligarchical exasperation. The opposition became bitter and even violent, and the dispute would have produced disastrous results, had the provision of the Athenian constitution for the case of a contest between two opposite and nearly equal party-leaders been inoperative. ${ }^{42}$ A vote of ostracism was invoked and Thucydides accepted the

${ }^{40}$ See Plutarch, Pericles, XII.1-7.

${ }^{41}$ History, 4:504.

42 The regulations which attended the institution of ostracism show, Grote argued, that the Athenians respected individual life and property, History, 3:375-6. On these regulations see Aristotle, Athenian Constitution, XLIII.4; Plutarch, Arist. 7.4-6; Diod., XI.55.1-2, 87.1. Montesquieu maintained that in "Athens, where the legislator felt the extension and limits that he should give to his law, ostracism was a remarkable thing; 
challenge (or Pericles accepted it, since it is not clear which party first proposed the vote). Thucydides was banished and his party subsequently broken up.

Admittedly Grote made a good point in defending ostracism as a constitutional safeguard in a period when the state could not afford the presence of bitter controversies. Ostracism, he argued, was the institutional means of creating 'constitutional morality', i.e. willed obedience to the rules of democracy, and reverence for the constitution despite the intensity of party contests. The operation of ostracism removed dangerous party contests without an appeal to force. Grote's examination of ostracism, and his detailed historical explanation, was original, and anticipated in many respects the modern treatment of the subject. ${ }^{43}$ Sinclair has recently called ostracism the "safety valve of democracy", which "greatly minimised the danger of civil war and permitted the gradual, but surer, development of democratic sentiment". ${ }^{44}$ Finley and Ehrenberg also believed that ostracism became a structural part of Athenian politics, which was introduced as a safety device against excessive individual influence and the danger of tyranny. ${ }^{45}$

only a single person was subjected to it; there had to be such a great number of votes that it was difficult for any one to be exiled unless his absence was necessary" (The Spirit of the Laws, Cambridge 1989, Bk.29, ch. 7, p. 605). The person ostracized had to leave Athens within ten days and remain in exile for ten years, but he retained control of his property; see Hignett, History of the Athenian Constitution, p. 166. On the mildness of ostracism, see C.M.Bowra, Periclean Athens, London 1971, p. 19.

${ }^{43}$ Cf. Peter Karavites, "Cleisthenes and the Ostracism", Athenaeum, 52(1974):335.

${ }^{44}$ R.K.Sinclair, Democracy and Participation in Athens, Cambridge 1988, p. 220; similarly Donald Kagan, "The Origin and Purposes of Ostracism", Hesperia, 30(1961):400-1.

45 V.Ehrenberg, The Greek State, Oxford 1960, p. 58. M.I.Finley, "Athenian Demagogues", Past and Present, 21(1962):20-21. See also W.S.Ferguson, Greek Imperialism, London 1913, p. 60. R.J.Bonner (who praises Grote for "his marvelous insight into things Athenian") finds ostracism "a simple and sensible protective 
IV

\section{The Athenian Empire}

Gillies and Mitford dwelt on the so-called excessive severity of Athens towards its dependencies. These "unfortunate states"46 suffered from the "covetous ambition"47 of the Athenian people, inflamed by interested demagogues. Mitford obviously did not draw any distinction between imperial Athens, and the Athens as leader of the Delian League, a confederacy of Greek states allied against future Persian attack. ${ }^{48}$ Mitford tended to generalize, as, for example, taking the decree passed for the cruel punishment of Mytileneans (428 B.C.), as sufficiently indicative of the nature of the empire. ${ }^{49}$ "A soverein multitude ... would be likely to allow great indulgence to those ordered, without limitation by any precise instructions to extend empire and bring home money. ${ }^{150}$ Mitchell called attention to the hard fate of Scione, Melos and Aegina, as suggestive of the nature of the Athenian character. ${ }^{51}$

Grote argued that to identify the two periods was to commit a serious historical error. An impartial historian, Grote argued, should distinguish between the confederacy

measure" (Aspects of Athenian Democracy, California 1933, pp. 7, 58-63).

${ }^{46}$ J.Gillies, History of Ancient Greece, London 1792, vol. II, pp. 99-101.

${ }^{47}$ W.Mitford, History, vol. I, p. 554.

${ }^{48}$ Ibid., vol. I, p. 552.

${ }^{49}$ Ibid., vol. II, pp. 123-4. Cf. Grote, History, 5:164-177.

${ }^{50}$ Ibid., vol. IV, p. 240; see in addition, in the same vol. pp. 258-9.

${ }^{51}$ A.M.Mitchell, The Comedies of Aristophanes, London 1820, vol. I, p. cli. 
of Delos, with Athens as president, and the Athenian empire which grew out of it. ${ }^{52}$ The transition from the Athenian hegemonia to the Athenian arche - as Thucydides calls it ${ }^{53}$ - was doubtless gradual, but it had been completed, Grote asserted, before the thirty years' truce (i.e. before 444). It can be reasonably inferred, he continued, that the first ten years of the Athenian leadership must have been years of active warfare against the Persians. ${ }^{54}$ Athens legitimately took the presidency since its maritime power was by far the greatest. And even after the battles of Plataea and Mycale, organized maritime activity was of vital importance. The Persians were driven away, but not the recollection of their cruelties, or the likelihood of a new coordinated attack.

It was initially stipulated that the members of the Delian synod would have provided personal military service. But after a few years many members became weary of personal service. Here Grote marked the first alteration in the relations of the allies. The members themselves prevailed upon the Athenians to substitute moneypayments for personal service. Henceforward the position of Athens as well as the feelings of its citizens changed. The confederate states became ultimately weary even of paying their tribute, and they endeavoured to separate themselves from the alliance. But the Athenians repressed their attempts, and these states became their subjects. This alteration in the Delian alliance took place gradually so that it is difficult to determine

${ }^{52}$ History, 4:379-81. On this distinction see Meiggs, The Athenian Empire, p. 173; M.F.McGregor, The Athenians and their Empire, Vancouver 1987, pp. 167-8; and F.J.Frost, Democracy and the Athenians, New York and London 1969, chronological table.

\footnotetext{
${ }^{53}$ Thucyd., I.97-99.

${ }^{54}$ History, 4:383.
} 
when the changes began. The allies, Grote asserted, "slid unconsciously into subjects, while Athens, without any predetermined plan, passed from a chief into a despot". 55 Yet Grote's historical sense did not allow him to acquit Athens of its unseemly proceedings. There were two just causes of the growing unpopularity of Athens. First, the Athenians acted evidently against the Greek instinct of political autonomy: the principles and experience of Greek political life were against an alliance of this character, ${ }^{56}$ secondly, Athens, having defeated the Persians, began to employ the Delian alliance to promote its predominance throughout Greece. Nevertheless Grote still maintained that Athenian predominance, and the enforcement of its maritime potentiality, was in fact necessitated to protect the Aegean sea, since the Persians enjoyed at that period the maximum of their power. Further, historians in Grote's view, were not justified in overstressing the defects and unpopularity of the Athenian empire. Compared with the Spartan empire of the fourth century, with its cruel and omnipotent harmosts, Athenian policy was superior. ${ }^{57}$ Actual discontent among the citizens in the subject-allied cities was limited: "the feeling towards Athens was rather indifference than hatred". ${ }^{58}$ Small groups of over-ambitious men, usually aristocrats,

${ }^{55}$ History, 4:388. "We did not gain this empire by force", says Thucydides' Pericles, "It came to us at a time when you were unwilling to fight on to the end against the Persians" (I.75). "We can believe", maintains Meiggs, "that Aristides had a shrewd idea of the benefits that a league under Athenian leadership could bring to Athens, but we should not be too cynical ... It was the allies who had most to gain from Athenian leadership" (The Athenian Empire, pp. 42-3, emphasis added).

${ }^{56}$ History, 4:489, 517. As Bury remarked, "The sovereign city-state was the basis of the civilised Hellenic world" (History of Greece, p. 341); also, Ehrenberg, The Greek State, p. 94.

${ }^{57}$ History, 4:523, 5:4-5, 7:358-9.

${ }^{58}$ History, 4:390. G.E.M. de Ste Croix went even further and argued that, "the general mass of the population of the allied (or subject) states, far from being hostile 
were the instigators of actual revolts. ${ }^{59}$ In the case of the Melos revolt in 416, which ended with "one of the grossest and most inexcusable pieces of cruelty combined with injustice which Grecian history presents to us",60 the Melian leaders admitted the envoys, sent by Athens, to a private conversation, and disregarded the feelings of the general assembly. ${ }^{61}$ In the case of the revolt in Chios, which began against the will of the general population, Grote remarked:

Contrary to what is commonly intimated by historians, we may observe, first, that Athens did not systematically interfere to impose her own democratical government upon her allies ${ }^{62}$ - next, that the empire of Athens, though upheld mainly by an established belief in her superior force, was nevertheless by no means odious, nor the proposition of revolting from her acceptable, to the general population of her allies. ${ }^{63}$

And it was not only that the general population was commonly averse to revolt; further, as the case of Samos has shown, the people regarded the alliance with Athens as the primary security against local oligarchical cruelties. ${ }^{64}$

Grote justified his 'unorthodox' sympathy towards the Athenian empire, which

to Athens, actually welcomed her dominance and wished to remain within the empire" ("The Character of the Athenian Empire", Historia 3(1954):1, emphasis added).

${ }^{59}$ History, 4:518-20.

${ }^{60}$ History, 5:512.

${ }^{61}$ History, 5:507; see Thucyd., V.84.

62 Thirlwall claimed that Athens had generally encroached on the rights of her subjects by affecting their forms of government. See History of Greece, vol. III, pp. 47-8. Athens, Meiggs argues, "was not doctrinaire in her relations with allies; there were oligarchies as well as democracies among them" (The Athenian Empire, p. 54). See also McGregor, The Athenians and their Empire, p. 169; J.K.Davies, Democracy and Classical Greece, Fontana 1978, p. 86. Aristotle however, asserted that "the Athenians destroyed oligarchies everywhere" (Politics, V.vi.9 - 1307b.23).

${ }^{63}$ History, 6:203.

${ }^{64}$ History, 6:208-9. 
enjoyed its greatest glory during the mature democratic administration of Pericles, by arguing first, that the maritime protection of the Aegean proved doubtless advantageous to the development of free and unobstructed trading relations. These commercial relations were not confined to narrow localities, but they also reached western regions..$^{65}$ Secondly, and most importantly, the empire aided the diffusion of democratic consciousness among its subjects, and fostered a deep aversion to tyrannical regimes. ${ }^{66}$ Thirdly, the citizens of the subject allies were not subjected to positive hardships. ${ }^{67}$ Grote did not find sufficient evidence showing that the Athenians demanded excessive and increasing tribute from their dependencies. ${ }^{68}$ The people in the subject-allied states had been well aware of the hazardous side in case the status quo would have completely changed. They would have been exposed to new enemies against whom Athens had hitherto protected them, or if not to them, to the aggravated ambition of their own oligarchies. In effect, according to Grote, the bulk

${ }^{65}$ History, 4:497. K.R.Popper believes that "the most powerful cause of the breakdown of the closed society was the development of sea-communications and commerce ... These two, seafaring and commerce, became the main characteristics of Athenian imperialism" (The Open Society and Its Enemies, London 1952, vol. I, p. 177).

${ }^{66}$ History, 6:507. 191.

${ }^{67}$ Similarly, Alfred Zimmern, The Greek Commonwealth, Oxford 1931, pp. 189,

${ }^{68}$ History, 4:490-4, 520. Cf. Boeckh, Public Economy of the Athenians, pp. 51920. Grote's scepticism has been proved well grounded. Meiggs shows, using the Athenian Tribute Lists (ed. B.D.Meritt, H.T.Wade-Gery, and M.F.McGregor, 4 vols, Cambridge and Princeton 1939-53), that not only the Athenians did not increase the amount of tribute, but they also often proceeded to reduce it. We may doubt, according to Meiggs, "whether before the Peloponnesian War the allies were required to pay more than they could comfortably afford" (The Athenian Empire, pp. 182, 258, and 265); similarly Bury, History of Greece, p. 328; A.W.Gomme, "The Working of the Athenian Democracy", More Essays in Greek History and Literature, Oxford 1962, p. 178. 
of the citizens in the subject cities were heartily loyal to Athens. ${ }^{69}$ Finally, Athens exercised legal authority over its allies. Any dispute among the subject-allies, or among their citizens, was brought for trial before the Athenian courts. Though this practice must have created a great deal of discontent, it also tended, in Grote's view, to secure the administration of justice to the "weakest and most defenceless" citizens. $^{70}$ Far from being an unjust treatment towards its subjects, it allowed for equality before the law, thus securing the absence of discrimination between Athenians and their subjects, at least in what concerned the administration of justice. ${ }^{71}$ As the practice went on, it afforded protection against misconduct of Athenian citizens who resided in their regions (Kleruchs), or Athenian officers. ${ }^{72}$ Under Sparta the general rule followed by the harmosts and Dekarchies was to put to death whomever they liked, without any trial at all. Grote pointed out the case of the harmost Oreus in Euboea, whose injustice and atrocities remained unpunished. Indeed we know, maintained Grote, "that these Spartan authorities would grant no redress, not merely against harmosts, but even against private Spartan citizens, who had been guilty of

${ }^{69}$ History, 4:520. Ste Croix is clearly anticipated by Grote. See "The Character of the Athenian Empire", pp.16, 6, 10. See also, Jacqueline de Romilly, Thucydides and Athenian Imperialism, Oxford 1963, pp. 376-7.

${ }^{70}$ History, 4:522; similarly L.B.Carter, The Quiet Athenian, Oxford 1986, p. 31.

${ }^{71}$ Similarly see A.H.M.Jones, "Athenian Democracy and its Critics", in Athenian Democracy, Oxford 1969, pp. 70-1. This measure was generally attacked by historians who preceded Grote. See, e.g., A.H.L.Heeren, A Sketch of the Political History of ancient Greece, Oxford 1834, p. 133; Thirlwall, History of Greece, London 1836, vol. III, p. 48; Young, History of Athens, p. 376; Bulwer, Athens, vol. II, p. 474; Thomas Mitchell, "Greek Courts of Justice", Quarterly Review, 33(1826):333n.

${ }^{72}$ History, 4:526-7. 
gross crime out of their own country". ${ }^{73}$ Whereas Athens had deprived its subjectallies of their autonomy, but not of the administration of justice, Sparta, in effect, enslaved them, inflicting upon them unnecessary suffering. ${ }^{74}$

The Athenian empire, that remarkable phenomenon in Greek political history, was broken up, after the disaster in Sicily (413 B.C.). "During the period of its integrity", Grote argued "it is a sight marvelous to contemplate, and its working must be pronounced ... to have been highly beneficial to the Grecian world". ${ }^{75}$ In conclusion, Athens, as an imperial state demanded obedience, but it never overlooked the duties and the responsibility that its position entailed. Athens had given not only prosperity to its subject-allies, but further liberation from the yoke of local tyrannies and long-established oligarchies. As long as the Athenian maritime power was actively present in the Aegean it guaranteed the impossibility of any unpredictable Persian invasion. With the empire's decline the door opened to Persian interference and corruption, and at last facilitated the reign of Macedonia - which Grote so strongly lamented. To incorporate so many disparate states into one system, with specifically common rules and tasks, "Nothing but the genius, energy, discipline, and democracy of Athens could have brought ... about" ${ }^{76}$ The overthrow of this 'pan-hellenically' motivated empire, never to be replaced by the poorly qualified Spartans, ${ }^{77}$ ultimately brought the universal ruin of Greek independence.

\footnotetext{
${ }^{73}$ History, 7:358; see also pp. 355-60.

${ }^{74}$ History, 7:366-8.

${ }^{75}$ History, 6:506.

${ }^{76}$ History, 6:508.

${ }^{77}$ See, BL Add. MS 29,514 (1818-1831), fo. 455.
} 


\section{Cleon and the Role of Demagogues in Ancient Democracies}

Grote's defence of the demagogue Cleon was of equal novelty. ${ }^{78}$ In this respect he attempted to vindicate Cleon against Thucydides and Aristophanes. ${ }^{79}$ Thucydides was regarded a 'sacred' authority by English historians in the eighteenth century. ${ }^{80}$ Here again Grote's defence of Cleon was an anticipation of the modern treatment of the subject. But being advanced for the intellectual climate of his epoch, it met with hostile criticisms. ${ }^{81}$

Cleon belonged, according to Grote's analysis of Athenian life during the Peloponnesian war, to a new class of politicians, those who emerged from the world of business, trade and manufacture, and were the major political antagonists of the privileged by birth. $^{82}$ Enrichment by trade was not enough, however, to attain preeminence. To distinguish themselves in this area was not an inconsiderable advantage; but it, alone, could have easily proved unavailing. These new politicians

${ }^{78}$ Thirlwall's 'moderation' did not save him from falling into contradictions, as for instance in the case of Cleon; see History of Greece, vol. IV, pp. 216-7; cf. vol. III (1836), p. 186.

${ }^{79}$ Aristotle also pointed out that Cleon "is thought to have done the most to corrupt the people" (Athenian Constitution, xxviii.3, and xxviii.4). For Cleon's "disgusting boldness" and his "rapacity and fierce ... effrontery", see Plutarch, Nicias, II.2-3.

${ }^{80}$ See, e.g., Stanyan, Grecian History, vol. I, p. vii; and J.P.Mahaffy's remarks, A History of Greek Literature, London 1910, vol. II, Part I, p. 106. As A.G.Woodhead argues, in doing so scholars robbed him of his humanity. See "Thucydides' Portrait of Cleon", Mnemosyne, 13(1960):292.

${ }^{81}$ The most furious article was written by Richard Shilleto. See his Thucydides or Grote?, Cambridge 1851.

${ }^{82}$ See Ehrenberg, From Solon to Socrates, p. 274; see also p. 460.n.33: "Cleon has found defenders, ever since Grote", emphasis added. 
had to be competent enough in speech and intellectual capacity in order to gain the general confidence of the assembly. Cleon was one of them, and his own position was even more interesting since he combined "an aristocratical position with a strong and genuine democratical sentiment" ${ }^{83}$ Thucydides and Aristophanes have described him in the harshest terms. For Thucydides, Cleon was remarkable for the "violence of his character". ${ }^{84}$ Aristophanes attacked Cleon vigorously in the Knights. He called him "the greatest rogue and liar in the world", and the most corrupt and rapacious. ${ }^{85}$ Cleon was represented as the embodiment of the ruinous influences that spoilt the internal concord of Athenian policy, and transformed the "self-denying Republic of the Persian war into the unpopular and tyrannical Republic of the Peloponnesian war". ${ }^{86}$ Agard has reasonably inferred that "If Cleon had been guilty of the crimes of which Aristophanes accused him he would certainly have been indicted before a court". ${ }^{87}$

Thus Cleon's image came to us darkened both by Aristophanes and Thucydides. The old criticisms were repeated uncritically by the eighteenth-century historians. Stanyan in calling him "rash, arrogant and obstinate, contentious, envious

${ }^{83}$ History, 5:166.

${ }^{84}$ Thucud., III.36. Thucydides never referred to Cleon's name without some unfavourable insinuation; see e.g., IV.21, 27-8.

${ }^{85}$ Aristophanes, Knights, 45: "panourgotaton kai diabolotaton tina"; see also, 75, 626-9, 758.

${ }^{86}$ B.B.Rogers, The Comedies of Aristophanes, London 1910, vol. I, p. xxvii.

${ }^{87}$ Agard, What Democracy Meant to the Greeks, p. 187. 
and malicious, covetous and corrupt", exhausted all his depreciatory adjectives. ${ }^{88}$ Even the calm account of Thirlwall rendered him a "master of impudence", who professed himself the friend of the poor, but "cherished their envy and jealousy of the rich, and accustomed them to consider their personal interests as the sole end of the state". ${ }^{89}$ The demagogues were indiscriminately presented as motivated by selfinterest, and the desire to become the most powerful men in the poleis both in political influence and wealth. ${ }^{90}$ To that end they deceived the multitude, they oppressed the nobles, and paid no regard to the dictates of humanity. Grote, in his turn, went on to argue, that first Cleon's policy resembled that of Pericles, and at any rate it was typical of an imperial rule; and secondly, that the demagogic function per se was of great importance in the newly-born democracies.

Grote proceeded to justify the Cleonean policy, at least on the two occasions where it was submitted to severe attack. The first is the well known case of the revolt of Mytilene. ${ }^{91}$ Cleon advised the Athenian assembly that a decision should be taken to the effect that all the adult males of this disloyal state should be killed, and the women and children sold as slaves. Cleon at first succeeded in persuading the Athenians, but the next day the discussion was reopened and a milder decision was

${ }^{88}$ Stanyan, Grecian History, vol. I, p. 379. Goldsmith copied Stanyan, Grecian History, London 1774, vol. I, pp. 244-5. Mitford repeated the criticism; see History, vol. II, p. 123. Young, criticized him as "a braggart, who had talked himself into office by depreciating real merit, and by lauding his own, and that of the people" (History of Athens, p. 257).

${ }^{89}$ Thirlwall, History, vol. III, pp. 186-7. See also C.A.Wheelwright, The Comedies of Aristophanes, Oxford 1837, 'Preliminary Observations upon the Knights', p. 290.

${ }^{90}$ See M.I.Finley, "Athenian Demagogues", Past and Present, 21(1962):4.

91 The whole discussion can be found in Thucyd., III.36-50. 
taken. Yet, it should be emphasized that, in Grote's view, "The violent Kleon would on this occasion find in the assembly an audience hardly less violent than himself, and would easily be able to satisfy them that anything like mercy to the Mytilenaeans was treason to Athens".92

Sheer political expediency cannot, of course, justify such a ruthless decision. But Cleon was not alone in his determination. The Athenians, Grote argued, had sufficient reason to feel indignant against Mytilene. Having no ground of complaint against Athens, as they themselves admitted before the Peloponnesians at Olympia, they justified their revolt by invoking possible oppression in the future. ${ }^{93}$ More irritating, however, was their decision to revolt against Athens at that particular moment, when the Athenians were suffering a horrible pestilence, invasion, and the high cost of war. ${ }^{94}$ In addition, they had been the first to invite a Peloponnesian fleet across the Aegean, and to warn them of the 'imminent dangers' of Athenian imperialism. "Nothing more than this", Grote contended, "would be required to kindle the most intense wrath in the bosom of an Athenian patriot". 95 Finally, Cleon's proposal for their punishment was not extraordinary, but simply reflected the severest penalties imposed by the generally accepted laws of war in ancient Greece.

${ }^{92}$ History, 5:169.

${ }^{93}$ Thucyd., III.12.

${ }^{94}$ Thucyd., III.3. Ste Croix shows that even the Mytilenian revolt was conducted by the governing oligarchy, the people being friendly to the Athenians. See "The Character of the Athenian Empire", p. 4.

${ }^{95}$ History, 5:169. A.G.Woodhead similarly justifies the Cleonean policy respecting Mytilene: "Granted the premise of to xympheron and its importance, there is no reductio ad absurdum, nothing fallacious or self-condemnatory in the facts of Cleon's proposals as they emerge" ("Thucydides' Portrait of Cleon", Mnemosyne, 13(1960):300). 
Next comes the case of Sphacteria. Cleon, falling victim in the manoeuvres of his political enemies (especially those who belonged to aristocratic clubs, Nikias among them), was appointed as general. The object of the enterprise, namely to take as prisoners the Spartans of the blockaded Sphacteria, appeared extremely hard to Nikias and other eminent generals. The Spartans were supposed to resist to the point of death (as they had done in Thermopylae), and therefore the quarrel with Sparta would have been inflamed anew. Nevertheless the appointment of Cleon as general appeared highly advantageous to his opponents. They could expect but two things, both positive: either to get rid of Cleon, most likely in their anticipations, or to capture the island with the Spartans killed or alive. ${ }^{96}$

It should be noted however that all these steps might have been avoided had the Athenians accepted the proposals of Sparta for peace. But at the urging of Cleon their plans were rejected as unsatisfactory. The rejection of the peace-terms with Sparta had been vigorously criticized by the eighteenth-century historians. This "arrogant demagogue", in Gillies' opinion, succeeded in the rejection of an "advantageous peace with Sparta". ${ }^{97}$ Grote persistently denied that the terms proposed by Sparta were, in any sense, profitable to the Athenians. On the contrary, they were "discreetly calculated" for its own purposes. ${ }^{98}$ Grote described the Athenian

${ }^{96}$ History, 5:253-4. This is what Thucydides himself admitted (IV.28).

${ }^{97}$ Gillies, History of Greece, vol. II, pp. 281, 286. Montagu argued that this "noisy, seditious" and "turbulent" demagogue, brought the ruin of Athens (Reflections, p. 90). Mitford believed that this "turbulent orator" encouraged the Athenian "despotic multitude" to decide the fate of the Spartans at Sphacteria, "the most meritorious of the Greek nation" (History, vol. II, pp. 168 and 185).

${ }^{98}$ History, 5:244. See Thucyd., IV.21, for the reasonable terms counterproposed by Cleon (having in mind Athens' advantageous position) in order to accept the Spartan peace proposals. 
sentiments and reaction, as well as the whole proceedings until the dismissal of the Lacedaemonian envoys. The Athenians' only mistake was their "over-estimation of the prospective chances arising out of success"; but nobody is justified in assigning this event to democratical folly. Over-estimation of their chances "to a degree more extravagant than that of which Athens was now guilty, is by no means peculiar to democracy". ${ }^{99}$ Cleon demanded the restoration of lost conquests in exchange for the soldiers in Sphacteria. This is quite reasonable for a state that enjoyed, at this particular juncture, a considerable number of practical advantages. Cleon's vehement conduct is not to be blamed: "On the present occasion he doubtless spoke with the most genuine conviction; for he was full of the sentiment of Athenian force and Athenian imperial dignity, as well as disposed to a sanguine view of future chances. ${ }^{100}$ Cleon in the end carried on successfully the enterprise in Sphacteria, and became the author of the most important success of Athens throughout the Peloponnesian war. ${ }^{101}$ Nikias, and those who were attached to the Spartan ideal, would have betrayed Athens, and agreed to a peace disadvantageous to it.

Cleon, in Grote's view, being an opponent of peace, derived no personal interest, as Thucydides wants us to believe. ${ }^{102}$ The peace finally concluded in $424-3$

${ }^{99}$ History, 5:247.

100 History, 5:245. See also BL Add. MS 29,514 (1818-1831), fo. 336: "Thucydides seems to consider that the death or disgrace of Cleon would have been a greater benefit to Athens than the victory and capture of the Laced[aemonia]ns at Sphacteria."

\footnotetext{
${ }^{101}$ History, 5:257.

${ }^{102}$ History, 5:368.
} 
(under Nikias' auspices) was ill-judged and highly disadvantageous to Athens. ${ }^{103}$ At this time, Athens should have prosecuted the war in Thrace, preventing Brasidas from advancing further. On the other hand, Grote maintained that the policy recommended by Cleon was in fact entirely compatible with that of Pericles. ${ }^{104}$

As to the statements given by Thucydides and Aristophanes on the policy and character of Cleon, Grote attached little value. Both writers, Grote believed, had a bitter personal grudge against the demagogue. ${ }^{105}$ With regard to Thucydides' hostility towards Cleon, Grote reminded his readers of the case of Amphipolis. Athens, due to Thycydides' negligence, who had been appointed general in the region, lost Amphipolis, and thereby sustained a most serious and irreparable blow. He was subsequently banished on the proposal of Cleon ${ }^{106}$ - incurring justly, in Grote's view, the verdict of guilty, for the place was of importance for the advancement of the Athenian strategic plans. Amphipolis, being situated near the mouth of the Strymon, enabled the Athenians to check the east-west route. ${ }^{107}$ On the other hand, to judge

${ }^{103}$ History, 5:345.

${ }^{104}$ History, 5:369, 372. On the coincidence of Cleon's and Pericles' policies see the remarks of Bury, History of Greece, p. 416; J.de Romilly, Thucydides and Athenian Imperialism, Oxford 1963, p. 166; W.R.Connor, The New Politicians of Fifth-Century Athens, Princeton 1971, p. 134; Woodhead, "Thucydides' Portrait of Cleon", p. 311. Cf. Allen B.West, "Pericles's Political Heirs", Classical Philology, 19(1924):136, 137n.1.

${ }^{105}$ See also, G.W.Cox, Lives of Greek Statesmen, New York 1886, pp. 131, 138; Davies, Democracy and Classical Greece, p. 112.

${ }^{106}$ History, 5:328-9. See also, B.B.Rogers, The Knights of Aristophanes, London 1910, p. xxvii; and Richard A.Bauman, Political Trials in Ancient Greece, London and New York 1990, p. 60.

${ }^{107}$ See Ehrenberg, From Solon to Socrates, p. 245; and Meiggs, The Athenian Empire, p. 195. 
Cleon on the basis of the Knights of Aristophanes is as fair as judging Socrates on the testimony of the Clouds. ${ }^{108}$ Cleon indicted Aristophanes for wrongdoing towards the Athenians and their Council, because he satirized them when foreigners were present, at the Great Dionysia.

The defence of Cleon, however, must be seen in the context of the role and function of the demagogues in ancient democracies. It may be conceded that Cleon was a man of fierce political antipathies, a bitter speaker endowed with a violent temper, and occasionally dishonest in his relations with political rivals; but, Grote suggested, "These are qualities which, in all countries of free debate, go to form what is called a great opposition speaker". ${ }^{109}$ Cleon was exceptionally qualified for this role, and in the course of his life he employed his abilities often in defending those who had suffered wrong. ${ }^{110}$ But most importantly he helped the people to emancipate themselves from the political control of the nobles who possessed real administrative power. ${ }^{111}$ Like Cleon the Syracusan Athenagoras was an opposition speaker. They were popular orators of their native states; and their functions were

${ }^{108}$ History, 5:392-4. Regarding Aristophanes' hostility towards Cleon, see also Acharnians, 377-82. Meiggs gives an explanation of his hostility to Cleon, in The Athenian Empire, p. 256.

${ }^{109}$ History, 5:395.

${ }^{110}$ Sinclair recently affirmed that the word 'demagogos', when first used, "was probably neutral or even complimentary" (Democracy and Participation in Athens, $\mathrm{p}$. 37n.78). The same does Connor, adding that even "in the fourth century one can speak of "good demagogues without seeming excessively oxymoronic" (The New Politicians, p. 110).

111 "Demagogues were radical, in the sense of attacking aristocratic pretension and of being merciless towards aristocratic incompetence" (Davies, Democracy and Classical Greece, p. 115). 
analogous to those of opposition leaders. ${ }^{112}$ These men have been presented by historians as turbulent and warlike, whereas they were fervent popular speakers, and, as the case of Athenagoras clearly shows, opposed to war. The demagogues had nothing to gain from the prosecution of war. The Athenian Cleophon, however, like Cleon earlier, managed to convince the assembly to reject the peace terms proposed by Sparta in 410 B.C. But Cleophon, in Grote's judgement, was not wrong. After the restoration of democracy (succeeding the oligarchy of the Four Hundred), and following the victorious battle of Kyzicus, the distressed Spartans proposed peace with Athens. Cleophon opposed the proposals for peace which in the end were rejected. Historians, Grote believed, attacked Cleophon because they were unable to abstract from their minds the final chapter of the war: in 410 B.C. new opportunities were arising for the Athenians. Cleophon acted patriotically, having nothing personal to gain. ${ }^{113}$

Cleon's major rival was Nikias. Gillies praised his "superior rank"; posterity "will for ever lament the fate of Nicias the most pious, the most virtuous ... man of the age in which he lived". ${ }^{114}$ Nikias is the man, in Grote's view, who brought about the ruin of Athens. ${ }^{115}$ And that this man caused the ruin of Athens is neither accidental, nor destitute of political lessons. It shows how an imposing respectability,

${ }^{112}$ History, 6:24-5.

${ }^{113}$ History, 6:347.

114 Gillies, History, vol. II, pp. 402, 411; see also Mitford, History, vol. II, pp. 380-81, 385. "All wise and compassionate men could not forbear shedding tears at the tragical fate of ... Nicias, who, of all men of his time, seemed least to merit so ignominious and untimely an end" (Goldsmith, Grecian History, vol. I, p. 304).

${ }^{115}$ History, 6:502-8. 
emanating from certain characteristic qualifications that generally attract the admiration of the people, can create illusions, and result in fatal decisions. For Grote, the Athenians had shown over-confidence in Nikias, and this was the greatest mistake they ever committed. ${ }^{116}$ Their dreams, ambitions and their defences perished in the harbour of Syracuse. This was the result of their inability to anticipate (or simply to believe) that a man like Nikias could show so much imprudence and incapacity. This man "whose flagrant incompetency could bring such wholesale ruin upon two fine armaments entrusted to his command, upon the Athenian maritime empire, and ultimately upon Athens herself, must appear on the tablets of history under the severest condemnation". ${ }^{117}$ Not even the most eloquent demagogue would have created this fatal and blind over-confidence and fostered these unreasonable expectations.

Thus Grote contrasted the demagogues, who performed their function spiritedly but seldom contrary to the established constitution, with the charismatic politicians, whose personal ability to inspire respect and enthusiasm could easily lead to the circumvention of the law. Contrary to those who had argued that the demagogues caused the corruption, the misfortunes, and the ultimate decline of the democratical states, Grote argued that the demagogues were the living organs of democratic institutions. ${ }^{118}$ The demagogues rendered great service to democracy and often resisted oligarchical conspiracies. Hyperbolus, for instance, the Athenian exile who resided in Samos during the attempts of Peisander and his partisans to subvert the

\footnotetext{
${ }^{116}$ History, 6:183-4.

${ }^{117}$ History, 6:182.

${ }^{118}$ History, 6:271.
} 
Samian democracy, resisted their plans at the cost of his life. Hyperbolus, according to Grote, "represented the demagogic and accusatory eloquence of the democracy, the check upon official delinquency; so that he served as a common object of antipathy to Athenian and Samian oligarchs". 119

Since Grote the historians' attitude towards the Greek demagogues has considerably changed. Bonner maintains that the demagogues were competent speakers and men of substance, worthy representatives of the ruling class in Athens of the late fifth century. Enough has been said to show, proceeds Bonner, "that these demagogues were not the disreputable rascals that Aristophanes represented them to be". ${ }^{120}$ Walker accepts as fundamentally true Grote's argument that a demagogue need not and usually did not hold any office. A demagogue was merely a member of the assembly, like any one else. Yet, Walker regards this particular aspect of the demagogues' position, as the really fatal defect in the Athenian system. Whereas the Athenian constitution provided sufficient means for checking official responsibility, it was not feasible to ascribe responsibility to a person who did not hold any office, and whose proposals were necessarily entrusted to others. ${ }^{121}$ Finley answered (and it is important that he opened his article with two contrasting quotations, one from Thucydides and another from Grote), that the demagogues, granted the various legal

${ }^{119}$ History, 6:257.

${ }^{120}$ R.J.Bonner, Aspects of Athenian Democracy, California 1933, p. 56.

${ }^{121}$ E.M.Walker "The Periclean Democracy", in Cambridge Ancient History (ed. J.B.Bury, S.A.Cook, F.E.Adcock), Cambridge 1927, vol. V, pp. 108-9. Hignett, similarly, points out that the demagogue was not an ex officio member of the boule. "This divorce between influence and responsibility was an ominous development, destined to prove one of the principal causes for the decline of Athens" (History of the Athenian Constitution, p. 264). 
provisions of the Athenian system, could not renounce responsibility for their proposals. "It was part of the Athenian governmental system that, in addition to the endless challenge in the Assembly, a politician was faced, equally without respite, with the threat of politically inspired lawsuits." ${ }^{.12}$ For Finley the demagogues, "were a structural element in the Athenian political system"; without them the system could not function at all. "We cannot praise and admire the achievement of two centuries", argued Finley, "and at the same time dismiss the demagogues who were the architects of the political framework and the makers of policy". ${ }^{123}$ Cleon and the demagogues have also found defenders in Ste Croix ${ }^{124}$ and Connor. Connor argues that Cleon deserves a high place in the history of the development of politics. "He was the master of a new technology of political power, an innovator and a perfector. His accomplishments, like any great technological change, are a break with past traditions and ways, and a source of imitation and emulation in the future."125 For those who became ardent defenders of the Athenian democracy, and whose accounts Grote would have accepted with the greatest satisfaction, like Glover and Jones, the demagogues were fruitful offsprings of liberty and free speech. Glover points out that Cleon was a practical politician and a reliable democrat, whom people trusted and understood.

${ }^{122}$ M.I.Finley, "Athenian Demagogues", Past and Present, 21(1962):14.

${ }^{123}$ Ibid., p. 23; see also p. 19.

${ }^{124}$ Thucydides, maintains Ste Croix, "detested Cleon and could not bring himself to be just to him ... If these 'demagogues' were really mere flatterers of the demos, it is strange that of the six whose names were mentioned above, at least four or five should have died violent deaths" ("The Character of the Athenian Empire", p. 35).

${ }^{125}$ Connor, The New Politicians, p. 119. 
Cleon was "a product of Democracy". ${ }^{126}$ Jones remarks that Thucydides was strongly prejudiced against Cleon, adding that "later generations did not share Thucydides' low opinion of him". ${ }^{127}$

\section{VI}

\section{The Athenian Character}

The moral character of the Athenians was severely criticized by eighteenthcentury historians. Montagu highlighted many instances of the levity "of that unsteady people", whose policy was dictated by private passions, envy, and unrestricted ambition. ${ }^{128}$ In Mitford's judgement Athenian policy was directed through a complex system of party-rivalries, and by a government incapable of any "steddiness, or even secure against acts of madness". ${ }^{129}$ Mitford spoke in harsh terms of the Athenian judicature, which in his opinion, afforded no securities against the violence of the multitude. He even went so far as to identify the Athenian system with Turkish despotism. ${ }^{130}$ Athenian life under democracy appeared to Mitford to be no better than the rule of a mob, which "delighted in accusation, prosecution, and the whole

${ }^{126}$ T.R.Glover, Democracy in the Ancient World, Cambridge 1927, p. 68.

127 Jones, "Athenian Democracy and its Critics", pp. 63-4.

${ }_{128}$ Montagu, Reflections, pp. 83-4; similarly, J.A.Cramer, A Geographical and Historical Description of Ancient Greece, Oxford 1828, vol. II, p. 296.

129 Mitford, History, vol. II, p. 517; also, vol. III, p. 88 for the "irremediable unsteddiness" of the Athenian constitution.

${ }^{130}$ Ibid., vol. III, pp. 18-21; also vol. IV, p. 232. Thirlwall, as usual, maintained a 'balanced' position. If the Athenian character, he argued, "was fickle, passionate, often unjust, it was still always capable of mercy and pity" (History of Greece, p. 227). 
business of sycophancy". ${ }^{131}$ For Mitchell the daily business of the law-courts enabled the poor to get an easy salary, offering themselves as "informers, as witnesses, or as judges; and the idle and the ingenious found in them a perpetual source of amusement". ${ }^{132}$

Grote defended the Athenians against these accusations, and contended that their observance of the laws, as well as their attachment to the principles of constitutional democracy were steady and persevering. Earlier historians insisted on the condemnation of Miltiades as an example of the Athenians' fickleness and ingratitude. ${ }^{133}$ Grote defended the Athenians, and condemned Miltiades for allowing himself to be corrupted by success and flattery. ${ }^{134} \mathrm{He}$ was flattered by the admiration and deference paid to him by his fellow-citizens, and became arrogant and ambitious beyond measure.

The Athenians, whose sentiments were expressed loudly and openly, and with every sign of sincerity, were not unconscious of the significance of their decisions. Democracy, according to Grote, permitted the free expression of a variety of opinions. The diverse opinions helped to balance extreme judgements: people learned to respect each other's ideas and convictions; and, most importantly, they "acquired a certain 204-5.

${ }^{131}$ History, vol. III, pp. 476-7. See also, Stanyan, Grecian History, vol. II, pp.

132 T.Mitchell, "Greek Courts of Justice", Quarterly Review, 33(1826):354.

${ }^{133}$ Even Cicero finds in the maltreatment of Miltiades and Themistocles revealing instances of "the fickleness and cruelty of Athens toward her most eminent citizens", Republic, I.iii.5. Cicero's judgement was repeated by Goldsmith, Grecian History, vol. I, p. 115; and Stanyan, Grecian History, vol. I, p. 229. Cf. Bulwer, Athens, vol. II, p. 13.

${ }^{134}$ History, 4:59-60. 
practical consciousness of their own liability to error". ${ }^{135}$ Considering the effect of the popular assemblies on the character of people in ancient democracies, Grote remarked that every man could become "accustomed to hear the functionaries of government freely censured and overhauled: every man when he felt himself wronged, stood a good chance of being able to create general sympathy, and looked to this sympathy for redress". ${ }^{136}$ Thus revenge was not connected with unnecessary infliction of pain and suffering. Further, Grote believed that the fickleness "which has been so largely imputed to the Athenian democracy ... is nothing more than a reasonable change of opinion on the best grounds". ${ }^{137}$ Far from being fickle and unsteady, the Athenians were attached to their constitution. In no part of the world, Grote contended,

has this sentiment of constitutional duty and submission to the vote of a legal majority been more keenly and universally felt than it was among the citizens of democratical Athens. ${ }^{138}$

It was this characteristic of the Athenians that Antiphon used to destroy their constitution and establish the oligarchy of the Four Hundred. But in Grote's view, the conduct of the Athenians on each occasion after the restoration of democracy (in 411 and 403), was admirable, since it proved that despite the moral and practical degradation to which they had been subjected, they did not give way to their passion for vengeance. They demonstrated that the cardinal lesson of democracy - to hold

\footnotetext{
${ }^{135}$ History, 4:63.

${ }^{136}$ BL Add. MS 29,517 (1826-1832), fo. 38.

${ }^{137}$ History, 4:61.

${ }^{138}$ History, 6:270. Similarly, Gomme, "The Working of the Athenian democracy",
} p. 192. 
sacred the inviolability of law and justice - was well inculcated in their minds. ${ }^{139}$ Their conduct, an astonishing event in history, far from being accidental, or imposed by external necessities, "depended upon permanent attributes of the popular character". ${ }^{140}$

But what about the illegal judicial proceedings after the battle of Arginousae? ${ }^{141}$ On this occasion, as well as on the occasion of the mutilation of Hermae, Grote revealed a dark side of Athenian society. The six generals were convicted of not taking all the necessary steps to save their wounded and drowning countrymen. ${ }^{142}$ Regardless of what happened in reality, the sentiments excited in Athens were, for Grote, perfectly justifiable. ${ }^{143}$ Grote re-created the scenes that should have normally taken place in Athens when the news had arrived. Joy for the exceedingly valuable victory; but also "horror and remorse at the fact that so many of the brave men who had helped to gain it had been left to perish unheeded". ${ }^{144}$ It is

${ }^{139}$ History, 6:315-16.

${ }^{140}$ History, 6:518. The Athenians, Aristotle confessed, "appear both in private and public to have behaved towards the past disasters in the most completely honourable and statesmanlike manner of any people in history" (Athenian Constitution, XL.2). Xenophon similarly praised the conduct of the Athenians (Hellenica, II.iv.43); and even Plato (Seventh Letter, 325B).

141 Ste Croix considers Grote's analysis of this event quite revealing and recommends it for study. See "The Character of the Athenian Empire", p. 33n.4.

142 The Athenian admirals, argued Goldsmith, "instead of being rewarded for so signal a victory, were made a barbarous instance of the power and ingratitude of their fellow-citizens" (Grecian History, vol. I, p. 323).

${ }^{143}$ History, 6:400. D.Kagan's recent account on the event is much depended on Grote. See The Fall of the Athenian Empire, Ithaca and London 1987, pp. 356, 363, 374.

${ }^{144}$ History, 6:400-1. 
preposterous, according to Grote, to expect that the Athenians would be elated at the news, and would absolve the generals of their desertion of the perishing warriors. The general sentiment became even more intense due to the simultaneous occurrence of the festival of Apaturia, which was the great annual occasion on which the members of each phratria (brotherhood) met to worship their protecting deities, and to vote on the enrolling of new members (i.e, sons born to members). ${ }^{145}$ Grote argued further that Xenophon misrepresented all these events in his desire to prove that the condemnation of the generals resulted from bribes and intrigues as well as from the violent emotion of the Athenian public. ${ }^{146}$ But Grote did not go as far as to justify the illegal proceedings that grew out of this reaction. He in fact condemned the whole proceeding as unjust:

Respecting the condemnation of these unfortunate men ... there can be only one opinion. It was an act of violent injustice and illegality, deeply dishonouring the men who passed it and the Athenian character generally. ${ }^{147}$

Hidden, however, in the heart of these external events Grote found the sentiments and expectations derived from Athenian patriotic and religious conscience. The case of the mutilation of Hermae had been invoked to blame the Athenians. ${ }^{148}$

${ }^{145}$ History, 6:413-14.

${ }^{146}$ A.Andrewes misunderstands Grote, when he asserts that, though Grote's long discussion "is still very much worth reading", his "uncritical acceptance of Xenophon", reduces its validity. Grote accepted the facts given by Xenophon with some alteration, but he rejected entirely his unfavourable judgments; see "The Arginousai Trial", Phoenix, 28(1974):112n.2.

${ }^{147}$ History, 6:425. See what Finley says on the occasion, "Athenian Demagogues", p. 20.

${ }^{148}$ History, 6:50n. See, e.g., Montagu, Reflections, pp. 94-5. Montagu called this event "an odd accident" that excited the "superstition and jealousy of the people" (p. 94). 
For Gillies it was an opportunity to blame the Athenians for their superstition, and Mitford, who was always critical of the Greek religion, regarded the mutilation of Hermae, and the sentiments that followed it, as "the worst evils of democratical frenzy". ${ }^{149}$ Grote showed that the damage inflicted upon the local Gods, apart from being a violent irreligious act, created deep uncertainty respecting the safety of the country and constitution. ${ }^{150}$ The public alarm was aggravated by two unprincipled politicians, Peisander and Charicles, who hereafter worked for the subversion of democracy. The conduct of the Athenians against Alcibiades, in Grote's view, was not blameable. He was justifiably considered as the chief conspirator, since he had already committed an offence against the sanctity of the mysteries. ${ }^{151}$ Alcibiades was on this occasion possibly a victim of a fabricated charge, dexterously designed by his enemies. It is to these men, and not to the Athenians collectively, that Alcibiades owed his condemnation. The historian, according to Grote, ought to take into account the Athenians' customs and religiosity; then it would be clear that they did not unreasonably believe that their democratic constitution was in danger. The offended Gods, i.e. the Gods habitually taken as protecting the state, required the punishment of those who were involved in the sacrilege; otherwise, they would have retracted their customary protection, and imposed upon the city severe and unpredictable miseries. Grote invited those who ascribed the deeds and agony of the Athenians to 'democratic folly' to compare the way the Christian, and, especially, the Catholic, Church provided for acts of sacrilege. The uniform tendency of Christian legislation, Grote argued,

\footnotetext{
${ }^{149}$ Gillies, History, vol. II, p. 358; Mitford, History., vol. II, pp. 242-3, 325.

${ }^{150}$ History, 6:33, 6:50n.

${ }^{151}$ History, 6:46; see Thucyd., VI.61 and Plutarch, Alcib., III.22-3.
} 
"down to a recent period, leaves no room for reproaching the Athenians with excessive cruelty in their penal visitation of offences against the religious sentiment. On the contrary, the Athenians are distinguished for comparative mildness and tolerance". ${ }^{152}$

Grote dealt with the Funeral Oration of Pericles, delivered in the second year of the Peloponnesian war, as a trustworthy and positive representation of the Athenian character. The same oration met Mitford's indifference and scepticism. ${ }^{153}$ What Grote praised more in the Athenian character, was the tolerance it showed of the diversity of tastes and pursuits. Athens facilitated the development and expression of individual talent. Pericles' speech, according to Grote, disproved those who alleged that the state in ancient Greece was constantly interfering with individual freedom, and that the individual citizen was sacrificed to the state's requirements. "This is preeminently true of Sparta:-it is also true in a great degree of the ideal societies depicted by Plato and Aristotle: but it is pointedly untrue of the Athenian democracy." ${ }^{154}$ In his Funeral Speech Pericles made it explicit that in a democratic system of government men were equal before the law in their private pursuit of eudaimonia, respecting and tolerating each other with earnestness and devotion. Socrates' career was considered by Grote as the fairest example of these principles. No modern government, Grote proceeded, "presents anything like the picture of generous tolerance towards social dissent and spontaneity of individual taste which we read in the speech

\footnotetext{
${ }^{152}$ History, 6:47-8, and 49-50n.

${ }^{153}$ Mitford, History, vol. II, p. 73.

${ }^{154}$ History, 5:71.
} 
of the Athenian statesman". 155

Athens attained the maximum of its vigour under Pericles. Democracy attained its maturity, and its regulations secured the free participation and expression of the individual. ${ }^{156}$ Pericles' greatest contribution, in Grote's view, was the encouragement he gave to "pacific and intellectual development-rhetoric, poetry, arts, philosophical research, and recreative variety". ${ }^{157}$ The Athenians did not adhere to a strict, Spartan-like, education. The average Athenian educated himself as to how to think, speak and act. Grote, in describing the retreat of the ten thousand Greeks, under the leadership of Xenophon, praised his treefold accomplishment (i.e. his distinction in thought, speech and act). Such a distinction was the aim of every Athenian citizen, and which the "Sophists as well as the democratical institutions ... helped and encouraged him to acquire". ${ }^{158}$

Grote also vindicated Athens from the charge of being responsible for the Peloponnesian war. Mitford and other conservative writers considered Athens as responsible for initiating the war. ${ }^{159}$ Grote examined in detail the conduct of Athens

${ }^{155}$ History, 5:73. The superiority of the Athenians over Spartans and other Greeks is repeatedly pointed out (e.g. Hist., 4:333, 9:458). Grote also argued that the Athenian judicial system was well designed as to exclude corruption (Hist., 4:442, and 464).

${ }^{156}$ See, J.de Romilly, La Grece antique a la decouverte de la liberte, Paris 1989, p. 72: freedom in ancient democracy meant principally participation in sovereignty, though not protection against it.

157 History, 5:98. Since 19th-century liberalism, remarks Ehrenberg, and "especially George Grote, discovered its ideal predecessor in ancient Athens, Pericles and his times have been regarded as the very fulfilment of human endeavour and cultural harmony" (From Solon to Socrates, p. 323).

${ }^{158}$ History, 7:253.

${ }^{159}$ Mitford blamed Pericles for initiating the war. See History, vol. II, p. 87. 
and Sparta in connection with existing alliances and current policies, and concluded that "Athens was in the right". ${ }^{160}$ Athens abstained from open hostilities and took the role of defender, whereas the Peloponnesian alliance was the aggressor. ${ }^{161}$ Grote investigated the motives of the Peloponnesians. It was not fear alone, but an obvious hatred of Athens that inspired their plans. ${ }^{162}$ Athens was already a large empire, but the records, argued Grote, did not refer to any effort on its part to make a new acquisition in the fourteen years following the conclusion of the Thirty years' truce. The Spartans and their allies, in effect, were possessed with an overwhelming jealousy towards Athens, and indulged in hopes of an easy victory.

\section{VII}

\section{Remarks on Sparta}

Grote's attack on Sparta is related only indirectly to his defence of Athenian politics and character. But as a reviewer of the History noticed, "who can love Athens and Sparta too?"163 To write the encomium on the Athenian constitution inescapably entailed a criticism of the Lacedaemonian form of government. Grote was critical of Spartan policy and constitutional arrangements. He put an end to the fashionable vindication of Sparta, which was assumed to be the finest polity in ancient Greece.

${ }^{160}$ History, 5:19.

161 Thirlwall argued with his habitual moderation that Sparta "was desirous of humbling Athens, but apparently without any design of stepping into her place. She was the aggressor, but under a conviction of the necessity of the measure" (History of Greece, vol. IV, p. 169).

${ }^{162}$ Similarly, Meiggs, The Athenian Empire, p. 200.

163 N.L.Fronthingham, "Grote's History of Greece", Christian Examiner, 62(1857):59. 
Grote opposed not only his contemporaries, and earlier writers of the eighteenth century, but also the fathers of Greek philosophy, Plato and Aristotle, as well as Xenophon, Lysias and Isocrates. In Spartan structure and practice Grote saw the rigid antagonist to Athenian democracy. Absorbed solely in the cultivation of military art, hostile, or at best indifferent to mental improvement, the Spartans were destitute of those qualities that might have appealed to his sympathy.

The tendency of the Spartans to exclude other Greeks from their religious and gymnastic festivals, at a period when the greater states in Greece promoted reciprocal admission to their local festivals, did not escape Grote's criticism. These religious festivals and agones doubtlessly, Grote remarked, promoted Greek fraternity. A 'Panhellenic' audience in local festivals, necessarily encouraged the "sentiment of Hellenic unity". ${ }^{164}$ Citizens of other states experienced a feeling that counterbalanced their political disunion. ${ }^{165}$ Grote emphasized the positive effects these festivals should have had upon the Greek mind. Sparta, however, had chosen to avoid publicity, an early sign of the secrecy that characterized its policy. Consequently, Sparta hindered the propagation of a common Greek consciousness, and fostered the notion of natural inequality.

Grote criticized more severely the policy of imperial Sparta. Having superseded Athens it imposed inhuman severities upon its subjects. Mitford attempted to show

${ }^{164}$ History, 3:294. See Thucyd., II.39.

${ }^{165}$ Grote ascribed the same effect to Greek art, which aided the development of a common consciousness. This common feeling is what he called the "extra-political Hellenism" in earlier times; that is to say, national, without political union. See History, 3:321-3. 
that an external regulator was required to organize a common policy. ${ }^{166} \mathrm{He}$ also asserted that the internal dissentions induced the subordinate states "not only to admit readily, but often to desire the controuling interference of the imperial people". ${ }^{167}$ But if Sparta's political presence, as the ultimate regulator of political issues, was particularly indispensable, then, why should Athens' interference in local policies be taken as obnoxious and cruel? Mitford called these 'regulators' "superintending officers", whereas Grote argued that they were harsh dictators. Spartan commanders (harmostes) who were appointed by the imperial state often treated wrongfully their subjects. Those suffered under their administration could not seek redress at the courts of Sparta with many chances of obtaining it. ${ }^{168}$ This is the liberty and autonomy Sparta promised in 432, and Brasidas continued to promise throughout the war. When the war ended Grote argued that Sparta revealed its real face. Sparta's empire, compared to the Athenian, was more oppressive. ${ }^{169}$ Most importantly Sparta, after the battle of Aegospotamoi, could have proceeded to the organization of a stable confederacy throughout Greece - a union founded on common interests. Sparta refused to sacrifice its own interests and ambition at the most suitable time in the history of

${ }^{166}$ See BL Add. MS 29,520 (1815-1851), fo. 189: Grote observed that Mitford made but a short reference to the conduct of the Lacedaemonians when they controlled the empire of Greece: "I do not observe that M.[itford] gives any statement of the oppressive conduct of the harmosts and decadarchies".

${ }^{167}$ Mitford, History, vol. II, pp. 418-9.

${ }^{168}$ History, 7:357-8.

${ }^{169}$ As Thirlwall earlier argued, Spartan imperial rule proved that "the dominion of an oligarchy might be still more oppressive to its foreign dependents than that of a democracy" (History, London 1838, vol. V, p. 155). 
Greece for the realization of stability and internal concord. ${ }^{170}$ Instead of promoting general peace and local autonomy, Sparta proceeded inexcusably to surrender the Asiatic Greeks to Persia, thus securing for itself a 'shameful' treaty with that country, and many financial advantages. ${ }^{171}$ Sparta submitted to Persia as a means of strengthening its influence. The Asiatic Greeks were the first to realize practically the importance of an independent Athenian maritime power and influence. ${ }^{172}$

According to Grote, Sparta committed many anti-hellenic deeds. "One of the most odious acts of high-handed Spartan despotism"173 was to cut into parts (small villages), the ancient city of Mantineia. In the same spirit Sparta crushed the Olynthian confederacy, placing the Greek cities under the control of Macedonia (379 B.C.). The Olynthian union could have been the guardian of the Greek cities in the Chalkidic peninsula against the ambitious plans either of Macedonia or Thrace. The union was liberal and promising; never again, after its dissolution by Spartan arms, did there occur the opportunity of organizing a firm alliance to protect the general interests of the Greek nation. Grote related the ascendancy of Philip a few years later, who, in his opinion, produced the gradual destruction of Greek life, to this early mischief done by Sparta to Greece. The dissolution of the growing Olynthian federation, and the reconstitution of maritime Macedonia were both "signal misfortunes to the Grecian

${ }^{170}$ History, 7:369.

${ }^{171}$ See Grote's remarks on the peace of Antalkidas, History, 7:546-7, and 8:5-6. Isocrates similarly, criticized the peace of Antalkidas throughout the Panegyricus; see, e.g., $85,115-116$.

${ }^{172}$ History, 7:373; 8:26. See W.G.Forrest, A History of Sparta 950-192 B.C., London 1968, pp. 126-7.

${ }^{173}$ History, 8:36. 
world. Never were the arms of Sparta more mischievously or more unwarrantably employed". ${ }^{174}$

Grote was also critical of Sparta's internal policy. Although historians had praised the political and educational system established by Lycurgus, ${ }^{175}$ Grote argued that Lycurgean education had few positive effects. A Spartan youth might have acquired peculiarly high qualifications for distinguishing himself in war, but it rendered him harsh and incapable of surpassing the narrow limits of his individuality. ${ }^{176}$ Grote was more critical of the hard treatment of the Helots as revealing the "inhuman character of the Lacedaemonian government". ${ }^{177}$ The Spartans established the Crypteia, groups of armed young citizens, and sent them throughout Laconia to assassinate any Helot distinguished for his bravery and character. ${ }^{178}$ Amidst such secret proceedings they caused the murder of 2000 Helots

\section{${ }^{174}$ History, 8:64-5.}

${ }^{175}$ See Mitford, History, vol. I, p. 198, and pp. 220-21, for Lycurgus' encomium; and Montagu, Reflections, pp. 72-3. Regarding Lycurgus' reforms Stanyan argued that it is surprising "that a Pagan, who was indeed too indulgent to adultery, theft, and, in some cases, to murder itself, should in the rest approach so near to Christian morality, as sometimes to overtake it" (Grecian History, vol. I, p. 85). In the same spirit see Charles Rollin, The Ancient History, London 1813, vol. II, p. 381; Goldsmith, Grecian History, vol. I, p. 15; Drummond, A Review, p. 53.

${ }^{176}$ Young maintained that Lycurgus "having treated men as wild beasts, he had made them so; his plan was to chain, and not to humanize" (History of Athens, p. 148).

${ }^{177}$ History, 2:294-5. Grote's explanation of the rise of slavery in ancient Greece can be found in University of London Library, MSS 429/3 (1817), fo. 132.

${ }^{178}$ To Goldsmith the Spartans' cruel treatment of their slaves appeared "truly amazing", in so far as the Spartans were renowned for their virtuous character (Grecian History, vol. I, p. 36). 
in the eighth year of the Peloponnesian war. ${ }^{179}$ Criticizing their murderous secrecy on this occasion Grote remarked that their stratagem of entrapping the 2000 Helots was "so perfidious in the contrivance, so murderous in the purpose, and so complete in the execution, [that] stands without parallel in Grecian history - we might almost say without a parallel in any history". ${ }^{180}$ The Lycurgean constitution, with its secrecy and austerity, and its demand for single-minded obedience, appeared to Grote, as we shall see, embodied in Plato's Republic.

${ }^{179}$ History, 2:295, 5:283-5. For this event see, Thucyd., IV.80, 3-4.

${ }^{180}$ History, 5:284-5. Bulwer similarly described with horror this event, Athens, vol. I, p. 227. 


\section{Chapter 4}

\section{THE DEBATE OVER GROTE'S HISTORY OF GREECE}

Much has been said, in the previous chapter, to make clear that Grote was distinguished primarily as the historian of Athens. Grote's defence of ancient democracy was doubtlessly connected to the development of nineteenth century liberalism, and his avowed utilitarian philosophy. Ancient democracies, Grote believed, attempted "to ensure the beneficent direction of the powers of government, as well as to break down the monopoly and counteract the sinister interests of the wealthy few". Ancient democracies were "eminently valuable from the development of individual talents, which they occasioned". ${ }^{1}$ It was because of its democratic constitutional framework that Athens attained such unrivalled preeminence, and became a source of inspiration for future generations.

Grote's defence of Athens, the first systematic defence ever attempted, was admittedly also a defence of liberal principles. But Grote's work was not a "political pamphlet in twelve volumes"; ${ }^{2}$ he did not give up historical precision to serve narrow political objectives. ${ }^{3} \mathrm{He}$ was a philosophical empiricist, who, as Momigliano argued,

\footnotetext{
${ }^{1}$ BL Add. MS 29,520 (1815-1821), fo. 204.
}

2 J.P.Mahaffy, "A Critical Introduction", in V.Duruy History of Greece, London 1892, vol. I, p. 9. E.Meyer, Geschichte des Altertums, vol. III (1915), p. 239 (quoted in K.Popper, The Open Society and its Enemies, London 1952, vol. I, p. 297n.15), called Grote "'an English radical leader', and his work 'not a history, but an apology for Athens', i.e. an apologia for democracy."

${ }^{3}$ See A.P.Stanley, "History of Greece", Quarterly Review, 86(1850):386; and J.N.Claster, Athenian Democracy: Triumph or Travesty? New York 1978, p. 68. 
"possessed the all-redeeming virtue of the liberal mind". ${ }^{4} \mathrm{He}$ respected evidence, and believed that an historian of ancient Greece should be ready to employ his critical power in order to discriminate between a matter of fact - a purely historical event and a personal judgement based on scraps of information that he possessed. Grote emphasized that ancient historians and philosophers, like Thucydides, Xenophon and Plato, were not prepared to disallow their political prejudices in favour of an 'objective' record of events. As J.S.Mill observed, Grote understood that a "history of Greece, to be of any value, must be ... a running commentary on the evidence". ${ }^{5}$ The debate that followed the History shows that Grote's defence of Athenian policy and institutions was influential. In examining the reception of his work it will be best shown that Grote marked the beginning of a new period in ancient historical interpretation.

\section{I}

\section{Defects Existing in Earlier 'Histories'}

One of the characteristics that marked the beginning of the post-Grotean period in the field of Hellenic studies was the clear apprehension of the defects of earlier historical works. Gillies' History came to be thought of as a reflection of the events of the French Revolution and of his profound distrust of democratic government. Mitford simply represented strong Tory conviction.

${ }^{4}$ Grote, A.Momigliano continued, "was determined to understand and respect evidence from whatever part it came; he recognized freedom of speech, tolerance, and compromise as the condition of civilization; he respected sentiment, but admired reason" (George Grote and the Study of Greek History, London 1952, p. 20).

5 Mill, "Grote's History of Greece" [II], C.W., vol. XI, p. 330. Similarly see G.W.Greene, "Reminiscences of George Grote", Atlantic Monthly, 44(1879):772. 
George Henry Lewes not only contrasted Grote's History with English writers, but also with the "somewhat narrow and pedantic Germans", whose works, though full of imagination, lacked trustworthiness. ${ }^{6}$ Leonard Whibley, in the same spirit, contrasted Grote with the "old school of historians represented by Bockh and K.F.Hermann, and caricatured by Mitford", who accepted without reserve the blame cast on democratic Athens by ancient writers. ${ }^{7}$ The Germans, according to Henry Milman, though long occupied with the writing of books and treatises, valuable in themselves and related to every branch of Greek antiquities, had not produced a single commanding work. In 1846 German literature lacked a full and complete History of Greece. ${ }^{8}$ George Cornewall Lewis, participating in this general tendency of criticising German scholarship - a tendency originated from the results of Grote's labour - argued that the general characteristic of the most eminent German historians of antiquity is "that they are sceptical as to received facts, but credulous as to their own hypotheses, or the favoured hypotheses of some of their own school". ${ }^{9}$

The anonymous reviewer in the Eclectic Review did not hesitate to pronounce Grote's defence of the Athenian democracy not merely successful against Mitford's libel but also against Xenophon, Plato, and Socrates. ${ }^{10}$ Margaret Foster called Mitford's History a "truly monarchical history of Greece", expressing simultaneously

${ }^{6}$ G.H.Lewes, "Grote's History of Greece", Westminster Review, 46(1847):385.

7 L.Whibley, Political Parties in Athens during the Peloponnesian War, Cambridge 1889, p.2.

${ }^{8}$ H.H.Milman, "Grote's History of Greece", Quarterly Review, 78(1846):113.

${ }^{9}$ G.C.Lewis, "Grote's History of Greece" (I), Edinburgh Review, 91(1849):121.

${ }^{10}$ Anon. (1), "Grote's History of Greece", Eclectic Review, 22(1847):290. 
her delight for the general approbation that Grote's philosophical history received. ${ }^{11}$ The reviewer in Tait's Edinburgh Magazine spoke about Mitford's involvement in the field of Greek research solely as a means of "eternizing a wretched Pitt politics"; every great act that appeared democratic in his eyes, was offensive "to that selfish, sceptical, utterly negative, and all-shivering aristocraticism which they called the conservatism, (save the mark!) of the idol of the then statesmen of England!"12 John Anster criticized those writers who had made Greek history the vehicle of their own beliefs, the most prominent among them, Mitford. Yet, greater harm had been done, in Anster's view, by the various annotators of Aristophanes..$^{13}$ John Stuart Mill regarded the comparison between Grote's History, and earlier works inevitable. Grote's work, Mill believed, surpassed even the best previous achievements (e.g., Thirlwall's History). In his article in the Spectator Mill declared that it was hardly imaginable that such a specimen of narrative could be surpassed by any English historian. Its virtues were so striking, the deep understanding of events, and the talent imparting them vividly to the readers so imposing, that it would not be easy to find a superior work among those published in any country. ${ }^{14}$

${ }^{11}$ M.Foster, "Grote's History of Greece", London Quarterly Review, 7(1856):51.

12 Anon. (2), "Grote's History of Greece", Tait's Edinburgh Magazine, 13(1846):375. A.D.Lindsay regarded Grote's defence of Athenian democracy as a "natural reaction against the foolish carpings of anti-democratic historians like Mitford" ("Introduction" to Grote's History, Everyman's ed., London 1906, p. vii).

13 J.Anster, "Grote's History of Greece" (I), Dublin University Magazine, 35(1850):754.

${ }^{14}$ J.S.Mill, "Grote's History of Greece - VOLUMES V and VI", The Spectator, (3 March 1849), in C.W., vol. XXV (1986), p. 1122. 
It is not surprising that Grote's History was favourably received in America.

History, as written in Europe, James Champlin argued,

and especially in England ... is little else than a high-sounding, manyvoiced chorus, chanting the praises of monarchical institutions. The choir historical, like that of the ancient tragedy, has generally been composed of a select class of venerable men surrounding the throne, or sufficiently near it to secure the steadiness of their political sympathies. ${ }^{15}$

The New York Quarterly reviewer attacked Mitford for applying the political passions of the day to the study of ancient history. Mitford's "ignorance of the true spirit of antiquity", according to the same reviewer, "and his atrocious style, got possession of the ground, and held it, and diffused more error and prejudice with his four quartos than quartos ever diffused before". ${ }^{16}$ Cornelius Felton, the distinguished American classicist, pointed out that the influence of party spirit, well-discerned in English historians' works, had significantly diminished their authority. Standing at either the Tory or the Radical extreme, Felton continued, English historians had looked upon the events of ancient Greek history in light of their own political persuasions. ${ }^{17}$ Mitford, according to Felton, wrote under "the panic then created in Tory breasts by the French Revolution". ${ }^{18}$

15 J.T.Champlin, "Grote's Greece", Christian Review, 16(1851):483-4.

${ }^{16}$ Anon. (3), "Grote's Greece", New York Quarterly, 3(1854):110. The anonymous reviewer who stated that he met Grote on the occasion of his visit to Italy (Dec. 1841, see Personal Life, pp. 146-151), mentioned that Niebuhr was aware that Grote was composing a history of Greece, and that "he expected great things" from him (p. 106).

${ }^{17}$ C.C.Felton, "Grote's History of Greece" (Review of vols I-VI of the Boston edn, Little and Brown), Christian Examiner and Religious Miscellany, 48(1850):294-5.

${ }^{18}$ Ibid., p. 296. 
II

\section{Different Views Concerning the Application of Modern Concepts to the Explanation of Ancient Politics}

Momigliano argued in 1952 that "Much of the recent work on Greek early traditions is pre-Grotean in character" ${ }^{19}$ He believed that historical evidence was distorted mainly because the generation of historians in the 1940s found it difficult to assess the value of evidence. Such a low estimate of historical evidence, Momigliano believed, characterized also the period before Grote . Headlam detected earlier a decline in the method of historical investigation. According to Headlam, the major cause of this decline was the growing tendency to apply modern political experience to the interpretation of Greek political events. This method, "which was used with such admirable results by Grote" was unsafe and unproductive, since those who have employed it lacked the practical experience, or the quick intuition of Grote in dealing with political matters. ${ }^{20}$ But Grote's immediate reviewers were at variance as to the extent Grote applied modern experience and concepts to his explanation of ancient politics.

First, most of Grote's reviewers referred to his political views, which, in their opinion, shaped partly his historical judgements. ${ }^{21}$ Freeman for instance, commented on Grote's avowed "partisanship", and his love of paradox. ${ }^{22}$ Freeman went on to

${ }^{19}$ Momigliano, George Grote, pp. 17-8, emphasis added.

${ }^{20}$ J.W.Headlam, Election by lot at Athens, Cambridge 1891, p. xiii.

${ }^{21}$ Cf. Lindsay, "Introduction" to Grote's History, Everyman's ed., London 1906, p. vii.

${ }^{22}$ E.A.Freeman, "Grote's History of Greece", North British Review, 25(1856):143. Leopold von Ranke again spoke of a "preconceived opinion, which has sometimes a 
acknowledge, however, that the historian's work had a calm and dignified tone. "Mr Grote's political views colour his judgments, but they in no way colour his statements. ${ }^{.23}$ William Goodwin, in reviewing the American edition, praised the "true liberal spirit" that pervaded the whole work and appeared for the first time in an English historical composition. ${ }^{24}$ After criticizing those who had converted the history of Greece into a field for modern party political disputes, Smith pointed out that though someone could expect the statements of the "too liberal politician" to be accordingly coloured, he ultimately found only a certain tone in some of his political observations. $^{25}$

There was disagreement as to the use of contemporary political ideas in Grote's History. In Emerson's view, Grote's excellence consisted primarily in that he did not view ancient Greece through the spectacles of modern society. The applied criteria for the distinction between just and unjust, fair and unfair, excellent and defective, etc., are those the ancients themselves endorsed. In this respect Grote, according to Emerson, "makes himself a contemporary of the people whose history he records". ${ }^{26}$ J.S.Mill similarly argued that Grote's narrative is "a picture of the

detrimental effect on the work of that excellent historian" (Universal History, London 1884, p. 269n). See also, W.Mure, A Critical History of the Language and Literature of Antient Greece, London 1853, vol. IV, p. 522.

${ }^{23}$ Ibid.

${ }^{24}$ W.W.Goodwin, "Grote's Greece", North American Review, 78(1854):151.

${ }^{25}$ W.H.Smith, "Grote's History of Greece, Blackwood's Edinburgh Magazine, 62(1847):144-5.

${ }^{26}$ G.H.Emerson, "Grote's History of Greece", The Universalist Quarterly and General Review, 14(1857):62. "Surely, this Mr.Grote, must be a Greek! ... [I]t requires a conscious effort of reflection to be assured, that our author is an Englishman of the nineteenth century" (pp. 55-6). 
Greek mind", and Grote himself becomes 'a Greek'. No writer, in Mill's view, had made the reader enter into the religious feelings of the Greeks as Grote did. ${ }^{27}$ The same opinion was shared by William Smith, whose review as we know from Harriet Grote, particularly pleased our historian. ${ }^{28}$ Smith contrasted Grote's History with previous writings - with the exception of Thirlwall's - which placed the Greeks under the severe judgements of modern standards of religion, morals, and politics. Grote, on the contrary, divested himself of modern ideas, and "transports himself into Hellenic society", endeavouring "to view the events of Grecian history with the eyes of a contemporary, and to realise to his own mind the various phenomena of Grecian thought and feeling". ${ }^{29}$ Lewis Packard believed that though an Englishman, whose friends were among the leading Liberals in politics and ethics, and whose practical training could be discerned in his treatment of myths or the Athenian constitution, Grote, "Englishman as he was, he made himself, by study and habit, at home in the Greek world, and able to look upon events in its life as if he had been an Athenian" ${ }^{30}$ Schomann, the eminent German historian, unlike other critics, pointed out that Grote's ability to empathise with ancient Greece could possibly have led him to a partial position. Grote could live with the ancient Greeks; he could feel as a

${ }^{27}$ C.W., vol. XI, p. 332; similarly anon. (4), "Grote's History of Greece", Eclectic Review, 20(1846):280.

${ }^{28}$ H.Grote, Personal Life, p. 231.

29 W.Smith, "Grote's History of Greece", Quarterly Review, 99(1856):62. W.H.Smith argued that Grote's distinguishing merit is the fidelity to the spirit of the epoch upon which he is engaged. See "Grote's History of Greece", p. 143; similarly Peter Anton, Masters in History. Gibbon, Grote, Macaulay, Motley, Edinburgh 1880, p. 90.

${ }^{30}$ L.R.Packard, "Grote and Curtius", New Englander, 34(1875):127-8. 
contemporary of the men whose life he narrated; he could penetrate their innate thoughts and sentiments, hopes and intentions, fears and passions. Thus, he could easily lose his impartiality by identifying himself with the interest of a particular actor. Nevertheless, Schomann concluded that Grote managed to remain an impartial observer, whose "liveliest sympathy with the actors does not impair the independence and impartiality of his judgment". ${ }^{31}$

Other scholars believed that Grote's interpretation originated from his tendency to see the history of Greece through the eyes of a nineteenth-century man. Champlin, for instance, ascribed the greatness of Grote's work, apart from the liveliness of his narrative, to the "habit of viewing ancient in the light of modern history". ${ }^{32}$ It is only in this way, Champlin believed, i.e., by making Greek political life relevant to contemporary issues, that Grote succeeded in making the history of Greece intelligible and interesting. Champlin was anticipated by the Eclectic reviewer, who had been inclined to view the analogies drawn between the ancient world and modern constitutional politics, "as pre-requisites to give us insight into the working of the old republics". ${ }^{33}$

${ }^{31}$ G.F.Schomann, Athenian Constitutional History, as Represented in Grote's 'History of Greece', translated from the German (Die Verfassungsgeschichte Athen's nach G.Grote's 'History of Greece', Leipzig, Weidmann 1854) by Bernard Bosanquet, Oxford and London 1876, p. 1. Schomann stated that Grote's acquaintance with the ancient sources, the Greek spirit and intellect, is so deep and exhaustive that "he can live, as it were, with the ancient Hellenes; and he thinks and feels as a contemporary of the men whose acts and destiny he narrates" (p. 1).

${ }^{32}$ Champlin, "Grote's Greece", p. 503.

${ }^{33}$ Anon. (1), "Grote's History of Greece", p. 290. 
III

The Athenian Democracy, Character, Constitution, and Empire

\section{Reestimated Under Grote's Impulse}

(i) The Athenian Democracy Reexamined

It is one of the most fruitful aspects of Grote's contribution that his work prompted the re-examination and re-assessment of Athenian politics and character. Under Grote's influence Athens and its constitution started to be seen in a more favourable light. ${ }^{34}$ Grote put an end to the harsh ideological divisions regarding discussions of Athenian life and policy, which dominated earlier writings.

The interaction between Athenian culture and civil government was acknowledged. ${ }^{35}$ Philip Smith argued emphatically that what "gives Athens her unique position in human history, the intellectual supremacy ... was the fruit of her political freedom". ${ }^{36}$ It was further acknowledged that the success of Athenian democracy depended on its allowing its citizens without discrimination to participate in government, including the performance of executive functions. The Athenians, argued Freeman "invested with executive functions constituted one of the best governments which the world ever saw". ${ }^{37}$

${ }^{34}$ See J.S.Blackie, Horae Hellenicae, London 1874, p. 197.

${ }^{35}$ See, e.g., Freeman, "Grote's History of Greece", p. 142. Ranke claimed that Athenian greatness was founded upon the influence of democracy. See Universal History, p. 229.

${ }^{36}$ P.Smith, History of the Ancient World, London 1873, vol. I, p. 467.

${ }^{37}$ Freeman, "Grote's History of Greece", p. 158. E.Curtius, whose History was published in 1857-67 at Gottingen, similarly maintained that "the participation of all in the transactions of state offered a pledge that no low and petty motives, such as are not unlikely to decide the course of oligarchic bodies, dictated the resolutions of the political community" (History of Greece, New York 1892, vol. II, p. 487) 
J.S.Mill in his turn pointed out that Athenian democracy enjoyed eunomia, "the unimpeded authority of law, and freedom from factious violence". ${ }^{38}$ Hence, safeguarding the integrity of life and property, the Athenian constitution afforded the fitting climate, and mental disposition, for the cultivation of the intellect and imagination. ${ }^{39}$ The Athenian constitution was to be praised for affording the individual his due space of action, and freedom to improve his manners and personality. Instead of arguing over minor points, it would be better, Mill argued, "to consider whether we have ... advanced as much beyond the best Grecian model, as might with reason have been expected after more than twenty centuries". ${ }^{40}$

Grote maintained that Athenian democracy permitted the free expression of individual needs and talents, and thus created a fitting climate for cultural distinction. Smith supported this point of view. The history of Athens, in his judgement, was living proof that ancient societies did not collectively sacrifice the individual to the state, as it was regularly asserted. Athens practically tolerated individual tastes and pursuits. Pericles's 'Funeral Speech' was an imperishable testimony, recorded by an aristocrat, ${ }^{41}$ of the Athenians' tolerance. ${ }^{42}$

${ }^{38}$ Mill, "Grote's History of Greece", C.W., vol. XI, p. 316.

${ }^{39}$ See Mill, C.W., vol. XI, p. 316; similarly Victor Duruy, History of Greece, London 1892, vol. II, 2:633.

${ }^{40}$ Mill, C.W., vol.XI, p. 313.

${ }^{41}$ See F.B.Jevons' remarks on Pericles position and politics, and his defence of Athens in The Development of the Athenian Democracy, Durham 1886, p. 20.

${ }^{42}$ W.Smith, "Grote's History of Greece", pp. 67-8. Cf. W.W.Fowler, The CityState of the Greeks and Romans, London 1895, p. 150; see also, pp. 157, 175, 177; and Curtius, History of Greece, New York 1892, vol. II, p. 487. 


\section{(ii) The Athenian Character Reconsidered}

In the same way as scholars re-examined Athenian democracy under a new impulse, and viewed it afresh, they came to reconsider the nature of Athenian character. Prior to Grote, as has been shown, the Athenians were represented as a fickle, unsteady and ungrateful mob, warlike and hostile to the rich. After Grote's History was published the belief developed that the Athenians were a noble people who displayed many examples of "moderation and good faith", in their conduct. ${ }^{43}$ Rather than unsteadiness and inconstancy, their policy was marked by a sometimes unexplained obstinacy, as their confidence in Nikias during the fatal expedition to Sicily proved. ${ }^{44}$ Mill ascribed to the Athenians a remarkable constancy in their attachments. In changing their opinions they were not, as had been stated, fickle, but mobile. ${ }^{45}$ They firmly respected their constitutional rules. If we are to ascribe to them any peculiar characteristic, Mill continued, this should be their "easy and good-natured a confidence", shown by their toleration of individuals evidently inclined to subvert their constitution, as Peisander and Antiphon. ${ }^{46}$ Bain, likewise, emphasized the Athenians' "extraordinary respect for constitutional forms". ${ }^{47}$ These "constitutional

${ }^{43}$ Freeman, "Grote's History of Greece", p. 159; Duruy, History of Greece, vol. III, 2:407.

${ }^{44}$ Freeman, Ibid., pp. 160-1. G.W.Cox, criticized Nikias of "caring more for the policy of his party than for the wider interests of his country" (History of Greece, London 1874, vol. II, pp. 187-8).

${ }^{45}$ Mill, C.W., vol. XI, p. 317.

${ }^{46}$ Mill, C.W., vol. XI, p. 327; see also, The Spectator (16 March 1850), C.W., vol. XXV (1986), p. 1161: Nowhere in antiquity "was respect for law so deep-rooted a principle as at Athens".

${ }^{47}$ A.Bain, Minor Works, London 1873, p. [90]. 
forms' in Curtius's view, were pervaded by a moral purpose, and demanded from the individual "fidelity, justice, love of truth, and readiness for self-sacrifice ".48 According to Lewis, justice and only justice had been rendered to the Athenian character by Grote. It was a character distinctly marked by respect for political morality, which constrained the minority to comply with the public will. ${ }^{49}$ Grote, according to another critic, had successfully proved that errors and crimes were not inherent in democratic government (as Plutarch and Mitford believed), but "are the offspring of human passion, prejudice, and folly" - common elements in both monarchical and democratic governments. ${ }^{50}$ For the London Quarterly reviewer the Athenians were a perfect exemplification of the true Greek character. Outwardly they seemed incapable of anything else but dance and enjoyment, yet they were deeply loyal, and capable of great intellectual achievements. ${ }^{51}$ Fowler expressed his admiration for the Athenian character, and underlined the "sanity, the reasonableness, of the Athenians and their leading men". 52

${ }^{48}$ Curtius, History of Greece, vol. I, p. 428.

49 G.C.Lewis, "Grote's History of Greece" (II), British Quarterly Review, 13(1851):317-18.

50 W.Smith, "Grote's History of Greece", p. 98. Similarly see T.R.Glover, Democracy in the Ancient World, Cambridge 1927, p. 72; A.W.Gomme, More Essays in Greek History and Literature, Oxford 1962, p. 192; M.I.Finley, "Athenian Demagogues", Past and Present, 21(1962):20.

51 See anon. (5), "Greek History", London Quarterly Review, 28(1867):26); R.D.Hampden, The Fathers of Greek Philosophy, Edinburgh 1862, p. 213.

${ }^{52}$ See Fowler, The City-State of the Greeks and Romans, p. 158. 
(iii) On the Courts and Constitution of Athens

Two major aspects of the working of the Athenian constitution were much discussed. First, there was the eligibility of all citizens for the various offices, and the consequent curtailment of the formal power of the Areopagus. Secondly, the systematic securities established to protect the individual from interference into his private domain, e.g., by legal means, as well as for the self-protection of the constitution against external or internal disorders. It was also accepted that Grote's analysis of the three major constitutional periods in Athenian history (i.e. the Solonian, Cleisthenian, and Periclean) was accurate and penetrating. Ephialtes and Pericles, with their policies, gave a democratic form to their constitution. ${ }^{53}$ Cleisthenes' policy effected a considerable change in Athenian constitutional character. The most important of his proceedings was the reduction of the real power of the council of Areopagus, which had gathered the aristocratic elements of the city, and, as Duruy argued, was "the conservative element" in the Athenian constitution, hostile to innovations. ${ }^{54}$ Starting with Cleisthenes, and maturing with Pericles, the Athenian constitution became a democracy. The Athenian constitution, in the words of Mill, "was so far a democracy, that it was government by a multitude, composed in majority of poor persons ...; it was a government of boundless publicity and freedom of speech". 55

53 See, e.g., Freeman, "Grote's History of Greece", p. 155; G.C.Lewis,"Grote's History of Grrece" (I) p. 138; Anon. (5), "Greek History", pp. 24-5; Anster, "Grote's Greece" (II), Dublin University Magazine, 45(1855):485.

${ }^{54}$ Duruy, History of Greece, vol. II, 2:545-6. See further, Cox, History of Greece, vol. I, p. 229.

55 J.S.Mill, C.W., vol. XI, p. 324. 
One of the scholars' main concerns (which was also Grote's cardinal object) was to lay stress on the securities and formalities with which the Athenian constitution was invested; so implying that a citizen's life in Athens, either rich or poor, of aristocratic or ordinary origin, was not exposed to violence and interference. The officials in those posts that demanded special abilities and character were elected by vote, and not by lot. But even those who were expected to be elected as magistrates by lot, could have been excluded after failing in the dokimasia, or examination before admission. ${ }^{56}$ Those whose term of office had ended had to pass through the euthyne, or examination after retirement. They should have been able to prove that their conduct had not been in conflict with the laws of the state. The council of Five Hundred, working openly, could never become a body able to undermine the constitution for the councillors' benefit, as was the case with the Areopagus and the senate of Rome. ${ }^{57}$ There were also pressures to compel politicians to act responsibly. Personal responsibility, according to Holm, "permeates the whole polity of Athens". ${ }^{58}$ The Athenian was normally hesitant in proposing a new law, or a change in an existing law, since he would do so only at his personal risk. He made himself liable to the Graphe Paranomon, or indictment for informality or illegality, and after conviction he could incur a severe penalty. ${ }^{59}$

${ }^{56}$ Fowler, The City-State of the Greeks and Romans, p. 170; Freeman, "Grote's History of Greece", p. 156. On the dokimasia, see C.Hignett, A History of the Athenian Constitution, Oxford 1970, pp. 205-7.

${ }^{57}$ Fowler, Ibid., p. 170.

${ }^{58}$ Adolf Holm, History of Greece, London and New York 1902, vol. II, p. 209, n.15.

${ }^{59}$ Duruy, History of Greece, vol. II, 2:655. See Hignett's remarks on Grote's discussion on the graphe paranomon, History of the Athenian Constitution, p. 211. On 
Grote argued that crimes of outrage often committed by the rich under an oligarchy would not be tolerated by a court of Athens under the democracy ${ }^{60} \mathrm{He}$ was mistaken, however, about the institution of the dikasteries, in seeing there the separation of the judicial power from the executive..$^{61}$ Further, his parallel between the jury-trials in Europe, and the Athenian trials was disputable. ${ }^{62} \mathrm{He}$ had successfully shown however, as Mahaffy rightly pointed out, that the professional advocates of the litigants answered a historical need in the context of Athenian law proceedings. They, of course, did not cause any sort of moral degradation. This was an idea passed to later generations by comedians and philosophic aristocrats. ${ }^{63}$ As regards the severe criticisms of Plato, Isocrates and Aristotle, Fowler rightly argued that "It is not scientific to judge of the working of Athenian institutions in the fifth century B.C. by the opinions of men who knew them only as worked by a degenerate population in the fourth". .4

Where, then, lies Grote's misjudgement concerning the impartiality of the Athenian courts of justice? The fundamental defect of the Athenian system of justice

the institution itself, see Gomme, More Essays, p. 191; Finley, "Athenian Demagogues", p. 21.

${ }^{60}$ See BL Add. MS 29,520 (1815-1821), fo. 208. P.Smith noted that Grote "has triumphantly refuted the calumny which depicts the dicasts as delighting, with a sort of wanton levity, in hunting down an unhappy defendant" (History of the Ancient World, London 1873, vol. I, p. 460).

${ }^{61}$ See Bain, Minor Works, p. [87].

${ }^{62}$ W.Smith was, however, in agreement with Grote, "Grote's History of Greece", p. 89.

${ }^{63}$ J.P.Mahaffy, A History of Greek Literature, London 1910, vol. II, Part I, p. 82.

${ }^{64}$ Fowler, The City-State of the Greeks and Romans, pp. 153-4. 
consisted in its non-separation from political connections; a defect notoriously revealed in the case of the Arginusae trial. Bonner, in discussing the case, argued that the notorious result of this trial does not by any means show the fickleness and unreflectiveness of the Athenian mob; the trouble, in Bonner's view, "lay rather in using a political body as a tribunal". ${ }^{65}$ Bonner's point had been long ago made by the London Quarterly reviewer. According to this scholar, the Athenian jury was an uncontrolled political body. The man, he argued, "who one day was an ardent and vehement member of the public assembly, the next day might be chosen to sit in judgement on the orator whom he had hooted from the Pnyx". ${ }^{66}$ The people, previously exerting their political functions, could not but convey their passions and controversies into their judicial proceedings. This abrupt turn, from questions of policy to legal trials, normally tended to minimize the effect of constitutional safeguards.

\section{(iv) On the Athenian Empire}

Many scholars joined Grote in his favourable view of the Athenian empire. It became clearer that the Athenian empire was not something planned beforehand; and that it was not, given the circumstances, oppressive and tyrannical. Further, it was argued that in spite of the character of sovereignty over tribute-subjects, the Athenian empire promoted drastically, and on a large scale, the interests of the Greek nation. p. 250 .

${ }^{65}$ R.J.Bonner, Lawyers and Litigants in Ancient Athens, Chicago, Illinois 1927,

${ }^{66}$ Anon. (5), "Greek History", p. 31. See also the criticism of Anster, who argued that "amid all the contagious sympathetic influences" a multitude could not take fair decisions, i.e. decisions not created by the "master-spirit of the moment" ("Grote's Greece", p. 484). 
The more spirited of Grote's followers, in this concern, was John Stuart Mill. For Mill, the external policy of Athens had been greatly misjudged. Apart from their tendency for dominion, the Athenians could not be blamed for acts of systematic violence. Instead, it is lamentable that, according to Mill, such an empire was not continued longer. It was an empire that the whole of mankind, "beginning with the subject states themselves", had reason to thank. ${ }^{67}$ The subject states had few practical grievances, ${ }^{68}$ and their tribute was low enough when compared with the efficient military and naval protection which they received. Mill proceeded to argue that their main complaint, grounded on feelings of freedom and dignity, was well-grounded. Yet, Mill continued, given their material incapacity to retain their autonomy against the allpowerful Persian threat, their estimate of autonomy was ill-conceived. It was exactly "this narrow spirit of independence ... which ultimately caused the ruin of Grecian freedom by the absorption of all Greece into the Macedonian monarchy". ${ }^{69}$ Like Mill, George William Cox, an historian deeply influenced by Grote, remarked that the subject allies had no practical reason to complain against Athenian rule. In his view the imperial control of Athens "pressed on the allies as a sentimental rather than as a real grievance". ${ }^{70}$ Curtius believed that the Athenians did not impose any "undue

${ }^{67}$ Mill, C.W., vol. XI, p. 321.

${ }^{68}$ Athens, according to Holm, "allowed her allies complete intellectual liberty" (History of Greece, vol. II, p. 219). In Duruy's judgment, Athens established its empire "without deeds of violence, rapine, or cruelty", like the Spartans (History of Greece, vol. III, 2:486). 1134.

${ }^{69}$ Mill, "Grote's Greece, The Spectator (10 March 1849), C.W., vol. XXV, p.

${ }^{70}$ G.W.Cox, The Athenian Empire, London 1888, pp. 92-3; see also his History of Greece, vol. II, p. 72. 
burdens" upon their subjects..$^{71}$ Freeman, reconsidering the Athenian empire, arrived at the conclusion that Athens acted on the basis of a strong feeling of hellenism, and stood above the local influences inherent in Greek customs. ${ }^{72}$

Following the Pseudo-Xenophon's judgement, historians before Grote pointed out that one of the harshest practical burdens imposed upon the subject-allies, and one which reduced considerably and justly their feeling of autonomy, was the Athenian interference in their judicial procedures. Grote, as shown earlier, defended the Athenian jurisdiction over the allies. In the period which commenced with Grote's work, most historians justified the Athenian interference. Whibley whose work breathes an admiration for Grote's accomplishment, argued that the jurisdiction of Athens over the cities of the league was beneficial to the greater number of the allies. "Not only was there a settled state of peace within the league, but there was a security of person and property, and a protection for the people against the oppression of the rich oligarchs and against the injustice of Athenian officers" ${ }^{73}$ Holm believed that Athenian jurisdiction was advantageous for the subject allies because it secured more impartial justice than it was possible to obtain in the native cities. ${ }^{74}$

${ }^{71}$ Curtius, History of Greece, vol. II, p. 516.

72 Freeman,"Grote's History of Greece", pp. 167-8. Cox believed that the Athenians "were working to make a nation" (The Athenian Empire, p. 220).

${ }^{73}$ Whibley, Political Parties in Athens, Cambridge 1889, pp. 29-30. Similarly see Cox, History of Greece, vol. II, p. 74; P.Smith, History of the Ancient World, London 1873, vol. I, p. 507. R.Meiggs recently affirmed that Athens relied "on the law-courts rather than force although she ha[d] the power to coerce and might be expected as an imperial power to be impatient of the law" (The Athenian Empire, Oxford 1972, p. 228).

${ }^{74}$ History of Greece, vol. II, p. 217. 
Freeman pointed out Grote's successful clarification of the two periods in the history of the empire. The voluntary confederacy of Delos was transformed gradually to the political supremacy of Athens, which though not positively oppressive, was offensive and repugnant to Greek political ideas. ${ }^{75}$ This 'gradual transformation' of the nature of the alliance, Whibley argued, "was the inevitable result of circumstances", and Athens was not guilty of a preconceived plan. ${ }^{76}$ According to Lewis, the transition from a voluntary hegemony to imperial rule "has never been so well written, or half so well explained, as by Mr.Grote". ${ }^{77}$ Goodwin argued that Grote's important distinction was a historical reality which was often overlooked. The Delian confederacy secured the independence of the numerous islands in the Aegean. But subsequently these islands, carrying "the idea of independence even to an absurdity", gave up their participation. Thus the Athenian leadership gradually changed into the Athenian empire. No particular step towards the formation of that empire could be considered the determining factor; still the result, with the growing unpopularity that grew out of it, prepared the ultimate ruin of the glorious city. ${ }^{78}$ Smith, who was fully in agreement with Grote, highlighted a point which Grote, himself, would have found the most important. All the movements of revolt, he pointed out, originated with the oligarchs and the aristocrats, and not with the poor

${ }^{75}$ Freeman, "Grote's History of Greece", pp. 168-9.

${ }^{76}$ Political Parties in Athens, Cambridge 1889, p. 25. Duruy similarly emphasized that the "change resulted from the nature of things", and was inevitable (History of Greece, vol. II, 2:570).

${ }^{77}$ Lewis, "Grote's History of Greece" (I), p. 150.

${ }^{78}$ Goodwin, "Grote's Greece", pp. 165-6. 
majority of the people, who felt towards the empire, neither hatred nor attachment, but simple indifference and consent to its existence. ${ }^{79}$

\section{IV}

\section{The Demagogues}

Grote's defence of the demagogues, primarily in the name of Cleon, ${ }^{80}$ was much debated. Two aspects of the case came to be stressed. First, the injustice done to the image of Cleon by Thucydides and Aristophanes; and secondly, the important function of a demagogue in the newly-born democracies.

But before we examine the positive reception of Grote's argument, let us consider the protest of an eminent Cambridge Professor, Richard Shilleto. The character of Shilleto's argument was clearly reminiscent of the spirit in historical research which prevailed before Grote; and as such showed that Grote's liberal point of view was not acceptable to all British scholars.

In the beginning of his pamphlet Shilleto thought important to confess that he had opened and read throughout Grote's volume with great prejudice against its author, "the prejudice of one not ashamed to call himself a Tory against one not (I believe) ashamed to call himself a Republican - of one proud of an Academical Education against one disregarding such a position" ${ }^{81}$ Shilleto's declared purpose was to defend Thucydides' reliability as a historian against Grote's assertion that he

\footnotetext{
${ }^{79}$ W.Smith, "Grote's History of Greece", p. 94; see Grote, History, 6:203, 208-9.

${ }^{80}$ It was the defence of a man, who even Hobbes described as a "turbulent but eloquent Athenian", whose "cruelty and baseness of ... disposition is fully shewn in [his] speech" (Thucydides in English (Hobbes' translation), London 1824, p. 130n).

${ }^{81}$ Shilleto, Thucydides or Grote? Cambridge and London 1851, p. 1.
} 
had misinterpreted a number of Cleon's intentions, because the latter had induced the Athenians to condemn him into exile. Thucydides' supposed exile, according to Shilleto, as an historical fact, rested upon no adequate authority. It might have been a voluntary rather than a legal exile. ${ }^{82}$ To support his idea of a voluntary exile Shilleto naturally felt that he had to show why the Athenians should have reasons not to banish the great historian. His explanation, however, was not quite plausible. Grote had argued that Amphipolis' loss produced alarm and dismay and increased the hopes of the enemies of Athens. Shilleto maintained that the Athenians were ignorant of the importance of the position of Amphipolis till it was too late, and therefore they did not reckon its loss a severe blow. ${ }^{83}$ Shilleto's historical explanation was manufactured rather than inferred by the proved facts of Greek history. His primary aim was to attack Grote: he, himself, confessed in the end that he was thankful that the author of this history "is not a member of either of the old Universities of our land". ${ }^{84}$ His hostility to Grote was plain and provoked Goodwin to speak of "the insolent pamphlet of Mr.Shilleto, who seemed to consider Mr.Grote's classical

${ }^{82}$ Shilleto's argument rested on Thucydides own testimony. He said that "xynebe moi pfeugein ten emautou ete eikosi meta ten es Amphipolin strategian" (V.26). Shilleto argued that the word 'pfeugein' is not clearly indicative of the form of pfyge (Ibid., p. 5).

${ }^{83}$ Shilleto, Thucydides or Grote? p. 14. Cf. Grote, History, 5:324-34; and Cox, History of Greece, vol. II, p. 251; and Greek Statesmen, New York 1886, pp. 148-9.

${ }^{84}$ Ibid., p. 21. It is not impossible, stated Shilleto, "that the foregoing strictures may provoke an unfriendly reader to say that I have been dipping my pen in gall as well as in ink. I may be so, but I would not desire to re-write a single sentence" (p. 32). Such a hostile attack on Grote bitterly recurred twenty years later by John Ruskin, who excluded Grote from Sir John Lubbock's list of the 'one hundred best books'. In this decision he was led by his conviction that "there is probably no commercial establishment between Charing-cross and the Bank whose head clerk could not write a better one if he had the vanity to waste his time on it" (quoted in G.M.Royce, "Ruskin vs. Gibbon and Grote", New Englander and Yale Review, 45(1886):954). 
criticism as a daring trespass of an outsider upon some private property of the University of Cambridge"; and Mahaffy about his "foolish hostility to Grote". 85

It is interesting that John Grote, brother of the historian, assumed the task of Grote's defence. His reply to Shilleto's criticism was dictated, as he admitted, partly "by a feeling of justice in respect of Mr.Grote's History, which ... Mr.Shilleto has handled most offensively and most ungenerously", and partly by his desire to defend the reputation of the University of Cambridge as a source of intelligent classical criticism - a reputation unavoidably injured. ${ }^{86}$ John Grote reproved Shilleto for the pompous title of the pamphlet, which prepared the reader to presume Shilleto as the patron of Thucydides. Such a title was further offensive to Grote whose admiration for Thucydides animated his researches. Shilleto, in John Grote's judgement, assumed an unwarranted dogmatism, and his reference to party prejudices are suggestive of his own insincerity, but not of George Grote's, who never alluded to his own party feelings. ${ }^{87}$ Regarding his defence of Thucydides, Shilleto undoubtedly failed. His effort to 'rescue' Thucydides, with his arrogant announcement, appeared to John Grote as a good "specimen of Cleonic couphology [kouphologia: light talking]", which occasions merely laughter. ${ }^{88}$ We might dislike Cleon, John Grote argued, for being the opponent of peace, but George Grote had tried to show that his attitudes were in

\footnotetext{
${ }^{85}$ Goodwin, "Grote's Greece", p. 167; Mahaffy, History of Greek Literature, vol. II, Part II, p. 118.

${ }^{86}$ John Grote, $A$ few remarks on a pamphlet by Mr.Shilleto entitled "Thucydides or Grote?", Cambridge and London 1851, p. 1.

${ }^{87}$ Ibid., pp. 4-5.

${ }^{88}$ Ibid., pp. 18-9. Shilleto's effort can be called, in J.Grote's view, a "comedy of 'Thucydides Rescued'" (p. 26).
} 
accordance with the politics of Pericles. Cleon was the real successor of Pericles. "Adding the element of biaiotes to the character of Pericles, we seem to have that of Cleon"; and removing Pericles' aristocratic lineage we have Cleon's position. Yet, J.Grote disallowed his brother's portrait of Cleon as an opposition leader, since this modern concept implies very little actual direction of political affairs. ${ }^{89}$

Freeman admitted that "no part of Mr.Grote's History took the world more by surprise, than his elaborate vindication of Kleon". 90 Grote's account, wrote Freeman, was plausible, though it seemed paradoxical. Most importantly, Grote succeeded again in interpreting the Athenian feeling that urged the banishment of Thucydides. Grote "dared for the first time" to argue that Thucydides' commentary was coloured by his prejudice against his personal enemy. In the case of Cleon, the venerable historian, Freeman believed, abandoned his unimpassioned narrative style. "We may freely allow that for once the impartiality of Thucydides failed him."

Mill and Goodwin agreed with Grote's argument. Cleon had been unfairly dealt with by historians. Though the facts narrated by Thycydides must be accepted as authentic, his judgement on them appears to be prejudiced. ${ }^{92}$ The British Quarterly reviewer similarly concluded that Cleon was misrepresented by those who had a bitter personal enmity against him. Aristophanes' portrayal of Cleon cannot be supposed as

${ }^{89}$ Ibid., pp. 30-34.

${ }^{90}$ Freeman, "Grote's History of Greece", p. 165.

91 E.A.Freeman, Historical Essays, London 1889, pp. 112-3; see also p. 119. Similarly Cox remarked that Thucydides' short references to the name of Cleon are "marked by his personal animosity to the man" (History of Greece, vol. II, p. 208).

${ }^{92}$ Mill, C.W., vol. XI, p. 331; Goodwin, "Grote's Greece", pp. 169-70. 
generally accepted by the Athenians..$^{93}$ Aristophanes' Cleon, according to Cox, as "the unprincipled schemer who gains influence by pandering to the vices of the people", could not be more untrue. ${ }^{94}$ Champlin, in his turn, doubted whether Aristophanes' representation of Cleon is to be accepted; if yes, then why not his statement of Socrates? ${ }^{95}$

Next, Grote succeeded in exhibiting the role of Cleon, and the demagogues generally, in ancient democratic politics. Cleon was a member of this class of patriots, who defended with sincerity the interests of the populace, and fought against corruption and injustice. The Athenian demagogue, Emerson believed, was the guardian against the violation of law and justice by the rich. ${ }^{96}$ The demagogues assumed the responsibility to champion the interests of the people, in a community where they were exposed to the fluctuating will of the aristocrats. ${ }^{97}$ In ancient Greek society, where pecuniary corruption was common among the leading men, it was important that some men kept a persevering check upon the holders of public offices. This was exactly the demagogic function. ${ }^{98}$ Whibley, one of Grote's successors,

${ }^{93}$ Lewis, "Grote's History of Greece" (II), p. 324. Holm, following Grote, argued that Aristophanes' authority "is not higher than that of a modern comic paper" (History of Greece, vol. II, p. 450). Ranke argued that Aristophanes' picture of Cleon had as its sole support "the inventive malice of the poet" (Universal History, pp. 231, 237).

${ }^{94}$ Cox, History of Greece, vol. II, pp. 164, and 273-4n.

${ }^{95}$ Chaplin, "Grote's Greece", p. 500; see also Goodwin, "Grote's Greece", p. 169.

${ }^{96}$ Emerson, "Grote's History of Greece", p. 62.

${ }^{97}$ See Holm, History of Greece, vol. II, pp. 367, 390 n.3. Cox similarly defended Cleon's policy both in the case of Mytilene and the debate on peace (History of Greece, vol. II, pp. 166, 208). Cf. Curtius, History of Greece, vol. III, p. 124.

${ }^{98}$ W.Smith, "Grote's History of Greece", p. 90. 
argued in favour of the role of the demagogues in ancient democracies. He went on to give an account of the demagogues' sphere of action. They undertook to censure and prosecute corrupt magistrates, and employ their talents in bringing to trial those suspected of oligarchic designs. The Athenians lived in constant fear of such plots "as the oligarchs were thoroughly disloyal to the constitution". Cleon, Whibley maintained, followed the example of Pericles. ${ }^{99}$

\section{$\mathbf{V}$}

\section{Ostracism}

Most of the reviewers acknowledged that Grote had made a good point in defending ostracism as a constitutional safeguard given political insecurity. Ostracism prevented disastrous party-struggles, and as George Rawlinson argued, "preserved the state from all attempts upon its liberties". ${ }^{100}$ Bain remarked that ostracism was "a mild substitute for impeachment", ${ }^{101}$ and Lewis asserted that the history of the Athenian republic did not show that this institution emerged from the jealousy of the populace, or the defects of democracy. ${ }^{102}$ In his History of Greece Cox defended the purpose of the institution of ostracism, and claimed, echoing Grote, that it provided the means to the "growth of constitutional morality in the whole body of the

${ }^{99}$ Whibley, Political Parties in Athens, pp. 64, 65, 69.

${ }^{100}$ George Rawlinson, A Manual of Ancient History, Oxford 1869, p. 173.

${ }^{101}$ Bain, Minor Works, p. [84]. See also, Freeman, "Grote's History of Greece", p. 161; Lewis, "Grote's History of Greece" (I), pp. 138-9; W.H.Smith, "Grote's History of Greece", p. 145; Champlin, "Grote's Greece", p. 498.

${ }^{102}$ G.C.Lewis, "Grote's History of Greece" (II), p. 319. 
citizens". ${ }^{103}$ Grote's argument in defence of ostracism had also an influence in Germany. Schomann, whose interest in Grote's work is not to be doubted, argued that ostracism was a mild measure against those who endangered the constitution. That procedure, he continued, "showed more forbearance towards the persons affected, than was usually the case either in tyranny or oligarchy". ${ }^{104}$

Felton and Anster argued against Grote's approach to ostracism. Felton readily admitted the ingenuity of Grote's arguments, but a single consideration, he held, could overthrow them all, namely that "the principle of ostracism was essentially unjust. Surely mollusks never were put to so ill a use, before or since". ${ }^{105}$ Felton, however, never explained what he meant by 'unjust'. Anster, who was generally critical of Grote, argued that what he himself was inclined to conclude was not "that the ostracism was good because it was essential to the democracy, but that democracy was bad because it necessitated the ostracism". ${ }^{106}$

VI

\section{The Spartan Character and Constitution}

The historians of the post-Grotean period tended to emphasize the weakness of all aspects of the Spartan model especially as compared with the Athenian. According to J.S.Mill, the Spartan citizens, "those hereditary Tories and Conservatives

${ }^{103}$ Cox, History of Greece, vol. I, pp. 230.

${ }^{104}$ Schomann, The Antiquities of Greece, p. 182. Similarly see anon. (1), "Grote's History of Greece", pp. 294-5.

${ }^{105}$ Felton, "Grote's History of Greece", p. 301; and Greece, Ancient and Modern, Boston 1867, vol. II, pp. 108-9.

${ }^{106}$ Anster, "Grote's Greece" (II), p. 487. 
of Greece", were the most "rapacious and corrupt of all Greeks". ${ }^{107}$ During the ascendancy of their country they revealed that despite their ascetic education, or by a natural reaction from it, they could not easily renounce the temptations of luxury and private interest. The Spartan model, Mill asserted, wanted its citizens to become "creatures and instruments of the ideal being called the State". ${ }^{108}$ Thus, individual life and private property were sacrificed to that purpose. Lewis, in the same spirit, pointed out that the Spartans were "stiff, unsocial, dry, austere, illiterate"; yet, he remarked, under the new criticism, the Spartan character appeared so unattractive that there was a danger of underestimating it too much, as compared with the Athenian. ${ }^{109}$ It is worth observing, nevertheless, that Lewis himself two years later would have argued that the Spartan, though brave as a warrior, and readily submissive to a severe discipline, was at the same time "haughty, imperious, ignorant, narrowminded, fierce, cruel, pedantically attached to routine, and ... most accessible to bribery". ${ }^{110}$ The Spartans' system, according to Lewis, disregarded the social dimension of a political constitution. Internal stability was safeguarded by the narrow and restrictive policy of an oppressive oligarchy, by means of terrorism and massacre. ${ }^{111}$ Similar remarks regarding the Spartan character were made in the London Quarterly Review. The Spartan Ephors were vulnerable and inhuman, and their

${ }^{107}$ J.S.Mill, C.W., vol. XI, pp. 302-3.

${ }^{108}$ Mill, C.W., vol. XI, p. 301.

${ }^{109}$ Lewis, "Grote's History of Greece" (I), pp. 126-7.

${ }^{110}$ Lewis, "Grote's History of Greece" (II), p. 307.

${ }^{111}$ Lewis, "Grote's History of Greece" (II), pp. 308-9. Cf. Anster, who defended the Spartan political model exactly on the old rationale, namely, its stability. See,"Grote's Greece" (II), p. 483. 
policy was built on suspicion and mistrust. The virtue of the Spartan citizen consisted exclusively in his military conduct. ${ }^{112}$ The Putnam's reviewer likewise observed that the peculiarity of the political constitution of the Spartans, had dramatically disqualified them for a prudential external policy. The Spartans were strong at home, "like all oligarchies", but they were "weak when they stepped beyond their own territories, or their own specialty". According to the same reviewer the Spartans were a "set of well-organized barbarians"..13

The organization of the Spartan empire was also severely criticized. Sparta deceived its allies. As Curtius argued, the states which formerly belonged to the Athenian rule, instead of enjoying liberty, as they had hoped, were terrified to find themselves heavily oppressed from the Spartan supremacy. ${ }^{114}$ The result of the overthrow of the commercial dominion of Athens was the strict military despotism of Sparta. ${ }^{115}$ The Spartans, in Foster's view, were oppressive and suspicious, and generally interfered with the local government, investing the oligarchs with the supreme authority. More than that, they surrendered the Asiatic Greeks to Persia, anticipating foreign support of their despotism. ${ }^{116}$ Sparta's appointed harmosts,

${ }^{112}$ Anon. (5), "Greek History", pp. 9-11. Similarly see Schomann, The Antiquities of Greece, p. 256. (Note Aristotle's remarks in Pol., VIII.1338b.)

113 Anon. (6), "Grote's History of Greece", Putnam's Monthly Magazine, 8(1856):186.

${ }^{114}$ Curtius, History of Greece, vol. IV, p. 17. See also Rawlinson, Manual of Ancient History, p. 184.

${ }^{115}$ See Duruy's remarks on the Spartan supremacy, History of Greece, vol. III, 2:487.

${ }^{116}$ Foster, "Grote's History of Greece", p. 65. P.Smith spoke with indignation of the "disgraceful 'Peace of Antalcidas" (History of the Ancient World, London 1873, vol. I, p. 549). 
Donne observed, were "more intolerable rulers than the Persian satraps or the Greek despots". Their 'virtues' were generally hostile to human development, and when far from their city, they were converted into sheer vices. The Spartans were grasping and aggressive, uncivilized and extremely self-indulgent. ${ }^{117}$ No redress could be obtained against the various outrages committed by the Spartan harmosts or their favourites. To the many complaints the Spartan government "turned a deaf ear". ${ }^{118}$

\section{VII}

\section{Grote's Achievement}

Grote's History of Greece, despite its radical and 'revolutionary' character, generally met with approval. Initial reservations were the product of the customary trust to original sources and the conservative intellectual climate which characterized the oldest British universities. American scholars, who did not share the same intellectual environment had not even those initial reservations. What was principally appreciated in Grote's work was the successful contextual recreation of Greek life, spirit and politics. It was generally acknowledged as the first attempt to judge the Greeks by their own standards, either religious, social, or political. Grote's assurance that the Greeks, and particularly the Athenians, estimated highly their liberty, and were prepared to fight and die for it, was recognized as a genuine historical sentiment.

${ }^{117}$ W.B.Donne, "Grote on Alexander the Great", National Review, 3(1856):51.

${ }^{118}$ W.Smith, "Grote's History of Greece", p. 95. See also, Mill, C.W., vol. XI, p. 323: "It required the field of Leuctra to avenge the daughters of Skedasus, or appease the manes of the victims of the harmost Aristodemus". G.W.Cox similarly argued that the stern oligarchies imposed by means of commissioners sent from Sparta "refused redress even for the most monstrous iniquities" (The Athenian Empire, London 1888, p. 220). 
Thus, if Mitford and others depreciated and consistently censured their manners, it was because their prejudices, conspicuously at variance with the Athenian temper, did not allow them to conceive the liveliness and vivacity of the Athenian faith in their democratic constitution. For the Athenians democracy was the right constitution; the average Athenian of the fifth century preferred to sacrifice his life rather than to submit himself to political servility; the Athenians believed that isonomia ${ }^{119}$ (equality before the law), and isegoria ${ }^{120}$ (unconditional freedom of speech), constituted the highest contribution of a state towards its subjects. What might have appeared to Mitford as anarchy, for the Athenians was a fundamental law of political existence, which safeguarded individual participation eis ta koina.

There had been an inner contradiction in dealing with Athens: Athens praised by virtue of its splendid civilization, but also blamed for its constitutional framework. But after all, were these two areas so distinct? Some scholars continued to believe that in fact they were, in so far as those who primarily contributed to the glorious Athenian civilization were critics of the democratic system of government, rather than friends of it. Grote would have simply answered that had Plato lived in Sparta instead of Athens posterity might not have known his name. Philosophers, historians, poets and artists found in the fertile intellectual environment of liberal Athens many ways to express their talents.

Grote's History was a great achievement because it overthrew the entire traditional interpretation. For Grote, evidence did not mean an uncritical acceptance of the verdict of existing sources. Evidence was criticism combined with textual

\footnotetext{
${ }^{119}$ Thucyd., III.62.3.

${ }^{120}$ Herod., V.78.
} 
enquiry. Lacking our increased resources and depending almost solely upon his historical sense and desire to render justice to the Athenians, Grote anticipated to an astonishing extent the modern treatment of Greek history. Grote's History remains a monument of historical research. It opened new perspectives and new avenues for the exploration of the depths of Greek politics and Greek civilization.

Grote's History received the recognition and approval of foreign scholars soon after its publication. ${ }^{121}$ It was influential in the development of ancient historical research. In Germany the 'Histories' of Curtius, Beloch, Holm and Shomann, filled the lamentable gap in this field of research, and ended the period of the 'Manuals' like that of Hermann's - which offered only information and abstained from any sort of criticism. As Momigliano pointed out German professors took Grote's challenge seriously. "All the German studies on Greek History of the last fifty years of the nineteenth century are either for or against Grote."122 Hermann Muller-Strubing thought it worthy of Grote's contribution to devote 735 pages defending our historian's position against some of his German critics. ${ }^{123}$

${ }^{121}$ His History was translated in France by A.-L. de Sadous, 1864-7 (19 vols); Germany, by N.N.W.Meissner, 1850-55 (6 vols); Italy, by O.Colonna, 1855-7 (though not completely, 3 vols only). It was also published in America. Extracts of it were published in T.Fischer (ed.), Griechische Mythologie und Antiquitaten, Leipzig, 185660 and Lebens und Character-Bilder Griechische Staatsmanner und Philosophen, 1859. Also in Geist der griechischen Geschichte, ed. Johann Jacoby, 1884.

${ }^{122}$ Momigliano, George Grote, p. 13.

${ }^{123}$ Aristophanes und die historische Kritik, Leipzig 1873. 


\section{APPENDIX \\ Greek Historians and George Grote}

In Greece, Grote was met with the enthusiastic reception of the distinguished 'national' historiographer Konstantine Paparregopoulos. In this country, before the 1840s, historical studies did not properly exist. The foundation of the University of Athens after the revolution gave an additional motive for exploring the vast field of the ancient Greek heritage. It appears strikingly, however, that the Greek historians adopted unreservedly the predominant theories put forward in Germany and Britain.

In his preface to his Istoria tes Palaias Ellados (History of Ancient Greece), Petrides praised Mitford for his "critical aptitude and erudition". He subsequently went on to condemn systematically Athenian democracy and the sophistic movement. ${ }^{124}$ In his judgement "The populace [o ochlos] enjoyed gain as well as pleasure from the subjection of Athens' allies. Everyone's arrogance was flattered ... It was thought that individual pleasure depended on prolonging and extending sovereignty over the allies; passions were further excited by listening to wicked [kakoethes, also immoral] rhetors". ${ }^{125}$

In 1836 a new history appeared, this time by an anonymous writer. In his preface he indicated his sources, where Mitford, of course, prevailed. The other most important figure was the German Heeren. That the writer was influenced by Mitford can hardly be doubted. Mitford's History, he wrote, "is, no doubt, the amplest and

${ }^{124}$ P.Petrides, Istoria tes Palaias Ellados, Korfoi, 1830, vol. I, p. vi. I have translated petrides' "kritiken polymatheian".

${ }^{125}$ Ibid., vol. I, p. 151, my translation. For his judgments on the sophists, see especially vol. I, p. 276. 
most accurate". ${ }^{126}$ The same historian was very critical of Athenian morality; further, he praised Socrates for his moral teaching, as compared with the corrupt sophistic training. ${ }^{127}$

Paparregopoulos was the first, in 1855 , to call attention to Grote's original contribution. The Greek historian spoke with admiration for Grote. In Paparregopoulos' judgement, Grote introduced new elements in the study of Greek history and corrected long-established misunderstandings. ${ }^{128}$ "Towards the right appreciation of these historical issues, we have been supervised by the wise men of Europe, who, during the last fifty years, never tired of illustrating our native history. But we are particularly indebted - i.e. the Greek nation itself is indebted -, to the great [megan] English historiographer George Grote."129 Elsewhere Paparregopoulos gave an abstract of Grote's approach and interpretation of myths, which he seems to have adopted. ${ }^{130}$ The portion of Greek history that deals with gods and semi-gods, he argued, is not fit for historical deductions. ${ }^{131} \mathrm{He}$ also repeated the substance of Grote's argument with respect to ostracism. ${ }^{132}$ Pericles, Paparregopoulos remarked,

${ }^{126}$ Anon., Istoria tes Archaias Ellados, Smyrna 1836, p. d.

${ }^{127}$ For his criticisms of Athenian morals, see, Ibid., pp. 59, 134. For Socrates see, p. 85.

${ }^{128}$ Ibid., p. 21; see also pp. 3n, 7, 12, 29.

${ }^{129}$ I translated from K.Paparregopoulos' Peri tes arches kai tes diamorphoseos ton phylon tou archaiou hellenikou ethnous (On the origins and formation of ancient Greek tribes), Athens 1856, pp. 1-2; emphasis added.

${ }^{130}$ K.Paparregopoulos, Istoria tou Ellenikou Ethnous (History of Greek Nation), Athens 1865 (in 5 vols), vol. A, pp. 40-42.

${ }^{131}$ Ibid., p. 56.

${ }^{132}$ Ibid., pp. 288-290. 
"reminds us of those English politicians, who, from the cares of public life move to the tranquillity of theoretical study - not at the cost of their political duties; for that study in fact provides them with the necessary energy to achieve their practical purposes". ${ }^{133}$ The case of Grote is obviously alluded to.

Further traces of Grote's influence can be detected in G.Mistriotis' works. Mistriotis was a pioneer in promoting Platonic studies in Greece. He edited many of Plato's compositions at a time when Plato was poorly studied in Greece. Grote's achievement is repeatedly praised throughout his works. In his preface to the translation of Plato's 'Apologia Sokratous', Mistriotis called Grote sophon and mega Agglon historikon, i.e. wise, competent and inventive English historian. ${ }^{134}$

${ }^{133}$ Ibid., p. 528; my translation.

${ }^{134}$ G.Mistriotis, Apologia Sokratous, Athens 1876, pp. 7 and 50. See also his remarks on the authenticity of some Platonic dialogues in the edition of Gorgias, Athens 1872, pp. 20-23, 41. On the sophists, see Ta aitia tou archaiou kai tou neoterou politismou, (The origins of ancient and modern civilization), Athens 1891, especially p. 18 where a reference to Grote is to be found. 


\section{Chapter 5}

\section{PLATO AND PLATONISM IN BRITAIN}

\section{AGAINST ENLIGHTENMENT}

To what extent was Plato an object of study in Britain, when Grote embarked on his examination of Plato, and of what kind were these studies? It is a matter of fact that Platonic studies were neglected throughout the eighteenth and part of the nineteenth centuries. As Jenkyns remarks, "Plato began exciting interest at Cambridge in the 1820 s. He did not appear on the syllabus at Oxford until 1847; twenty years later he dominated it". ${ }^{1}$ There was good reason, even in 1865 , to justify Benjamin Jowett's complaint that "There is nothing good, I fear, in English on this subject", i.e. on Plato. ${ }^{2}$ John Stuart Blackie exclaimed a few years earlier, that Plato is not yet studied in England: "Between Plato and the English nation there is in fact a gulf which cannot be passed." ${ }^{3}$ And George Henry Lewes was perfectly right in acknowledging that Plato "is often mentioned and often quoted, at second hand; but he is rarely read". 4 In Germany, ${ }^{5}$ on the other hand, Romanticism opened new

1 R.Jenkyns, The Victorians and Ancient Greece, Oxford 1980, p. 228.

${ }^{2}$ Benjamin Jowett to John Stuart Blackie, 22 March 1865; J.S.Blackie Papers, National Library of Scotland, quoted in F.M.Turner, The Greek Heritage in Victorian Britain, New Haven and London 1981, p. 371n.4.

3 J.S.Blackie, "Plato", Edinburgh Essays for 1856, Edinburgh 1857, p. 6.

${ }^{4}$ Lewes ascribed the disinclination of the English scholars to study Plato in that he is a "somewhat repulsive writer" (A Biographical History of Philosophy, London 1845 , vol. II, p. 30).

5 There is something that almost disqualifies English scholars from appreciating Plato, in Blackie's view; "we are a practical people ... Our genius has a most real, concrete, and altogether terrestrial tendency" ("Plato", p. 5). The English argued 
perspectives for scholars who were concerned with Platonic analysis. In Britain there "were some who regarded Plato not merely with indifference but with active dislike". ${ }^{6}$ The immediate task is to determine the source of this antipathy, or, at best, indifference to Plato's works. It will be suggested that this negative predisposition towards Plato was created by the emphasis laid upon his 'mysticism' and 'intentional vagueness' in the works of those few who had cursorily dealt with his philosophy. An age of common sense was not prepared to accept a philosophy associated with abstruse doctrines and mysticism.

\section{Age of Socratism}

The formation of an unfavourable opinion towards Plato, during the eighteenth and part of the nineteenth centuries, and which discouraged the promotion of Platonic

E.M.Goulburn "are too practical a people, and life ... makes too many demands on our energies, to allow to ordinary persons the leisure of speculative pursuits; but such characters may be found among our neighbours [i.e. the Germans]" (Socrates, A Lecture, London 1858, p. 15). Similarly B.B.Edwards and E.A.Park (Selections from German Literature, New York 1839, pp. 3-5) justified the issue in question in these words: The "Englishman and American are thoroughly Peripatetic; they are ever in motion. They are undoubting believers in the sensible world ... This practical, Aristotelian tendency pervades all things, science, jurisprudence, politics, education, religion ... We love the outward. Our home is in the visible. The Germans are the purveyors of mind. They carry on a commence of intellect. They are psychological adventurers. While we are making ships, they are manufacturing theories ...", etc.

${ }^{6}$ M.L.Clarke, Greek Studies in England:1700-1830, Cambridge 1945, p. 113. Those who assumed the task of analyzing the Platonic dialogues, argued E.Macfait, "have decided against him [Plato] with great vehemence", Remarks on the Life and Writings of Plato. With Answers to the principal Objections against him; and a general view of his DIALOGUES, Edinburgh and London 1760, p. 3.

${ }^{7}$ See D.G.Ritchie, Plato, Edinburgh, 1902, p. 74. "I have followed Grote and Jowett ... in seeking to keep the image of Plato free from Neo-Platonic incrustations" (p. vi). 
studies in the British universities, originated mainly from two tendencies. The first was the unwillingness of scholars to engage in a study of the ancients without first calling attention, in terms exceedingly contemptuous, to their superstitious and idolatrous religion. ${ }^{8}$ Thus, whereas Socrates was in most cases assumed to be a dissenter from the established dogmas Plato was reproached for cultivating other mystical and pernicious notions. ${ }^{9}$ The second tendency referred to the effort of many scholars to disengage Christian theology from long-established connections with the school of ancient Platonism.

Socrates, as a rule, appealed to the most elevated feelings of admiration and praise. His image was poetically adorned in statements full of sentiment and eulogy:

He seems to have been created as an example to man, and as a proof of the excellence at which our nature can arrive. The colours of his character may soften, and may fade, but their unequalled brilliancy cannot be destroyed ... ${ }^{10}$

The name of Socrates was more easily clothed in a Christian, sentimental language, and his sacrifice and inflexible obedience to what he considered just and divine, entitled many writers to compare him with Christ. Socrates, it was widely maintained,

${ }^{8}$ An early specimen of that tendency is to be found in Roger Davies' An Essay in the Socratick Way of Dialogue, on the Existence of a Divine Being in imitation of Tully's 'Tusculan Questions', London 1724, pp. 3-4, 6. A late instance in R.D.Hampden, The Fathers of Greek Philosophy, Edinburgh 1862, pp. 343-8.

9 "While Plato was regarded with little sympathy, a general respect and admiration surrounded the figure of Socrates" (Clarke, Greek Studies, p. 114). E.M.Manasse calls the 18th century "an age of Socratism" ("Platonism since the Enlightenment", Dictionary of the History of Ideas, New York 1973, vol. 3, p.517).

${ }^{10}$ Anon. An Essay on the Character and Doctrines of Socrates, Oxford 1802, p. 22; similarly J.G.Cooper, The Life of Socrates, London 1771, pp. 20-21. 
could be named the 'Christ of heathenism' ${ }^{11}$ He was generally portrayed as a deeply religious man, who firmly believed in the immortality of the soul, and the doctrine of rewards in the ultimate court. As a divine person, living among the corrupt, superstitious and idolatrous Athenians, he laboured incessantly to bring them to "the knowledge of the true God", and to accustom them to acts of piety. In R.W.Emerson's judgement, Socrates was a patriot, "a reformer of the abuses of morals and virtue which had become a national calamity". ${ }^{12}$ The Athenians appear to have been depraved and vicious, and Socrates' condemnation was simply an instance of the unsteadiness of their character. ${ }^{13}$ How such a person was condemned to death was not difficult to understand, granted the fact that extraordinarily gifted persons caused extraordinary enmities, and especially considering "the degenerate age he lived in, and the universal corruption of manners that then prevailed in Athens".${ }^{14}$ It was generally taken as an indisputable matter of fact that the age of Socrates, Periclean Athens, was

${ }^{11}$ See, James Welwood, The Banquet of Xenophon. Done from the Greek, with an Introductory Essay to Lady Jean Douglass, concerning the Doctrine, and Death of Socrates, Glasgow 1750, p. 12: Socrates, according to Welwood died as "a martyr for the unity of God". J.Toulmin argued that Socrates can be considered as a "type of Christ to the Heathens" (Dissertations on the Internal Evidences and Excellence of Christianity: And on the character of Christ, compared with that of some other celebrated founders of Religion or Philosophy, London 1785, p. 30). Blackie called Socrates the "Messiah" of the "Heathen Church" ("Plato", p. 30). Further, see Anon., Phedon: or, a Dialogue of the Immortality of the Soul. From Plato the Divine Philosopher, London 1777, pp. iii, 10; J.P.Potter, The Religion of Socrates. Dedicated to Sceptics And Sceptic-Makers, London 1831, pp. 60-61, and 80; A.Dacier, Plato's Divine Dialogues, London 1839, p. 3.

${ }^{12}$ R.W.Emerson, "The Character of Socrates", Two Unpublished Essays, written in 1820, New York 1895, pp. 23-4. See also Lewis Theobald, Plato's Dialogue of the Immortality of the Soul, London 1713, p. ii (my numbering).

${ }^{13}$ See for instance, Anon., Character and Doctrines of Socrates, p. 10.

${ }^{14}$ Welwood, The Banquet of Xenophon, p. 23. 
the most unprincipled and corrupt age in the entire history of ancient Greece. ${ }^{15}$ The sophists, politicians and demagogues promoted the corruption; Socrates resisted it.

Further Socrates was believed to have erected, on the firm basis of transcendental knowledge, a complete system of morals and politics. Girot, a Frenchman who found in London a responsive public, went so far as to assert that Socrates had established a school of his own. He was a rational dogmatist, who diffused certain positive doctrines. ${ }^{16}$ Scholars ascribed to Socrates a great number of metaphysical and ethical doctrines; ideas and arguments of a positive, and rather dogmatic character, that were taken from Plato and Xenophon and treated as Socratic in substance. In his time Socrates assumed the character of a moral educator: "on moral subjects he always expressed himself with confidence and decision." ${ }^{17}$ At this point scholars showed their antipathy towards Plato. It was often asserted that Plato distorted the authentic Socratic teaching by introducing into Socrates' system various and contradictory influences. Plato was criticized for constructing upon the supreme Socratic teaching an impure superstructure of his own. Xenophon, on the contrary,

${ }^{15}$ See, e.g., H.Spens, The Republic of Plato in Ten Books, Glasgow 1763, p. x; Macfait, Life of Plato, pp. 57-8, 64.

${ }^{16}$ M.E.A.Girot, La Morale Des Anciens, London 1807, pp. 343-4. T.Stanley whose obsolete History of Philosophy was republished several times, in lieu of other comprehensive works on the subject, spoke confidently of Socrates system of "Politicks", London 1743, pp. 73-9. See also E.Edwards (?) The Socratic System of Morals, London 1773.

${ }^{17}$ See J.J.Brucker, The History of Philosophy from the Earliest Times to the beginning of the present century, trans. and abridged from the original Historia Critica Philosophiae, London 1819, vol. I, p. 168. Brucker's work, even in the abridged form in which it appeared in England, requires attention, mainly as one of the major sources of influence prior to Grote's age. Grote mentioned Brucker once in his MS notes; see BL Add. MS 29,514 (1818-1831), fo. 83. On Brucker and his failure to grasp Plato's conceptions, see M.O'Brien, "Modern Philosophy and Platonic Ethics", Journal of the History of Ideas, 19(1958):451. 
committed the doctrines of his master to writing with perfect fidelity and never mixed them with his own ideas. Therefore, he was assumed to be the most trustworthy guide for becoming familiar with Socrates' doctrines and life. Brucker, for instance, was very critical of Plato's purely speculative trend, which, in his judgement, came in radical contrast to Socrates' practical utilitarianism. ${ }^{18}$ Potter believed that the philosophy and the principles of Socrates stood in opposition to the "metaphysical imagination" and "sensual polytheism" of Plato's instructions. He concluded: "Plato's influence has lasted long, but must be eventually overthrown; Socrates' influence, as established by his great pupil, Aristotle, must be more and more extended in proportion as it is understood." ${ }^{19}$

What further exalted Socrates in the minds of English scholars, was his supposed severe opposition to the sophistic movement. The Socratic and the sophistic teachings were regarded as two distinct and unrelated subjects. Scholars adhered to the traditional long-established notion of a polemic between Socrates and the sophists. The sophists hated Socrates, and he despised them. ${ }^{20}$ The latter aimed at enabling people

${ }^{18}$ Brucker, History of Philosophy, pp. 240, 212, 222-3. R.Nares asserted that "Xenophon was he who confined himself in his writings most religiously to the principles of his master" (An Essay on the Demon or Divination of Socrates, London 1782, p. 9). See further, Welwood, The Banquet of Xenophon, pp. 58-9, 95-6; Anon. Character and Doctrines of Socrates, p. 15, 15n. Potter considered Xenophon as religiously recording the Socratic conversations, unlike the "mystic" Plato who had interpolated many theories of his own (The Religion of Socrates, London 1831, p. 10n); similarly E.Pond, Plato, Portland 1847, p. 17, 33.

19 J.P.Potter, The Mysticism of Plato, or Sincerity rested upon reality, London 1832, pp. 47-8.

${ }^{20}$ See, for instance, Spens, The Republic of Plato, pp. xi-xvi; E.M.Goulburn, Socrates, London 1858, p. 37; Pond, Plato, pp. 79, 91; W.A.Butler, Lectures on the History of Ancient Philosophy, Cambridge 1856, vol. II, pp. 27-8. Socrates, according to Dacier, whose work was very popular in Victorian Britain, made the distinguishing purpose of his life to oppose the sophists, who by their "poisonous maxims labour to 
to deceive and flatter in order to fulfil their political and social ambitions. Such a teaching could not but lead to universal scepticism, atheism and hypocricy. Socrates could not suffer remaining inactive at the sight of this growing evil. His teaching, on the contrary, aspired to cultivate the rules of right reasoning and investigation, as well as to propagate the ultimate principles of moral conduct. Socrates, it was argued, fell a victim to the machinations of the sophists, priests, and other pseudo-philosophers of his era, who were threatened at the sight of his growing influence. ${ }^{21}$ The sophists, like the priests, were treated with deference by their contemporaries, and bribed Aristophanes, "a mercenary, witty poet", to ridicule Socrates on the stage, thus artfully turning the Athenians against him. ${ }^{22}$ This kind of argument, namely that Aristophanes was engaged by these men to ridicule Socrates in the Clouds appears very often. ${ }^{23}$

The sophists, themselves, as distinguished from Socrates, were constantly referred to as a wicked and immoral set, or race, or class of men, who had made it their profession to introduce the youth to false reasoning, and in return, received large

corrupt the minds of men, and to destroy truth and good sense" (Plato's Divine Dialogues, p. 14).

21 "In such high repute were these Sophists, that they were liberally supported, not only by contributions from their pupils, but by a regular salary from the state" (Brucker, History of Philosophy, vol. I, pp. 174-5). This argument was repeated by J.G.Cooper, The Life of Socrates, London 1771, p. 20.

${ }^{22}$ Welwood, The Banquet of Xenophon, p. 32, and pp. 33-4. Similarly the German Moses Mendelssohn, who composed a dialogue on the immortality of the soul in imitation of the style of Plato, argued that the sophists, priests, and rhetoricians "hired ... the comic writer Aristophanes to compose a ludicrous piece ... in order to expose [him] to public ridicule and hatred" (Phaedon; or, the Death of Socrates, trans. from the German by Charles Cullen, London 1789, p. xxiv). See Whewell's favourable remarks on Mendelssohn's work, Platonic Dialogues, Cambridge 1860, vol. I, p. 442.

${ }^{23}$ It was Aelian's assertion modified. See Various History, II.13. Stanley believed Aelian, History of Philosophy, p. 85. So did Cooper, Life of Socrates, p. 37; Brucker, History of Philosophy, vol. I, p. 175; and Spens, The Republic of Plato, pp. xi - xvi. 
sums of money ${ }^{24}$ It was very rarely that a scholar should discriminate between some celebrated sophists of an earlier period, like Protagoras and Prodicus, and sophists of a more degenerate kind, usually of later times (fourth century B.C.). ${ }^{25}$ In principle, the sophists were indiscriminately grouped under the odious characteristic of being a set of public corruptors. Explicitly or otherwise, the sophistic phenomenon was closely associated with an historical fact: the growth of democratic constitutions. It was unanimously postulated that their democratic times (it is plain that scholars had Athens in their minds) were times of ethical degeneracy, political factionalism, unprincipled political action, and personal unrestricted ambition. The sophists were, somewhat paradoxically, supposed to have been both products of their times, and partly responsible for this general depravity.

II

\title{
Anti-Platonism
}

As noted earlier Platonic studies in Britain before the 1860 s were in an

\begin{abstract}
${ }^{24}$ See Welwood, The Banquet of Xenophon, p. 24; Mendelssohn, Phaedon, p. v and pp. iv-vii; Toulmin, Dissertations, p. 179. J.Priestley called the sophistic theories, a "wretched philosophy" that Socrates had to expose (Socrates and Jesus Compared, London 1803, p. 11). W.Warburton called the sophists a wretched "Race of men" (The Divine Legation of Moses Demonstrated, on the Principles of a Religious Deist, from the Omission of the Doctrine of a Future state of Reward and Punishments in the Jewish Dispensation, London 1738, vol. I, p. 310). F.Sydenham described the sophists as a sect of professors, a "set of men, smitten, not with the Love of Wisdom, but of Fame and Glory" (The Greater Hippias, A Dialogue of Plato concerning the Beautiful, London 1759, p. 10; the sophists are called elsewhere a tribe, Dialogues of Plato, London 1767, vol. IV, p. 24n). W.Sewell, an Oxford professor, called the sophists a "crew" (An Introduction to the Dialogues of Plato, London and Oxford 1841, pp. 445). J.Forster, called them a "school of wisdom-mongers" ("Socrates and the Sophists of Athens", Foreign Quarterly Review, 30(1843):341-2); and C.Thirlwall "a new class of pretenders to wisdom" (History of Greece, London 1836, vol. III, p. 326; see also vol. IV, p. 259).
\end{abstract}

${ }^{25}$ Like Macfait in the Life of Plato, p. 6; and Forster, "Socrates and the Sophists of Athens", pp. 345, 347; see also p. 367n. 
embryonic stage. Plato, even in that limited scope in which he was analysed, appealed more to the interests of certain groups of scholars; the idealists in ethics, and the intuitionists in science. Plato, as a rule, was involved only in so far as he could lend support to specific theological arguments. What monopolized the attention paid to Plato by almost all scholars was the substance, meaning, importance and implications of his natural religion. Plato was the theologian in either the writings of those predisposed to favour his works or those ready to blame him. This constitutes, I suggest, the main approach to Plato in Britain prior to Grote's works. But especially with respect to Platonic theology there were two distinct tendencies.

First, writers like Warburton, Morgan, Nares and others, ${ }^{26}$ endeavoured throughout their works to invalidate the theory connecting Platonism and Christian theology, thus lending support to the idea of an original Christian system, and exalting the all-powerful, illuminating influence of revelation. ${ }^{27}$ It was principally a reaction against the high repute Plato enjoyed among the Cambridge Platonists, and especially

${ }^{26}$ Warburton confessed his growing uneasiness at the tendency "to represent Antiquity, as Master of all the fundamental Truths our holy Religion has revealed" (The Divine Legation of Moses, vol. I, p. 412). Similarly, C.Morgan, An Investigation of the Trinity of Plato and of Philo Judaeus, Cambridge 1853 (first ed. 1795), p. 150. Jacob Bryant, alluding chiefly to Plato, argued that what ancient philosophers urged on theological issues, "does not at all take off from the necessity of revelation, and the interposition of divine goodness for the improvement and salvation of man" ( $A$ Treatise upon the Authenticity of the Scriptures, and the Truth of the Christian Religion, London 1810, p. 7; see further, pp. 10 and 163). Nares also, in his Essay on the Demon or Divination of Socrates, tried to disprove the alleged internal affinity between Platonic philosophy and Christian theology.

${ }^{27}$ The want of revealed proof is what diminished the authority of Plato. See C.B.Smyth, Christian Metaphysics, or Plato, Malebranche and Gioberti, the old and new Ontologists compared with the Modern Schools of Psychology, London 1851, pp. 10, 16-7. 
Cudworth, who detected in Plato several doctrines consonant with Christian theology ${ }^{28}$ Nevertheless, though Christian sages, like St. Augustine, had insisted upon those affinities, it was also believed that 'infidels' eventually used this sort of argument as proof against the originality and purity of Christian thought. Yet, there were even among their contemporaries scholars of eminence who believed in the essential affinity of the two theological systems. These were a few Scottish scholars who differed from their English contemporaries only to the extent that they followed, more or less, the verdict of the Cambridge Platonists. Spens, who made the first English translation of the Republic, recognized explicitly that what had prompted him to translate Plato was that philosopher's link with modern Christian sentiments, and especially those contained in Revelation. "How wonderful is the correspondence between these sentiments, and some capital tenets in religion; and how striking is the likeness!"29 Not surprisingly, Spens attached to the study of Plato a unique ethical importance; Plato's humanism transplanted in the bosom of the young Britons could have eliminated such current evils, as superstition, ignorance, corruption and barbarity. ${ }^{30}$ Another Scottish scholar, Macfait assumed that it was extremely proper to oppose against the sceptical ungenerous philosophy

\footnotetext{
${ }^{28}$ Stanley believed that Plato had visited Egypt and learned his theology from the Hebrews (History of Philosophy, p. 164). It was originally believed by early Christians (Numenius) that Plato was the Attic Moses, and that he learned the philosophy of Moses from Jeremiah. See Paul Shorey, Platonism Ancient and Modern, California 1938, p. 73. The prominence of the theological element in Plato is also pointed out by Edward Caird, The Evolution of Theology in the Greek Philosophers, Glasgow 1904, p. 162.

${ }^{29}$ Spens, The Republic of Plato, p. xxi. According to Spens Plato's theories have "the greatest conformity with those of Revelation", p. xix, see also p. xxii; similarly Blackie, "Plato", p. 9.

${ }^{30}$ Ibid., pp. v-vi and xxxix-xl.
} 
that is attempted to be revived in this present age; for there is a surprising resemblance between many of the opinions of the ancient sophists and our modern sceptical philosophers. ${ }^{31}$

Plato, in contradistinction, could have inspired sobriety and moderation of sentiments.

The great majority of writers struggled to demonstrate that the doctrine of a trinity did not originate in Plato's mystical writings. ${ }^{32}$ Morgan, for instance, admitted that he never thought of questioning the widespread opinion "that PLATO was acquainted with the doctrine of the Trinity of persons in the divine nature"..$^{33}$ In the process he came to realize that Plato had been, either deliberately or unintentionally, misconstrued. For Plato, first of all, never intended by the term to agathon to express a person, i.e. the Supreme Being, the first person of the Trinity; but rather, the final cause of things. It can be justifiably inferred, in Morgan's view, that a trinity of persons in the divine nature was the genuine doctrine of the primitive Christian Church. ${ }^{34}$ Nothing could prove sufficiently that Plato had even an obscurely formed idea of the mysterious 'trinity of persons'.

The intention of these scholars to disprove the inherited idea of a kind of

${ }^{31}$ Macfait, Life of Plato, p. 78, emphasis added.

${ }^{32}$ Edward Gibbon who attacked that doctrine, argued that it was copied by the Jews, who had freshly settled in Alexandria of the Ptolemies, and cultivated diligently and "embraced with ardour the theological system of the Athenian sage" (The Decline and Fall of the Roman Empire, London 1895, vol. I (ch. XXI), p. 572). See also Priestley, The Doctrines of Heathen Philosophy, compared with those of Revelation, Northumberland 1804, pp. 127-8.

${ }^{33}$ Morgan, An Investigation of the Trinity of Plato, p. iii.

${ }^{34}$ Ibid., pp. 27-35, 149, 150-153. T.Taylor argued that this Christian doctrine was originated in Plato's misinterpretation. See The Works of Plato, London 1804, vol. I, p. Xxxv. Pond declared that he found nothing in Plato which could have been compared to "the inspiration of our sacred books". "Could Platonism endure such a comparison, for a moment?" (Plato, p. 153, and p. vii). 
connection between Platonism and Christianity led them to revive vigorously the notion of an esoteric Platonic teaching. Vague passages in Plato's writings hinted to some of his agrafa dogmata, such as those of Aristotle's reference..$^{35}$ It was assumed that Plato, an abstruse writer, must have had some plausible reason to present some of his ideas clearly and unambiguously. But did he, himself, approve of these ideas? Warburton insisted on the exoteric 'aspect' of Plato's system to depreciate his trustworthiness: the dialogues in which Plato vindicates doctrines which appear to be substantially compatible with those of Christianity were of an exoteric character, ${ }^{36}$ designed to deceive the populace, and serve practical and civil purposes. Warburton's basic postulate was that the doctrine of a future state of rewards and punishments is necessary to the well being of civil society. Plato believed that this doctrine was of use to civil society, and though he disbelieved the doctrine itself, he advocated it in a popular manner. ${ }^{37}$ Utility and not truth was, according to Warburton, the end of ancient religion. Therefore, it appeared lawful to deceive for the public good. It follows that the ancient philosophers said one thing when they thought another. This was the so called two-fold doctrine; the external and the internal: "A vulgar and a secret one. ${ }^{138}$ Those philosophers, therefore, who openly taught the doctrine of a future state had an internal philosophy quite opposite to it. Plato borrowed the double

${ }^{35}$ Aristotle, Phys., 209b.15; De Anima, 404b.7. See also, Diog.Laert. iii.80. This idea has been also supported by two passages in Plato's Letters. See, Second Epistle, 314c; and Seventh Ep. 341c.

${ }^{36}$ Macfait, however, believed that Plato developed esoteric doctrines since he arrived at the knowledge of sublime truths which he thought, justly, improper to expose "to the abuses and contradictions of the vulgar" (Life of Plato, p. 37).

${ }^{37}$ See The Divine Legation of Moses, vol. I, p. 7, pp. 353-5, 385.

${ }^{38}$ Ibid., pp. 308-310. 
doctrine from the Egyptian and Pythagorean practices. Though a believer in the eternity of the soul, a doctrine which upheld in his esoteric teaching, Plato, in reality, rejected the doctrine of rewards and punishments, for he always advocated it in a distinctly popular manner. Warburton's arguments gave rise to a long controversy, which is not of much relevance here. ${ }^{39}$ It should be simply stated that the idea of the esoteric nature of Plato's philosophy predominated (though interpreters differed as to which principles in Plato's philosophy were esoteric) in the eighteenth and the first half of the nineteenth centuries, even among writers rather disinclined to treat Plato with Warburton's severity. ${ }^{40}$ This idea gave an easy 'solution' to problems ensuing from Platonic philosophic complication, or merely deterred potential Platonists.

${ }^{39}$ Some scholars rejected his arguments altogether. See for instance, A.A.Sykes, Principles and Connexion of natural and revealed Religion distinctly considered, London 1740, pp. 399-400: "who can read [the Gorgias], and conceive that Plato did not really believe a State of future Punishments and Rewards?" See also, J.Geddes, An Essay on the Composition and Manner of Writing of the Antients, particularly Plato, Glasgow 1748, pp. 139n, 148-158, 177. The most immediate response to Warburton came from John Jackson, whose first assumption was that even though no religion could be supported without the belief in a future state, "civil society might subsist without it". Jackson acquiesced in the idea that Plato had a two-fold teaching, but he refused to admit that Plato disbelieved the doctrine of rewards and punishments. See, The Belief of a Future State proved to be a Fundamental Article of the Religion of the Hebrews. And the Doctrine of the ancient Philosophers concerning a Future State, shewn to be consistent with reason, and their Belief of it demonstrated, London 1745, pp. 65, 75. See also the anonymous, Critical Inquiry into the Opinions and Practice of the Ancient Philosophers, concerning the Nature of the soul and a Future State, And their Method of teaching by the DOUBLE DOCTRINE, London 1745, which repeated the thesis of the Divine Legation, particularly pp. 95-8; and Jackson's Farther Defence of the Ancient Philosophers, London 1747, p. 70. The difference between the exoteric and esoteric teaching consisted according to Jackson, in a variation of the degree of philosophical complexity: in the exoteric, some notions are represented vulgarly; in the esoteric, the same ideas are discussed and analysed in a more subtle philosophical way. For Warburton the division implied distinct and somewhat contrary elements (opposite propositions), whereas for Jackson it meant only two different explanations of the same notion, addressed to different categories of persons.

${ }^{40}$ See, e.g., Butler, Lectures, vol. II, p. 32. 
The second tendency, related to the treatment of Plato's theology, pointed to it, in a more favourable manner, as a perfect specimen of the attainment of truth by reason alone, thus highlighting the harmony of Christian teaching with rational explanation. Yet scholars of such inclination always gave to revelation the fundamental priority. It was an attempt to highlight the credibility and reasonableness of the doctrines of the Christian religion, by showing their compatibility with the 'unrevealed' power of reason per $s^{41}$

In this context Plato was often accused of lacking consistency, and theoretical coherence. $^{42}$ Plato was usually attacked on a particular ground, and his assumed inconsistency and disunity of thought had its roots not only in his various intellectual influences, or the emphasis he laid on method (Grote's position), but also, and especially, in his mysticism. Though Plato adopted principles of moral and political wisdom, as taught by Socrates, he afterwards obscured their simplicity by

${ }^{41}$ See a good example in Dacier, Plato's Divine Dialogues, pp. 3, 11-12. According to Geddes, Plato proved "all the grand truths concerning the DEITY" (An Essay on the Composition and Manner of Writing of the Antients, particularly Plato, Glasgow 1748, p. 99; see further, pp. 96-7). Cf. Anon. Phedon: or, a Dialogue of the Immortality of the Soul, London 1777, pp. iii, 10, 38, 78n. John Ogilvie, argued that Plato was enabled by means of strict reasoning to 'anticipate' the enlightened theology in many points of great significance, and even asserted that Plato had formed some idea of a trinity. See The Theology of Plato compared with the Principles of Oriental and Grecian Philosophers, London 1793, pp. 16-8, 38, 62, 138, 201-202. See also C.Ackermann, The Christian Element in Plato and the Platonic Philosophy, Edinburgh and London 1861 (first German ed. 1835), p. 31. Sydenham argued that Socratic philosophy, represented by Plato, illustrates the great "Truths of Universal and Natural Religion" (Dialogues of Plato, vol. IV, p. 79n).

${ }^{42}$ See, for instance, Brucker, History of Philosophy, vol. I, p. 225; Anon., Character and Doctrines of Socrates, p. 15. J.Priestley attacked Plato on the ground of his being "perfectly unintelligible" in many respects (The Doctrines of Heathen Philosophy, p. 125). According to Warburton Plato committed his theories to a "monstrous Misalliance", i.e. he endeavoured inconsistently to produce a philosophy out of Pythagoreanism and Socratism (The Divine Legation of Moses, vol. I, p. 350). 
intermingling them with intrinsically antithetical doctrines. Not surprisingly, writers like Sydenham ${ }^{43}$ and especially Taylor, who boasted of penetrating the Platonic mystical mind and of comprehending his divine mania, argued enthusiastically that Plato was consistent and systematic in the exposition of his doctrines. ${ }^{44}$ It should be added however, that the last-mentioned scholars deserve some esteem for the promotion of Platonic studies in Britain. Whatever their defects in approach, what distinguished their efforts was the fact that their interest in Plato arose out of a genuine recognition of his eminence as a philosopher.

${ }^{43}$ Sydenham deserves attention as the scholar who amidst the disappointing indifference towards Plato devoted himself to the task of translating the entire corpus. English readers were, however, unresponsive to his efforts and he, himself, a scholar who was respected both by James Mill and Grote who referred to his name (see Plato, 2:214n.g, 331n.z, 541n.o, 591n.q.) in terms of agreement, was arrested in 1787 "for a trifling debt, and died in prison on 1 April" (E.I.Carlyle, "Sydenham, Floyer", D.N.B., London 1898, vol. LX, p. 245). Sydenham in lieu of other critical enquiries, espoused many views regarding Plato and his background, such as were inherited by tradition. See e.g., A Synopsis or General View of the Works of Plato, London 1759, pp. 13-4, The Greater Hippias, London 1759, pp. 10, 22n; The Second Alcibiades, London 1776, p. 15n.3.

44 Taylor completed, very badly, the translation of Plato, after the death of Sydenham. It was against his pompous introductions, and faulty translations, that James Mill, as has been shown in chapter I, addressed his severe criticism. The Platonic philosophy, Taylor contended, "purifies us from the defilements of the passions and assimilates us to Divinity" (The Works of Plato, London 1804, vol. I, p. iii; also pp. xxiii, and lvii). See further, respecting his estimate of the content of the Platonic philosophy, The Commentaries of Proclus on the Timaeus of Plato, London 1820 , vol.I, p. v. For Taylor's idealized theory of the Platonic man and philosopher, see Miscellanies in Prose and Verse, London 1805, especially pp. 15 and 24. The place of Christian transcendentalism, as the authoritative means of viewing and appreciating Plato, took, in the treatment of Taylor, the mysticism of Proclus, Plotinus and Porphyry. For several references to Plotinus and Proclus, and their 'correct' interpretation of Plato's esoteric doctrines, see, Collectanea; or, Collections, consisting of Miscellanies, inserted by Thomas Taylor, in the European and Monthly Magazines, London 1806. 
III

\section{Platonic Idealism as Contrasted with Utilitarianism}

In early Victorian times there appeared an increased interest in Plato. This interest had its roots in two sources, one positive and the other negative: the German influence, and the development of utilitarian philosophy. But Plato was again only incidentally studied, and for purposes which did not reflect a pure interest in him as a philosopher. Scholars admired his prophetic philosophic speculation, but also disliked his political ideals. Utilitarian ethics and scientific positivism were now added to Baconian experimentalism (attacked in the name of Plato by Thomas Taylor ${ }^{45}$ ). To these scientific positions, believed to be destructive of pure morality, some writers responded with the idealism of Plato. In the period immediately preceding the work of Grote there was a tendency to interpret Plato and Socrates almost as prophets of Christianity.

It was again taken for granted that the key to understanding Plato's philosophy was the state of Athenian democracy. This practical object was believed to be the clue to Platonism. Platonic philosophy emerged as the chief antagonist to the sophistic teaching and an antidote to the ruinous sensualism and empiricism which were undermining the foundations of society. It also had to counteract the pernicious

${ }^{45}$ Taylor confessed that his arguments will doubtless appear unintelligible to those who "have been nursed ... in the bosom of matter, the pupils of experiment, the darlings of sense" (The Works of Plato, vol. I, p. lxxix, my emphasis; see also, pp. lxxx-lxxxiii). James Mill, admitted ironically that Taylor's arguments excited only his pity; "but when we observe a work of the magnificence and importance of the present [i.e. the dialogues of Plato] committed to the hands of a similar person, our pity is swallowed up in indignation" ("Taylor's Plato", Literary Journal, 3(1804):461). 
tendencies that grew out of the "remorseless tyranny of the Athenian commonwealth" ${ }^{46}$ Plato addressed his teaching principally to the young men of Athens to purify their morality, which had been corrupted by the sceptical principles of the sophists. Sewell contended that Plato's Republic constituted a polity for the education of man, just as the Church is a polity established for the education of Christians. ${ }^{47}$ Plato was in most cases represented as a practical reformer, who struggled against sophistry, political factionalism and democratic frenzy. Sophistry had originated in physical science, and in a rationalistic, licentious society where faith had been replaced by the illusory principle of self-will. ${ }^{48}$ The school of 'modern sophism', it was believed, could find its ancient counterpart in the school of Ionian pre-Socratics as well as in that of the fifth century sophists. Bentham and James Mill were explicitly or implicitly placed among the founders of sophistical schools. Drawing the parallel of England and sophistic Athens, scholars warned the nation of losing the power of moral vision, the immutable standard of right and wrong, without which they were going to perish. Sewell emphatically drew the parallel:

if oral instruction is diminishing, so it was at Athens; if books are multiplying upon us, and books of the most frivolous kind, so it was at Athens; if a shifting and changing of opinion has destroyed all confidence in public men, so it was at Athens. ${ }^{49}$

${ }^{46}$ Sewell, Introduction to the Dialogues of Plato, p. 24; see also, pp. 18-21. Butler commented on Plato's role as a public instructor. See Lectures, vol. II, p. 154. Pond argued that Plato led a life of a reformer. See Plato, pp. 17, 33.

${ }^{47}$ Sewell, Ibid., pp. 62-3.

48 See Butler, Lectures, vol. II, pp. 20-28; similarly, Hampden, The Fathers of Greek Philosophy, p. 353; for his criticism of the Athenian democracy, see especially pp. 207, 213, 300-301, 344, 367.

49 Sewell, Introduction to the Dialogues of Plato, p. 75. 
Plato had become more relevant to England, for his divine and immutable system of moral truth was contrasted with the dangerous excesses of utilitarianism into which "the present and the last age [Bentham's age] ... have universally fallen". ${ }^{50}$ This painful parallel, it was believed, rendered the study of Plato of crucial importance.

Blackie, a friend of Jowett, and himself an eminent scholar, attacked the common opinion about Plato, namely, that he "was a dreamer and a fantastic speculator, who was always wandering among clouds and sunbeams".51 Platonic philosophy, on the contrary, in its grand characteristic tendencies, was, in his view, identical to the Christian faith. In the same spirit Sewell argued that "Whoever studies Plato is treading on holy ground".52 Plato's philosophy emphasized Sewell, "has been a useful servant to the cause of Christianity ... one aided in sinking deep the truths of Christianity ... one fairly met the enemies of Christianity upon the ground of reason". ${ }^{53}$ Georgiana Lady Chatterton pointed out that "It is not so much to Plato as a writer of exquisite Greek, nor merely to Plato as a philosopher, that I ask the reader's attention; it is Plato as a man ripe for that revelation which he seemed to foresee as if prophetically". ${ }^{54}$ Plato's philosophy gave prominence to pure and

${ }^{50}$ Butler, Lectures, vol. II, p. 160.

51 Blackie, "Plato", p. 4.

52 Sewell, Introduction to the Dialogues of Plato, p. 27.

53 Sewell, Ibid., p. 7. See also Butler, Lectures, vol. II, pp. 2, 5, 11, 53; W.Lowndes, Remarks on the Life and Writings of Plato, London 1827, p. 30; and E.T.Griffiths, Plato, as read in English by an Englishman, London 1854, p. 43: Plato's philosophy "leaves man open to divine impulse".

${ }^{54}$ Georgiana Lady Chatterton, Selections from the Works of Plato, London 1862 , p. iv. See also, J.S.Blackie, "Plato and Christianity", North British Review, 35(1861):369-373. 
unworldly emotion, and showed utter contempt of all inferior springs of action which were in the words "expediency, policy, utility".55 Plato, in Blackie's approving judgement, was the "great master idealist", "the great apostle of idealism", and Benjamin Jowett called Plato the 'father of idealism' who is not to be estimated by the theory of Utility. ${ }^{56}$ In the same spirit Hampden called attention to Plato's primary object, i.e. to counteract the "crying evil of those times," the tendency to subject everything to empirical tests. Plato insisted justly on the necessity of the existence of higher criteria than that of sensible experience. ${ }^{57}$ Lewis Tayler stated similarly that

in this age there is a peculiar call for a deeper knowledge of Plato. Some acquaintance with his doctrine of ideas seems needed as a corrective to the tendency, so widely prevalent, to resolve all knowledge into an experimental induction of facts, not only in physical, but also in ethical and political science..$^{58}$

It is clear from what has been presented that a tendency developed as a reaction to utilitarianism, which represented Plato as the master of Idealism, and the critic of scientific experimentalism. Plato established the objectivity of universal truth, and his arguments, it was thought, should have been employed as an antidote to the

${ }^{55}$ Blackie, "Plato", p. 9. Blackie attacked Utilitarianism vigorously in his Four Phases of Morals. Socrates, Aristotle, Christianity, Utilitarianism, Edinburgh 1871, p. 410. Potter defended "Divine Obligation", in the place of a "system of Utility", which was propounded, as he argued, at this transitional period (The Religion of Socrates, pp. i-ii of the 'Dedication').

${ }^{56}$ Blackie, "Plato", pp. 2 and 9; Jowett, Dialogues of Plato, London 1892, vol. I, p. $x$.

${ }^{57}$ Hampden, The Fathers of Greek Philosophy, p. 240. Plato, in Hampden's view, betrays "strong disgust, not unmixed with contemptuous feeling, at the state of misrule into which the democracy of Athens had degenerated in his day" (p. 188).

${ }^{58}$ L.Tayler, Plato Contra Atheos, New York 1845 , p. xi. J.P.Potter similarly made Socrates to take the lead against inductionism and experimentalism, Characteristics of the Greek Philosophers. Socrates and Plato, London 1845, pp. 37-58. 
climate of intellectual scepticism that characterized the Victorian era. But the polemical employment of Plato's philosophy and the repeated appeal to the transcendental dimension of his writings did not allow for progress in the field of Platonic analysis.

Socrates was treated in the traditional way, as a figure of exquisite piety, whose life scholars deemed proper to compare with Jesus. ${ }^{59}$ According to Forster, "To doubt that Socrates believed in One God, is to doubt if Socrates existed". ${ }^{60}$ Socrates, again, attracted a great deal of attention, and a new translation of the dialogues related to him appeared in 1835 . Stanford, who undertook to make the new translation, emphasized in the preface the difficulty and complexity of the subject, for Plato had wrapped in a veil of mysticism his more substantial arguments. ${ }^{61}$ In Henry Cary's view, who prepared the publication of Plato's writings a few years afterwards, Socrates' 'Apology' appeared worthy even of a Christian. ${ }^{62}$ British Scholars, ${ }^{63}$ whose works on Plato differed substantially from preceding ones, and reflected the influence of Schleiermacher and other Germans, still insisted upon the rigid

${ }^{59}$ See, for instance, T.H.Horne, The Deaths of Socrates and of Jesus Christ Contrasted, London 1852, pp. 5, 8-9.

${ }^{60}$ Forster,"Socrates and the Sophists of Athens", p. 361.

${ }^{61}$ C.S.Stanford, Plato's Apology of Socrates, Crito, and Phaedo, Dublin 1835, pp. ii-iii. p. 2.

${ }^{62}$ H.Cary, The Works of Plato, London (Bohn's Classical Library), 1848, vol. I,

${ }^{63}$ Like Forster and Sewell; regarding Plato, Forster followed extensively the interpretation of Schleiermacher; see, "The Dialogues of Plato", Foreign Quarterly Review, 31(1843):489, 472. Schleiermacher's influence on Sewell, an Oxford scholar of distinction, but mostly interested in theological research (he was the author of The Microscope of the New Testament), was obvious. See Introduction to the Dialogues of Plato, pp. 36-7, 111. 
antagonistic spirit, of the sophistic and Socratic teaching. "Alas for that unhappy Sophist", Forster exclaimed, "destined to maintain a moral dispute with Socrates!" The sophistic doctrines were a mass of falsehood and absurdity; Socrates helped the great forms of "Certainty and Truth" to arise out of that very chaos. ${ }^{64}$ Thirlwall argued that the sophists' growing influence gave rise to Socrates' opposition; but the method by which he tried the opinions of others, always careful not to reveal his own, was finally mistaken, and not only by Aristophanes, for sophistic scepticism. ${ }^{65}$ Woolsey believed that the sophists could not fail to "disgust a man like Socrates, who hated show and pretension, and who had a deep veneration for truth". ${ }^{66}$ Lewes again asserted that the sophists, though not sceptics in morals, distrusted the idea of the attainability of objective knowledge. They held that sense-experience constituted knowledge; but they showed also that sense-perception was of an illusory character, and could not be taken as a valid criterion of knowledge; thus they denied the possibility of science. But "Socrates, looking inwards, [found] ... certain irresistible convictions, certain truths of which he could not doubt". ${ }^{67} \mathrm{He}$ always fought the sophists with their own weapons, and on their own ground. The Athenians accused him of impiety and immorality, and

${ }^{64}$ Forster, "Socrates and the Sophists of Athens", p. 354.

${ }^{65}$ Thirlwall, History of Greece, vol. IV, pp. 267-8. The Athenians, Thirlwall believed, displayed a spirit of harsh intolerance; while such a spirit prevailed, it is much more surprising that Socrates' life was so long spared than that he should at last have been prosecuted. See Ibid., p. 273; similarly Grote, History 7:141. Grote believed, however, that such a delay was an unmistakable sign of the Athenian spirit of toleration.

${ }^{66}$ T.D.Woolsey, The Gorgias of Plato, Cambridge 1848, p. xiv.

${ }^{67}$ Lewes, Biographical History of Philosophy, vol. I, p. 216. 
at last condemned him to death ${ }^{68}$ Blackie referred confidently to the "antagonism" between such men as Plato and Socrates and the sophists; the sophistic obnoxious 'worldliness' was decidedly attacked by the two philosophers with their "evangelic trait of ... morality" and their "lofty supersensualism". ${ }^{69}$

A last remark should be made. Plato's philosophy, though invoked to oppose utilitarian ethics, was still not free from hostile criticism. Dislike of Plato was still active, though on a different basis. Earlier scholars had expressed their dislike of Plato on the grounds of his theology; now they expressed it chiefly on the grounds of his political ideals. But their dislike was in substance of a religious nature. His political ideals were thought to have come into sharp contrast with Christian manners and morality. Plato's severity, it was believed, went beyond humanity. His vast generalizations annihilated all individuality, and further endangered the growth of natural affection. ${ }^{70}$ "There is something unpleasant in Plato's character, which finds its echo in his works. He was a great, but not an amiable man; his works are great, but lamentably deficient in humanity."71

${ }^{68}$ The Athenians, according to Lewes, "were volatile, credulous and cruel: all masses of men are; and they, perhaps, were eminently so" (Ibid., p. 201).

${ }^{69}$ Blackie, "Plato", pp. 18, 34. In the same way Hampden argued that Socrates was the "great antagonist" to that "peculiar race of philosophers", who propounded false notions and cultivated immoral speculation (The Fathers of Greek Philosophy, pp. 207-8, 210).

${ }^{70}$ Butler, Lectures, vol. II, pp. 302-303. In Potter's view "a sensual socialism is an integral part of Plato's system" (Characteristics of the Greek Philosophers, p. 101).

${ }^{71}$ Lewes, Biographical History of Philosophy, vol. II, pp. 37-8; see also p. 97: "The ethics of Plato might suit the inhabitants of another world; they are quite useless to the inhabitants of this." 


\section{Remarks - Grote's Position}

Platonic studies, passed, in the period which includes the eighteenth and the first half of the nineteenth centuries, through four stages. No one of the stages dominated the others: each of them contained in itself the characteristics of the old as well as the new. First there was indifference towards Plato, manifested in the absence of systematic Platonic studies in the British universities; 'indifference' to Platonic philosophy may also be another expression for an interest either in the theological or poetical dimension of his writings. The classical education in the eighteenth and part of the nineteenth centuries was, as Clarke remarks, "exclusively linguistic and literary. The undergraduate at Oxford or Cambridge read only a few isolated dialogues of Plato and learnt nothing of his philosophic theories". ${ }^{72}$ Plain indifference gave its place partly to an open hostility towards his theories, or, at any rate, to sentiments of disapproval and intellectual antipathy. It was an outcome of the tendency to treat Platonic philosophy mostly in its Neo-Platonic version, and a pressing desire to disprove its relation with Christian theology. Thirdly, towards the beginning of the nineteenth century, there appeared a vague, and rather indeterminate, interest in the

${ }^{72}$ Clarke, Greek Studies in England, p. 112. See also, Manasse, "Platonism since the Enlightenment", pp. 516-7. The only exception to the rule of general dislike for Platonic philosophy is to be found, as has been already noticed, among a few Scottish scholars, like Macfait, Spens and Geddes. Lord Monboddo approached Plato (in his Ancient Metaphysics, in six vols - 1779-99), as providing the philosophical means against modernity and scepticism. He was an ardent Platonist, and Grote, not surprisingly mentioned him (see Plato, 2:177n.u, 2:184n.f and 3:417n.x.). Lord Monboddo, in a letter to Samuel Horsley (24 July 1780), wrote that the "great obstruction ... to all Ancient Philosophy, in this country, is first the want of the knowledge of the language of it; and secondly the hold which the wretched philosophy of David Hume, has got of the minds of men here" (quoted in William Knight, Lord Monboddo and some of his contemporaries, London 1900, p. 118, emphasis added). 
purely philosophical part of Plato's works, exemplified in the efforts of Sydenham and Taylor. And fourthly, under the German impulse and a burning idealism, there appeared a growing interest in Plato, which, however, did not give birth to works which were equal in comprehensiveness and erudition to those of German scholarship. Until the 1860s works in English partly or exclusively related to Plato which were worth studying were the translations of Tennemann's Manual of the History of Philosophy, Schleiermacher's 'Introductions', and Ritter's History of Philosophy ${ }^{73}$. It was not, of course, accidental that writers who aided the development of Greek studies in Britain, like Thirlwall and Grote, were ardent students of the German scholarship.

It may be tempting to see Grote's work as a direct reaction to the current interpretation of Plato. Yet, there is no sufficient evidence to warrant the assumption that Grote's position, as a Platonist, was one of reaction against his British 'predecessors'. In the case of the History of Greece, as it has been shown, such an assumption might be justified. Grote's Platonic analysis is not intentionally polemical. Platonic studies in Britain in Grote's time did not properly exist. ${ }^{74} \mathrm{~A}$ vague understanding of Plato, as well as an occasional interest in his philosophy were not sufficient to constitute an organized framework of Platonism. It will be seen, of course, that Grote differed in many respects from his British 'predecessors'. The same

${ }^{73}$ We should note, however, a few editions of individual Platonic dialogues; see the scholarly edition of the Philebus by Edward Poste, Oxford 1860; L.Campbell, Theatetus, Oxford 1861; and T.D.Woolsey, Gorgias, Boston and Cambridge 1848; W.Wayte, Platonis Protagoras, London 1854; C.Badham, Platonis Philebus, London 1855.

${ }^{74}$ Manasse observes, with good reason, that modern English Platonic scholarship "was started almost simultaneously by Jowett and by the historian George Grote" ("Platonism since the Enlightenment", p. 522). 
cannot be said with respect to his German predecessors, who indeed, managed to develop a tradition of Platonic research.

The school ${ }^{75}$ of German Platonists which flourished from the last quarter of the eighteenth and extended throughout the nineteenth century can be credited with the first initiatives towards a systematic investigation of the philosophy of Plato. From Tennemann to Hegel and Schleiermacher, and from Zeller to Ueberweg, this school had always something new and original to contribute. Grote was familiar with a great number of works published in Germany, which he often cited. However, his citations were often in terms of disapproval. He was rather critical of the German point of view, though he could not conceal his admiration for the erudition of individual scholars like August Boeckh. ${ }^{76}$ On other occasions Grote followed the German view. In the case of his understanding of Socrates, and the emphasis he placed on his method of investigation, he followed to some extent Schleiermacher, a scholar whom similarly he much appreciated. ${ }^{77}$ It is worth observing that Grote maintained friendly

${ }^{75}$ I call it a 'school' somewhat arbitrarily, since those scholars did not always adopt views in agreement with each other.

${ }^{76}$ See, H.Grote, The Personal Life of George Grote, London 1873, pp. 156-7. Grote, writing to Boeckh on the 12 March 1867, on the occasion of the German professor's retirement, asked him to accept the thankfulness of one of his "foreign brothers-in-hellenism": "Your long and most active philological career has enabled you to extend and improve our knowledge of Hellenic antiquity more than any of your contemporaries, distinguished as several of them have been. Your works, taken together, form an encyclopaedia of philology in all its principal departments", etc. (p. 285). See also, Plato, 1:123na.

${ }^{77}$ See Plato, 1:177n: Grote blamed Hermann for the 'unwarrantably bitter' and polemical tone against Schleiermacher's theory of Plato. Schleiermacher, with whom Grote was at variance, is here said to have been "not only one of the most accomplished scholars, but one of the most liberal and estimable men of his age". 
relations with these eminent scholars, including Niebuhr, throughout his life. ${ }^{78}$

Hegel did not have direct impact upon Grote's thought, as far as his defence of the sophists was concerned, and no signs in Grote's earlier works and manuscript notes indicate a familiarity with his philosophy. In the History of Greece Hegel's name occurred only once, and that in a note which was addressed to Thirlwall. Thirlwall wrote an Appendix to the fourth volume of his History of Greece (1847) reviewing Hegel's theory on the sophists. Grote called attention to Thirlwall's "interesting and instructive review", to point out that he "dissent[s] ... altogether from the manner in which Dr. Thirlwall speaks about the Sophists both in this Appendix and elsewhere". ${ }^{79}$ In the sophistic teaching Hegel saw a transitory historical moment in the process of dialectical necessity, and he was inclined to overstress its sceptical, innovative, side. ${ }^{80}$ Grote, on the other hand, was at pains to prove that the sophists represented the standard beliefs of their age: they "were the regular teachers of Greek morality, neither above nor below the standard of their age". ${ }^{81}$ Grote's unpublished

${ }^{78}$ In a letter dated 26 June 1827 (after Grote's publication of his criticism of Mitford's History in the Westminster Review), B.G.Niebuhr wrote in this spirit: "To see you, Sir, to converse with you on the noble subject [i.e., the Greek history] which occupies your leisure hours, and to which you have already shown yourself so eminently qualified to do justice, will be to me a most exquisite gratification" (Personal Life, p. 53).

${ }^{79}$ History, 7:169n.

${ }^{80}$ See Hegel, Lectures on the History of Philosophy, London 1968, vol. I., pp. 351-448.

${ }^{81}$ History, 7:80-1n. James Hutchinson Stirling criticized Grote in the light of Hegel's theory. See 'Annotations', in A.Schwegler's Handbook of the History of Philosophy, Edinburgh 1867, p. 382. On the differences between Hegel's and Grote's approach to the sophists see the brief account given by A.W.Benn, Greek Philosophers, London 1914, pp. 89-90. 
essay on Socrates, ${ }^{82}$ in which he defended the sophists against Socratic arrogance, proves that his idea of the sophists and Socrates had been formed long before he learned about Hegel and his novel theory. ${ }^{83}$

Grote, I suggest, differed significantly from preceding British scholars in that he positively admired Plato in his primary quality of a philosopher; and further though he disapproved of some aspects of his political theory, he did not reject this theory as a whole indiscriminately. Grote was not hostile to Plato, despite his disagreement with a few of his political proposals. He criticized Plato mostly as an enemy of democratic Athens rather than as a thinker advocating a model of political organisation opposed to his own political philosophy. Though preceding scholars saw Socrates, as well as Plato, fighting against democratic lawlessness (which the sophists encouraged), Grote saw Plato's conservatism turning against the only political system in antiquity which promoted participation and free thought. The sophists, on the contrary, aided the democratic cause. Whereas earlier scholars treated Plato as a mystical writer, who covered his theories under a veil of obscurity, Grote approached him with the instruments of reason and genuine historical interest. Socrates appeared to earlier writers in the guise of a Christian saint, positive and doctrinaire; Grote treated him as a dissenter from the established rules, negative and inquisitive, whose influence in the history of philosophy was rooted in his negative method. Whereas Plato had been attacked for spoiling Socratic philosophy by adding his own spurious ideas to those

${ }^{82}$ See BL Add. MS 29,522 (1825-6), fos. 162-7. It is, perhaps, Grote's earliest piece of writing. The essay must have been written even prior to 1819 , and not in 1825, which is Mrs Grote dating, and meets Clarke's agreement. See George Grote, p. 135.

${ }^{83}$ Hegel is cited sporadically in the Plato: 1:254n.c, 2:178-9n.y, 2:190-1n.p, 2:292n.g. 
of Socrates, Grote went on to argue that there was no consistent Socratic philosophy: his constant philosophic characteristic, namely, his dialectical method of enquiry, Plato exemplified magnificently in his early compositions. Plato was often attacked by British scholars for lacking consistency and theoretical precision; and eulogised by Germans for his systematic coherence which they artfully invented. Grote admired him for his many-sided philosophical 'plan' that aided the development of logic and philosophy as separate subjects of speculation. Let us now look at his analysis in detail. 


\section{Chapter 6}

\section{UNDERSTANDING PLATO}

It has been shown, in the foregoing chapter, that Plato, despite the hostile insinuations against his natural theology, was represented by the leading classicists of Grote's times, and some of the eighteenth- century British scholars, as an aspiring practical reformer, whose foremost philosophical masterpiece, the Republic, was designed to offer an alternative political solution to the disorder and ethical degradation which stigmatized Athenian life. ${ }^{1}$ It has been also pointed out that in the nineteenth century, Platonic philosophy was employed as a means of counteracting empiricism. ${ }^{2}$ Further, the sophists were treated as a 'school', or 'set' of professors who corrupted public morality, encouraged democratic lawlessness, and provided a kind of education which fostered the phenomenon of demagogia. They created a spirit of corruption and debasement, which eventually undermined political structures, i.e. it gave rise to democracy. ${ }^{3}$ Socrates was commonly assumed as belonging to the opposite intellectual pole. He was deemed to be the symbol of ethical excellence, as well as the establisher of a new, clear, and spirited morality. He was the fervent and glorious antagonist of sophism, who opposed relativism and agnosticism, and

${ }^{1}$ See, e.g., W.Sewell, An Introduction to the Dialogues of Plato, London and Oxford 1841, pp. 19, 21, 24, 34, 80; W.A.Butler, Lectures on the History of Ancient Philosophy, Cambridge 1856, vol. II, p. 20. Cf. Grote, Plato and the other Companions of Sokrates (thereafter Plato), London 1865, 1:201.

2 See a representative example in Philip Pusey, "Plato, Bacon, and Bentham", Quarterly Review, 61(1838):480.

${ }^{3}$ See the remarks of the Romantic German philologist, Frederick Schlegel, in the Lectures on the History of Literature, Edinburgh 1818, vol. II, pp. 83-4. 
proclaimed positive doctrines. Grote, in his work on Plato, which he intended as a sequel to his History, ${ }^{4}$ would upset their verdict.

\section{Approach to Plato}

Grote was more than sixty years of age when he embarked on the prospect of "attacking the philosophy of Plato". Some may reasonably think that it is not by accident that he cited on his title page a passage from Plato's Republic, where the Greek philosopher says: "for that is, and ever will be, the best of sayings, That the useful is noble and the hurtful is base. ${ }^{.6}$ Indeed, it appeared paradoxical, and even

${ }^{4}$ Plato, 1:iii. This signifies that Grote was not determined to exclude the historical factor in his criticism of Plato's life and works.

${ }^{5}$ Harriet Grote's expression, which is only partly true, Personal Life of George Grote, London 1873, p. 225 . His manuscripts reveal that he had embarked on the preparation of his work much earlier. See, W.Smith's remark, in "George Grote", Quarterly Review, 135(1873):111. Mrs Grote writing to her sister, F.Eliza von Koch at Stockholm (13 Oct. 1861), mentioned that Grote "is working steadily at his Plato book since 1856, but Lord knows when it will go to press", Lewin Letters, London 1909 , vol. II, p. 243. It actually took "eight long years of labour and study" (vol. II, p. 253). It is very interesting to cite an extract from a letter addressed to Grote by W.Whewell (12 August 1854), which reminds us of Thirlwall's admission of his own inferiority when the History was published. Whewell confessed that he was long endeavouring to arrange Plato's Ethical speculations; and he continued: "Now in all my previous speculations about Plato and his companions, I have found all the views at which I have arrived so completely overpast, and superseded by the clearer, better, and more solidly demonstrated views, which you have given in your History, that it appears to me I am wasting my labour in attempting to do anything which you intend to undertake ... I have no doubt that the effect of what you have written about the Sophists and 'Die Sophistik' will in the end be complete; and that readers in general will wonder how men could be so much misled as the general band of commentators have been" (quoted in H.Grote (ed.), Posthumous Papers, London 1874, pp. 131-2; emphasis added).

${ }^{6}$ Grote cited the passage in Greek. See Republic, 457b (Jowett's translation). See further Grote's "Notes and Extracts from Commonplace Books", Post.Papers, pp. 165 and 195. It is worth noting that Theodor Gomperz argued that "The sober champions 
incongruous, that a scholar who accepted the principles of utilitarianism, and was imbued with the tenets of political radicalism, should become the major contributor to Platonic studies in Victorian Britain. ${ }^{7}$ It can be assumed that a work on Aristotle would have provoked less controversy; ${ }^{8}$ but not a work on Plato, the 'father of idealism' as Jowett and Blackie called him. Grote regarded political factionalism and religious fanaticism as among the major causes, as well as the obvious manifestations, of an intolerant, 'closed' society. Plato had been long conceived as the champion of religious belief, as well as the propagator of aristocratic principles. Grote was thus expected to be Plato's harshest philosophical critic.

Grote, like James Mill, pointed out that Platonic philosophy should have been urgently disentangled from its Neo-platonic version. Plato was seen through the eyes of (to use an expression of James Mill) the 'charlatans of philosophy', the NeoPlatonists. The Neo-Platonists, Grote argued, "introduced a new, mystic, and

of utility and severe rationalism claim Plato for their intellectual ancestor" (Greek Thinkers, London 1905, vol. II, p. 250, emphasis added). D.G.Ritchie also maintained that "In a very true sense Socrates and Plato may be called 'Utilitarians'. It is Plato who defies conservative prejudice by the revolutionary saying that 'the most useful is what should be considered honourable and holy'" (Plato, Edinburgh 1902, pp. 67-8, emphasis added).

${ }^{7}$ As F.M.Turner also remarks, Greek Heritage in Victorian Britain, pp. 286 and 385. See also Bain's remarks in Minor Works, London 1873, p. [117]; and M.L.Clarke, George Grote. A Biography, London 1962, p. 143.

${ }^{8}$ Grote closed his life working on the Aristotle; a work which remained incomplete and published by Murray in two volumes in 1872, after the writer's death. It was received favourably, but Grote managed to deal only with Aristotelian logic. See, E.Wallace, "Aristotle", Westminster Review, 103(1875):84-106; J.S.Mill, "Grote's Aristotle", Fortnightly Review, 19(1873):27-50 (C.W. vol.XI); Anon., "Aristotle", British Quarterly Review, 57(1873):463-484; A.Grant, "Grote's Aristotle", Edinburgh Review, 136(1872):515-558. 
theological interpretation, which often totally changed and falsified Plato's meaning".9 His remark was an implicit criticism of British scholars, and especially Taylor, who had interpreted Platonic philosophy in the light of Neoplatonism. In Germany Plato was approached in a far different way. The famous German school of Platonism, which flourished throughout the nineteenth century, cultivated a distinct methodological tendency, though with two groups (Schleiermacher being the intellectual leader of the first, and Hermann of the second). ${ }^{10}$ Grote attacked this preoccupation with methodology which resulted in (a) the assumption of the existence of an integral system running throughout Plato's philosophic edifice, and (b) the rejection as spurious of a great number of Platonic compositions. In their attempt to arrange the dialogues, German scholars embraced the principle which for convenience may be called the 'artist-like development' of Plato's philosophic system. The philosophy of Plato, Schleiermacher argued, could only be appreciated by the ability of the scholar to estimate "the pervading presence of a purpose in the connexion of his writings". According to Schleiermacher, Plato advanced his philosophical theory in accordance with a preconceived systematic scheme from which he never digressed. It could be detected as a "natural sequence and a necessary relation in these [Plato's] dialogues to one another". ${ }^{11}$ German scholars were striving to detect the inner coherence of the Platonic construction, to uncover its hidden meanings, and expose its perfection. Schleiermacher believed that the Platonic dialogues had been

\footnotetext{
${ }^{9}$ Plato, 1:170.

${ }^{10}$ See Appendix A, attached to this chapter.

${ }^{11} \mathrm{~F}$.Schleiermacher, Introductions to the Dialogues of Plato, Cambridge 1836, pp.
} 5, 18. See W.Lutoslawki's remarks on Schleiermacher, The Origin and Growth of Plato's Logic, London 1897, pp. 48-9. 
disarranged, and they could be restored in their natural, sequential order only by determining what pieces were genuine and what were unauthentic. ${ }^{12}$ The new arrangement should be based on 'internal reasons'. The German tendency led, as is shown in Appendix A, to a dramatic curtailment of the Platonic corpus. The tendency to depreciate the minor, or inconclusive dialogues, in this case by discarding them as spurious, was common among German classicists. Grote objected to the hypothesis of a permeating and systematic philosophic plan in Plato. ${ }^{13} \mathrm{He}$ criticized the German arguments as untenable, and as applying contemporary philosophical ideas in analyzing Plato's dialogues. ${ }^{14}$ Grote did not intend to minimize Plato's philosophic importance. On the contrary, his arguments seem to have been an intentional attempt to emphasize Plato's importance, as far as philosophy as reasoned truth was concerned. Pure Platonism, in Grote's judgement, the Platonism which should animate the spirit of research, and encourage reflection, was that of the negative dialogues, the dialogues which constituted monuments of free thought, and established a philosophical method. Let us examine in some detail the particular aspects of Grote's defence (as he himself conceived it) of Plato's philosophy.

12 Schleiermacher, argued W.L.Blackley who agreed with him, "perceived the incongruity of attributing to an author so far-seeing and so artistic as Plato those minor insignificant dialogues" ("The authenticity of the works of Plato", Fortnightly Review, 2(1867):273).

${ }^{13}$ Plato's dialogues, Grote argued, systematically contradict each other; see his remarks on such contradictions in Plato, 2:455, 472, 619-20. Plato wrote "inferior dialogues as well as superior", (1:207). A positive philosophy cannot be legitimately extracted from dialogues so enigmatic, as the Parmenides $(2: 318 \mathrm{n})$. Further see History of Greece, London 1888, 7:129-130.

${ }^{14}$ See Leo Jubert's praise of Grote's critique, in "Platon et l'ecole Socratique devant la critique moderne", Revue Contemporaine, 47(1865):628-9. 
In Plato, Grote contended, philosophy was conceived as the search for truth. Plato "feels a strong interest in the process of enquiry, in the debate per $s e .{ }^{15}$ The first object in Plato's works was to form inquisitive, testing minds, ready to examine the negative as well as the positive side of a given opinion. Enquiry was rightly estimated by Plato, as valuable in itself. "All his particular discussions seem to be directed with a view to create this dialectical power, and the solution of the immediate topic of inquiry becomes a secondary object."16 Grote believed that the searching element in Plato was preponderant in all dialogues without exception. Plato imparted to his readers an interest in the process of dialectical enquiry "which he evidently felt in his own bosom", and this "constitutes ... one of his principal titles to the gratitude of intellectual men". ${ }^{17}$ But the searching spirit, free and unconditional, stood alone in the dialogues of search. The dialogues themselves, according to Grote, should not be forced into an artificial unity. ${ }^{18}$ Every dialogue should be judged by itself without assuming a consistency between them as an a priori postulate. ${ }^{19}$ The Platonic corpus,

\footnotetext{
${ }^{15}$ Plato, 1:274.
}

${ }^{16}$ BL Add. MS 29,522 (prior to 1832), fo. 9. See also BL Add. MS 29,514 (18181831), fo. 81, where Grote stated that according to Montaigne, Plato's aim was "to improve the disputant not to make good any conclusion"; also Plato, 1:237: "Even in his expository dialogues, he cares little about clear proclamation of results", etc; and 2:399: "to teach positive truth, is only a secondary object."

${ }^{17}$ Plato, 1:276.

${ }^{18}$ Lewis Campbell similarly held that there is no "unity of a plan" in Plato's works. See, The Theaetetus of Plato (copy in Grote's Collection, Univ. of London Library), Oxford 1861, p. ix. Campbell, however, was not always consistent; cf. Ibid., p. lxii.

${ }^{19}$ Plato, 1:497, 2:290. 
he argued, was an aggregate of multifarious works, variable in form and purpose. ${ }^{20}$ Plato's character was essentially many-sided. Plato himself, as portrayed by Grote, was "sceptic, dogmatist, religious mystic and inquisitor, mathematician, philosopher, poet (erotic as well as satirical), rhetor, artist-all in one". ${ }^{21}$ Plato appeared to Grote like the polycephalous animal of mythology, which was in one body, but comprised lots of diverse parts. Instead of forcing the diverse compositions into an imaginary order, on the basis of Plato's fundamental philosophic plan, Grote dealt with them as purposeful in themselves, assuming that in each an element of Plato's character predominated. Plato could be characterized primarily as a poet in the Symposium, as a sceptic in the Parmenides, as a dogmatist in the Republic and the Laws, as a religious mystic in the Timaeus, as a rhetor in the Crito, as a critic of rhetoric in the Gorgias, as a philosopher in the Protagoras, etc.

Grote insisted, however, on the classification of the Platonic works (suggested by Thrasyllus) into two large groups: the dialogues of Search and those of Exposition. ${ }^{22}$ Plato's strictly philosophical character appeared to Grote to have two sides: the negative and the dogmatic or positive. In each group corresponded one side of Plato's philosophic character. The conception of the negative and dogmatic was of importance in Grote's interpretation. It ran throughout his book, and determined the nature of the critical valuation attached to each dialogue under examination. Plato, in his youth, and when he composed most of his dialogues, "considered that the Search
${ }^{20}$ Plato, 1:349.
${ }^{21}$ Plato, 1:214; see also 3:20.
${ }^{22}$ F.Sydenham had divided the writings of Plato into those of the "sceptical kind, and those of the dogmatical" (A Synopsis or General View of the Works of Plato, London 1759, vol. I, pp. 6-7). 
after truth was at once the noblest occupation, and the highest pleasure, of life ... Towards the close of his life ... the love of dialectic ... died out within him. He becomes ultra-dogmatical". ${ }^{23}$ In the negative dialogues, the purely Socratic, Plato recognized full liberty of dissenting reason, essential to any philosophical debate, whereas in the expository dialogues he praised the virtue of passive recipient minds, blindly obedient to external rules. ${ }^{24}$ Grote's eulogy of Plato's negative dialogues (as providing a full philosophic justification of liberty of thought as against convention and social prejudice) as well as his disapproval of the dogmatic writings in which the suppression of dissenting minorities is implicated, possibly betrayed the influence of J.S.Mill's essay On Liberty (published in 1859) on his thought.

The negative dialogues, the dialogues of search, did not coincide textually with the positive dialogues. The positive dialogues should not be taken as designed to furnish answers to difficulties proclaimed elsewhere. ${ }^{25}$ Plato could be treated as a writer whose two currents of speculation, the affirmative and the negative, were independent of each other. ${ }^{26}$ The affirmative theory is

neither generated, nor adapted, with a view to reconcile the contradictions, or elucidate the obscurities, which the negative Elenchus has exposed ... Thus it is that the negative cross examination, and the

${ }^{23}$ Plato, 2:393-4; see also 1:279.

${ }^{24}$ Plato, 1:295, 2:157, 3:335.

${ }^{25}$ Cf. Schleiermacher, Dialogues of Plato, pp. 18-9, and, William Whewell, The Platonic Dialogues for English Readers, Cambridge and London 1861, vol. III, p. vii.

${ }^{26}$ Plato, 1:270. "Plato's affirmative philosophy is not fitted on to his negative philosophy, but grows out of other mental impulses, distinct and apart" (1:273, emphasis added). 
affirmative dogmatism, are ... two unconnected operations of thought: the one does not lead to, or involve, or verify, the other. ${ }^{27}$

The distinction was clearly drawn, and Grote used it in two ways: first, to attack the German theory of a preconceived plan in Platonic philosophy; and secondly, to emphasize his own conception of the scope and role of philosophy, and hence to call attention to the importance per se of negative tests. German critics had diminished the importance of the negative aspect of Plato's thought, not by denying that there was a kind of negativism in Plato, but by the argument that a negative dialogue was the natural preparation for a positive one. No philosophic result could ever be produced, Grote claimed, if this negative vein, admirably exemplified in most of Plato's compositions, was absent. Philosophy could be viewed as a coherent whole only when it combined "the free antithesis of affirmative and negative" ${ }^{28}$ Thus, Grote found the opportunity to censure the depreciation of negative analysis by modern writers, who could not see that the history of science had always contained periods of ignorance and dispute, and that on subjects connected with man and society, "this period of dispute and confusion continues to the present moment" ${ }^{29}$ Dissent was natural, Grote would argue, and negative experimentation, i.e. research without demonstrable results

${ }^{27}$ Plato, 1:292. Cf. Campbell, Theatetus, p. 1xii.

${ }^{28}$ Plato, 3:485; see also 3:478. The negative analysis, in Grote's judgment, supported the development of philosophy as "reasoned truth" for it brought into this sort of reasoning social and ethical topics" (1:260n). The same view was held by A.Bain. See "On Early Philosophy", Macmillan's Magazine, 14(1866):160. In defending his opinion Grote quoted J.S.Mill: "The philosophy of reasoning ... must comprise the philosophy of bad as well as of good reasoning" (3:487, quoted from the System of Logic, Bk. V.I.1).

${ }^{29}$ Plato, 1:494, 3:478. 
(or debate without reaching unanimity), was much better than the imposition of particular dogmatic beliefs in the domain of human life.

Grote went on to defend the unity of plan embedded in each 'negative', or Socratic, dialogue. The minor dialogues, often inferior in style and construction, ended with a negative conclusion, or even with a question. ${ }^{30}$ Plato, Grote maintained, was aware of the perplexity of his dialectical method, as a procedure to the discovery of truth; wherever he was reluctant to submit any explanation he implicitly confessed his inability to do so. "Plato is a searcher, and has not yet made up his own mind: this is what he himself tells us, and what I literally believe." ${ }^{131}$ Plato recognized that the searching spirit, as far as philosophic debate was concerned, was of greater importance than the conclusion itself. Plato, "is anxious to set forth what can be said against a given conclusion; even though not prepared to establish any thing in its place". ${ }^{32} \mathrm{He}$ was more ingenious in uncovering logical difficulties than competent in solving them. ${ }^{33}$ A reader, Grote suggested, should not search for definite answers to particular problems raised by Plato. Grote admitted that "where I find difficulties forcibly dwelt upon without solution, I imagine, not that he had a good solution kept back in his closet, but that he failed in finding one". ${ }^{34}$

${ }^{30}$ Plato, 2:278. Further, Plato "did not always think it incumbent upon him to adapt the end of his dialogues to the beginning" (2:290).

${ }^{31}$ Plato, 1:246.

32 Plato, 2:278.

${ }^{33}$ For instance, the difficulties of the logical puzzles introduced in the Parmenides finally superseded his power of working them out. "He had tied a knot so complicated, that he could not himself untie it" (Plato, 2:297).

${ }^{34}$ Plato, 1:x. 
In Grote's estimation there was a chasm separating the expository and negative Platonic works. The latter category embraced purposefully inconclusive works, which reflected a remarkable awareness of the diversity of human intellectual experience. In them, Plato followed the genuine path of logical enquiry, and adhered to critical and analytical methods. Freedom of thought was clearly vindicated. On the other hand, when Plato propounded a positive doctrine, he proceeded from selfjustifying maxims, overlooking any survey or comparison of particulars. ${ }^{35}$ In constructing a positive doctrine Plato was more of a priest than a rational philosopher. In his positive dialogues Plato forgot the objections put forward in the negative. The second stage, that of exposition, no any longer referred to philosophy (i.e. to philosophy as 'reasoned truth'): Socratic enquiry vanished under Plato's doctrinal authority and self-appealing infallibility.

It has been pointed out above that Grote distinguished between the dialogues of Search and Exposition, ascribing to each respectively one of Plato's intellectual leanings, namely, the searching (of which Grote admired) and the affirmative (of which he usually disapproved). Between these two groups of dialogues Grote detected trivial interrelations, and even between the dialogues of the same group unimportant affinities, basically confined to the similarity of style. Caird accused Grote of "cutting things in two with an axe". ${ }^{36}$ Admittedly, Grote was led to extremes in his desire to criticize the German view of assuming a philosophic unity in Plato. How could he argue, for instance, that the Minos, which he considered as a negative dialogue, was

\footnotetext{
${ }^{35}$ Plato, 1:279, 2:525.
}

${ }^{36}$ Edward Caird, "Plato, and the other companions of Socrates", North British Review, 43(1865):355; similarly, L.Campbell, "Grote's Plato", Quarterly Review, 199(1866):119. 
not related, if not as introductory, at least as thematically relevant, to the Laws, the most dogmatic of the Platonic works? The Cleitophon, an inconclusive dialogue which Grote accepted as genuine, ${ }^{37}$ may also be argued to have been intended as introductory to the Republic.

Grote further considered those dialogues in which Socrates appeared in an affirmative role (e.g. the Republic) as substantially Platonic, or anti-Socratic. Grote doubted whether, in the possession of sufficient evidence, Plato's narrative and Socrates' actual conversations would have been identical. ${ }^{38}$ For Plato was not to be considered as always endorsing the opinions which he ascribed to Socrates; ${ }^{39}$ and he also might have imagined some conversations for the sake of his own argument. Grote warned the reader not to take the words of the Platonic protagonists literally. "Many of the persons cross-examined bear historical names: but I think necessary to warn the reader, that all of them speak both language and sentiments provided for them by Plato, and not their own. ${ }^{40}$ Plato is not to be trusted for his historical accuracy. ${ }^{41}$ Hence, according to Grote, (a) Plato might not have endorsed the theory of Socrates propounded in the Protagoras. Socrates, on the contrary, could be reasonably taken

37 J.Annas recognized the Cleit. as genuine, An Introduction to Plato's Republic, Oxford 1981, p.17; the same did T.Irwin, Plato's Moral Theory, Oxford 1977, p.293, n.33, 4, and G.M.A.Grube, "The Cleitophon of Plato", Classical Philology, 26(1930):302-308.

38 Similarly see, Schleiermacher, "The worth of Socrates as a philosopher", Philological Museum, 2(1833):546, 554-5.

${ }^{39}$ Plato, 2:75.

${ }^{40}$ Plato, 1:290, also 2:36n.

${ }^{41}$ Plato, 1:427, 432. 
(on Xenophon's testimony) ${ }^{42}$ to have expressed his theory. ${ }^{43}$ (b) The dogmatic emphasis in the Phaedo, the categorical generalisation, and the contempt for rational evidence could not be Socratic but were essentially Platonic. ${ }^{44}$ (c) Plato's argument, in the seventh book of the Republic, that the young should not embark on philosophical enquiry, and make use of the method of dialectic, because they would be tempted to argue for argument's sake, is difficult to believe that would find Socrates' approval. ${ }^{45}$ Further (d) Socrates could not be said to hold two contradictory conceptions of Justice. In the Republic Socrates was made to maintain that Justice was good in itself, whereas in the Apology (30b), which Grote regarded as "a report, more or less exact, of the real defence of Sokrates", ${ }^{46}$ asserted that 'ex' aretes chremata', that is to say justice was a potential source, or cause, of happiness to the just agent. ${ }^{47}$

42 "It is to him [Xenophon] that we owe, in great part, such knowledge as we possess of the real Sokrates" (Plato, 3:562). His limited philosophical knowledge was what made him superior in what concerned historical accuracy (3:588-9). Cf. Schleiermacher, "The worth of Socrates as a philosopher", pp. 18, 21; H.Ritter, History of Ancient Philosophy, Oxford 1838, vol. II, p. 42. E.Zeller, Socrates and the Socratic Schools, London 1885, p. 182.

${ }^{43}$ Plato, 3:562.

44 The Phaedo was in Grote's view, to be contrasted with the Apology, Plato, 2:196.

${ }^{45}$ Plato, 3:239 (see Rep., VII.537).

${ }^{46}$ Plato, 1:158n. Grote here followed Schleiermacher; see BL Add. MS 29,522 (prior to 1832), fo. 17. Regarding Schleiermacher's assertion that the Apology was designed "simply to exhibit and record in substance the real proceedings of the case", see his introduction to this work, in W.Smith (ed.) PLATO, London 1858, p. 41. J.S.Mill also defended Schleiermacher's thesis; see $C . W$., vol. XI, p. 151. John Forster agreed here, as in many other points, with Schleiermacher's verdict, "The Dialogues of Plato", Foreign Quarterly Review, 31(1843):472. See W.K.C.Guthrie, History of Greek Philosophy, vol. IV, Cambridge 1975, p. 72: "In Zeller's time this was the prevailing view."

${ }^{47}$ Plato, 3:128. 
(e) The Timaeus was definitely not composed in the true Socratic spirit. In fact, it was a composition which displayed perfectly the "dogmatical pole of Plato's character ".48 (f) A sixth and most important contradiction pointed out repeatedly by Grote was the theory of the Good in the Protagoras as contrasted with the theory Socrates upheld in the Gorgias. In the Protagoras Socrates elaborately asserted that "the Good is identical with the Pleasurable, and the Evil identical with the Painful: in the Gorgias, Sokrates holds ... that Good is essentially different from Pleasurable, Evil from Painful. What the one affirms, the other denies". ${ }^{49}$

Another aspect of Grote's approach was his belief in the authenticity of all the Platonic compositions. ${ }^{50}$ His arguments that "Many of his [Plato's] philosophical speculations are nearly allied to poetry"; that Plato was both sceptical and dogmatical; that Plato's "ratiocinative force is much greater on the negative side than on the positive"; that Plato's character was an aggregate of multifarious, even diverse elements; and that the reader should be prepared to meet varying points of view in "travelling through the numerous Platonic dialogues", led him to acknowledge the authenticity of all the dialogues handed down according to the classification of

${ }^{48}$ Plato, 3:247. See also BL Add. MS 29,522, fo. 63: "This dialogue is exceedingly dark and perplexed - in some places I find it quite unintelligible". Yet, Grote's admiration for Plato is shown even in his examination of the Timaeus, where he confessed that though he has not been able to furnish more than scanty illustrations, "the whole are well worthy of study, as the conjectures of a great and ingenious mind in the existing state of knowledge and belief among the Greeks" (3:283).

${ }^{49}$ Plato, 1:208. The inconsistency is also pointed out by R.Hackforth, "Hedonism in Plato's 'Protagoras'", Classical Quarterly, 22(1928):39-42, and E.R.Dodds, The Greeks and the Irrational, California 1951, p. 198.

${ }^{50}$ For more details see Appendix B. 
Thrasyllus. ${ }^{51}$ It was an attack on German critical severity ${ }^{52}$ which led to a rejection of a great number of compositions. ${ }^{53}$ Grote suggested, in his minute historical survey which took three long chapters of his first volume, that all Platonic compositions were kept, as sacred memorials in the library and museum of the Academy, and then passed to the library of Alexandria through Demetrius Phalereus, who was the chief agent of Ptolemy Soter. ${ }^{54}$ The Librarians of the Alexandriana, among them Aristophanes of Byzantium, classified the writings of Plato, and published them with 'critical symbols'. ${ }^{55}$ Thrasyllus, Grote believed, followed the Alexandrine library as to genuine Platonic works. The classified Platonic Corpus handed down by Thrasyllus was generally recognized as genuine by the Neo-Platonists as well as by Ficinus and Serranus. ${ }^{56}$ It was on the basis of 'internal reasons', i.e. interpretative rules applied to the Platonic philosophic scheme peculiar to each critic (rules usually dictated by an excessive admiration for Plato's constructive skills), that German scholars arrived at

${ }^{51}$ Plato, 1:115, 2:297, 1:212, 2:224, 1:214.

52 "No doubt", argued C.Ackermann, "the severity has been excessive", though he rejected the Laws (The Christian Element in Plato and the Platonic Philosophy, Edinburgh and London 1861, pp. 30-1). In the middle of the nineteenth century, pointed out A.E.Taylor, "especially in Germany, the 'athetizing' of Platonic dialogues became a fashionable amusement for scholars" (Plato the man and his work (first ed. 1926), London and New York 1960, p. 11).

${ }^{53}$ As Gomperz remarked, only "a quarter of Plato's works had survived the ordeal; of the remaining three-fourths each had, by at least one vote, been condemned as spurious" (Greek Thinkers, vol. II, p. 277).

${ }^{54}$ See especially, Plato, 1:146-151.

${ }^{55}$ That is, indicating, where necessary, possible defects in the text. Plato, 1:164.

${ }^{56}$ Plato, 1:170. Even W.G.Tennemann, who wrote at the end of the eighteenth century the System der Platonischen Philosophie, in four vols, Leipzig 1792-5, appears not to have challenged the traditional treatment of the Corpus. Neither Sydenham nor Taylor gave signs of such a tendency in their works. 
the rejection of so many Platonic works. In the words of Davies and Vaughan, contemporaries of Grote, these works were judged "unworthy of so divine a philosopher" as Plato. ${ }^{57}$ Nevertheless, the Thrasyllian classification Grote argued, was more trustworthy than modern critical theories. ${ }^{58}$

It would be useful, before dealing with Grote as a critic of Plato's political theory, to summarize the major aspects of his arguments which formed the basis of his admiration of the ancient philosopher. In his examination of Plato, Grote, unlike his practice in the History, ascribed more trustworthiness to the judgement of ancient testimony $^{59}$ - which, with the exception of the Neo-Platonic sources, did not represent the Greek sage as a dogmatic and affirmative thinker.

(a) Grote succeeded in liberating Plato's image from the mystical and theological chains in which prejudiced British analysts placed it. For Grote such treatment doubtlessly appeared to diminish the importance of Platonic philosophy. (b) He argued that Plato cared little about the proclamation of results, and that his primary object was to protest against uncritical affirmation. Thus, disclaiming the authoritative (positive) character of philosophy, and strengthening its negative arm, Plato, in Grote's view, asserted the free action of the individual mind. ${ }^{60}$ (c) He pointed out that for Plato the distinctions and definitions

57 J.L.Davies and D.J.Vaughan, The Republic of Plato, London 1925 (third ed. 1866), p. vi: Grote, "in his zeal to take Plato down from his superhuman pedestal", was ready to attribute to him these works.

${ }^{58}$ Plato, 1:206.

${ }^{59}$ Cicero, Academics, I.iv.16. The Socratic method followed by Plato led to no positive results. Further Cicero said (I.46) that Plato's position was sceptical, not different from that of the sceptics of the New Academy. See also Diog. Laer., III.52.

${ }^{60}$ Nowhere in ancient literature, Grote maintained, "is the title, position, and dignity of individual dissenting opinion, ethical and political ... so clearly marked out and so boldly asserted" as in the Platonic Gorgias (Plato 2:151). 
in formal logic which he brought to light, at least as far as can be known, were not familiar. Plato, according to Grote, attempted to impress upon his pupils an exact conception of the meaning of general terms and propositions, as well as the mode of defining them. ${ }^{61}$ (d) Grote believed that one among Plato's many discoveries should be listed part of "the general law of mental association". ${ }^{62}$ Grote compared the theory of anamnesis (recollection) in the Phaedo, ${ }^{63}$ with the law of Association as illustrated by James Mill. ${ }^{64}$ Pictures appearing to sensations, Plato argued, give rise to a process of recovering other ideas. According to Grote, Plato stated for the first time, "the important psychological doctrine of the transference of affections by association from one object to others". ${ }^{65}$ (e) Plato's theory of educational technique, i.e. the use of trial, error and exposure, appeared to Grote of great value in enhancing intellectual discipline. (f) Grote rejected the view which conceived of Plato's fundamental task as that of teaching 'Absolute Truth', by means of intuitionism. Plato's ethical speculations, according to Grote, had nothing to do with "the mental intuitions and instincts, assumed by various modern philosophers as common to all mankind".$^{66}$ For Grote, Plato was a sensationalist (Theat.), ${ }^{67}$ who, as the Phaedrus proved, ${ }^{68}$ was not

\footnotetext{
${ }^{61}$ See e.g., Plato, 1:278, 1:324-5, 2:5n.n, 2:563.

${ }^{62}$ Plato, 1:522.

${ }^{63}$ See Phaedo, 73a-e.

${ }^{64}$ James Mill, Analysis of the Phenomena of the Human Mind, London 1825, chapters XXI and XXII.

${ }^{65}$ Plato, 1:523.

${ }^{66}$ Plato, 2:373.

${ }^{67}$ Plato, 2:373.
} 
seriously engaged in the prospect of preaching an 'Absolute'. If Plato had aimed at doctrinal assertions, "we cannot well imagine that he would have left his purpose thus in the dark, visible only by the microscope of a critic". ${ }^{69}$ Thus Grote appeared clearly to have also disputed the traditional view of Plato's having an esoteric teaching. "I see no proof", he claimed, "that Plato had any secret or esoteric philosophy, reserved for a few chosen pupils". ${ }^{70} \mathrm{He}$ also believed that Plato, despite his apparent disagreement with the Protagorean doctrine Homo Mensura, followed it consistently as far as its natural consequences were concerned. ${ }^{71}(\mathrm{~g})$ Plato was the first who conceived, though somewhat dimly, that Utility should constitute the criterion for testing laws and ethical action. "I perfectly agree", Grote admitted, "with the doctrine laid down by Sokrates in the Protagoras"..$^{72}$ The Protagoras was the only dialogue, ${ }^{73}$ in his judgement, that provided a clear answer to the questions of 'what is Good' and what is the object of political science.

${ }^{68}$ Plato, 2:262: "To modify this 'Absolute,' according to the varieties of the persons addressed, would divest it of its intrinsic attribute and excellence."

${ }^{69}$ See History, 7:129.

${ }^{70}$ Plato, 1:231n.x.

${ }^{71}$ Plato, 2:383n.h., 2:513.

${ }^{72}$ Plato, 2:81. Though, as it will be shown, his agreement was only partial. See Ibid., 2:82-3. It may be objected here that at any rate it was Socrates that defended the doctrine of the Protagoras, and not Plato. But for Grote it is Plato who speaks in his dialogues and not his 'actors' for themselves. Socrates' utilitarianism was for Grote indisputable in so far as it is reconfirmed by Xenophon's testimony.

${ }^{73}$ Though elsewhere he appears to identify the Good with the Profitable, as in Alcib.II and the Hippias Major, Plato, 1:360-61. 1:369-70. 


\section{Plato's Authoritarianism Condemned}

Grote did not find too much to praise in Plato's city of the Republic, where he saw the individual suppressed under the assumed infallibility of the philosopherking and the abstraction called the state. In the Republic suppression of individuality, "and conversion of life into a perpetual, all-pervading, drill and discipline - is a favourite aspiration always present to Plato". ${ }^{74}$ However, to understand Grote's criticisms of Plato's politics, one has to turn to his earlier composition, the History, where Athenian democracy is glorified as the first liberal state the world ever saw. Plato's political model came unavoidably to be contrasted with this historical city. His admiration of Athenian democracy led him to judge Plato's politics so strongly.

\section{(i) Plato's Political Aspirations and Athens}

Grote recorded Plato's activity on two occasions, and on both he was critical of his conduct. First, Plato had hoped that he might have played an active role under the tyranny of Thirty. The Thirty had undertaken, as they professed, to eliminate all the evil elements from the city, and to introduce reforms conducive to the improvement of domestic and foreign policy. For Grote, their plans amounted to keeping Athens subordinate to Sparta with Lysander as its main representative. The philosopher Plato, he argued, "then a young man about twenty-four years old, of antidemocratical politics, and nephew of Kritias - was at first misled ... by these splendid

${ }^{74}$ Plato 3:443. Grote's argument reminds us of the Philosophic Radicals' negative conception of the state. See John Plamenatz, Man and Society, London 1963, vol. II, p. 25; G.H.Sabine, History of Political Theory, Illinois 1973 (first ed. 1937), p. 633. 
professions". ${ }^{75}$ Though eventually Plato came to realize their actual motives, ${ }^{76}$ his ardent attachment to their policy in the beginning, contributed materially to strengthen their hand.

Secondly, Grote dealt at length with Plato's relationships with Dionysius the younger - despot of Syracuse. ${ }^{77}$ He pointed out the immense influence of Plato upon Dion, Dionysius' associate. Plato's ability to work upon the minds of young men was impressive. He was a man not only of alluring eloquence, and irresistible intelligence, but also of practical ability. Dion's education under Plato, as well as his company with the sophists of the age, brought a radical alteration in his sentiments regarding tyranny. ${ }^{78}$ Thus he convinced Plato to come into communication first with the elder Dionysius, in an effort to impart to him the 'wisdom' of ruling, and the proper object of the political art. It is well known how disrespectfully Plato was treated; and how fortunate in fact he was to rescue his own person. After the death of the elder Dionysius, Dion acquired the high estimation and confidence of Dionysius the younger. Dion, knowing "the wonderful magic of Plato's conversation when addressed

${ }^{75}$ History, 6:459. See L.Edelstein, Plato's Seventh Letter, Leiden 1966, p. 162. Edelstein argues that Plato strived to made his philosophical views "felt in actual politics".

76 "He was soon undeceived. The government of the Thirty proved a sanguinary and rapacious tyranny, filling him with disappointment and disgust" (Plato, 1:119).

${ }^{77}$ Similarly A.D.Winspear, The Genesis of Plato's Thought, New York 1956, pp. 177-184.

78 History, 9:56-7. It appears clearly that Grote duly acknowledged Plato's antipathy to tyranny (see Rep., 575-76, where the tyrant is designated as the most wicked and miserable of men). He also recognised that Plato did not approve of the effects of the Spartan system upon the character of people (Plato, 2:150). 
to young men", ${ }^{79}$ sent a message urgently inviting him to assist his reformatory plans. Plato, conceiving the great prospective victory which had opened for philosophy, departed immediately for Syracuse. This time he was treated with cordiality and respect, though he had to face at the same time the hatred of some of Dionysius' attendants.

For a moment, Grote contended, "Plato seemed to be despot of Syracuse"; such was the admiration and esteem expressed towards him. But Plato, Grote went on, dealt with Dionysius in a totally inappropriate way.

With all reverence for the greatest philosopher of antiquity, we are forced to confess that, upon his own showing, he not only failed to turn the situation to account, but contributed even to spoil it by an unseasonable vigour. ${ }^{80}$

Instead of instigating Dionysius to political measures advantageous to the suffering people of Syracuse, Plato postponed action, until Dionysius might have attained intellectual maturity. When Dionysius himself announced his will to transform his despotism into a limited kingship, Plato did not encourage him: "First go through your schooling, and then do all these things; otherwise leave them undone." 81 Dionysius soon became weary of education, and, in addition, on the advice of his courtiers, he started suspecting Plato and Dion of treasonous plans. Grote acknowledged Plato's

\section{${ }^{79}$ History, 9:67.}

${ }^{80}$ History, 9:70. Two things are implied in this sentence: first, Grote's admiration for Plato; and secondly, that he himself regretted Plato's unsuccessful dealing with the situation. Cf. Plato, 2:138.

${ }^{81}$ History, 9:72. See Plato, Seventh Letter, 319b-c. 
failure "with sincere regret". ${ }^{82}$ Plato produced results the contrary of those he had intended. Dionysius' future policy became harsher and his tyranny more oppressive. When Dion sought a political career in Syracuse, he had been prepared by the instruction he had received in the Academy. Instead of promoting and securing the restoration of basic democratic forms, he conceived himself as a permanent philosopher-despot. The Academy cultivated in his soul a strong antipathy against pure democracy, and a vigorous inclination towards "a Lacedaemonian scheme of mixed government". ${ }^{83}$ His schemes were rigorously opposed. At this particular juncture Dion misconceived himself in a position to establish himself as a despot. He became strongly hated, and immeasurably unpopular. Kallippus eventually caused him to be assassinated. $^{84}$

This brief outline of Grote's historical account of Plato's political ambitions displays Grote in a rather wavering position, where his disapproval of Plato's conduct in Athens at the end of the fifth century and his 'regret' at the failure in Syracuse alternate. Grote maintained, in the same way, that Plato liked Spartan discipline and the mixed constitution - but disliked their effects on human character. Plato produced works in which the freedom of dissenting opinion had been vindicated in a manner unparalleled in history - but he constantly favoured the suppression of individuality. Grote must have felt a strong sympathy towards Platonic philosophy, at least in so far

${ }^{82}$ History, 9:74. See also Plato, 1:210n.i: "I do not think that he turned his chances, doubtful as they were, to the best account"; and 2:490.

${ }^{83}$ History, 9:117.

${ }^{84}$ Kallippus was one of the members of Plato's Academy. See K.R.Popper's comments on that event, The Open Society and Its Enemies, London 1952, vol. I, p. 136; and R.H.Hare, Plato, Oxford 1982, p. 8. 
as it questioned received and unexamined opinions. Plato's radicalism is manifest in his urging that undisguised reason should prevail when political issues are being considered. But when Grote's two great objects of admiration, the Athenian democracy and Platonic philosophy appeared to conflict, Grote supported the liberal state. The contrast was inevitable:

Athens exhibited marked respect for the sanctity of the person ... much equality of dealing between man and man-much tolerance, public as well as private, of individual diversity in taste and character - much keenness of intellectual and oral competition ... All these elements ... were distasteful to Plato ... To a philosopher whose ideal is depicted in the two treatises De Republica and De Legibus, Athenian society would appear repulsive enough. ${ }^{85}$

(ii) Plato's Political Ideal as Contrasted to Athenian Democracy

The principle of intolerance, Grote argued, "was usually left dormant at Athens: philosophical debate continued active and unshackled, so that the school of Plato subsisted in the city without interruption for nearly forty years until his death". ${ }^{86}$ Yet, at the close of his life Plato, replete with dogmatic vigour, disallowed all liberty of philosophizing to others. Here Plato was treated by Grote as a theoretician who might have possibly envisaged his ideal as a substitute for Athenian democracy. Grote recognized that unlike the sophists, Plato dissented from society, "both democratical and oligarchical, on some of the most fundamental points of public and private morality". Plato longed for the "radical reform of the state, on principles of his own, distinct from every recognized political party or creed". ${ }^{87}$ The Republic

\footnotetext{
${ }^{85}$ Plato, 3:434.

${ }^{86}$ Plato, 3:426; also 2:144-5.

${ }^{87}$ History, 7:38. See also Plato, 3:189, 459-60.
} 
and the Laws were seen through the brightness of Athens, and tested by the logic of utilitarianism.

In criticizing the Republic Grote first turned his attention to the conception of Justice as an end in itself. According to Plato "Justice per se ... is the cause of happiness to the just agent, absolutely and unconditionally". ${ }^{88}$ Thus Plato was led to adopt a theory which was entirely self-regarding: looking to the conduct of each individual alone, as it affected his own happiness, and not as it affected the happiness of others. ${ }^{89}$ Plato might have been led to this theory by the significant fallacy he committed in the Republic, namely, the parallel between the community and the individual..$^{90}$ In the same way Plato in the Philebus inconsistently discussed Ethics upon principles of cosmology or ontology, and drew the parallel between man and the cosmos. $^{91}$

Human beings, Grote proceeded to argue, were full of wants and stood in constant need of the services of others. In adhering to justice in this self-justifying sense, Plato, was in effect contradicting his own theory regarding the genesis and

${ }^{88}$ Plato, 3:129. Self-denial or self-sacrifice are empty words in Plato's theory (3:133). Grote here would side with Thrasymachus who argues that 'justice is the good of another' (Rep., 343c); "Everywhere, both in private dealing and in public function, the just man is worse off than the unjust" (3:36). On the problem of what Thrasymachus conceived in reality to be justice (i.e. another's good, or the interest of the stronger - 338c), see Terence Irwin, Plato's Moral Theory, Oxford 1977, p. 289.n.23.

${ }^{89}$ Plato, 3:133.

${ }^{90}$ Plato, 3:142. Guthrie remarks that the Platonic parallel did not escape Grote's criticisms in his "splendid chapter on it [i.e., the Rep.] ... which should still be read" (History of Greek Philosophy, vol. IV, p. 444). See also R.C.Cross and A.D.Woozley, Plato's Republic, A Philosophical Commentary, London and New York 1966, pp. 756.

${ }^{91}$ Plato, 2:586, 610. 
foundation of society. ${ }^{92}$ No man was completely self-sufficing. ${ }^{93}$ Nor could the Platonic philosopher be called happy without reference to an object or source of happiness, which was not to be found apart from the field of social relationships and social esteem. The theory of justice was relative, according to Grote, and conditioned by the special circumstances and the character of a given society. Socrates for instance, did not enjoy the good treatment and favour of Athens. His 'justice' was not recognized in Athens, and this is why "to call him happy, would be a misapplication of the term, which no one would agree with Plato in making - least of all the friends of Sokrates in the last months of his life".94

Further, Grote went on, the egoistic ethical theory of Plato annihilated social reciprocity. By undermining reciprocity, i.e., by contending "that the performance of obligations alone, without any rights, is delightful per se, and suffices to ensure happiness to the performer", Plato ignored the essential meaning of ethical sentiment. ${ }^{95}$ To act in a certain way might not be a source of delight, though be contributive to the comfort and security of society. ${ }^{96}$ The ancient moralists, he argued in his Fragments, "committed the mistake of looking at morality exclusively from the point of view of the individual, and not from the point of view of society".97

${ }^{92}$ Plato, 3:137.

${ }^{93}$ Plato, 3:147.

${ }^{94}$ Plato, 3:154; see also p.151. Socrates was considered by his fellow-citizens an unjust person, and that explains the rationale of his condemnation $(3: 441)$

${ }^{95}$ Plato, 3:159. Tracing out the consequences of Plato's reasoning, Grote argued, the "authoritative terms right and obligation lose all their specific meanings" (3:137).

${ }^{96}$ Plato, 3:157.

${ }^{97}$ Grote, Fragments on Ethical Subjects (ed. A.Bain), London 1876, p. 33. 
Plato's theory of Utility, as demonstrated in the Protagoras through the mouth of Socrates, was only partially accepted by Grote. In this dialogue Plato again omitted to take account of the individual as a member of society, in which reciprocal relations based on the concepts of duty and right exist, if social union is to endure. ${ }^{98}$ Plato's doctrine, as put in the mouth of Socrates, proposed a strictly selfish calculus of pleasures and pains. But for the computation, according to Grote, to be correct it "must include, to a certain extent, the pleasures and pains (security ${ }^{99}$ and rightful expectations) of others besides the agent himself, implicated in the consequences of his acts". ${ }^{100}$

In discussing the Gorgias Grote pointed out the arbitrary line drawn between the individual and his fellows - the society and his interests. ${ }^{101}$ Socrates was not correct in asserting that King Archelaus had been in a bad mental state, simply because his activities were found to be repugnant: personal feeling should not be the measure of morality. The ultimate determinant was society itself, and its collective interests and happiness. Those historians who attempted to treat the Gorgias as a superior dialogue of Plato's mature age in order to discredit the Protagoras met with

${ }^{98}$ Plato, 2:84. See also BL Add. MS 29,529 (1818-1822), fos. 29-30.

${ }^{99}$ For Bentham on 'security' see Ross Harrison, Bentham, London 1983, pp. $244-$ $5,248,249$ : "Security is 'the principal object of law', the 'inestimable good, the distinctive index of civilisation'".

${ }^{100}$ Plato, 2:83. Grote also mentioned in his analysis of the Gorgias: "That step of Plato's reasoning, in which he asserts, that the wrong-doer when justly punished suffers what is profitable or good - is only true if you take in ... the interests of society as well as those of the agent. His punishment is certainly profitable to (conducive to the security and well being of) society: it may possibly be also profitable to himself, but very frequently it is not so" $(2: 110)$.

${ }^{101}$ Plato, 2:110. 
Grote's disapproval. ${ }^{102}$ They extolled the Gorgias, as recognizing the idea of a superhuman and supernatural Good, existing apart from the pleasures and pains which they regarded among the vulgar ends of someone's life. They adhere to an "Universal Idea, which though it is supposed to cast a distant light upon its particulars, is separated from them by an incalculable space, and is discernible only by the Platonic telescope". ${ }^{103}$

According to Grote, Plato, in the Republic and the Laws, assumed 'the sceptre of King Nomos', and attempted by suppressing all varieties of emotion and intellect to produce a type of character peculiar to his estimate of life and conduct. But his authoritarianism "oversteps all the reasonable aims and boundaries of the political office". ${ }^{104}$ The Republic, in particular, Grote believed, was defective as a political plan in three major respects. First, its strict authoritarianism reduced the polis to an aggregate of officers and commanders rather than citizens: "a sort of military bureaucracy". The individual was abstracted from private feelings and interests. ${ }^{105}$ His feelings were guided and controlled by the "religion of the Commonwealth", 106 and he was destined to be reduced to a "special machine, unfit for any other purpose than its own". ${ }^{107}$ In the Republic Plato appeared as an alien figure. He fell into the same blind conservatism of Meletus and Anytus: "Neither the Sokrates of the Platonic

\footnotetext{
${ }^{102}$ Plato, 2:120.

${ }^{103}$ Plato, 2:131.

${ }^{104}$ Plato, 2:138.

${ }^{105}$ Plato, 3:211.

${ }^{106}$ Plato, 3:187.

${ }^{107}$ Plato, 3:215.
} 
Apology, nor his negative Dialectic could be allowed to exist in the Platonic Republic". ${ }^{108}$ Secondly, Plato did not provide education for all, ${ }^{109}$ as he believed in a natural inequality of abilities. Thirdly, his authoritarian point of view assumed as a matter of course the positive feelings of the persons comprising his polis. But, would they be willingly obedient $?^{110}$ Willing obedience was one of the major achievements of a well-organized and skilful policy.

The same criticisms applied also to the Laws. The same inflexible dogmatism neglect of individual judgement, the same mechanistic conception of human needs and desires, contempt of separate property and family, were characteristics of the Platonic vision. Athens, in Grote's judgement, was unquestionably preferable to Plato's city. ${ }^{111}$ Athens itself was a condition of existence for the dissenting minority. The governing spirit of the Platonic city in the Laws was imbued with a self-satisfied infallibility that called to mind the spirit of "mediaeval Catholicism and the Inquisition". 112

If the Magnetic community had become a reality, the solitary cells of the Platonic Inquisition might have been found to include Anaxagoras, and most of the Ionic philosophers, under the first head of heresy;

${ }^{108}$ Plato, 3:240.

109 Plato, 3:211.

${ }^{110}$ Plato, 2:490. This remark, in Grote's analysis, applied to the Politicus, but I think it relevant to the Republic as well. Cf. Grote's remark in BL Add. MS 29,521, fo. 16 .

111 Plato, 3:460.

${ }^{112}$ Plato, 3:409-10. 
Aristotle and Epikurus under the second; Herodotus and Nikias under the third. ${ }^{113}$

\section{APPENDIX A \\ German Platonism ${ }^{114}$}

Germany in the nineteenth century was dominated by a controversy about the order and authenticity of Plato's dialogues. ${ }^{115}$ Windelband defined the two major theories that prevailed, as the Systematic and the Historical. ${ }^{116}$ The first was represented by the Platonis restitutor Schleiermacher, as called by Christian Brandis. ${ }^{117}$ Schleiermacher's leading hypothesis was the systematic interdependence of Plato's dialogues: Plato had a preconceived philosophical scheme, to which he gave form throughout three symmetrical progressive stages of his activity as a writer. ${ }^{118}$ It was not accidental that the 'systematic school' started with Romanticism. Romanticists wanted to renew the philosophical aims and to reclaim the 'true' ends of politics. Plato was called to aid the movement. The past had to be idealized and

${ }^{113}$ Plato, 3:413. Socratic elenchus is in reality decried (3:304), and Socrates himself could not be allowed to exist there (3:242).

${ }^{114}$ As a point of departure I regard the work of W.G.Tennemann (System der Platonischen Philosophie, in 4 vol., Leipzig 1792-5), who first relied on Plato alone, and not on the Neo-Platonic interpreters, as to the meanings of his philosophy.

${ }^{115}$ See Hermann Bonitz's comments in his Platonische Studien (3rd ed.), Berlin 1886 , pp. v-vi.

${ }^{116}$ W.Windelband, History of Ancient Philosophy, London 1900, p. 181.

117 C.A.Brandis, "Plato", in W.Smith (ed.), Dictionary of Greek and Roman Biography and Mythology, London 1859, vol. III, p. 395.

118 Each transition was supposed to prepare the next one, Introduction to the Dialogues of Plato, Oxford 1836, especially pp. 45-6. 
viewed as a perfect harmony. An harmonious Platonic system, it was conceived, was that which obeyed the standards of logical relations, and avoided conceptual incompatibilities. The Historical school, represented mainly by Hermann, and, within limits, by Ast, held that Plato's philosophy fell short of a well-planned structure. Karl Friedrich Hermann asserted that Plato's affirmative philosophy, as distinguished from the Socratic, ${ }^{119}$ was acquired gradually throughout his life, and reflected the enlargement of his philosophic horizon. ${ }^{120}$ Friedrich Ast, best known as the author of the industrious Lexicon Platonicum, ${ }^{121}$ could be regarded, together with Hermann, as one of the most vigorous adversaries of Schleiermacher. Ast argued that the Platonic dialogues were not internally connected, nor progressively arranged. ${ }^{122}$ Ast's hypothesis, was not strictly historical, like Hermann's, but aesthetic. Plato sought above all aesthetic perfection. ${ }^{123}$ In Ast's view Plato did not confine his creativity within the narrow limits of systematic thought; on the contrary, his objects were many-sided, and his role was sometimes that of a poet, or an artist, and other times that of a philosopher. In Plato the ideal was joined with the actual, the mythic with

119 See, Gomperz, Greek Thinkers, vol. II, p. 288: Hermann believed in the existence of a purely Socratic period.

${ }^{120}$ K.F.Hermann, Geschichte und System der Platonischen Philosophie, Heidelberg 1839, pp. 368-98. Hermann was known in England mainly through his translated work, A Manual of the Political Antiquities of Greece historically considered, Oxford 1836, which was a detailed exposition of the development of political institutions in ancient Greece.

${ }^{121}$ Lexicon Platonicum, in 3 vol., Lipsiae 1835-8. Ast was also the editor of the Platonic Dialogues, in 9 vol., Lipsiae 1819-27.

${ }^{122}$ F.Ast, Platons Leben und Schriften, Leipzig 1816, p. 40.

${ }^{123}$ See Lutoslawski, The Origin and Growth of Plato's Logic, p. 49. 
the dialectical. Science and philosophy were bound up with religion. Platonism, according to Ast,

cannot be regarded as a system ... [O]ne finds in Platonism the germ of all systems without itself being the foundation of any; for it is the idea of philosophy, the focus of its particular forms, the immovable sun of its planetary changes. Platonism is idealistic, without being itself apparently idealism; it is realistic, without being realism. ${ }^{124}$

Each composition, in Ast's judgment, was in itself a self-contained whole, not necessarily connected with the remaining dialogues. For Plato's principal aim was to generate in the minds of his hearers the impulse of exhaustive research, and not to nourish their intellects with a stringent dogmatism. Someone could suppose that Ast's treatment of Plato was an anticipation of Grote's. ${ }^{125}$ They, however, coincided only in their general point of view. For Ast proved inconsistent, and whereas his theoretical standpoint did not logically allow the rejection, on the grounds of internal reasons, of any Platonic composition, he came to reject a great number. ${ }^{126}$

Schleiermacher and Hermann established two different approaches to Plato, which were adopted with variations by other scholars. The scholars who had accepted Schleiermacher's pattern came consequently to disallow many compositions as spurious. The other group also followed the same line, as far as rejection was concerned. The systematic school rejected some works mainly because they were

${ }^{124}$ (Ibid., pp. 4-5). The translated text is quoted from B.B.Edwards and E.A.Park, Selections, New York 1839, p. 380.

${ }^{125}$ Grote, in fact, recognised that Ast's "general view" coincided more nearly with his own than that of any other critic (Plato, 1:174n.f).

${ }^{126}$ Windelband followed closely Ast's steps in arguing that "the dialogues are not scientific treatises, but works of art". Like Ast he proceeded inconsistently to reject thirteen dialogues which "are certainly not genuine" (History of Ancient Philosophy, pp. 179-181). 
supposed not to fix the progressive requirements of Plato's scientific ends. ${ }^{127}$ The historical school, assumed that some dialogues were inferior to the rest in matter and execution, and were thus disallowed. ${ }^{128}$

Zeller, Ritter and Brandis, accepted, in the main, the theory of Schleiermacher, though each of them had developed different general schemes respecting the authenticity of the dialogues. ${ }^{129}$ Ast was in substance followed by Bonitz, who argued that Plato's affirmative aspect of philosophy had been overestimated. Many of the doctrines ascribed to him were never clearly proclaimed in his dialogues. Nor was a systematic unity to be found, as a result of each dialogue having in itself a purposeful individuality, usually related to Plato's design: namely, to cultivate the negative process of investigation. ${ }^{130}$ Similarly Strumpell did not see the likelihood

${ }^{127}$ As Paul Friedlander stated, Schleiermacher rejected several dialogues because they "did not link up with any other work of the master" (Plato, New York 1964, p. 127).

${ }^{128}$ The minor dialogues, were usually treated as of trivial, if any, philosophic significance. Grote reversed the judgement. Hermann rejected as spurious the Theages, Alcib.II and Epinomis (Geschichte und System der Platonischen Philosophie, Heidelberg 1839, pp. 413-31). Ast, except the Laws, he rejected also the Meno, Apology, Crito, Euthydemus, Laches, Charmides, Lysis (Platons Leben und Schriften, pp. 376-85).

${ }^{129}$ Ritter detected, like Schleiermacher, three periods in Plato's philosophy, History of Ancient Philosophy, vol. II, pp. 184-7. He rejected on the ground of spuriousness the Theages, Hippias Major, Epistles, Epinomis, Alcib.II, Hipparchus, Minos (pp. 162-5). Zeller rejected the Laws, Platonische Studien, Tubingen 1839, pp. 1-131 (the Laws were rejected also by Ast, Leben und Schriften, p. 384; G.F.W.Suckow, Die Wissenschaftliche und Kunstlerische Form der Platonischen Schriften, Berlin 1855, p. 414; and, Ackermann, The Christian Element in Plato, p. 31.). A contemporary of Schleiermacher, J.Socher, rejected the Politicus, Parmenides, Sophist, Charmides, and the Critias, Ueber Platons Schriften, Munchen 1820, pp. 26291.

${ }^{130}$ H.Bonitz, Platonische Studien, Wien 1858, pp. 5, 8-9, 74-6. 
of determining by means of a minute examination of the scanty evidence the order (if such order existed in Plato's mind) of the Platonic compositions. ${ }^{131}$

Later German scholars, like Ueberweg, tried to reconcile the theories of Schleiermacher and his opponents, asserting that Plato did not frame a philosophic system early in his life, but in a period subsequent to his visit to Megara. ${ }^{132}$ Thus it is vain, in his view, to search for a preconceived scheme pervading his earlier compositions. ${ }^{133}$

In conclusion, German Platonists presupposed, at least, a certain essential character pervading Platonic philosophy, despite their disagreement over the arrangement and order of the various dialogues. Their practice to discard individual compositions betrayed their preestablished idea of Plato's potential, as well as their propensity to assume an overall purpose (strictly philosophic or aesthetic) in his writings. In effect, all had practically conceded to the idea of a set of features present in Platonic philosophy. Their controversy was basically related to the degree of systematic form they were willing to bestow to those features.

131 Ludwig Heinrich Strumpell, Geschichte der Praktischen Philosophie der Griechen vor Aristoteles, Leipzig 1861, pp. 293-5.

${ }^{132}$ F.Ueberweg, Untersuchungen uber die Echtheit und Zeitfolge Platonischen Schriften, und uber die Hauptmomente aus Plato's Leben, Wien 1861, especially pp. 108-112. Ueberweg, however, doubted the authenticity of the Parmenides, Sophist and Politicus; see W.Lutoslawski, Origin and Growth of Plato's Logic, p. 56. Windelband also rejected a number of minor dialogues and he regarded doubtful the same dialogues as Ueberweg. See History, p. 181.

${ }^{133}$ It should be noted here that the great majority of scholars took for granted that Plato had written dialogues when very young, and when Socrates was still alive. Grote criticized their assumption, and argued that Plato did not compose any work before Socrates' death. 
Their works contributed significantly to the advancement of Platonic studies in Western Europe. Their critical disposition had the positive effect of advancing towards a more scientific and more rational interpretation. Their position, with respect to Grote, was both positive and negative. Positive, in the sense that, if we are to trace some influences in the field of classical scholarship upon Grote's thought, we should resort to German historians and classicists. Negative, in the sense that, the dogmatic superstructure they erected, together with their scepticism as to the importance and authenticity of many minor dialogues, were, for Grote, an extra incentive to look for answers relied on reason and evidence alone.

\section{APPENDIX B}

\section{The Authenticity of the Corpus Platonicum}

The controversy over the authenticity of some Platonic dialogues originated, for reasons which have been shown above, in nineteenth-century Germany, ${ }^{134}$ and has survived until the present day. In antiquity, according to Diogenes Laertius, there was an unanimous agreement as to which of the Platonic dialogues were genuine and which were spurious. ${ }^{135}$ Grote examined the historical circumstances and concluded

${ }^{134}$ Indeed the authenticity of some of them had been doubted in antiquity, e.g., the Hipparchus by Aelian (Various History, VIII.1-2). Diogenes Laertius states that "some say that Philippus of Opus .. was the author of the Epinomis" (III.37). Panaetius, the Stoic philosopher, rejected the Phaedo as not worthy of Plato's stature (Grote, Plato, 1:157). Further Proclus doubted the authenticity of the Republic and the Laws (Olympiod. Proleg. c.26, quoted in Paul Shorey, What Plato Said, Chicago and London 1933, p. 452).

135 See Diog.Laer., III.62: "The following dialogues are acknowledged [omologoumenos - a word that denotes the existence of common consent] to be spurious." Some of them were the Eryxias, Sisyphus, Axiochus, Demodocus, Definitions, etc. That the ancients took a great interest in classifying and ordering the Platonic works is shown by the writer of the Anonymous Prolegomena to Platonic 
that there was a strong presumption in favour of the authenticity of the catalogue transmitted from antiquity, i.e., the classification of Thrasyllus. Thrasyllus was the astronomer of Emperor Tiberius, who reigned from 14 to 37 A.D.

Diogenes Laertius (III. 57-61) enumerated the nine Trasyllian tetralogies of the Corpus Platonicum. The nine tetralogies are as listed below: (1) Euthyphro, Apology, Crito, Phaedo; (2) Cratylus, Theaetetus, Sophist, Politicus; (3) Parmenides, Philebus, Symposium, Phaedrus; (4) Alcibiades I and II, Hipparchus, Rivals; (5) Theages, Charmides, Laches, Lysis; (6) Euthydemus, Protagoras, Gorgias, Meno; (7) Hippias Major, Hippias Minor, Ion, Menexenus; (8) Cleitophon, Republic, Timaeus, Critias; (9) Minos, Laws, Epinomis, Epistles. As Chroust remarks the distribution of the thirtysix dialogues ascribed to Plato among the nine tetralogies was based on their dramatic treatment. ${ }^{136}$ Nevertheless, the philosophical validity and thematical coherence of the first tetralogy is incontestable. Dunn went further, and defended the internal coherence of all the tetralogies, as contrasted with the partial divisions of the Platonic Corpus by the Neo-Platonists. ${ }^{137}$ Grote, of course, was not interested in discovering any internal coherence in Plato's works. But he was the first who emphasized the

Philosophy (ed. L.G.Westerink, Amsterdam 1962), ch. X.

136 A-H.Chroust, "The Organization of the Corpus Platonicum in Antiquity", Hermes, 93(1965):41. See also R.G.Hoerber, "Thrasyllus' Platonic Canon and the Double Titles", Phronesis, 2(1956):13.

137 M.Dunn, "Iamblichus, Thrasyllus, and the Reading Order of the Platonic Dialogues", in R.B.Harris (ed.), The significance of Neo-Platonism, New York 1976, pp. 59-80. The Neoplatonists were eclectic in their treatment of Plato's works. Plotinus had revealed his preference for a few dialogues only; see R.F.Hathaway, "The Neoplatonic Interpretation of Plato: Remarks on its Decisive Characteristics", Journal of the History of Philosophy, 7(1969):20-22. 
importance of Thrasyllus' classification, as indicating the works that were unanimously accepted as authentic in antiquity. ${ }^{138}$

Grote concluded that all available evidence showed that Thrasyllus came to classify the dialogues in accordance with the divisions made by Alexandrian scholars and grammarians. Grote claimed that Plato's manuscripts (finished dialogues, unfinished fragments, or preparatory sketches), had been preserved in the Academy as sacred memorials. ${ }^{139}$ The scholars of Alexandria were trustworthy authorities since they had in their possession the entire Corpus, transmitted to Alexandria by Demetrius of Phalerum. Demetrius was the agent of Ptolemy Soter who generally favoured the philosophers at Athens. He was also contemporary of the Scholarchs of the Academy, who succeeded Plato immediately after his death. Demetrius paid experts to make exact copies of the Corpus, which had been preserved in the library of the Academy.$^{140}$ It was very likely that soon after Plato's death an authoritative academic edition of his collected works was brought to light by his most eminent pupils. ${ }^{141}$

${ }^{138}$ Grote disagreed with Thrasyllus as to which dialogues belonged to the Expository and which to the Searching group. See Plato, 1:235.

${ }^{139}$ Plato, 1:134-5. On the question of book-collection in the fourth century B.C. see, E.G.Turner, Athenian Books in the fifth and fourth centuries B.C. (An Inaugural Lecture delivered at University College London), London 1952. E.A.Parsons gives an account of the early Greek book-collectors in The Alexandrian Library, London 1952, p. 8.

${ }^{140}$ Plato, 1:134-6, 146.

${ }^{141}$ Aristotle's works on the other hand, in lieu of such an authoritative edition, suffered considerable mutilation. On the story concerning the Aristotelian Corpus, see Diog.Laert. (V.52) and more precisely by Strabo (Geography, XIII.608-9). Thus the Aristotelian testimony as a criterion of Platonic authenticity is, as Gomperz remarked, objectively inadequate. See Greek Thinkers, vol. II, p. 278. 
Grote's assumption of an 'Academy edition' which was probably the work of the first generation of Plato's pupils, was accepted by many scholars. Pfeiffer believes that Plato's pupils collected, arranged, and copied his autographs: this edition "became the basis of all the later ones", ${ }^{142}$ i.e. of the Alexandrine editions, possibly of the editions published in Pergamum by the philosophers of the Pergamine library, ${ }^{143}$ and of the Derkyllidean and Thrasyllian editions. Philip argues that we must not overlook the hypothesis that "the Academy preserved an authoritative text of a corpus formed soon after Plato's death". ${ }^{144}$ Only this hypothesis may give an explanation to the fact that the text of Plato has been so much better transmitted than the texts of Aristotle or the historians. Similarly Solmsen maintains that "the tendency is to revert to the idea of a standard edition issued by the Academy, at a time not too distant from Plato's death". ${ }^{145}$

Grote's contemporary scholars rejected his arguments as too bold. ${ }^{146}$ Campbell, for instance, blamed him for introducing an unorthodox principle, namely

${ }^{142}$ R.Pfeiffer, History of Classical Scholarship, Oxford 1968, pp. 65-6.

${ }^{143}$ The king of Pergamum, Eumenes I (263-241 B.C.) showed a special interest in the Academy. See Sandys, A History of Classical Scholarship, Cambridge 1903, p. 149. The local library had its own Pinakes of authors and their works, which merited praise, "even in comparison with the famous Pinakes of Callimachus" (Parsons, Alexandrian Library, p. 29).

${ }^{144}$ J.A.Philip, "The Platonic Corpus", Phoenix, 24(1970):306.

${ }^{145}$ F.Solmsen, "The Academic and Alexandrian Editions of Plato's works", Illinois Classical Studies, 6(1981):102.

${ }^{146}$ In his article on "The authenticity of the works of Plato", Fortnightly Review, 2(1867):283, W.L.Blackley sided with the German Schaarshmidt (Die Sammlung der Platonischen Schriften, Bonn 1866), who rejected the Parm., Polit., and the Sophist as spurious. 
that there was no limit to the differences of matter, manner, or of merit in Plato. ${ }^{147}$ The external evidence was inseparable from the internal, and the combination of both pieces of evidence should be accepted in so far as the external evidence invoked by Grote, left room for unanswered doubts. How could we be sure that Plato's successors in the Academy, Xenocrates and Speucippus, did not compose dialogues that were handed down to posterity as among those of Plato's? ${ }^{148}$ A German, Heidel, published a studious work on the pseudo-Platonic dialogues, being clearly influenced by the recent German tradition. ${ }^{149}$

Others were content to agree with Grote. The belief that the entire Corpus was authentic sometimes went together with the assertion that there is no point in excluding any dialogue since all were self-contradictory. ${ }^{150}$ But sometimes this belief was grounded on more moderate and reasonable ideas. ${ }^{151}$

Grote offered a great service in maintaining the authenticity of all Platonic works. First, he made it difficult for scholars after him to reject whole-heartedly two thirds of Plato's compositions as not answering their own intellectual demands. Secondly he pointed out the many-sided character of Plato's dialogues, which allowed

${ }^{147}$ Campbell, "Grote's Plato", Quarterly Review, 119(1866):144. A.W.Benn argued that the authority of the canon is much weaker than Grote thought. See "Plato and his Times", Westminster Review, 114(1880):392.

${ }^{148}$ Further, Jowett asked: "Would Mr.Grote accept as genuine all the writings which he finds in the lists of learned ancients attributed to Hippocrates, to Xenophon, to Aristotle?" (The Dialogues of Plato, Oxford 1892, vol.I, p. xii).

${ }^{149}$ W.A.Heidel, Pseudo-Platonica, Baltimore 1896.

${ }^{150}$ G.H.Lewes, "Mr.Grote's Plato", Fortnightly Review, 2(1865):178-9. See also J.R.Thursfield, "Mr. Grote's Plato", Westminster Review, 84(1865):465.

${ }^{151}$ See Gomperz, Greek Thinkers, vol. II, p.277; Herbert Richards, Platonica, London 1911, pp. 285-6. 
for considerable differences between one dialogue and another. The tendency in our own times is rather averse to rejecting Platonic compositions, except those that were in antiquity commonly disallowed. ${ }^{152}$ But scholars still attempt to divide the dialogues between those of a Socratic (early), middle, and mature periods of Plato's life. Yet, Grote never denied that there were such Platonic periods: he only deemed it extremely difficult to identify them with historical accuracy.

${ }^{152}$ Guthrie makes a direct reference to the name of Grote, and argues that it is not right to dismiss dialogues as mere imitations, depending on repetitions of matter or phraseology, especially in the case of Plato, who repeats himself so often. See History of Greek Philosophy, vol. V, p. 383. Recently T.L.Pangle acknowledged the contribution of Grote in promoting the re-examination of the Corpus. Grote, states Pangle, "defended the authenticity of the entire canonical listing with a strictly historical argument that seems to us to merit the most serious attention" (The Roots of Political Philosophy. Ten Forgotten Socratic Dialogues, Ithaca and London 1987, p. 6). 


\section{Chapter 7}

\section{THE SOPHISTS AND SOCRATES REVISITED}

\section{The Sophistic Enlightenment}

The uncommonly favourable judgement Grote passed on the sophistic movement, first in his famous 67th chapter of his History, appeared to the majority of his contemporaries as having the air of a paradox. The sophists occupied no very high place in the world's esteem until Grote set about to question the traditional verdict which identified them with immoral travellers, who conveyed their spurious wisdom by employing seductive reasoning. ${ }^{1}$ Mitchell had characteristically described his undertaking to give an account of the sophists as a

melancholy task ... to follow this pestilent race into their dark recesses, and to point out by what means they endeavoured to effect that dislocation and looseness in the moral frame, which their infamous doctrines caused among the men of Greece. ${ }^{2}$

The traditional verdict was shaped, in Grote's judgement, mainly by Plato's ${ }^{3}$

\footnotetext{
${ }^{1}$ See a general outline of the sophists' treatment before Grote in Alexander Grant (ed.), Lectures on Greek Philosophy and other Philosophical Remains of James Frederick Ferrier, Edinburgh and London 1866, vol. I, p. 189.

${ }^{2}$ T.Mitchell, "Panegyrical Oratory of Greece", Quarterly Review, 27(1822):385, emphasis added. See also W.G.Tennemann, A Manual of the History of Philosophy (part of his Geschichte der Philosophie, Leipzig 1798-1819), London 1852, p. 82; F.Schlegel, Lectures on the History of Literature, Edinburgh 1818, vol. I, p. 62; H.Ritter, History of Ancient Philosophy, Oxford 1838, vol. I, p. 531. Joseph Socher, however, had recognised that Plato brought disgrace upon an honourable name. See Ueber Platons Schriften, Munchen 1820, p. 11.

${ }^{3}$ Without having seen or ascertained anything about the sophists, Anytus in the Meno "hates them as violently as if he had sustained from them some personal injury: a sentiment which many Platonic critics and many historians of philosophy have inherited from him" (Plato, 2:27).
} 
understanding of the role of these men in the field of education, and the close connection of sophistic principles with public affairs by means of the art of rhetoric. On the basis of Plato's testimony, according to Grote, it is difficult to conceive of how the sophists could ever have acquired any acceptance among their contemporaries. In the Euthydemus Plato represented the art of the sophists "so incredibly frivolous", as if it aimed solely at drawing "a person into absurd and contradictory concessions".4 It is very important to remember, Grote believed, that it was Plato who dissented from the principles of established morality and contemporary politics. ${ }^{5}$ His reformatory and theorizing inclination brought him into polemical controversy with all the leading agents by whom the business of practical life at Athens was carried on. ${ }^{6}$ Consequently, the ethical precepts of his times did not escape his severe criticism: the sophists, in Grote's view, followed the norms of their epoch, accepting current ethical and political sentiments. Plato was the dissenter, who attacked the sophists, as he attacked the politicians of his times, not as a particular sect, but as one of the existing orders of society. But another reason, equally significant, which gave birth to that deplorable animosity against the sophists, was the historians' tendency to accentuate Plato's hostility to them. Plato was definitely ill-disposed towards the real purpose of their teaching: to teach the art of words meant for him to enable undeserving persons to reach distinction by means of flattery and deception. But Plato knew very well that the sophistic curriculum was not confined to rhetoric. Further, Plato appears to have

\footnotetext{
${ }^{4}$ Univ. of London Library, MSS 429/3 (1817), fo. 138.

${ }^{5} \mathrm{His}$ "quarrel is not less with the statesmen, past as well as present, than with the paid teachers of Athens" (History of Greece, London 1888, 7:38; see also p. 75).

${ }^{6}$ History, 7:39.
} 
respected eminent sophists, like Protagoras. He nowhere ascribed to him corruption or incompetence. ${ }^{7}$ Grote believed that even Plato's testimony, "when construed candidly and taken as a whole, will not be found to justify the charges of corrupt and immoral teaching". ${ }^{8}$ Plato was thus unjustly considered as passing indiscriminate condemnation of the whole movement. Grote believed that when scholars cited primarily Plato as the source on which they based their harsh criticisms of sophistic thought, they were unjust towards the ancient philosopher. Grote conceived himself here as defending Plato against the notion that he grossly and dishonestly misrepresented the whole sophistic movement. "I am happy", he wrote, "to be able to vindicate Plato against the disgrace of so dishonest a spirit of argumentation" which has been ascribed to him. ${ }^{9}$

(i) In Defence of the Sophists

Grote's defence of ancient sophistike is focussed on the following propositions:

(a) The sophists were never a separate class, nor a school with common dogmas, principles or methods. ${ }^{10}$ There was never such a thing as 'die Sophistik', as

${ }^{7}$ Plato and the other Companions of Socrates, London 1865, 2:34-35-36n; History, 7:59. Similarly Tennemann maintained that Plato's "liberal mode of thinking" led him to allow justice to the sophists' talents and services ("Life of Plato", trans. from the System der Platonischen Philosophie, Leipzig 1792-5, in B.B.Edwards and E.A.Park, Selections from German Literature, New York 1839, pp. 361-2).

${ }^{8}$ History, 7:43, 59.

${ }^{9}$ History, 7:62n.1, emphasis added.

${ }^{10}$ History, 7:53. Plato, 1:542, 2:114, 3:145. 
German writers had put it. ${ }^{11}$ Those who were designated by the common name were generally dissimilar in their principles and pursuits. ${ }^{12}$

(b) The opprobrious connotation of the word 'sophist' had been invented by Plato. ${ }^{13}$ In ancient Greece the epithet 'sophistes' was only a synonym for the wise man. Poets, priests, musicians, philosophers - all equally deserved that characterization. ${ }^{14}$

(c) If such a 'class' of men had ever existed in the way represented in the traditional account, it would have been hardly possible to survive anywhere. To say that the sophists defended arguments which were only probable in appearance, as Aristotle did, ${ }^{15}$ is to say that the persons who heard them teach were completely incapable of discriminating between true and false: "Of individuals, the varieties are innumerable: but no professional body of men ever acquired gain or celebrity by maintaining theses, and employing arguments, which every one could easily detect as false." ${ }^{16}$ Grote appears to have contested the idea of sophistic scepticism. For the

11 Plato, 1:260n. See, for instance, K.O.Muller, A History of the Literature of Ancient Greece, London 1858, vol. II, pp. 93-4.

${ }^{12}$ Henry Sidgwick who warmly took up Grote's point, went on to argue that the sophists did not even establish a similar philosophic tendency. See "The Sophists", Journal of Philology, 5(1873):66.

${ }^{13}$ Plato dealt with the meaning of this word in the Sophist 231d2-e6. For his definition of the sophist see also Protagoras 317b. Further, see Xenophon, Memorabilia, I.vi.13; Plutarch, Them. II.6.

${ }^{14}$ Plato, 2:35. See a similar argument in H.O.Rankin, Sophists, Socratics and Cynics, London 1983, p. 14.

${ }^{15}$ See Aristotle, Soph.El., I,165a21 and Rhet., II.xxiv., (1402a.23).

${ }^{16}$ Plato, 1:543. See also, G.H.Lewes Biographical History of Philosophy, London 1845, vol. I, pp. 159-60. 
sophists were the regular teachers of Greece, who adhered to established moral sentiment. But he would acknowledge that there was a kind of scepticism in their thought; yet, it was, in a wider sense, a scepticism which reflected the revolutionizing tendencies of the age, both in science (man becoming the centre of speculation), and in politics (demand for participation in government). Old values were subjected to the sceptical scrutiny of man's critical power. ${ }^{17}$

(d) The sophists, Grote continued, should be seen in the historical context of ancient democracy, as an offspring of their age. ${ }^{18}$ The sophists were not men to whom any corrupt purpose, or an immoral character can be imputed. They should be treated as the product of their fruitful age, men who heartily accepted the current ethical and political sentiment. ${ }^{19}$ On the other hand, to depreciate the sophistic contribution means in effect to undervalue ancient philosophic thought. Philosophy in Pericles' age was characterized by a negative spirit, and negative speculation was the point of departure of great philosophic movements. ${ }^{20}$ Sophistic research often did not procure positive results; rather, it tended, like Plato's negative compositions, to

${ }^{17}$ On the contrary A.Boeckh accused the sophists of assailing philosophy with their scepticism. See manuscript notes from his lectures, in B.B.Edwards and E.A.Park, Selections from German Literature, New York 1839, p. 382. See, also, H.Ritter, History of Ancient Philosophy, Oxford 1838, vol. I, p. 531. J.E.Erdmann, History of Philosophy, London and New York 1893, vol. I, pp. 78, 80-81, 83, 85.

${ }^{18}$ See also Lewes, Biographical History of Philosophy, vol. I, p. 179.

${ }^{19}$ Plato, 1:542-4, 2:432.

${ }^{20}$ Plato, 2:432. In V.Cousin's work sophistic thought had already regained some of its primary importance. See Introduction to the History of Philosophy, Boston 1832, p. 54. W.Sewell implicitly attacked Cousin, when he argued that in France, "that unhappy country", "the supposed sceptical and eclectical character of Platonism appears chiefly to have excited attention" (Introduction to the Dialogues of Plato, Oxford 1841, p. 3, emphasis added). 
strengthen the intellect and arouse scientific curiosity. The historians of philosophy, in Grote's judgement, were inclined to disregard the importance of negative analysis, which introduced man and society to the domain of philosophy as 'reasoned truth'.

(e) Further, Grote argued that the distinction drawn between the sophist and the dialectician could not be sustained. Both dialectic (in Plato) and ancient sophistike led to no truth: Plato obtained nothing more than a semblance of knowledge in the Timaeus. ${ }^{22}$ Though Plato in the Gorgias was at pains to condemn rhetoric, in the Crito he was himself an admirably skilful rhetor. ${ }^{23}$ As a dialectician, Grote maintained, Plato never met the demands of Socratic cross-examination, nor in reality could any man do so. Plato's "didactic theories deserve admiration", Grote believed, but, in accordance with the requirements of Socratic method, they marked out an ideal which was hardly attainable. ${ }^{24}$

(f) A main charge against the sophists, and often repeated by modern scholars, Grote went on, was that they received fees for their services. To ask or receive a fee for communicating knowledge and aptitude in debate was, in the judgement of Socrates and Plato, "a grave enormity: a kind of simoniacal practice". ${ }^{25}$ For Grote

${ }^{21}$ Plato, 1:260n and 3:485. G.H.Lewes similarly argued that negative analysis was preparatory and essential to the positive foundation of inductive inquiry. See The History of Philosophy from Thales to Comte, London 1871, vol. I, p. 233.

${ }^{22}$ Plato, 2:432; Plato, like the sophists, professed to be an encyclopedist: but "this was an error natural to the age".

${ }^{23}$ Plato, 1:305.

${ }^{24}$ Plato, 2:258.

${ }^{25}$ Plato, 2:430; also, History, 7:34. Plato attacked the sophists for asking and receiving fees especially in the Sophist, 231d and Hippias Major, 282d. 
there was nothing contemptible in this practice. ${ }^{26}$ At any rate the same accusation can be equally addressed to Plato himself who, though he undoubtedly never asked for fees, "received presents from rich admirers like Dion and Dionysius: and there were various teachers who found presents more lucrative than fees". ${ }^{27}$

(g) The most important aspect of Grote's defence, however, has been the reassessment of sophistic thought and activity, examined historically in relation to ancient democracy. The sophists, Grote maintained, were the practical teachers of their age, who never dissented from established morality. ${ }^{28}$ Protagoras in his pragmatic speech (to be found in the Platonic dialogue entitled after his name) made clear that he abided by common social standards, and that he only desired to teach people how to think, speak, and act, within the established democratic framework. The sophists were primarily engaged in supplementing the deficiencies of ordinary education in variety of subjects and in training men to participate in civic life. In teaching someone the art of persuasion, "they could not but make him feel the dependence in which he stood towards those who were to be persuaded". ${ }^{29}$ Therefore, their teaching aided materially the democratic life of Athens by strengthening individual thinking and cultivating the citizens' moral responsibility towards others. Plato opposed the 'art of persuasion', since he was deeply averse to popular government, where a citizen could

${ }^{26}$ See, however, J.Forster's historical justification of Plato's opposition to their practice of receiving fees, in "Socrates and the Sophists of Athens", Foreign Quarterly Review, 30(1843):342.

${ }^{27}$ Plato, 2:430n.b. On this see Plutarch, Aristides, I.3; similarly Sidgwick, Lectures on the Philosophy of Kant, London 1905, p. 345.

${ }^{28}$ See Protagoras, 328b.

${ }^{29}$ History, 7:79. 
freely express his view and encounter the opposition of others. The prevalence of this art, in Grote's judgement, "together with the strictness of the laws of debate, seem naturally to have arisen in a city where there was much freedom of thought and speech"..$^{30}$ According to Grote, Plato's censure of the sophists could be justified, provided that we accept, in harmony with his feelings, that "the social and political life of the Athenians was a dirty and corrupt business" ${ }^{31}$ Grote apparently believed that the sophists, like the demagogues, contributed to the development of Athenian democracy and to democratic consciousness in general. ${ }^{32}$ The sophistic training should be firmly connected with the idea of freedom and democracy in ancient Greece.$^{33}$ Further, the sophists appealed to Grote in so far as their teaching promoted a more extensive education. ${ }^{34}$

(h) Another aspect of Grote's defence of the sophists, which will be examined later, refers to his avowed belief that these men, as well as the Socratics after them,

${ }^{30}$ Univ. of London Library, MSS 429/3 (1817), fo. 140.

${ }^{31}$ Plato, 2:254. See also Grote's objection to Plato's arguments against rhetoric, in Univ. of London Library, MSS 429/3 (1817), fo. 146.

${ }^{32}$ History, 7:56-7. Cf. Schleiermacher, Introductions to the Dialogues of Plato, Cambridge 1836, p. 94. The sophistic sect, he argued, endowed with profound antiintellectualism, perverse immoral dispositions and lack of firm principles, was conducive to the decay of late fifth-century Athenian democracy,

${ }^{33}$ See Univ. of London Library, MSS 429/3 (1817), fo. 142; History, 7:41-2n. See what Plato puts into the mouth of Protarchus in the Philebus, 58a-b.

${ }^{34}$ History, 7:80. Universal education was a firm utilitarian motto. See BL Add. MS 29,528 (1818-1822), fo. 22. It is important to record J.V.Muir's thesis, namely, that Protagoras, who was appointed by Pericles to make laws for the Athenian colony at Thurii in 444 B.C. (Diog.Laertius, IX,50), enacted a law which provided basic education for all at public expense. See "Protagoras and Education at Thourioi", Greece and Rome, 29(1982):20. 
were closer to Socrates than Plato. ${ }^{35}$

The most distinguishing aspect of Grote's defence of the sophists was the part related to Protagoras. Grote brought to light the political and philosophical implications of the Protagorean 'man-measure' doctrine and appraised the significance of Protagoras' well known myth.

\section{(ii) Assessment of Protagorean Philosophy}

Grote was the first to consider the value of Protagoras' thought. He first focussed his attention on the Homo Mensura doctrine, ${ }^{36}$ arguing that Plato misrepresented it, perhaps not willingly, in the Theaetetus. Protagoras' philosophy, in Grote's thought, far from supporting moral egoism (i.e. Plato's fault in his constructive works), tended to emphasize the relativity of knowledge, and thus to abhor the idea of a 'Great Expert'. The famous myth was an account of reciprocal relations among fellow-citizens.

Grote criticized Plato's interpretation of the H.M. doctrine in the Theaetetus, namely, that it resulted in the identification of knowledge with sensible perception. Yet, the Protagorean doctrine did not impose such a limitation. ${ }^{37}$ Protagoras, according to Grote, affirmed that "every object known must be relative to (or in his language, measured by) the knowing Subject: that every cognitum must have its

${ }^{35}$ Plato, 3:505.

${ }^{36}$ Thereafter H.M.

${ }^{37}$ See the statement of Sextus Emp. (Against the Logicians, I.60), which may be taken as showing that the H.M. was not confined to sensible perception: "dia to pan to phanen he doxan", etc. 
cognoscens, and every cognoscibile its cognitionis capax" ${ }^{38}$ Having in mind that the H.M. doctrine was designed to establish the principle of relativism, perception as well as conception were to be accounted as functions of a Subject towards an Object. ${ }^{39}$ Thus, the H.M. doctrine was made to lay hold of the whole region of human understanding. ${ }^{40}$ Sensible perception as the fountain of knowledge (as Protagoras' critics assumed to have been his premiss), did not exclude the function of rational conception, as a means of the formation of cognition. A person was the Subject conceiving or believing external objects; to the extent that he could not part company with himself altogether, no absolute truths could be maintained. ${ }^{41}$

The Protagorean doctrine, thus exhibited, entailed (following Grote's reasoning) at least five propositions, each one of equal importance in philosophical speculation and political life. First, it established the relativity of knowledge. It naturally followed, secondly, that the H.M. doctrine expressed a distinct scepticism towards the existence of universally valid truths. ${ }^{42}$ Thirdly, Protagoras' doctrine appeared to be consistent

${ }^{38}$ Plato, 2:325-6. The Protagorean doctrine was also defended by the Eleate in the Sophist (2:335).

39 "Still we must recollect that all such a priori Concepts, Intuitions, Beliefs, \&c., are summed up in the mind: and that thus each man's mind, with its peculiar endowments ... is still the measure or limit of his cognitions, acquired and acquirable" (Plato, 2:328-9).

${ }^{40}$ The H.M. doctrine proclaimed, in Grote's view, "the relativeness of all objects perceived, conceived, known, or felt" (Plato, 2:335-6).

${ }^{41}$ Plato, 2:334, 2:340-1 and 2:511.

${ }^{42}$ Grote himself admitted that no "infallible objective mark, no common measure, no canon of evidence, recognised by all, has yet been found. What is Truth to one man, is not truth, and is often Falsehood, to another" (Plato, 2:360). L.Campbell compared Protagoras and Hume: "both were content to rest within the clearly defined boundary of a 'certain uncertainty,' without even an aspiration after Absolute or Ideal Truth" ("Introduction" to Theatetus, Oxford 1861, p. lxxxiv). 
with the principle of toleration since it afforded room for "great diversities of knowledge, intellect, emotion, and character, between one man and another". ${ }^{43}$ The fundamental assumption of the Protagorean formula is "autonomy of each individual mind". Fourthly the H.M. doctrine, contrary to Plato's assertion that it demolished philosophic thinking, was the very basis upon which philosophy as 'reasoned truth' could stand. When Protagoras said that man is the measure of all things, he meant that "every opinion delivered by every man is true, to that man himself", and not, as Plato asserted, that every opinion of every man is true. ${ }^{44}$ Plato accused Protagoras of asserting, as a consequence of his premiss, that all men were equally wise. Grote's interpretation, of course, led him to reject Plato's assumption. ${ }^{45}$ Grote would have surmised with satisfaction that the H.M. doctrine, as a tool of philosophic investigation, embraced both sense (experience) as well as sentiment (individual belief and affection). ${ }^{46}$ Lastly, Plato, himself, never escaped from the region of the Relative and the Protagorean formula. He simply passed from "Mind Percipient to Mind

\footnotetext{
${ }^{43}$ Plato, 2:351.
}

${ }^{44}$ Plato, 2:347.

${ }^{45}$ Plato, 2:352. See the "apology of Protagoras", as given in the Theaetetus (166dseq.). That Protagoras acknowledged differences among individuals as far as intellectual and moral ability is concerned, is shown in his declaration in the dialogue which bears his name, that he believed himself a little superior to the rest in ability to teach virtue $(328 \mathrm{~b})$.

${ }^{46}$ In an essay on 'Metaphysical Truth', written in a true utilitarian spirit (BL Add. MS 29,528 (1818-22), fos. 1-8), Grote argued that the evidence of such truth should be sought in human action, and not in consciousness. This source is advantageous since: (a) human action is a fact evidenced, distinct and unequivocal; (b) such evidence, as deriving from human action is perfectly communicable; (c) human action is in reality fact subjected to the senses, i.e. it is sensation. Sensations "are far stronger and clearer than any other of the mental phenomena"; and (d) human action can be only observed, and observation leads to the recognition that pleasures and pains are what men seek to have or avoid. 
Cogitant". ${ }^{47}$

As shown above, Grote did not regard the theory of Utility, put forward by Socrates in the Protagoras, as the theory of modern utilitarianism, because it appeared to him morally egoistic. The Protagorean mythos, however, presented in the same dialogue, appealed more to Grote as an admirable account of the growth and propagation of common ethical and social sentiment. He confessed that the myth was to him "one of the most striking and instructive portions of the Platonic writings." In the 'myth' man's destiny was bound up with that of the community in which he lived. ${ }^{49}$ Protagoras' theory of justice (dike) and the sense of shame (aidos) was considered by Grote as equivalent to the idea of reciprocity (i.e. in Grote's words "reciprocal duty and right").

\section{II}

\section{Socrates the Sophist, and the Athenians}

"The death of Socrates, as it is usually conceived and commented upon by moderns, appears a case of atrocity almost incredible." Thus wrote Grote in an unpublished essay on 'The Character of Socrates' dated on Mrs Grote's testimony,

${ }^{47}$ Plato, 2:374n, 2:383n.h, 2:477. Plato used thoroughly the Protagorean formula in his dialogues; see Plato, 2:358.

${ }^{48}$ Plato, 2:45; "if I could believe that it was the composition of Protagoras himself, my estimation of him would be considerably raised" (Plato, 2:47n). politikon.

${ }^{49}$ It can be argued that Protagoras' myth defined, before Aristotle, man as a zoon

${ }^{50}$ Plato, 2:84. 
from 1825 or $1826 .^{51}$ Grote's uniqueness in his approach to Socrates consisted in his conception of him as a sophist; in his admiration of Socrates' negative dialectic; and in his justification of the Athenians for condemning him to death.

\section{(i) Socrates the Sophist}

Grote believed that by talking with small circles of listeners upon a variety of subjects, by not revealing his own sincere convictions, and by showing a constant inclination to enantiopoiologia and irony Socrates appeared to have been the most distinguished of the sophists. ${ }^{52}$ Socrates, Grote argued,

is a Sophist of the most genuine and noble stamp: others are Sophists, but of a more degenerate variety ... [A]ccording to the characteristic of the true Sophist here [i.e. in the Sophist] given by Plato, Protagoras and Prodikus were less of Sophists than Sokrates. ${ }^{53}$

In his sixth definition of the sophist (in the dialogue that bears this name) Plato stated that he cleared (katharsis) the soul from opinions which hindered (doxon empodion) the attainment of knowledge. This aspect of sophistike he called "gennaia sophistike", and in effect it could be fully identified with the socratic method. ${ }^{54}$ The Elenchus

${ }^{51}$ BL Add. MS 29,522, fo. 162 . I have already argued that this essay was an earlier composition written even prior to 1819. Grote's handwriting, as well as his style, are characteristic of youth. In this essay Grote had not called attention to the Socratic method of cross-examination, as he did in his subsequent works. It might have been James Mill's influence that prompted him in that direction. Supposing the essay to have been composed in 1825 or 1826 such omission would appear rather odd. Cf. M.L.Clarke, George Grote, London 1962, p. 135.

${ }^{52}$ Plato, 2:428. Socrates, in comparison with Protagoras, is decidedly the more Eristic of the two. See also 3:479: "A person more thoroughly Eristic than Sokrates never lived".

${ }^{53}$ Plato, 2:431; and History, 7:43-4.

${ }^{54}$ Plato, 2:430-1; see Sophist, 231d.e. 
ascribed to these teachers in the Sophist was peculiar to Socrates. Protagoras was not a sophist in this sense. Grote pointed out that "the definition which [Plato] at last brings out suits Sokrates himself, intellectually speaking, better than any one else whom we know".55 Irony and Eristic were the special weapons of Socrates in promoting his negative analysis. It was Socrates, Grote maintained, who applied negative analysis to common beliefs, and not the sophists as the German scholars believed. ${ }^{56}$ It was Socrates who employed 'sophistry' against the sophists. Historians "do not like to see Sokrates employing sophistry against the Sophists: that is, as they think, casting out devils by the help of Beelzebub". ${ }^{57}$ Historians accused the sophists of challenging every criterion of truth and morality, of applying their destructive scepticism everywhere, having nothing to offer as a substitute. Their assertion had its roots in their conception of a dogmatic Socrates - the supposed antagonist of the sophists. ${ }^{58}$ It appeared almost incredible to them that Plato's mentor had not developed positive doctrines. Grote protested against the oft-repeated assertion that

${ }^{55}$ History, 7:44.

${ }^{56}$ Plato, 1:260n.

${ }^{57}$ Plato, 1:395.

${ }^{58}$ German scholars, like their British contemporaries, concurred in regarding Socrates as the enemy of the sophists. Schlegel, in his effort to justify Aristophanes' attack on Socrates, argued that the poet had confounded the "inestimable Sage with his enemies the Sophists" (Lectures, vol. I, p. 62). See also G.F.Wiggers, "Life of Socrates" (originally, Sokrates als Mensch, Burger und Philosoph, Rostock 1807), in W.Smith (ed.) PLATO, London 1852, pp. xv-xvi; Tennemann, A Manual of the History of Philosophy, pp. 88-90. Ludwig Strumpell however, believed that Socrates was not especially hostile towards the sophists. See Die Geschichte der Praktischen Philosophie der Griechen vor Aristoteles, Leipzig 1861, p. 34. E.Zeller admitted that before Hegel and Grote there was a general agreement "in accepting Plato's view, and looking on Socrates as the opponent of the Sophists" (Socrates and the Socratic Schools, London 1885, p. 189). 
Socrates developed a positive philosophy, and claimed that even the word 'Socratic school' should be used only in the vaguest sense. ${ }^{59}$ Socrates was as ignorant as others; he was superior to them in so far as he was ultimately fully conscious of his own ignorance. ${ }^{60}$ Socrates did not arrive at any scientific results: his main purpose was to generate a painful consciousness of ignorance.

MacIlwraith confessed that it was "exceedingly difficult" for him to understand why Grote identified Socrates so closely with the sophists. ${ }^{61}$ Macllwraith, like many others, misunderstood Grote's argument. It would be wrong to say that Grote identified Socrates with the sophists. He characterized Socrates as a sophist in the light of the traditional conception of what a sophist was. If disputation and negative analysis were to be taken as clearly sophistic elements, then those who were designated ancient sophists, were, if at all, definitely lesser sophists than Socrates himself. When he stated that the word 'Sophistik', employed by Zeller and other Germans, should be replaced by the word 'Sokratik' ${ }^{32}$, he meant that the conception of sophistike, as the art of disputation, and negative results, suited Socrates perfectly. The traditional, narrow definition of the sophist, accepted almost unanimously in modern times (which largely differed from the idea of a sophist in literature before Plato who made the word a synonym for conceit and charlatan wisdom), rendered Socrates a representative sophist, whereas Protagoras, Gorgias and the others, could
${ }^{59}$ Plato, 3:472.
${ }^{60}$ Plato, 1:288.
${ }^{61}$ W.MacIlwraith, The Life and Writings of George Grote, London 1885, p. 28.
${ }^{62}$ Plato, 1:260n. 
not be understood as perfect sophists. Socrates differed from them ${ }^{63}$ both in not pretending to be able to answer any question, as well as in confessing that he disapproved of the democratic constitution of Athens. ${ }^{64}$ For Grote the points of coincidence are, however, strong enough and lie in two directions: first, in their use of conversational techniques (dialectic method) to arouse the interest of the pupil; and secondly, in their understanding of Virtue as a relative term. ${ }^{65}$ It is the second point of resemblance which warranted the argument that the sophists were nearer to Socrates as far as his teaching was concerned. "The religion of Sokrates, as well as his ethics, had reference to practical human ends. His mind had little of that transcendentalism which his scholar Plato exhibits in such abundance. ${ }^{166}$ Grote trusted Xenophon's

${ }^{63}$ It is worth noting that Grote in his unpublished essay on Socrates appears indeed to have contrasted Socrates with the sophists. See BL Add. MS 29,522, fo. 163: "The sympathy of the moderns is so preengaged in favour of Socrates, that they never consider what must have been the feelings of eminent sophists and rhetoricians, whom Socrates unmercifully encountered and exposed. These men, illustrious amidst the general public for their acuteness, eloquence and expository powers, found themselves inextricably ensnared by the cunning series of questions which he successively put to them ... Men of this unexampled eminence [like Protagoras and Gorgias], admired by all their contemporaries, must have been stung to the quick by the successful traps which Socrates laid for them in the dialogue: their admirers and the spectators, in all probability, shared their feelings, and exclaimed against the victories of Socrates as obtained by mere sophistical trickery. The tone of Socrates ... is altogether polemical and aggressive: he seeks purely and simply to wound and disarm an antagonist". Emphasis added. In the same spirit, see History, 7:132.

${ }^{64}$ See K.R.Popper, The Open Society and Its Enemies, London 1952, vol. I, p. 194: Socrates, though a critic of Athenian democracy, was not anti-democratic. Popper assumed that Grote's argument in favour of taking the Apology as an historical document was designed principally to disconnect Socrates' name from Plato's authoritarianism. I think Grote's argument was primarily intended to lay emphasis on Socrates' method and negative dialectic, and only secondarily to separate Socrates from Plato.

${ }^{65}$ See Plato, 3:505.

${ }^{66}$ History, 7:137. 
contention that Socrates taught that justice should be an end sought for its consequences. ${ }^{67}$ That necessarily implied that Virtue and Vice were only relative; that is to say, their assessment depended on the consequences for the security and happiness of the agent and the social whole. But this was the language ascribed to Protagoras and Prodicus. ${ }^{68}$ It appeared that the sophists were in agreement with Socrates (or Socrates with them), whereas Plato in holding justice to be an end in itself, contradicted his teacher. The Xenophontic historical Socrates did not appear to have maintained a strictly individual hedonism, as in the Platonic Protagoras. The selfish theory of morality seemed to Grote a Platonic property. It should not be understood, however, that Grote adhered solely to Xenophon's testimony. Grote clearly assumed that the Xenophontic practically-minded Socrates, the philanthropic preceptor, who inculcated self-control, temperance, piety, duty to parents and so on, and the Platonic Socrates who showed irony and used negative arguments, were related to each other. Socrates' cross-examination and his "theorising negative vein", were applied in a preceptorial form, to bear on practical conduct. ${ }^{69}$ Xenophon worked out and immortalized Socrates as a teacher: Plato elaborated the Socratic negative dialectic. Yet, Grote would not allow any historicity to the Socrates of the Republic.

\section{(ii) Socrates' Negative Dialectic}

For Grote, Socrates was definitely a greater sophist than the others. Grote

\footnotetext{
${ }^{67}$ Xenophon, Mem., I.2,18, and IV.3,1.

${ }^{68}$ Plato, 3:533.

${ }^{69}$ Plato, 3:562.
} 
recognized, like Schleiermacher ${ }^{70}$ that the greatness of Socrates as a philosopher lay in his method. He accepted, however, that Socratic analysis, which was intended to clear the mind from confusion and contradiction, ${ }^{71}$ was not performed "with a view to finality in the negative, but as the first stage towards an ulterior profit - as the preliminary purification indispensable to future positive result"..$^{2}$ Yet, Socrates, himself, never attained a positive result. ${ }^{73}$ That is, he never ascended beyond logical definition and dialectic cross-examination, nor did he assume the role of a moral preacher in the sense of his having a definite moral theory to impart to his audience. In the Platonic Apology there can be found Socrates' emphatic declaration that he was unable to communicate positive instruction. His declaration, Grote believed, should be taken seriously, because its superficial treatment has been the source of many misconceptions of Socrates' role in Greek philosophy and life. Socrates' assertion that he possessed

neither positive knowledge nor wisdom in his own person,-was frequently treated by his contemporaries as ironical. He was not supposed to be in earnest when he made it ... This interpretation of the character of Sokrates appears in the main to be preferred by modern

${ }^{70}$ For Schleiermacher Socratic dialectic aided the formation of the idea of science as a distinct subject of consciousness. See "The Worth of Socrates as a Philosopher", Philological Museum, 2(1833):552-3.

${ }^{71}$ F.M.Turner believes that Grote "thought Socrates' role in Greek intellectual development was reminiscent of the role Bentham had played in English legal philosophy. Socrates had awakened the 'analytical consciousness' of his fellow citizens ..." (Greek Heritage in Victorian Britain, New Haven and London 1981, p. 293). Turner's hypothesis cannot be true, or can be only half-true, for Bentham did not simply do what Socrates had done.

${ }^{72}$ History, 7:167; see also 7:124.

${ }^{73}$ Plato, 1:323. 
critics. $^{74}$

By not taking it seriously, one cannot understand why Socrates brought upon himself so much hostility by the Athenians. The Athenians hated him because they disbelieved his claim that he possessed no knowledge. Unlike the sophists, who accepted the current ethical and political sentiment, even with its unverified commonplaces, ${ }^{75}$ Socrates undermined and mistrusted authority, and ridiculed the common sentiment.

In his unpublished essay on Socrates Grote argued that

... the tone of his [Socrates'] discussions was eminently calculated to render him unpopular. The scope and tendency of his remarks was altogether sceptical: leading to no determinate or positive conclusion: suggesting difficulties on all sides, and resolving none: inculcating the necessity of subjecting all opinions to a vigorous enquiry: and impugning without reserve all authority, whether of poets, of teachers, or of ancestors ... [A]ll confidence in received opinions is undermined: nor is any thing offered beyond dark hints for the discovery of better ... The philosopher leaves his hearers in a state of conscious ignorance and self-mistrust: he has puzzled, unsettled, and humiliated them. $\mathrm{He}$ intends this indeed as a prelude to ulterior instruction, wherein positive results are to be established and enforced. But the public could not to be privy to these final parts of the process: they were witnesses chiefly to the striking dialectic assaults, to the upsetting of settled and dogmatical opinions ... ${ }^{76}$

Grote, nevertheless, admired Socrates. For if the sophists had practically enforced democratic feelings and widened the scope of education, Socrates enlarged the sphere of philosophic thought, and advocated in a way unparalleled in history the right of

${ }^{74}$ Plato, 1:291, emphasis added. See also 3:479.

${ }^{75}$ History, 7:132.

${ }^{76}$ BL Add. MS 29,522 (Essay on Socrates), fo. 164. Emphasis added. Cf., however, History, 7:165, where Grote argued that Socrates was a sceptic about physical questions, but certainly not about human affairs. In p. 168 he even argued that Socrates was "the reverse of a sceptic". Grote meant that Socrates never intended his logical inventiveness and dialectical manoeuvring to be taken as ends in themselves. Socrates wanted to disintegrate in order to reconstruct. Still the tendency of his speculation, i.e. the ruling effect of his conversation upon others, was sceptical. 
dissenting from King Nomos. ${ }^{77}$ Further it was Socrates, in Grote's judgement, who originally conceived the idea of "Ethical Science with its appropriate End". The end being, "the good and happiness of social man". ${ }^{78}$

As Victor Cousin had argued, there was not "a Socratic system, but there was a Socratic spirit. Socrates did not teach such or such a truth ... Socrates produced not a system, but an immense movement". ${ }^{79}$ For Grote the Socratic spirit, pointed to by Cousin somewhat vaguely, was directed towards scepticism, doubt and uncertainty. It led nowhere: it was simply the rise of individual distrust of unexamined faith and public orthodoxy: it was "warfare against the confident persuasion of knowledge, upon topics familiar to every one". ${ }^{80}$ The Socratic cross-examining elenchus was applied to testing general terms and implicit faith; it tended to the destruction of sentiment ${ }^{81}$ and the promotion of reason, and encouraged subjective reflection and individual conviction. The object of Socratic conversation was to create individual searchers after truth. ${ }^{82}$ It advocated the free employment of human critical reflection upon the current system of beliefs. This, according to Grote, regardless of reaching positive

\footnotetext{
${ }^{77}$ Plato, $1: 257$ and 2:513.

${ }^{78}$ History, 7:124, 129. See also, 7:118-19; and, Xenophon, Mem., IV.i.2, III.3-4.

${ }^{79}$ V.Cousin, Introduction to the History of Philosophy, Boston 1832, pp. 43-4.

${ }^{80}$ Plato, 1:322.
}

81 Grote criticized Socrates for his one-sided conception of Virtue (Virtue=Knowledge), which eliminated the sentimental function of human character. See History, 7:134-5 and Plato, 1:399-400. His criticism, obviously based on utilitarian standards, was not unlike Aristotle's who believed that Socrates was wrong in equating practical wisdom with knowledge. See Nicomachean Ethics, VI.xiii.3-4; also Magna Moralia, I.xxxiv.25 (1198a.10-12).

${ }^{82}$ Plato, 1:521. 
results, was of great material benefit. ${ }^{83}$

The Socratic dialectic aimed at scientific truth. It was Socrates, Grote asserted, who first brought to notice the objective and intellectual view of ethics, as distinguished from the subjective and emotional. Socrates further proved that subjective unanimity, based on the common emotion, did not exclude intellectual dissension. ${ }^{84}$ Obeying or sympathising with the general sentiment did not always mean intellectual concurrence.

(iii) The Decision of the Athenians to Condemn Socrates

Grote's early essay on Socrates was in fact an attempt to justify the Athenian decision to condemn Socrates. The modern conceptions of the trial and condemnation of Socrates represent the proceedings "in far blacker colours than an impartial spectator of the time would have done" ${ }^{85}$ The exaggerated odium thus raised against the Athenians' decision, could be explained, Grote argued, if a few points were taken into account.

(a) The modern idea of Socrates has been formed exclusively from the writings of his more enthusiastic pupils. We thus possess a sort of partial biography. ${ }^{86}$ Their accounts rendered him just and virtuous beyond measure.

${ }^{83}$ Plato, 1:293, 3:478-9.

${ }^{84}$ Plato, 1:324-5.

${ }^{85}$ BL Add. MS 29,522, fo. 162.

${ }^{86}$ History, 7:83-4. W.K.C.Guthrie remarked, like Grote, that "our information has to be taken mostly from men who not only knew him well but were his devoted admirers, and may therefore be thought suspiciously partial witnesses" (Socrates, Cambridge 1971, p. 69). 
We are familiar with all his virtues and excellences, with the justification for his weaknesses, and with the triumphant refutation of all the charges advanced against him. His peculiarities appear to us softened and coloured over by a friendly pencil; a puerile superstition is transformed into an amiable weakness: a malicious pleasure in humiliating and torturing antagonists is disguised under the exterior of exemplary modesty and self-degradation. ${ }^{87}$

Socrates was the most persevering and acute eristic of his age. ${ }^{88}$ To the Athenian public Socrates might have appeared only as an expert disputationist, who derived pleasure from objecting indiscriminately to any affirmative conviction. Moreover his tendency to cross-examine and convict of ignorance every distinguished man whom he could approach, was most unpopular, and it provoked violent enmity against him. ${ }^{89}$ It can be fairly assumed that most of the Athenians wished to get rid of him.

(b) The picture given of him in the Aristophanic Clouds, though "assuredly a gross caricature", must have borne some resemblance to the general idea of him, otherwise the drama could not succeed "as a piece of wit". ${ }^{90}$ Socrates, according to Grote, attended the lectures of the physical philosophers, and he was interested in that sort of philosophy. By identifying the two Aristophanes "must have suited his picture to the preconceptions of the mass of spectators". 91 The comic poets described what

87 BL Add. MS 29,522, fo. 162; emphasis added. Laertius indeed refers to Socrates' "disdainful, lofty spirit", to hyperoptikon kai megalofron (II.28).

${ }^{88}$ Plato, 3:479-80.

${ }^{89}$ History, 7:95; Plato, 1:258-9. Diogenes Laertius (II.21) mentioned that owing to his vehemence in argument "men set upon him with their fists or tore his hair out; and that for the most part he was despised and laughed at [gelasthai katafronoumenon]"; once he was also kicked.

${ }^{90}$ BL Add. MS 29,522, fo. 162.

${ }^{91}$ BL Add. MS 29,522, fo. 163. 
they actually saw or heard of Socrates. ${ }^{92}$ For Grote, though the modern critic was not bound to interpret Socrates in the light of the Aristophanic version, exactly as he was not required or even warranted to consider the sophistic movement on the basis of Plato's account of it, he should be ready to recognize that the comic poet gave expression to the historical figure of Socrates, i.e. as seen by his contemporaries.

(c) Socrates, it should be recognized, incurred the wrath of the Athenian public, since his negative dialectic usually brought him into conflict with those whom the public revered. Socrates was "an isolated and eccentric individual, a dissenter, not only departing altogether from the character and purposes general among his fellowcitizens, but also certain to incur dangerous antipathy, in so far as he publicly proclaimed what he was". ${ }^{93}$ Judging from what they saw, "they could treat him only as a proselytising sceptic - a character likely to be very odious to them". ${ }^{94}$ His monotonous method of conversation and his unvarying illustrations rendered him contemptible to the ordinary listener; and further he had not the air of being in earnest when he spoke..$^{95}$

${ }^{92}$ Plato, 1:534; History, 7:86. On the manner in which Socrates was handled by the comedians cf. Ritter, History of Ancient Philosophy, vol. II, pp. 25-6; Zeller, Socrates and the Socratic Schools, pp. 215-8. Lewes, Biographical History of Philosophy, vol. I, p. 156; J.Forster, "Socrates and the Sophists of Athens", Foreign Quarterly Review, 30(1843):364; C.Thirlwall, History of Greece, London 1837, vol. IV, pp. 246-252; R.D.Hampden, The Fathers of Greek Philosophy, Edinburgh 1862, pp. $353,357$.

93 Plato, 1:303, and BL Add. MS 29,522, fo. 164; see also fo. 165: "People wondered at him as an eccentric and out-of-the-way thinker".

${ }^{94}$ BL Add. MS 29,522, fo. 164.

${ }^{95}$ Ibid., fo. 165: His "homely illustrations derived from the commonest objects, seemed at first absolutely ridiculous: and his extreme ugliness added to the ludicrous effect." Macaulay wrote in this spirit: "I do not much wonder at the violence of the hatred which Socrates had provoked. He had evidently, a thorough love for making 
(d) Next Grote called attention to the political grounds of the trial. ${ }^{96}$ Socrates disapproved of the rules established by the democratic constitution of Athens. He never conceived that misgovernment could be checked by the public. Like Plato, believing in the art of politics "he did not harmonize either with oligarchical or democratical persons"..$^{97}$ His belief that the functions of government should legitimately be operated by those who knew the best way to exercise them, contributed to his condemnation..$^{98}$ Further his earnest conviction about his religious mission, must have appeared to the Athenian public as an offensive heresy: a desertion of the recognized gods of Athens. ${ }^{99}$ Socrates' philosophy thus turned against individual freedom and self-rule established by the democratic constitution of Athens; it was antireligious or non-religious, and did not comply with the social standards of Athenian life. The wonder is, after all, not that the indictment was presented at last, but that such indictment had not been presented long before. ${ }^{100}$

men look small. There was a meek maliciousness about him which gave wounds which must have smarted long, and his command of temper was more provoking than noisy triumph and insolence would have been" (quoted in R.N.Cross, Socrates the man and his mission, London 1914, pp. 135-6).

${ }^{96}$ It is worth observing that even fifty years after the trial Aeschines addressed the following words to an Athenian jury: "You put to death Socrates the sophist, because he was shown to have been the teacher of Critias" (Against Timarchus, 173).

${ }^{97}$ BL Add. MS 29,522, fo. 164.

${ }^{98}$ History, 7:138-9.

${ }^{99}$ History, 7:91; Plato, 1:286-7.

${ }^{100}$ History, 7:141; and Plato, 1:265, and 2:493: "Nowhere else except at Athens could Socrates have gone on until seventy years of age talking freely in the marketplace against the received political and religious orthodoxy." A.P.Stanley agreed with Grote in posing this question, in his "Socrates", Quarterly Review, 88(1850):54; similarly F.D.Maurice, Moral and Metaphysical Philsophy, London 1882, vol. I, p.130. The same wonder is expressed by T.C.Brickhouse and N.D.Smith in their recent work, 
(e) Furthermore Grote believed, on the testimony of Xenophon, and also on the internal evidence of Plato's Apology, that Socrates brought upon him the capital sentence partly by his own concurrence. The Athenian dikasts, instead of hearing a man addressing them with reverence and soliciting their feelings of clemency, "now heard themselves lectured by a philosopher who stood before them like a fearless and invulnerable superior, beyond their power, though awaiting their verdict" ${ }^{101}$ Socrates in Grote's judgement behaved in such a way because he had the highest idea of his divinely determined apostolic missionary plan, and because he calculated that his defence at the trial would be the most striking lesson presented to the youth of Athens. It would prove to them that a sincere conviction should not be abated by fear and human weakness, that what mattered more was the application of the elenchus upon pretensions of infallibility, that reason should always prevail over sentiment and prejudice. $^{102}$

An amalgam of reasons (religious, political, and social) thus led the Athenians to condemn him. Though an act of intolerance, ${ }^{103}$ it came as an inevitable result. As tested by Athenian standards, Socrates was guilty. ${ }^{104}$ Grote believed that despite his

Socrates on Trial, Oxford 1989, p. 23. See also I.F.Stone, "Why did they wait until he was seventy?", in his Trial of Socrates, Boston, Toronto, 1988, pp. 133-9; and J.W.Roberts, City of Sokrates, London and N.Y. 1984, p. 73.

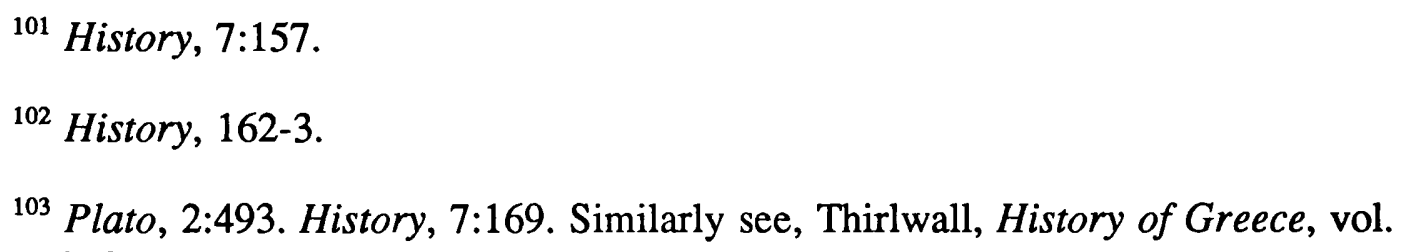
IV, p. 273.

${ }^{104}$ P.W.Forchhammer, in his Die Athener und Sokrates (Berlin 1837), was the first who argued that Socrates was guilty; Hegel also believed that to some extent. Grote rejected, however, Forchhammer's conclusions, which reflected an unwarranted hostility against Socrates, History, 7:81-2. 
antipathy to democracy Socrates accepted the city. Socrates' theory of politics was in substance apolitical: he "approved neither of democracy nor of oligarchy". ${ }^{105}$ In the dramatic scene of the Crito Grote rightly conceived the effort of Socrates to reconcile two distinct elements: constitutional allegiance and Socratic individuality. ${ }^{106}$

${ }^{105}$ History, 7:139.

106 Plato, 1:302-304. See Laertius, II.24, for Socrates' "attachment to the democracy". Grote however did not hold that he was attached to it, but only that he accepted it. On Grote's analysis of the Crito, as related to the Apology, see Richard Kraut, Socrates and the State, Princeton 1984, p. 11n.18, pp. 54-60. Kraut points out Popper's indebtedness to Grote as far as his interpretation of the Socratic problem is concerned (p. 206). 


\section{Chapter 8}

\section{THE RECEPTION OF GROTE'S IDEAS ON THE SOPHISTS \\ AND SOCRATES}

I

\section{The Sophists}

Grote's defence of the sophists was first received with scepticism by nineteenth-century classical scholars. But they soon acknowledged that Grote's argument in favour of ancient sophistike deserved consideration. Alexander Grant confessed that the "paradox" of Grote's argument concerning the sophists excited in him a protest against it, which found expression in the first edition of his The Ethics of Aristotle, in 1857. In 1885, when the fourth edition of his work appeared, he was able to point out that "Time and reflection and the remarks of various scholars who have taken part in the controversy, would seem to necessitate the modification of that protest".' G.T.Kingdom, who based on Grote's 'utilitarian influence' his disagreement with him on matters of ancient history and classical scholarship, ${ }^{2}$ displayed rather too much influence by Grote, when he confessed, to give the least example, that Plato treated Protagoras with marked respect and deference. Protagoras in the dialogue bearing his name gave utterance to opinions which "far from being extreme or palpably immoral, are for the most part in agreement with the common' sense of

\footnotetext{
${ }^{1}$ Grant, The Ethics of Aristotle, London 1885, vol. I, p. 105.

2 Similarly James Frederick Ferrier claimed that Grote defended the sophists because their views "were not unlike those propounded by the Utilitarians of the present day" (A.Grant and E.L.Lushington (ed.), Lectures on Greek Philosophy and other Philosophical Remains of James Frederick Ferrier, Edinburgh and London 1866, vol. I, p. 207).
} 
mankind, and may be said to be moderate and just". ${ }^{3}$ E.M.Cope, a Cambridge scholar, who embarked on the task of upholding the old conception of ancient sophism, expressed his desire to speak of Grote "with the respect due to the great name which he has made himself in literature, and the important services which he has conferred upon Greek history". ${ }^{4}$ In the case of the sophists Grote, in Cope's view, invested his account with the greatest ingenuity and bestowed upon his subject a novel aspect, as well as new conclusions no less plausible. J.S.Blackie, who was generally averse to the new interpretation of the sophistic character, was made to admit that there was nothing "necessarily bad or immoral in the profession or teaching of a sophist; some of them, evidently, such as Protagoras and Prodicus, even on the witness of their great adversary Plato, were very proper and respectable gentlemen". 5

Grote's arguments gave rise to a discussion about the sophists and their role in Greek society and politics. His interpretation of them proved influential in three aspects. It placed the appearance of the sophistic movement in the context of ancient democracy. It also questioned the Platonic explanation of the role of sophistike, and made scholars doubt whether Plato's feelings towards the sophists coincided with those generally held in fifth century Athens. Further, Grote's emphasis on the individual character of the sophists led to the recognition that they did not form a

${ }^{3}$ Kingdom, An Essay on the 'Protagoras' of Plato in which a reply is furnished to some modern critics, Cambridge and London 1875, p. 6. Kingdon did not neglect to praise Grote's "vast power of research in matters of historic detail" (p. 2).

${ }^{4}$ Cope, "The Sophists", [I] The Journal of Classical and Sacred Philology, 1(1854):146. Cope dedicated to Grote his Introduction to Aristotle's Rhetoric, Cambridge 1867.

${ }^{5}$ Blackie, Four Phases of Morals. Socrates, Aristotle, Christianity, Utilitarianism, Edinburgh 1871, p. 30. 
school with common doctrines and purposes. There could be found different 'types' of sophists among them; some were distinguished for their ability and learning. The sophists, it was allowed, contributed in their own way to the development of philosophic thought.

It was acknowledged that Grote was correct in rehabilitating the sophists in their place in history, as an integral part of Athenian society, and ancient Greece in general. ${ }^{6}$ Democracy required, in ancient Greece, direct participation in the sovereign power, the Assembly and the law-courts, and the sophists offered to teach the means of persuasion, and qualify people in accordance to the prevalent idea of a good citizen. The appearance of these teachers in Athens was now regarded as a sign of the times. Earlier philosophy resulted in abstractions from nature; "but now thought was directed to the practical requirements of life and the Sophists supplied a recognized want in the education of the age". The sophistic teaching marked the transition from cosmological philosophy to philosophy related to the thinking and willing individual. Athenian democracy and its great civilization was connected with the influence of education on the character of people. Athens owed its greatness to democracy, and in

6 See, J.T.Champlin, "Grote's Greece", Christian Review, 16(1851):501; L.Campbell, "The Platonic Dialogues", Quarterly Review, 112(1862):319; W.Whewell, Platonic Dialogues, Cambridge 1860, vol. II, pp. v-x and "Grote's Plato", Fraser's Magazine, 73(1866):413; Grant, The Ethics of Aristotle, vol. I, p. 105; T.Gomperz, Greek Thinkers, London 1905, vol. I, pp. 435-6; B.Jowett, Dialogues of Plato, Oxford 1953, vol. III, p. 329; H.Sidgwick, Lectures, pp. 354-5 and Outlines of the History of Ethics, London 1896, p. 21.

${ }^{7}$ C.W.Collins, Plato, Edinburgh and London 1874, p. 25; see also D.F.Nevill, Plato, The Apology of Socrates, London 1901, p. 15. 
that democratic period flourished the "golden age of education". ${ }^{8}$

Scholars recognized that Plato's representation of the sophists should be accepted with reservations. His dislike of democracy led him to underestimate the role of the sophists in life and education. ${ }^{9}$ William Mure agreed with Grote that the charges against the sophists "may be ascribed to the spirit of malicious exaggeration in which Plato, throughout, handles [their] character and habits". ${ }^{10}$ Gilbert Murray, whose views were greatly influenced by Grote, pointed to the unfairness of depending on Plato to describe these eminent teachers who after all were "the spiritual and intellectual representatives of the age of Pericles".." Van Oordt, argued in a proper Grotean spirit that Plato's aristocratic position, directly at variance with the ideas prevailing at Athens, gave bitter expression to his dislike of men who made a study of rhetoric. ${ }^{12}$ Edwin .H.Gifford called attention to the extreme contrast between "the stigma ... affixed by Plato to the name 'sophist' and its original use as a title of honour". Until the mid-nineteenth century, Gifford went on, Plato's representation of the sophists was taken as corresponding more or less closely to the real character of the sophists of his day. "But the confidence with which this view was entertained

${ }^{8}$ A.D.Godley, Socrates and Athenian Society in his day, A Biographical Sketch, London 1896, p. 43; J.W.G. Van Oordt, Plato and the times he lived in, Oxford 1895, p. 26; F.B.Jevons, A History of Greek Literature, London 1886, p. 368.

${ }^{9}$ See J.S.Mill's remarks, in "Grote's History of Greece" [II], C.W., vol. XI, p. 329. See also William Wayte, Platonis Protagoras, Cambridge 1871, pp. vii, 86-7.

${ }^{10}$ Mure, A Critical History of the Language and Literature of Antient Greece, London 1853, vol.IV, p. 37n.3.

${ }^{11}$ Murray, A History of Ancient Greek Literature, London 1898, pp. 161 and 164.

${ }^{12}$ Van Oordt, Plato, pp. 114-16. 
received a sudden shock when Mr. Grote published his famous defence". ${ }^{13}$

If Plato, however, criticized the sophistic movement, he did not obscure his respect for distinguished sophists. Gonzalez Lodge acknowledged that Plato represents Gorgias as a man of "upright aims and high attainments". ${ }^{14}$ Henry Bleckly, who spoke about Grote with marked respect, stated that Protagoras, like Gorgias, "was a teacher of established and deserved reputation". ${ }^{15}$ W.H.Thompson similarly admitted that Protagoras's discourse "is quite as moral in its tendency, and at least as elegant in style", and further he acknowledged his agreement with Grote that Gorgias' treatment by Plato, in the dialogue that bears his name "is respectful rather than contumelious". ${ }^{16}$

The role of the sophists in the advancement of philosophical reasoning was frequently acknowledged shortly after the publication of Grote's work, even though traditional views continued to be held among students of classical learning. Blakey argued that "it may safely and consistently be admitted, that there might be many distinguished and able men among the Sophists, who really and disinterestedly laboured for the solid and useful instruction of mankind". ${ }^{17}$ The conventional treatment of the sophists as the corruptors of the minds of youth have been corrected,

${ }^{13}$ Gifford, The Euthydemus of Plato, Oxford 1905, p. 43.

${ }^{14}$ Lodge, Plato, 'Gorgias', London 1890, p. 15.

${ }^{15}$ Bleckly, Socrates and the Athenians, London 1884, p. 83.

${ }^{16}$ Thompson, The Gorgias of Plato, ed. George Long, London 1871, pp. iii-iv.

${ }^{17}$ Robert Blakey, Historical Sketch of Logic, from the earliest times to the present day, London and Edinburgh 1851, p. 14. E.Zeller who at the beginning was inflexible in his attitude (see "The development of monotheism among the Greeks", Contemporary Review, 4(1867):367), allowed that the sophists should occupy a conspicuous place in history. See Plato and the Older Academy, London 1876, p. 183. 
Blakey continued, "by some writers of judgment and reputation; [and] in particular, by Mr Grote". ${ }^{18}$ A.W.Benn criticized Zeller for his insistence on the 'old' idea of the sophists and pointed out that the misconception was "long ago corrected by Grote". ${ }^{19}$ Whewell argued that Grote had proved, "in a manner which combines the startling effect arising from great novelty with the solid conviction arising from plain good sense", that the sophists were diverse in their tenets, character, and objects. ${ }^{20}$ The first step towards appreciating the sophistic movement was the distinction drawn between the sophists themselves, and the recognition that Plato's portrait of them as a general type of character was in fact a misrepresentation. This distinction did not deny the existence of a common tendency which permeated the movement as a whole. But this tendency (namely, the tendency to make philosophy relevant to human life), was the result of diverse methods and distinct theoretical approaches. ${ }^{21}$

Under Grote's influence scholars proceeded to distinguish between types of sophists, or groups of individuals who differed in some important respects from one another. Robert Adamson placed a more philosophical sophist, as represented for

${ }^{18}$ Blakey, Ibid., p. 9.

19 Benn, "The place of Socrates in Greek Philosophy", Westminster Review, 114(1880):28. Cf. Edward Caird, "Plato, and the other companions of Socrates", North British Review, 43(1865):360.

${ }^{20}$ W.Whewell, The Platonic Dialogues for English Readers, Cambridge 1860, vol. II, p. vi; similarly J.Anster, "Grote's Greece", Dublin University Magazine, 45(1855):489. It has been of decisive importance that the sophists should have ceased to be seeing as a 'sect'. See D.G.Ritchie's remarks on Grote, Plato, Edinburgh 1902, pp. 63-4.

${ }^{21}$ Grote's argument that the sophists were not a sect prevailed very soon. See, e.g., R.W.Mackay, The Sophistes of Plato, London and Edinburgh 1868, pp. 14-15; Cope, "The Sophists", Journal of Classical and Sacred Philology, 1(1854):181; A.W.Benn, The Philosophy of Greece, London 1898, p. 144; W.J.M.Starkie, The 'Clouds', London 1911, p. xl. 
instance by Protagoras, in a second category, being preceded by an earlier type which laid an almost exclusive stress on rhetoric and the acquisition of political power, and succeeded by "the Eristics, a rather contemptible species, whose stock-in-trade seems to have consisted of a collection of dialectical puzzles, mainly Eleatic in origin, but to some extent originating in the teaching of Socrates". ${ }^{22}$ Most scholars called attention to a degenerate class of sophists, which differed both socially and intellectually from a more elevated class, which included Protagoras and Gorgias. ${ }^{23}$ The former class was represented in Plato's day by Euthydemus and his brother, and it can be called the "interrogating" class as contrasted to the "lecturing" class, which included sophists of the greatest ability. ${ }^{24}$

Grote's analysis of Protagoras' 'man-measure' doctrine was hotly challenged. Grote argued that Plato had misinterpreted Protagoras' doctrine. Protagoras' so-called 'subjectivism' was not confined to sense-perceptions nor did it exclude the plain fact that between judgements equally true, one might be better than another. Grote's critics never took into account his acknowledgement, to the effect that "It is not to be supposed that Protagoras ever admitted all men to be equally wise, though Plato puts

${ }^{22}$ R.Adamson, The Development of Greek Philosophy, ed. by W.R.Sorley and R.P.Hardie, Edinburgh and London 1908, p. 69. See further, F.D.Maurice, Moral and Metaphysical Philosophy, London 1882 (first edn, 1850), vol. I, pp. 116 and 118-19.

${ }^{23}$ P.Smith emphasized the difference between the philosophy of the "celebrated" Protagoras and the teaching of subsequent rhetors (History of the Ancient World, London 1873, vol. I, pp. 481-2). See also W.Windelband, History of Ancient Philosophy, London 1900, p. 111; Nevill, Apology, pp. 14-15; Gifford, Euthydemus, pp. 11, 45.

${ }^{24}$ George H.Wells, The Euthydemus of Plato, London and Cambridge 1881, p. xii. See also, Godley, Socrates, pp. 42-3. 
such an admission into his mouth". ${ }^{25}$ Further, Grote contended that the doctrine of Protagoras offered the only basis on which philosophy as "reasoned truth" could stand. It by no means lowered the force of argumentative scrutiny; on the contrary it allowed free-thinking and secured mutual social and moral respect. Yet scholars received Grote's argument as being equal to a vindication of an all-embracing theory of relativism, that would penetrate the whole world of the phenomenal and noumenal objects, and annihilate the possibility of objective scientific truth. Campbell believed that Grote's argument on the man-measure doctrine was similar to Pyrrhonian scepticism, to the extent that it confounded mere individual belief with belief grounded on evidence. ${ }^{26}$ J.S.Mill, who was otherwise in agreement with Grote's interpretation of Plato, chose to separate himself from what Grote claimed regarding the H.M. doctrine. The truth of an opinion, remarked Mill, was a different thing from the reception of it as true, in so far as it involved reference to an external standard. Things were doubtlessly relative to the believing mind, but, moreover, (and perhaps more importantly) were relative to the matter of fact which the belief was about.

We grant that, according to the philosophy we hold in common with Mr. Grote, the fact itself, if knowable to us, is relative to our perceptions - to our senses of our internal consciousness; and our opinion about the fact is so too; but the truth of the opinion is a question of relation between these two relatives, one of which is an

25 Plato, 2:352. Benn, Philosophy of Greece, pp.131-2, followed Grote. F.C.S.Schiller's argument is mostly based on Grote, Plato or Protagoras? Being a critical examination of the Protagoras' speech in the 'Theaetetus' with some remarks upon error, Oxford and London 1908, especially pp. 8, 16-17, 22. Schiller argued that Protagoras was the first great pragmatist and Plato's attempt to reduce his philosophy to mere sensationalism, then in vogue, was clearly motivated by his one-sided intellectual idealism.

${ }^{26}$ L.Campbell, "Grote's Plato", Quarterly Review, 119(1866):144. 
objective standard for the other. ${ }^{27}$

Cope, who produced a separate work to disprove Grote, and whose principal object, as he himself determined it, was to defend Plato against any charges of prejudice and inconsistency "so freely brought against him by Mr Grote in his recent work", believed that Protagoras could be shown to have taken a narrower view of his doctrine than Grote assumed. ${ }^{28}$ Grote's theory of relativism, in Cope's judgement, lacked theoretical persuasiveness. Mathematics and the sciences could not stand without the certainty that some objective standards existed as realities per se. In the domain of axiomatic sciences "individual judgment is for no value". Here we are in need of the artist, the man of skill and specific knowledge..$^{29}$

\section{II}

\section{Socrates}

Bleckly was correct when he stated that Grote's picture of Socrates "bears the impress of impartiality and truth, doing justice ... to the Athenian people, and not less so to Socrates". ${ }^{30}$ Grote admired Socrates, as the parens philosophiae, and did him justice. He admired the Athenians and found reasons to justify their conduct. In Socrates, whom he admired, Grote found the unrivalled energy of a philosophic genius, the negative argument which promoted abstract reasoning, and the Baconian

\footnotetext{
27 J.S.Mill, C.W., vol. XI, p. 427.

${ }^{28}$ E.M.Cope, Plato's 'Theatetus' and Mr Grote's criticisms, Cambridge 1866, pp. 3 and 14.

${ }^{29}$ Ibid., p. 27.

${ }^{30}$ Bleckly, Socrates and the Athenians, p. 6, emphasis added.
} 
radical spirit which paved the way for the development of formal logic. Socrates further established the science of Ethics showing that it should rest on a profound philosophic basis, and defended warmly the right to individual dissent. Socrates, who in theory did not appear to have advocated the democratic system of government, in practice fully enjoyed democratic liberty. Nowhere could he practise his negative dialectic except within the Athenian agora; no other city could have tolerated him for fifty years or more. ${ }^{31}$

After Grote Socrates began to be treated as an ordinary human being. Grote's bold argument regarding Socrates "astonished nineteenth-century British readers". ${ }^{32}$ But Grote's contemporaries came gradually to realize that Socrates could not have been an agreeable figure to his fellow-citizens. While subsequent generations saw in the face of Socrates the immortal genius great in thought and consistent in action, the Athenians saw, T.Healey believed, "little more than an eccentric old gentleman, poor, and of no great social or civic repute, who was meeting them daily at every point and corner of the city with ideas and recommendations opposed to their dearest instincts and oldest prejudices". ${ }^{33}$ Socrates disregarded all profitable labour and abstained from all political business; no doubt, his practices gave to the industrious citizens of Athens

${ }^{31}$ Bleckly emphasized that Socrates' career confirms the "general fairness and toleration of the Athenians", Ibid., p. 42.

${ }^{32}$ F.M.Turner, Greek Heritage in Victorian Britain, New Haven and London 1981, p. 292.

33 Healey, "The Socrates of the Athenian People", Cornhill Magazine, 9(1864):579. See also Maurice Croiset, Aristophanes and the Political Parties at Athens, London 1909 (first edn, Paris 1889), p. 98. 
the impression that he led a remarkably idle and purposeless life. ${ }^{34}$ Zeller remarked that Socrates must have appeared to his contemporaries a "strange person, altogether unlike anyone else". His intellectual discipline was something explicitly contrasted with the beliefs of the Greeks. All these characteristics were foreign to the habits of his contemporaries. ${ }^{35}$ His general manner of life, as well as his constant argumentation, Nevill argued, were sufficient reasons for rendering him odious to his contemporaries. $^{36}$ No doubt, asserted Aston Leigh, "many thought Socrates unnecessarily and harshly disputative". ${ }^{37}$

In the statements above, which in effect created at once a break with tradition, the purpose was to throw light on the grounds of Socrates' conviction. The inference was that Socrates was by no means a favourite Athenian son. No scholar failed to recognize that Socrates' political philosophy was far from countenancing the current democratic regime.

James Riddell and George Stock, both editors of Plato's Apology and much influenced by Grote's recent arguments, went on to ascribe Socrates' condemnation to the fact that the Athenians could not have endured Socrates in the growing political sensitivity of the restored democracy, after the events of $404 .^{38}$ Godley argued that

${ }^{34}$ J.R.Thursfield, "Mr. Grote's Plato", Westminster Review, 84(1865):470; similarly Blackie, Four Phases of Morals, p. 8.

${ }^{35}$ E.Zeller, Socrates and the Socratic Schools, London 1885, pp. 78-9.

${ }^{36}$ Nevill, Apology, pp. 18-9.

${ }^{37}$ A.Leigh, The Story of Philosophy, London 1881, p. 61.

38 J.Riddell, The Apology of Plato, Oxford 1867, p. xxix. George Stock paid his tribute to "the inexhaustible mine of learning contained in Grote's writings" (The Apology of Plato, Oxford 1887, p. 4). Stock believed that Socrates' "dicasts went home to their supper that day with the comfortable assurance that they had 
there must have been a great difference between the Socratic view of politics and the view held by the Athenian democrats. ${ }^{39}$ Bleckly developed an argument which justified the Athenians for their decision to condemn Socrates. Socrates did not lose an opportunity to perplex them regarding the divine. He openly criticized them for having only a superficial knowledge of piety. ${ }^{40}$

Grote also succeeded in questioning the prevalent idea of Socrates as a professional enemy of the sophists. ${ }^{41}$ The question was now put directly: "Was Socrates a Sophist?"42 George Henry Wells answered 'yes and no'. His answer corresponded to Grote's assumption of the essential relationship between them. For Grote never identified fully the two. Yet, he pointed out that Socrates was related to the sophists as a part to the whole. Socrates was a continuation of the humanitarian movement; his method originated from within the sophistic movement and not in opposition to it. Both wished to emancipate the individual and strengthen his critical insight. But, as Gomperz argued, Socrates was a philosophic radical in a way the sophists were not. ${ }^{43}$ His tendency was to demolish the old foundations in order to erect the principles of the science of ethics. The sophists were more conservative in

conscientiously discharged their duty as good citizens" (p. 22). F.Ueberweg similarly held that Grote developed "very comprehensively and exactly" the political bearings of the trial (History of Philosophy, New York 1874, vol. I, p. 82).

${ }^{39}$ Godley, Socrates, pp. 26-7.

${ }^{40}$ Bleckly, Socrates and the Athenians, p. 56.

${ }^{41}$ Walter Pater recognised, like Grote, that the idea of Socrates as an enemy of the sophists originated "through the influence of Plato" (Plato and Platonism, London and N.Y. 1893, p. 88).

${ }^{42}$ G.H.Wells, The Euthydemus of Plato, London and Cambridge 1881, p. xv.

${ }^{43}$ Gomperz, Greek Thinkers, vol. II, p. 80. 
their aspirations, more positive in their instructions. They taught what the age asked for, in harmony with historical requirements.

Scholars understood that in a history of ancient philosophy the position of Socrates as related to the sophistic thought should have been explained. Plato put Socrates to antagonize the sophists, but his point of view was disputable. Ueberweg accepted Grote's argument, namely that there had been a line of continuity between Socrates and the sophists. The sophists cultivated the intellect and prepared the way for the destruction of the traditional naivete through Socratic dialectic. ${ }^{44}$

Some scholars went on to admit more readily that Socrates was in many ways not unlike the sophists. Sidgwick went even further and eliminated any difference between them. ${ }^{45}$ Wenley professed that Socrates adopted in substance what he believed to be valuable in their methods, and imitated them in their habit to converse in social gatherings about subjects related to actual experience. Pater did not scruple to affirm that "Socrates in truth was a Sophist", and in his day scarcely distinguishable from his so-called 'rivals' ${ }^{46}$ Hyslop, Stock and Godley maintained that only external and insubstantial differences existed between Socrates and the sophists. ${ }^{47}$

\footnotetext{
${ }^{44}$ Ueberweg, History of Philosophy, vol. I, pp. 72-3, 80-1. In the same spirit see Grant, The Ethics of Aristotle, vol. I, p. 144; Adamson, Development of Greek Philosophy, p. 72.

${ }^{45}$ Sidgwick, "The Sophists", in the Lectures on the Philosophy of Kant, London 1905 , p. 338.

${ }^{46}$ See R.N.Wenley, Socrates and Christ. A Study in the Philosophy of Religion, Edinburgh and London 1889, pp. 36-7, 60; cf. pp. 26-7. Pater, Plato and Platonism, p. 90. Riddell, who nevertheless was more attached to the traditional interpretation, seems to have been wavering in this matter and called Socrates a sophist (see, Apology, p. xxix).

47 "Socrates no doubt belongs to a class of men which plays a large part in the intellectual history of the time - I mean the ... "sophists'" (Godley, Socrates, p. 41).
} 
Before Grote it was commonly believed that Socrates had been a leader of a school, and that he developed certain doctrines. He pretended ignorance; but in reality he was a qualified teacher and an earnest moral reformer. He upheld a definite philosophical system which comprised the principles of ethical action. In the 1860 s Socrates' philosophy was interpreted quite differently. Socrates, it was argued, "had no theories to defend". ${ }^{48}$ Like Descartes, Socrates came primarily to demolish, to employ the negative arm of his thought in order to clear up the mind from a priori confidence. Socrates' entire novelty, argued MacIlwaine, who regarded Grote as the scholar most perfectly right in his estimation of Socrates' philosophic significance, ${ }^{49}$ was to be found in his negative preoccupation. ${ }^{50}$ Socrates was far from being able to construct a philosophic edifice of his own. He was not dogmatic in any sense but a ceaseless researcher, who believed himself to be an unsuccessful researcher. It was

James H.Hyslop argued that Socrates was "a sophist in the best sense of that term ... In regard to method ... Socrates was a sophist" (The Ethics of the Greek Philosophers. Socrates, Plato and Aristotle, New York, Chicago, London 1903, p. 26). See also W.W.Merry, Aristophanes, 'The Clouds', Oxford 1879, p. viii; Stock, The Apology of Plato, pp.15-6. Cf. W.H.Thompson, "The Nubes of Aristophanes", Journal of Philology, 12(1882):171; and J.D.Morell, Manual of History of Philosophy, London 1885 , p. 55.

${ }^{48}$ Anon. "Jowett's Plato", London Quarterly Review, 37(1871):96.

${ }^{49}$ In Italy A.Labriola similarly found in Grote "la caratteristica piu completa $e$ piu perfetta della personalita de Socrate". Labriola argued that Grote was perfectly right in not ascribing to Socrates any principia, or sets of opinions (Socrate (first ed. 1871), 4th ed., Bari 1947, p. 1. n.1 and p. 24; quoted in M.Montuori, Socrates, An Approach, Amsterdam 1988, pp. 28-9, n.12). Montuori points out that Grote was also followed by A.Fouillee and A.Croiset in France, and A.Doring in Germany.

50 W.Macllwaine, "The Mission of Socrates", Dublin University Magazine, 82(1873):304. 
his method of inquiry which guaranteed to himself the perennial debt of philosophy. ${ }^{51}$ His contribution to philosophy consisted in advocating the rules of empirical enquiry, both in the field of morals and physics, in a period dominated by metaphysical curiosity. ${ }^{52}$

In conclusion, Grote's arguments related to Socrates and the sophists proved influential. Grote contended that the questions related to Socrates and the sophists should be resubmitted to historical and philosophical examination. The traditional view appeared to him biased and as turning against common experience. In the second half of the nineteenth century the novelty of Grote's point of view surprised and, sometimes, provoked scholars. Some of them believed that his arguments on the sophists were dictated by his desire to give an historical justification of contemporary philosophic radicalism..$^{53}$ The sophists were openly compared with the Radicals. ${ }^{54}$ Grote's approach to the sophists, however, did not render them 'Radicals'. The sophists were seen as not attacking current beliefs; they did not conceive an in-depth reform of legal or political structures. Further, no common tenets or philosophic

\footnotetext{
${ }^{51}$ See D.B.Monro, "Jowett's Plato", Quarterly Review, 131(1871):496; Gomperz, Greek Thinkers, vol. II, p. 57.

${ }^{52}$ Hyslop, Ethics of the Greek Philosophers, pp. 16-7.

${ }^{53}$ See Mackay, The Sophistes of Plato, p. 47; Blackie, Horae Hellenicae, London 1874, p. 197. As A.E.Dodds noted Grote was the "first [who] seriously attempted to upset the verdict of Plato"; but the late-Victorian scholars believed that the sophists "were no better than Benthamites". See "The Sophistic Movement and the Failure of Greek Liberalism", in The Ancient Concept of Progress and other Essays on Greek Literature and Belief, Oxford 1973, pp. 92-3.

${ }^{54}$ The tendency in recent times is much similar. F.E.Sparshott, speaking about Grote's defence of the sophists, called them "philosophic radicals", "Introduction", in J.S.Mill's C.W., vol. XI, pp. xxii and xxxiii. See also R.Borchardt (ed.), Four Dialogues of Plato, trans. by J.S.Mill, London 1946, p. 21; Turner, Greek Heritage in Victorian Britain, pp. 392, 396.
} 
principles could be discovered in their teaching. Though they supported the liberal arts, they were not the originators of a more liberal position in Athenian politics. Time showed that Grote's theory concerning Socrates and the sophists was far more influential and stimulating than some of his contemporaries could have imagined. 


\section{CONCLUSION}

There is a certain amount of truth in G.C.Lewis' saying, in a letter to Grote, that "All other 'Histories' of Greece are superseded by your work; and those who treat the subject hereafter must take your treatment of it as their starting-point". ${ }^{1}$ A great deal of truth is also in Peter Anton's remark that it is very difficult to conceive that Grote's History will ever become obsolete: being written with "so much genius and care" Grote's History will survive as literary work even when it is found to be faulty as history. ${ }^{2}$ Someone has indeed to go through Grote's laborious work to understand Momigliano's "pride" in being a teacher "in the College which for more than forty years provided so many joys and so many tribulations for George Grote". ${ }^{3}$ Another distinguished ancient historian, the late Moses Finley had no hesitation in asserting that the History of Greece, as written by the "liberal and banker George Grote ... was the first major modern work on the subject (and one of the greatest ever written)". ${ }^{4}$

Grote has been the great historian of Athens not merely because he first rendered Athenian democracy intelligible but also because the ancient democratic ideal, as actualized in the fertile environment of Attica, was throughout all his

\footnotetext{
${ }^{1}$ Quoted in W.Smith, "George Grote", Quarterly Review, 135(1873):121. In the same spirit W.Macllwraith wrote, The Life of George Grote, London 1885, p. 29: "Probably a more attractive history of Greece will, in process of time, be written, but such a task has only been made more possible by the firm and solid foundation which George Grote has laid."

${ }^{2}$ P.Anton, Masters in History, Edinburgh 1880, p. 63.

${ }^{3}$ A.Momigliano, George Grote and the Study of Greek History, London 1952, p. 20.
}

${ }^{4}$ M.I.Finley, Aspects of Antiquity, London 1968, p. 29, emphasis added. 
historical and philosophical works, a constant source of reference. Plato's political thought is criticized in light of Periclean Athens. The sophists are considered inseparable from a progressing society as the natural offsprings of a system of government which was founded on the rule of law. Rhetoric emerged as the only acceptable means of obtaining the consent of the governed. Rhetoric was not simply the 'art of words', an empty literary device: its aim was persuasion, but the means were based on rational argument. In Sparta where decisions were enforced by the arbitrary will of an oligarchy, the sophists had no place. The Athenian state appeared to Grote a remarkable phenomenon in the history of politics inasmuch as it was largely based on the power of free speech. Legislation in Athens was the result of discussion; and that is why the minority felt bound to acquiesce in the decisions of the many. Athens' unique position in human history consists of its intellectual and cultural supremacy. But such supremacy, Grote argued, should be seen as the fruit of its political freedom.

By his very existence, Socrates, symbolized the idea of individual liberty. Nowhere but in the tolerant climate of fifth century Athens could Socrates have been allowed to employ his annoying and often offensive method of cross-examination. For the Athenians he died justly, because he exhausted the patience and forbearance of his fellow-citizens. Nobody would have ventured to condemn him merely because of his method. His general manner, and especially his religious mission, as well as his arguments in favour of a science (or art) of political rule, were regarded as undermining the roots of their constitution. And the Athenians, as Grote contended, were zealously faithful to their constitution.

We can credit Grote with a liberal 'bias', in so far as the idea of liberty was 
always present in his mind, and doubtlessly shaped the direction of some of his most celebrated arguments. Indeed, one can examine Grote's work with reference to Victorian Liberalism, and argue that the scope and limits of his work were partly determined by that movement. It is not wrong to do this, but such an interpretation of Grote's achievement understates his contribution to classical studies. It cannot be denied that he was a utilitarian throughout his life, but his adherence to utilitarianism did not distort his work in ancient history. As William Smith argued, his philosophical background and his experience as a politician,

enabled him to see and teach what, like all great lessons, seems so simple when once learnt, that the most refined and intellectual people that ever lived could form and govern their states on principles very strange to us, and even follow the leadership of Cleon and the teaching of the Sophists, without being madmen or fools, or, at the least, bugbears to all of sound faith in politics and philosophy. ${ }^{5}$

Grote's greatest contributions in the early 1840 s were to discredit the belief that Athenian democracy was inherently corrupt, to rehabilitate the name of the sophists, to refute those who uncritically asserted that a demagogos was a title of moral and political depravity, and to disclaim the assertion that Athenian imperialism survived only through sheer violence and suppression. Prior to Grote, historians made it their business to attack Athenian democracy, and through that, democracy in general. Mitford and Gillies, the most famous historians before Grote, wrote with the French Revolution in their minds. Democracy was equated with mob rule and terror. The rule of the demos was considered anarchical and the rule of envy and passion. Democracy ignored the ranks of society: it meant conflict between the lower and upper classes. Grote differed from previous historians of Greece in that he approached

${ }^{5}$ W.Smith, "George Grote", Quarterly Review, 135(1873):130, emphasis added. 
his subject unaffected by their conservatism. His disposition to view the Greeks, and especially the Athenians, in a liberal spirit, contributed to the consistency and accuracy of his narrative. In this respect, his greatest achievement was his defence of democracy, where it had suffered under the biased opinions of his predecessors.

As the historian of Athens, Grote brought to light much that was new. His presentation of the Athenian people, the origin, growth and culmination of their civilization and political morality, forms one of the most original and fascinating portions of his narrative. He defended Athenian democracy against the various misrepresentations to which it had been subjected for more than two thousand years; and he argued that Athenian democracy respected individual life, preserved and guaranteed private property, and administered justice impartially.

At the time, Grote's arguments appeared paradoxical to some scholars. He was the first historian to defend ostracism, insisting on its use to cultivate, what he called, 'constitutional morality'. Instead of reproaching the ambitious foreign policy of Athens, as was conventionally done, he became the champion of its maritime empire, dwelling on its practical advantages and associating with it the fate of Greek civilization. Instead of sharing the common belief in the intrinsic baseness of demagogic activity, he linked it with the development of democratic consciousness itself, and drew the analogy between the demagogue of ancient times and the opposition leader of the nineteenth century. The demagogue was regarded as champion of the people against the interests of the aristocratic party in the state. In his role he often brought political offenders to justice, and kept a strong check upon the holders of important offices. Instead of acquiescing in the long-established account of Athenian political life driven by dark conspiracies, and the Athenian character filled 
with envy and uncontrolled passions, Grote argued that the Athenians were attached to the forms of their constitution. Rather than praise the mixed, steady, Spartan constitution, he saw in it a deficient and unattractive form of government. He did not praise Spartan patriotism, but, on the contrary, called the Spartans the most isolated of nations, the most aggressive, vicious, and self-indulgent. In the sophistic teaching he did not discern any corrupt purpose, but practical and useful instruction tending to promote mutual respect and toleration. The sophists were a number of celebrated professors highly respected in their era.

Grote first understood Socrates as not antagonistic to the sophists. Their method of discussion was much the same; and most importantly they recognized the relative value of Goodness. They differed to the extent that the sophists harmonized their teachings with current ethical and political conventions, while Socrates questioned these conventions. Though Grote did not deny that there was a certain amount of scepticism in sophistic culture, their scepticism was a reflection of the age. Socrates' role was treated by Grote as a continuation of the sophistic humanism. Socrates concentrated more on the individual, rather than on society, and he thus prepared the way for a science of ethics. But both, Socrates and the sophists, shared the same tendency, namely, to emancipate the individual. They tried to do this by teaching him to participate in public life and to exercise his independent judgement. Grote developed Schleiermacher's view that Socrates' worth as a philosopher consisted in his method and not in any positive teaching.

Plato was approached by Grote as a philosopher of outstanding originality but also as a person dissenting from the established ethical, cultural and political sentiment. In the Plato and the other Companions of Sokrates, written in the $1860 \mathrm{~s}$, 
Grote criticized Plato for harshly curtailing individual liberty, and sacrificing it to the abstraction called the state. J.S.Mill's On Liberty made a deep impression on Grote. Thus Plato's disregard of the value of individual freedom was much stressed in his Plato. Like Mill, Grote believed in the liberty of individual judgement, however right or wrong. He believed in its intrinsic value per se. In the negative dialogues he praised Plato for the emphasis he placed on the exercise of personal judgement. But he also saw in the same philosopher how philosophical dogmatism could lead to impracticable theoretical models of political organisation. On the other side, in the pnyx and the agora of Athens, Grote visualized a magnificent spectacle. Each citizen had the right to judge, to opine, to disagree. He saw Pericles pronouncing that political life was the legitimate area of personal participation, mutual respect and individual responsibility. It was the democratic liberties which fostered the brilliant Athenian culture and made Athens the spiritual centre of ancient Hellenism.

Contemporary scholars attacked Grote usually on the ground of what they regarded his 'philosophic inappropriateness'. Grote understood nothing of Plato's lofty Idealism, and his supposed hostility to him was considered the result of his inability to do so. Plato, as John Owen argued, was unsuited to Grote's 'type of mind'. 6 This sort of criticism was true to the extent that Grote did not attempt to catch Plato's elevated and transcendental spirit. His foremost intention was to appreciate Plato's contribution to the science of 'reasoned truth', as he called philosophy.

${ }^{6}$ J.Owen, "George Grote", Theological Review, 10(1873):516. Plato, stated Jowett, "is not to be measured by the standard of Utilitarianism" (The Dialogues of Plato, Oxford 1892, vol. I, p. x). See also, E.Caird, "Plato and the other companions of Socrates", North British Review, 43(1865):354; L.Campbell, "Grote's Plato", Quarterly Review, 119(1866):125, and The 'Theatetus' of Plato, Oxford 1883, p. viii; Thomas Maguire, Essays on the Platonic Ethics, London, Oxford and Cambridge, 1870, pp. iii, 1, 34. 
When comparing Platonic studies, as they existed prior to Grote's work, with his achievement, one cannot fail to recognize why Grote conceived of his works in terms of a defence of Platonic philosophy. Plato's philosophy was not an object of analytical study in the British universities before the 1850s. Thomas Taylor's interpretation of Plato's dialogues, a typical example of Platonic analysis, appealed to the Romantics. For Taylor, the name of Plato suggested a mystical way of thinking. Unlike Taylor, who appreciated this thinking, other scholars in his day attacked Plato on the grounds of his paganism. Plato distorted, in their view, the authentic Socratic teaching by introducing into it Pythagorean doctrines. Socrates was treated almost as an apologist for Christian ethics. The underlying purpose of these scholars was to discredit the argument that Plato anticipated some fundamental Christian principles. Grote set out to emphasize the prevalence of reason in Plato's philosophy. In Grote the character of Plato is seen, as another utilitarian contended, "in its true proportions, as well as in its vast dimensions".' Grote originated 'scientific' Platonic analysis: Plato became better understood when he stopped being treated as the "surnamed divine". ${ }^{8}$ Modern Platonic studies in Britain started with Grote.

Grote rejected the standard German interpretation which converted the Platonic dialogues into a model of theoretical perfection. Internal evidence, Grote believed, was too weak to support such a reconstructive scheme. Plato was an unmatched dramatist, an exceptional poet, a rare philosophic genius, a rhetor and a theologian. His intellectual character being many-sided, it appears to be hardly susceptible to philosophic systematization. Each dialogue was attached to a different plan and scope.

\footnotetext{
${ }^{7}$ A.Bain, "Grote's Plato", Macmillan's Magazine, 12(1865):472.

${ }^{8}$ M.E.A.Girot, La Morale Des Anciens, London 1807, p. 340, my translation.
} 
Such a diversity of plan warranted the argument that an approach which dealt with each dialogue as a complete work might be of more assistance in understanding Plato. Grote did not think it correct to reject a dialogue because it was inferior in subject, style or structure. No one was justified in setting such high standards for a philosopher. To speak about Plato's System der Philosophie, to put forward dogmatic statements regarding Platonic thought, involved the danger of one-sidedness. And Plato, in Grote's estimation, was far from being one-sided.

Grote became an authority regarding the sophists and Socrates. But even here the position of Plato in Grote's interpretation was not one of uncritical rejection. Later generations connected the name of the sophists with the contempt shown them by Plato, but Plato himself, Grote argued, showed respect for famous figures like Protagoras and Gorgias. On the other hand, though the Athenians had sufficient reasons to condemn Socrates, Grote would side with him, rather than with his accusers. If the Athenians appeared in the light of an historical analysis to have plausible reasons in putting Socrates to death, Plato had his own good reasons to write his encomium. Grote protested against the tendency to look only at one side of the case.

J.S.Mill evidently admired Plato but he would not place in jeopardy his advocacy of individual liberty to do so. Similarly, Grote admired Plato but he would not compromise his defence of the liberal state, whose prototype he saw in Athenian democracy. Grote felt that Plato offered lessons which, even if put forward in his dogmatic pieces, might be useful in modern philosophic debates and practical political life. Grote firmly believed that Plato was not a democrat: but he never said that from a non-democratic philosopher, especially when one is speaking of Plato, no positive 
political lessons can be extracted. Plato's ideal polis fortunately survived only as a utopian dream: 'there is nothing to makes us regret that Plato was never able to carry out his ideal', Grote maintained: but he gave us to understand that there should have been considerable regrets if Plato had never been in a position to develop his theory.

In conclusion, Grote inaugurated a new era of Platonic criticism. And this he did in many ways. It would be wrong to number Grote's name among scholars unfriendly to Plato. Grote admired Plato for his positive contribution to the growth of philosophic thought. Plato developed political philosophy as a separate branch of knowledge. But the most important aspect of Grote's contribution consisted in his treatment of Plato not as a 'divine' abstracted from the realities of fifth and fourth century Athenian political and intellectual life. Grote called attention to the historical factor in Plato's writings. Plato lived in times when Socrates wandered in the dirty streets of Athens pursuing his mission. He lived in the culmination of the sophistic period and the Greek Enlightenment. Grote facilitated our understanding of Socrates and the sophists, shed light on their relationship, and explained to us Plato's treatment of them. Lastly, Grote made it easier to understand that a perfectionist view of Plato's potential might not be the best instrument for one who aspires to appreciate the worth of his philosophy. 


\section{BIBLIOGRAPHY}

\section{I Manuscripts and works of George Grote}

"Early Exercises at Charterhouse, at about the age of eleven or twelve - 1805-1806", University of London Library (Senate House), MSS 429/1, 1805-1806.

Notes of Various Studies, University of London Library (Senate House), MSS 429/2, 1816. MSS 429/3, 1817. MSS 429/4, 1820.

"Notes Relating to Grecian History, etc", [B]ritish [L]ibrary Additional MS 29,514 (1818-1831).

"Notes Relating to Grecian History", BL Add. MS 29,515 (1818-1824).

"Notes Relating to Grecian History", BL Add. MS 29,516 (1828 \& 1840-1850).

"Notes Relating to Grecian History etc. Newspaper Cuttings on the Ballot", BL Add. MS 29,517 (1826-1832 \& 1833).

"Notes Relating to Grecian history", BL Add. MS 29,518 (1824-1840).

"History of Greece. Colonies", BL Add. MS 29,519 (1824-1831).

"Notes Relating to Grecian History. Athenian Government etc.", BL Add. MS 29,520 (1815-1851).

"Notes on Ancient History", BL Add. MS 29,521 (prior to 1832).

"Digest of the Dialogues of Plato. The character of Socrates", BL Add. MS 29,522 (prior to 1832).

"Religion of the Ancient World", BL Add. MS 29,523 (prior to 1826).

"Essays on Works of Cicero and Lucretius", BL Add. MS 29,525 (1815-17).

"Logical and Metaphysical Essays", BL Add. MS 29,528 (1818).

"Essays and Notes on Various Subjects", BL Add. MS 29,529 (1818-1822).

"Essay on Magick" BL Add. MS 29,531 (1820).

Correspondence with J.Bentham, BL Add. MS 33,546 (1824-1847), fos. 55, 60, 165-6, 371-2. 
An Analysis of the Influence of Natural Religion on the Temporal Happiness of Mankind, ed. by G.Grote under the pseud. Philip Beauchamp, Carlile, London, 1822.

"Fasti Hellinici. The Civil and Literary Chronology of Greece, from the 55th to the 124th Olympiad", Westminster Review, 5(1826):264-331.

"Grecian Legends and Early History", first published in Westminster Review, 1843. Reprinted in Minor Works, pp.75-134.

Essentials of Parliamentary Reform (1831), Minor Works, pp.1-55.

$$
\text { (first edn, } 1846-54 \text { ) }
$$

A History of Greece, 6th edn, (10 vols.), John Murray, London 1888.

Plato and the other Companions of Sokrates (3 vols.), Murray, 1865.

Poems by George Grote, 1815-1823, ed. by Harriet Grote, printed for private circulation, Savill, Edwards and co., London, 1872.

Minor Works, ed. by A.Bain, Murray, London, 1873.

Posthumous Papers, ed. by H.Grote, printed for private circulation, William Clowes and sons, London, 1874.

Fragments on Ethical Subjects, ed. by A.Bain, Murray, London, 1876.

II

\section{General Bibliography}

Ackermann, C. The Christian Element in Plato and the Platonic Philosophy, trans. by Samuel R.Asbury, Edinburgh (T. \& T. Clark), London (Hamilton, Adams, and co.), 1861.

Adamson, Robert. The Development of Greek Philosophy, ed. by W.R.Sorley and R.P.Hardie, William Blackwood and Sons, Edinburgh and London, 1908.

Aelian. Various History, text in Greek, ed. M.R.Dilts, Teubner (Bibliotheca scriptorum...) Leipzig, 1974.

Aeschines. The Speeches of Aeschines, trans. C.D.Adams, Loeb Classical Library, Harvard University Press, Cambridge, Mass., 1919.

Agard, W.R. What Democracy Meant to the Greeks, University of Wisconsin Press, Madison, 1960.

Andrewes, A. "The Arginousai Trial", Phoenix, 28(1974):112-22. 
Annas, Julia. An Introduction to Plato's Republic, Clarendon Press, Oxford, 1981.

Anonymous. Critical Inquiry into the Opinions and Practice of the Ancient Philosophers, concerning the Nature of the soul and a Future State, And their Method of teaching by the DOUBLE DOCTRINE, London, 1745.

Phedon: or, a Dialogue of the Immortality of the Soul. From Plato the Divine Philosopher, London, 1777.

An Essay on the Character and Doctrines of Socrates, Slatter and Munday, Oxford, 1802.

(2). "Grote's History of Greece", Tait's Edinburgh Magazine, 13(1846):375-380.

(4). "Grote's History of Greece", Eclectic Review, 20(1846):257-280.

-----(1). "Grote's History of Greece", Eclectic Review, 22(1847):289-299.

(3). "Grote's Greece", New York Quarterly, 3(1854):106-123.

(6). "Grote's History of Greece", Putnam's Monthly Magazine of American Literature, Science, and Art, 8(1856):179-188.

------(5). "Greek History", London Quarterly Review, 28(1867):1-44.

------.. "Jowett's Plato", London Quarterly Review, 37(1871):79-117.

------.. "The Study of Plato", Macmillan's Magazine, 24(1871):81-87.

-.---. "Life of George Grote", Christian Observer, 73(1873):633-639.

Anster, John. "Grote's History of Greece" (I), Dublin University Magazine, 35(1850):477-490 (review of vols 1-8).

------.. "Grote's Greece" (II), Dublin University Magazine, 45(1855):477-490 (review of vol.12)

Anton, Peter. Masters in History, Gibbon-Grote-Macaulay-Motley, Macniven and Wallace, Edinburgh, 1880.

Aristophanes. Comedies (3 vols.), trans. B.B.Rogers, Loeb Classical Library, Harvard University Press, Cambridge, Mass., 1924.

Aristotle. De Anima, trans. R.D.Hicks, Cambridge University Press, Cambridge, 1907.

-------. Politics, trans. H.Rackham, Loeb Classical Library, 1926. 
-.---.. Nicomachean Ethics, trans. H.Rackham, Loeb Classical Library, 1926.

-.---... On Sophistical Refutations, trans. E.S.Forster, Loeb Classical Library, 1955.

---.-. Rhetorics, trans. J.H.Freese, Loeb Classical Library, 1926.

-------. Physics, trans. F.M.Cornford, Loeb Classical Library, 1929.

-------. The Athenian Constitution, trans. H.Rackham, Loeb Classical Library, 1935.

-.-.-.-. Magna Moralia, trans. G.C.Armstrong, Loeb Classical Library, 1935.

Ast, Friedrich. Platon's Leben und Schriften, Leipzig, 1816.

-------. Lexicon Platonicum, 3 vols, Lipsiae, 1835-8.

Badham, Platonis Philebus, London, 1855.

Bain, Alexander. "Grote's Plato. The negative, or Search Dialogues", Macmillan's Magazine, 12(1865):193-208.

-------. "Grote's Plato. The affirmative, or Exposition Dialogues", Macmillan's Magazine, 12(1865):457-472.

--------. "On Early Philosophy", Macmillan's Magazine, 14(1866):148-160.

-------. James Mill. A Biography, Longmans, Green \& co., London 1882.

------. John Stuart Mill, Longmans, Green \& co., London 1882.

Barrett, Harold. The Sophists, Rhetoric, Democracy, and Plato's Idea of Sophistry, Chandler \& Sharp Publishers, Inc., California, 1987.

Bauman, A. Political Trials in Ancient Greece, Routledge, London and New York, 1990.

Benn, A.W. "The Place of Socrates in Greek Philosophy", Westminster Review, 114(1880):19-62.

-------. "Plato and his Times", Westminster Review, 114(1880):389-419.

--------. The Philosophy of Greece, London, 1898.

---1--.-. The History of English Rationalism in the Nineteenth Century, vol.I, Longmans, Green \& co., London, 1906.

Bentham, J. An Introduction to the Principles of Morals and Legislation, ed. by 
J.H.Burns and H.L.A.Hart, London, 1970.

Constitutional Code, vol.I, ed. by F.Rosen and J.H.Burns, Oxford, 1983.

Deontology, ed. by Ammon Goldworth, Clarendon Press, Oxford, 1983.

A Fragment on Government, Cambridge University Press, Cambridge, 1988.

Bernal, Martin. Black Athena, The Afroasiatic Roots of Classical Civilization, vol.I, Free Association Books, London, 1987.

Blackie, J.S. "Plato", in Edinburgh Essays for 1856, Adam and Charles Black, Edinburgh, 1857, pp.1-41.

-.----. "Plato and Christianity", North British Review, 35(1861):360-385.

-------. Four Phases of Morals. Socrates, Aristotle, Christianity, Utilitarianism, Edmonston and Douglas, Edinburgh, 1871.

------. Horae Hellenicae: Essays and Discussions on some important points of Greek philology and Antiquity, Macmillan, London, 1874.

Blackley, W.L. "The authenticity of the works of Plato", Fortnightly Review, 2(1867):272-86.

Blakey, Robert. Historical Sketch of Logic, from the earliest times to the present day, Edinburgh (James Nichol), London (H.Bailliere), Glasgow (Griffin \& co.), 1851.

Bleckly, Henry. Socrates and the Athenians, Kegal Paul, Trench \& co., London, 1884.

Boase, G.C. "Norman, George Warde (1793-1882)", [D]ictionary of [N]ational [B] iography, vol.XLI, London 1895, pp.112-113.

Boeckh, Augustus. The Public Economy of the Athenians, second edn, trans. by Anthony Lamb, Sampson Low, son and co., London, 1857.

Bonitz, Hermann. Geschichte und System der Platonischen Philosophie, Heidelberg, 1839.

-----.. Platonische Studien, Wien, 1858.

Bonner, R. Lawyers and Litigants in Ancient Athens, University of Chicago Press, Chicago, Illinois, 1927.

Bonner, R.J. Aspects of Athenian Democracy, University of California Press, Berkeley, California, 1933. 
Borchard, R. (ed.), Four Dialogues of Plato, trans. with notes by J.S.Mill, Watts \& co., London, 1946.

Bower, G.S. Hartley and James Mill, Sampson Low, Marston, Searle, \& Rivington, London, 1881.

Bowra, C.M. Periclean Athens, History Book Club, London, 1971.

Brandis, C.A. "Plato", in W.Smith (ed.), Dictionary of Greek and Roman Biography and Mythology, vol.III, John Murray, London, 1859.

Brickhouse, T.C. and Smith, N. Socrates on Trial, Clarendon Press, Oxford, 1989.

Brucker, J.J. The History of Philosophy from the Earliest Times to the beginning of the present century (trans. and abridged from the Historia Critica Philosophiae, Leipzig, 1724-67 - 6 vols., by W.Enfield), J.F.Dove, London, 1819.

Bryant, Jacob. A New System, or, an Analysis of Ancient Mythology (2 vols.), London, 1774.

A Treatise upon the Authenticity of the Scriptures, and the Truth of the Christian Religion, 3rd edn, London, Edinburgh, Glasgow and Dublin, 1810.

Bulwer, E.L. Athens. Its Rise and Fall (2 vols.), Saunders and Otley, London, 1837.

Burn, A.R. Pericles and Athens, Hodder \& Stoughton Ltd., London, 1948.

Burns, J.H. "J.S.Mill and Democracy, 1829-61" (I), Political Studies, 5(1957):158-175.

--------. "Bentham and the French Revolution", Transactions of the Royal Historical Society, 5th ser., 16(1966): $95 \div 114$.

Burston, W.H. James Mill on Education, Cambridge University Press, Cambridge, 1969.

Bury, J.B. A History of Greece to the death of Alexander the Great, Macmillan, London, 1904.

Butler, W.A. Lectures on the History of Ancient Philosophy (2 vols.), ed. by W.H.Thompson, Macmillan, Cambridge, 1856.

Caird, Edward. "Plato and the other companions of Socrates", North British Review, 43(1865):351-84.

-------. The Evolution of Theology in the Greek Philosophers, vol.I, James MacLehose and Sons, Glasgow, 1904. 
Calder, W.M. (ed.) The Cambridge Ritualists Reconsidered, Atlanta, 1992. (Includes Grote's 'Essay on Magic').

Campbell, Lewís. "The Platonic Dialogues", Quarterly Review, 112(1862):306-347. "Grote's Plato", Quarterly Review, 119(1866):108-53.

The 'Theaetetus' of Plato, Oxford, 1861.

--------. "Plato", Encyclopaedia Britannica, eleventh edn, vol.XXI, Cambridge University Press, Cambridge, 1911, pp.808-812.

Carlyle, E.I. "Young, Sir William", D.N.B., vol.LXIII, Smith, Elders, \& co., London, 1900, pp.399-400.

------. "Sydenham, Floyer", D.N.B., vol.LX, London, 1898, p.245.

Carter, L.B. The Quiet Athenian, Clarendon Press, Oxford, 1986.

Cary, Henry. (ed.), The Works of Plato, vol.I, Henry G.Bohn, London, 1848.

Champlin, James Tift. "Grote's Greece", Christian Review, 16(1851):481-505.

Chatterton, Georgiana (Lady). Selections from the works of Plato, Richard Bentley, London, 1862.

Chroust, Anton-Hermann. "The Organization of the Corpus Platonicum in Antiquity", Hermes, 93(1965):34-46.

Churton, W.R. "Athens in the time of Pericles, and Rome in the time of Augustus", The Oxford English Prize Essays, vol.IV, D.A.Talboys, Oxford, 1830, pp.79-131.

Cicero. Republic, trans. C.W.Keyes, Loeb Classical Library, Harvard University Press, Cambridge, Mass., 1935.

Academics, trans. H.Rackham, Loeb Classical Library, 1929.

Clarke, M.L. Greek Studies in England: 1700-1830, Cambridge University Press, Cambridge, 1945.

------. George Grote: A Biography, The Athlone Press, London, 1962.

Claster, J.N. (ed.), Athenian Democracy: Triumph or Travesty? Robert E.Krieger Publishing Company, Huntington, N.Y., 1978.

$$
\text { ii. F. }
$$

Clinton, Fasti Hellenici. The Civil and Literary Chronology of Greece from the Earliest Accounts to the Death of Augustus (3 vols), Oxford, 1824. 
Collins, C.W. Plato, William Blackwood and Sons, Edinburgh and London, 1874.

Connor, W.R. The New Politicians of Fifth-Century Athens, Princeton University Press, Princeton, 1971.

Cooper, J.G. The Life of Socrates, 4th edn, J.Dodsley, London, 1771.

Cope, E.M. "The Sophists", The Journal of Classical and Sacred Philology, 1(1854):145-188.

------.. Plato's 'Theaetetus' and Mr Grote's criticisms, Cambridge (Deighton, Bell, and co.), London (Bell and Daldy), 1866.

Cousin, V. Introduction to the History of Philosophy, trans. by H.G.Linberg, Hilliard, Gray, Little, and Wilkins, Boston, 1832.

Cox, George William. A History of Greece (2 vols.), Longmans, Green, and Co., London, 1874.

--------. The Athenian Empire, 6th edn, Longmans, Green, and Co., London, 1888.

-------. Lives of Greek Statesmen, Harper and Brothers, New York, 1886.

Cramer, J.A. A Geographical and Historical Description of Ancient Greece, (3 vols.), vol.II, Clarendon Press, Oxford, 1828.

Croiset, Maurice. Aristophanes and the Political Parties at Athens, trans. by James Loeb, Macmillan, London, 1909.

Croix, G.E.M. de Ste. "The Character of the Athenian Empire", Historia, 3(1954):141.

Cross, R.N. Socrates, the man and his mission, Methuen, London, 1914.

Cross, R.C. and Woozley, A.D. Plato's Republic. A Philosophical Commentary, London (Macmillan), N.Y. (St Martin's Press), 1966.

Cumming, Ian. "The Scottish Education of James Mill", History of Education Quarterly, 2(1962):152-167.

-.---. "Enemies to wonder: James Mill and the Diffusionists", Paedagogica Historica, 2(1971):351-368.

Curtius, Ernst. The History of Greece, trans. by A.W.Ward, first German edn 1865, Charles Scribner's Sons, New York, 1892.

Dacier, A. Plato's Divine Dialogues, together with the Apology of Socrates, 5th edn, 
S.Cornish \& co., London, 1839.

Davidson, W.L. Political Thought in England, Williams and Norgate, London, 1915.

Davies, J. "George Grote", Contemporary Review, 22(1873):393-411.

Davies, J.K. Democracy and Classical Greece, Collins, Fontana, 1978.

Davies, J.L. and Vaughan, D.J. The Republic of Plato, Macmillan, London, 1925 (3rd edn, 1866).

Davies, Roger. An Essay in the Socratick Way of Dialogue, on the Existence of a Divine Being, London, 1724.

Demosthenes. Against Timocrates, trans. J.H.Vince, Loeb Classical Library, 1935.

Diodorus. The Library of History, trans. C.H.Oldfather, Loeb Classical Library, 193345.

Diogenes Laertius. Lives of Eminent Philosophers, trans. R.D.Hicks (2 vols), Loeb Classical Library, 1925.

Dodds, E.R. The Greeks and the Irrational, California University Press, California, 1951.

---.-.-. "The Sophistic Movement and the Failure of Greek Liberalism", in The Ancient Concept of Progress and other Essays on Greek Literature and Belief, Clarendon Press, Oxford, 1973.

Donne, W.B. "Grote on Alexander the Great", National Review, 3(1856):50-80.

Drummond, William. A Review of the Governments of Sparta and Athens, W.Bulwer and co., London, 1794.

Dunn, M. "Iamblichus, Thrasyllus, and the Reading Order of the Platonic Dialogues", in R.B.Harris (ed.), The Significance of Neo-Platonism, International Society of NeoPlatonic Studies, Old Dominion University, Norfolk, Virginia, 1976, pp.59-80.

Duruy, Victor. History of Greece (4 vols.), Kegal Paul, Trench, Trubner \& co., London, 1892.

Eastlake, Lady. Mrs Grote. A Sketch, John Murray, London, 1880.

Edelstein, L. Plato's Seventh Letter, Leiden, 1966.

Edwards, B.B. and Park, E.A. (ed.), Selections from German Literature, Gould, Newman and Saxton, Andover and New York, 1839. 
Edwards, E. (?) The Socratic System of Morals, as delivered in Xenophon's 'Memorabilia', London, 1773.

Ehrenberg, Victor. The Greek State, Basil Blackwell, Oxford, 1960.

From Solon to Socrates, 2nd edn (first edn 1967), Methuen, London, 1973.

Emerson, G.H. "Grote's History of Greece", The Universalist Quarterly and General Review, 14(1857):54-65.

Emerson, R.W. Two Unpublished Essays. The Character of Socrates. The Present State of Ethical Philosophy, ed. by E.E.Hale, Boston and New York, 1895.

Erdmann, Johann Eduard. A History of Philosophy, trans. from the 3rd German edn (first edn 1865) by W.S.Hough (3 vols.), London (Swan Sonneschein \& co.), N.Y. (Macmillan), 1893.

Farrar, C. The Origins of Democratic Thinking, Cambridge University Press, Cambridge, 1988.

Felton, Cornelius Conway. "Grote's History of Greece", Christian Examiner and Religious Miscellany, 48(1850):292-301.

-----. Greece, Ancient and Modern, vol.II, Ticknor and Fields, Boston, 1867.

Fenn, R.A. James Mill's Political Thought, Garland Publishing, Inc., New York and London, 1987.

Ferguson, W.S. Greek Imperialism, London (Constable \& co.), Boston and N.Y. (Houghton Mifflin Co.), 1913.

Ferrier, J.F. Lectures on Greek Philosophy and other Philosophical Remains of James Frederick Ferrier, ed. by A.Grant and E.L.Lushington, vol.I, William Blackwood and sons, Edinburgh and London, 1866.

Finley, M.I. "Athenian Demagogues", Past and Present, 21(1962):3-24.

Aspects of Antiquity, Chatto \& Windus, London, 1968.

Fite, Warner. The Platonic Legend, Charles Scribner's Sons, New York and London, 1934.

Forchhammer, P.W. Die Athener und Sokrates, Berlin, 1837.

Forrest, W.G. A History of Sparta 950-192 BC, Hutchinson University Library, London, 1968. 
Forster, John. "Socrates and the Sophists of Athens", Foreign Quarterly Review, 30(1843):331-368.

-------. "The Dialogues of Plato", Foreign Quarterly Review, 31(1843):471-501.

Foster, M. "Grote's History of Greece", London Quarterly Review, 7(1856):51-71.

Fowler, W.Warde. The City-States of the Greeks and Romans, 2nd edn (first edn 1893), Macmillan, London, 1895.

Freeman, E.A. "A History of Greece", North British Review, 25(1856):141-172.

-...-.... Historical Essays, second ser., 3rd edn, Macmillan, London, 1889.

Fronthingham, N.L. "Grote's History of Greece", Christian Examiner and Religious Miscellany, 62(1857):55-73.

Frost, F.J. (ed.), Democracy and the Athenians, John Wiley and sons, Inc., N.Y., London, Sydney, Toronto, 1969.

Garforth, F.W. Educative Democracy, John Stuart Mill on Education in Society, O.U.P., Oxford, 1980.

Geddes, James. An Essay on the Composition and Manner of Writing of the Antients, particularly Plato, Robert Foulis, Glasgow, 1748.

Gibbon, E. The Decline and Fall of the Roman Empire (4vols.), Gibbings and Company, Ltd., London, 1895.

Gifford, Edwin Hamilton. (trans.), The 'Euthydemus' of Plato, Clarendon Press, Oxford, 1905.

Gillies, John. The Orations of Lysias and Isocrates, trans. with notes, J.Murray, London, 1778.

-.-.-.. History of Ancient Greece, 3rd edn (4 vols.), Strahan \& T.Cadell, London, 1792.

Girot, M.E.A. La Morale Des Anciens, Cox, Fils, et Baylis, London, 1807.

Glover, T.R. Democracy in the Ancient World, Cambridge University Press, Cambridge, 1927.

Godley, A.D. Socrates and Athenian society in his day. A Biographical Sketch, Seeley and co., Ltd., London, 1896.

Goldsmith, Oliver. The Grecian History, from the earliest state to the Death of 
Alexander the Great (2 vols.), London, 1774.

Gomme, A.W. "The Working of the Athenian Democracy", in More Essays in Greek History and Literature, Basil Blackwell, Oxford, 1962, pp.177-193.

Gomperz, Theodor. Greek Thinkers, vols I, II and III, trans. by Laurie Magnus and G.G.Berry, John Murray, London, 1901-1905.

Goodwin, William Watson. "Grote's Greece", North American Review, 78(1854):151-

Gough, J.W. The Social Contract, Clarendon Press, Oxford, 1936.

Goulburn, Edward Meyrick. Socrates. A LECTURE delivered to the Young Men's Christian Association, Gilbert \& Rivington, London, 1858.

Grant, Alexander. The Ethics of Aristotle, vol.I, fourth edn, Longmans, Green and co., London, 1885.

Greene, G.W. "Reminiscences of George Grote", Atlantic Monthly, 44(1879):770-774.

Greene, W.C. "Platonism and its Critics", Harvard Studies in Classical Philology, 61(1953):39-71.

Griffiths, E.T. Plato, as read in English by an Englishman; being an address to some friends, John Chapman, London, 1854.

Grote, Harriet, The Philosophical Radicals of 1832, published for private circulation, Savill and Edwards, London, 1866.

The Personal Life of George Grote, J.Murray, London, 1873.

Grote, John. A few remarks on a pamphlet by Mr. Shilleto entitled 'Thucydides or Grote?', Deighton, Cambridge and London, 1851.

Grube, G.M.A. "The Cleitophon of Plato", Classical Philology, 26(1930):302-308.

Gunn, W.M. "Gods and Heroes of Legendary Greece", Classical Museum, 5(1848):125-170.

Guthrie, W.K.C. A History of Greek Philosophy, vols III-V, C.U.P., Cambridge, 19691978.

Socrates, Cambridge University Press, Cambridge, 1971.

The Sophists, Cambridge University Press, Cambridge, 1971.

Hackforth, M.A. "Hedonism in Plato's Protagoras", Classical Quarterly, 22(1928):39- 
42.

------.. "Great Thinkers (i) Socrates", Philosophy, 8(1933):259-272.

Halevy, Elie. The Growth of Philosophic Radicalism, Faber \& Faber, London, 1934.

Hampden, Renn Dickson. The Fathers of Greek Philosophy, Adam and Charles Black, Edinburgh, 1862.

Hare, R.M. Plato, Oxford University Press, Oxford 1982.

Hare, Thomas. "The Personal Life of George Grote", Westminster Review, 100(1873):129-172.

Hathaway, R.F. "The Neoplatonic Interpretation of Plato", Journal of the History of Philosophy, 7(1969):20-22.

Headlam, J.W. Election by lot at Athens, Cambridge University Press, Cambridge, 1891.

Healey, T. "The Socrates of the Athenian people", Cornhill Magazine, 9(1964):576584.

Heeren, A.H.L. A Manual of Ancient History, D.A.Talboys, Oxford, 1829.

-.-.-.. A Sketch of the Political History of Ancient Greece, D.A. Talboys, Oxford, 1834.

Hegel, F. Lectures on the History of Philosophy, trans. by E.S.Haldane and F.H.Simson, Routledge \& Kegan Paul, vols I \& II, London, 1892-94.

Heidel, W.A. Pseudo-Platonica, Baltimore, 1896.

Hermann, K.F. Geschichte und System der Platonischen Philosophie, Heidelberg, 1839.

Herodotus. History, trans. A.D.Godley, Loeb Classical Library, Harvard University Press, Cambridge, Mass., 1920.

Hignett, C. A History of the Athenian Constitution to the end of the fifth century B.C., Clarendon Press, Oxford, 1952.

Hobbes, T. Thucydides in English, Munday and Slatter, Oxford, 1824.

Hoerber, R.G. "Thrasyllus' Platonic Canon and the Double Titles", Phronesis, 2(1956):10-20. 
Holm, Adolf. The History of Greece from its commencement to the close of the independence of the Greek Nation (4 vols.), Macmillan, N.Y. and London, 1902.

Horne, Thomas Hartwell. The Deaths of Socrates and of Jesus Christ contrasted, J.M.Robeson, London, 1852.

Hume, David. History of England, vol.I, London, Thomas Dodby, 1825.

Hyslop, J.H. The Ethics of the Greek Philosophers. Socrates, Plato and Aristotle, Charles M.Higgins \& co., New York, Chicago and London, 1903.

Iggers, G.G. and Powell, J.M. (ed.), Leopold von Ranke and the Shaping of the Historical Discipline, Syracuse University Press, Syracuse, New York, 1990.

Irwin, Terence. Plato's Moral Theory, Clarendon Press, Oxford, 1977.

Isocrates. Panegyricus, On the Peace, Areopagiticus, trans. George Norlin, Loeb Classical Library, 1928-9.

Jackson, John. The Belief of a Future state proved to be a Fundamental Ariticle of the Religion of the Hebrews. And the Doctrine of the ancient Philosophers concerning a Future state, shewn to be consistent with Reason, London, 1745.

A Farther Defence of the Ancient Philosophers, London, 1747.

Jenkyns, Richard. The Victorians and Ancient Greece, Basil Blackwell, Oxford, 1980.

Jevons, Frank Byron. A History of Greek Literature: from the Earliest period to the Death of Demosthenes, Charles Griffin and co., London, 1886.

The Development of the Athenian Democracy, London (Griffin \& co.), Durham (T.Caldcleugh), 1886.

Jones, A.H.M. "The Athenian Democracy and its Critics", in Athenian Democracy, Blackwell, Oxford, 1957, pp.41-72.

Jowett, B. The Dialogues of Plato, vol.I, 3rd edn, Oxford University Press, Oxford, 1892.

------. The Dialogues of Plato, vol.III, fourth edn, Clarendon Press, Oxford, 1953.

Jubert, Leo. "Plato et l' ecole Socratique devant la critique moderne", Revue Contemporaine, XLVIII (1865):601-629.

Kagan, Donald. "The Origin and Purposes of Ostracism", Hesperia 30(1961):393-400.

-.--.-.. The Fall of the Athenian Empire, Cornell University Press, Ithaca and London, 
1987.

Kahn, C.H. "The Origins of Social Contract Theory", in Kerferd (ed.) The Sophists and their Legacy, Wiesbaden, 1981, Franz Steiner Verlag Gmbhpp.92-108.

Karavites, Peter. "Cleisthenes and Ostracism Again", Athenaeum, 52(1974):326-36.

Kerferd, G.B The Sophistic Movement, Cambridge University Press, Cambridge, 1981.

Kingdon, G.T. An Essay on the 'Protagoras' of Plato in which a reply is furnished to some modern critics, Cambridge (Deighton, Bell, and co.), London (George Bell and Sons), 1875.

Knight, William. Lord Monboddo and some of his contemporaries, John Murray, London, 1900.

Kraut, Richard. Socrates and the State, Princeton University Press, Princeton, New Jersey, 1984.

Langlois, C.V. and Seignobos, C. Introduction to the Study of History, trans. by G.G.Berry, Duckworth, London, 1898.

Leigh, Aston. The Story of Philosophy, Trubner \& co., London, 1881.

Levi, A.W. "The idea of Socrates: the philosophic hero in the nineteenth century", Journal of the History of Ideas, 17(1956):89-108.

Lewes, George Henry. A Biographical History of Philosophy (2 vols.), Charles Knight and co., London, 1845.

----.-. "Grote's History of Greece", Westminster Review, 46(1847):381-415.

--------. "Mr Grote's Plato", The Fortnightly Review, 2(1865):169-83.

-------. The History of Philosophy from Thales to Comte, vol.I, Longmans, London, 1871.

Lewin, Thomas Herbert. (ed.), The Lewin Letters. A Selection from the correspondence and diaries of an English family, 1756-1884 (2 vols.), printed for private circulation, Archibald Constable \& co. Ltd., London, 1909.

Lewis, George Cornewall. "Mythology and Religion of Ancient Greece", Foreign Quarterly Review, 7(1831):33-52.

\footnotetext{
--------. "Grote's History of Greece" (I), Edinburgh Review, 91(1849):118-152.

-------. "Grote's History of Greece" (II), British Quarterly Review, 13(1851):310-31.
} 
Lindsay, A.D. "Introduction" in Grote's History of Greece, Everyman's edn, London, 1906.

The Historical Socrates and the Platonic Form of the Good, University of Calcutta, Calcutta, 1932.

Lodge, Gonzalez. (trans.), Plato, 'Gorgias', Ginn and Co., London, 1890.

Loenen, D. Protagoras and the Greek Community, Amsterdam, 1940.

Lowndes, William. Remarks on the Life and Writings of Plato, J.McGreery, London, 1827.

Lutoslawski, Wincenty. The Origin and Growth of Plato's Logic, with an account of Plato's style and of the chronology of his writings, Longmans, Green, and co., London and New York, 1897.

Macfait, Ebenezer. Remarks on the Life and Writings of Plato. With Answers to the principal Objections against him; and a general view of his DIALOGUES, Edinburgh (J.Bell), London (A.Millar), 1760.

MacGregor, M.F. The Athenians and their Empire, University of British Columbia Press, Vancouver, 1987.

Mackay, R.W. (trans.), The Sophistes of Plato: A dialogue on true and false teaching, with an introduction on ancient and modern sophistry, Williams and Norgate, London and Edinburgh, 1868.

Macllwaine, W. "The Mission of Socrates", Dublin University Magazine, 82(1873):300-313.

Macllwraith, W. The Life and Writings of George Grote, W.Kent \& co., London, 1885 .

Maguire, Thomas. Essays on the Platonic Ethics, Rivingtons, London, Oxford, Cambridge, 1870.

Mahaffy, J.P. "A Critical Introduction" to V.Duruy's History of Greece, London, 1892.

-.----. A History of Greek Literature, 5th edn (first edn 1890), Macmillan, London, 1910.

Manasse, E.M. "Platonism since the Enlightenment", Dictionary of the History of Ideas, vol.III, ed. by Philip. P. Wiener, Charles Scribner's Sons, New York, 1973, pp. 515-525.

Maurice, F.D. Moral and Metaphysical Philosophy (2 vols.), Macmillan, London, 
1882.

Meiggs, Russell. The Athenian Empire, Clarendon Press, Oxford, 1972.

Mendelssohn, Moses. Phaedon; or, the Death of Socrates, trans. by Charles Cullen, J.Cooper, London, 1789.

Merry, W.W. Aristophanes, 'The Clouds', Clarendon Press, Oxford, 1879.

Mill, James. "Taylor's Translation of Plato", The Literary Journal, 3(1804):449-461, and 577-589.

-.----.. "Taylor's Plato", Edinburgh Review, 14(1809):187-211.

History of British India, vol.I, London, 1817.

Analysis of the Phenomena of the Human Mind, London, 1825.

An Essay on Government, ed. by E.Barker, Cambridge University Press, Cambridge, 1937.

-------. "Education", in W.H.Burston (ed.), James Mill on Education, Cambridge University Press, Cambridge, 1969, pp.41-193.

Mill, J.S. Autobiography, ed. by Jack Stillinger, Oxford University Press, Oxford, London, 1971.

Collected Works, ed. J.M.Robson, University of Toronto Press, Toronto:

"Utilitarianism", vol.X (1969).

"Later Letters of J.S.Mill", vol. XVI (1972).

"On Liberty", vol. XVIII (1977).

"On Representative Government", vol. XCIX (1977).

Essays on Philosophy and the Classics, vol. XI (1978). This vol. includes

Mill's reviews of Grote's History.

"Grote's Aristotle", vol. XI (1978), pp. 473-510.

"Notes on some of the more popular Dialogues of Plato", vol.XI, pp. 175-238.

"Inaugural Lecture at St. Andrews", vol. XXI (1984).

"Grote's Greece", vol. XXV (1986), pp. 1157-64.

"Grote's History of Greece", vol. XXV, pp. 1121-8.

"Grote's Greece", vol. XXV, pp. 1128-34.

Milman, Henry Hart. "Grote's History of Greece", Quarterly Review, 78(1846):113144.

Mistriotis, G. Apologia Sokratous, Athens, 1876.

------. Ta aitia tou archaiou kai tou neoterou politismou, Athens, 1891. 
Mitchell, A.M. (trans.), The Comedies of Aristophanes, vol.I (Preliminary Discourse), J.Murray, London, 1820.

Mitchell, J.M. (ed.), Grote's History of Greece (condensed edn, in one vol.), Routledge, London, 1907.

Mitchell, J.M. "George Grote", Encyclopaedia Britannica, 11th edn, vol.XII, Cambridge University Press, Cambridge, 1910.

Mitchell, T. "Panegyrical Oratory of Greece", Quarterly Review, 27(1822):382-404.

-------. "Greek Courts of Justice", Quarterly Review, 33(1826):332-356.

Mitford, William. The History of Greece, 3rd edn (4 vols.), T.Cadell \& W.Davies, London, 1808.

Momigliano, Arnaldo. George Grote and the Study of Greek History, inaugural lecture delivered at University College London, 19 Feb. 1952, H.K.Lewis \& co., Ltd., London, 1952.

Moint, D.B. "Jowett's Plato", Quarterly Review, 131(1871):492-522.

Montagu, E.W. Reflections on the Rise and Fall of the Antient Republicks. Adapted to the Present State of Great Britain, 2nd edn (first edn 1759), A.Millar, London, 1760 .

Montuori, Mario. Socrates, An Approach, J.C.Gieven, Publisher, Amsterdam, 1988.

Morell, J.D. Manual of the History of Philosophy, London (W.Stewart \& co.), Edinburgh (J.Menzies \& co.), 1885.

Morgan, Caesar. An Investigation of the Trinity of Plato and of Philo Judaeus, ed. by H.A. Holden, 2nd edn, Cambridge (Cambridge University Press), London (John W.Parker), 1853.

Morley, John. The Life of Richard Cobden, Chapman and Hall, London, 1881, vol.I.

Morrison, J.S. "The Place of Protagoras in Athenian public life (460 - 415 B.C.", The Classical Quarterly, 35(1941):1-16.

Muir, J.V. "Protagoras and Education at Thourioi", Greece \& Rome, 29(1982):17-24.

Muller, K.O. Prolegomena zu einer wissenschaftlichen Mythologie, Gottingen, 1825.

A History of the Literature of Ancient Greece, vol.II, trans. by John William Donaldson, J.W.Parker and son, London, 1858. 
Muller-Strubing, H. Aristophanes und die historische Kritik, Leipzig, 1873.

Mure, William. Remarks on two appendices to the second volume, third edition, of $\mathrm{Mr}$ Grote's History of Greece, Longmans, London, 1851.

A Critical History of the Language and Literature of Antient Greece, vol.IV, Longmans, London, 1853.

Murray, Gilbert. A History of Ancient Greek Literature, 2nd edn, William Heinemann, London, 1898.

Nares, R. An Essay on the Demon or Divination of Socrates, T.Payne \& son, London, 1782.

Nevill, D.F. (trans.), Plato. The 'Apology of Socrates', F.E.Robinson and co., London, 1901.

Niebuhr, B.G. Lectures on the History of Rome, trans. by L.Schmitz, Taylor \& Walton, London, 1848.

-------. Lectures on Ancient History, trans. by L.Schmitz (3 vols.), Taylor, Walton, and Maberly, London, 1852.

O'Brien, Michael. "Modern Philosophy and Platonic Ethics", Journal of the History of Ideas, 19(1958):451-472.

Ogilvie, John. The Theology of Plato compared with the Principles of Oriental and Grecian Philosophers, J.Deighton, London, 1793.

Oordt Van, J.W.G. Plato and the times he lived in, James Parker \& co., Oxford, 1895.

Owen, John. "George Grote", Theological Review, 10(1873):503-523.

Packard, Lewis R. "Grote and Curtius", New Englander, 34(1875):123-131.

Packe, M.S.J. The Life of John Stuart Mill, Secker \& Warburg, London, 1954.

Pangle, T.L. (ed.), The Roots of Political Philosophy. Ten Forgotten Socratic Dialogues, Cornell University Press, ithaca and London, 1987.

Paparregopoulos, K. Peri tes arches kai tes diamorphoseos ton phylon tou archaiou hellenikoy ethnous, Athens, 1856.

Istoria toy Ellenikou Ethnous, Athens, 1865.

Pappe, H.O. "The English Utilitarians and Athenian Democracy", in Classical Influences on Western Thought A.D. 1650-1870, ed. by R.R.Bolgar, Cambridge 
University Press, Cambridge and London, 1979.

Pater, Walter. Plato and Platonism, Macmillan, London and New York, 1893.

Petrides, P. Istoria tes Palaias Ellados, Korfoi, 1830.

Philip, J.A. "The Platonic Corpus", Phoenix, 24(1970):296-308.

Pfeiffer, R. History of Classical Scholarship, Clarendon Press, Oxford, 1968.

Plamenatz, John. Man and Society, vol.II, Longmans, London, 1963.

Plato. Dialogues, trans. by Benjamin Jowett, (4 vols), fourth edn, Clarendon Press, Oxford, 1953.

Plutarch. Lives, trans. Bernadotte Perrin, Loeb Classical Library, 1914-26.

Pond, Enoch. Plato: His Life, Works, Opinions and Influence, Hyde, Lord \& Duren, Portland, 1847.

Popper, K.R. The Open Society and its Enemies (2 vols.), George Routledge \& Sons, London, 1943-45.

Poste, Edward. Plato's Philebus, Oxford, 1860.

Potter, J.P. The Religion of Socrates. Dedicated to Sceptics And Sceptic-Makers, London, 1831.

------. The Mysticism of Plato, or Sincerity rested upon reality, Arthur Taylor, London, 1832.

------. Characteristics of the Greek Philosophers. Socrates and Plato, John W.Parker, London, 1845.

Priestley, Joseph. Socrates and Jesus Compared, J.Johnson, London, 1803.

--------. The Doctrines of Heathen Philosophy, compared with those of Revelation, John Binns, Northumberland, 1804.

Pusey, Philip. "Plato, Bacon, and Bentham", Quarterly Review, 61(1838):462-506.

Ranke, L.von. Universal History, trans. by D.C.Torey and G.W.Prothero, Kegal Paul, Trench, \& co., London, 1884.

Rankin, H.O. Sophists, Socratics and Cynics, Croom Helm, London and Canberra, 1983. 
Rawlinson, George. A Manual of Ancient History, Clarendon Press, Oxford, 1869.

Rhodes, P.J. The Athenian Empire, Oxford, 1985.

Riddell, James. (trans.), The 'Apology' of Plato, Clarendon Press, Oxford, 1867.

Ritchie, D.G. Plato, T. \& T.Clark, Edinburgh, 1902.

Ritter, Heinrich. The History of Ancient Philosophy, trans. by A.J.W. Morrison (4 vols.), D.A.Talboys, Oxford, 1838.

Roberts, J.W. City of Sokrates. An Introduction to Classical Athens, Routledge \& Kegan Paul, London and New York, 1984.

Robertson, G.C. "Grote, George", D.N.B. vol.XXIII, London, 1890.

Rogers, B.B. (trans.), Aristophanes, 'The Clouds', Oxford (Francis Macpherson), London (William Pickering), Cambridge (John Deighton), 1852.

The Comedies of Aristophanes, London, 1910, vol.I.

Rollin, Charles. Ancient History, 12th edn, London, 1813.

Romilly, J. de. Thucydides and Athenian Imperialism, trans. by Philip Thody, Blackwell, Oxford, 1963.

-------. La Grece antique a la decouverte de la liberte, de Fallois, Paris, 1989.

Royce, G.M. "Ruskin vs. Gibbon and Grote", New Englander and Yale Review, 45(1886):954-963.

Ryan, Allan. J.S.Mill, Routledge, London and Boston, 1974.

$$
\text { 4th edn, eit. T.L. Thorson }
$$

Sabine, G.H. History of Political Theory, Illinois, 1973.

Sanders, L.C. "Drummond, Sir William", D.N.B., vol.XVI, London, 1888, p.51.

Sandford, D.K. "Bulwer's Rise and Fall of Athens", Edinburgh Review, 65(1837):151177.

Sandys, J.E. A Short History of Classical Scholarship, C.U.P., Cambridge, 1913.

Schiller, F.C.S. Plato or Protagoras? Being a critical examination of the Protagoras' speech in the 'Theaetetus' with some remarks upon error, Oxford (B.H.Blackwell), London (Simpkin, Marshall \& co.), 1908.

Schlegel, Frederick. Lectures on the History of Literature, vol.I, William Blackwood, 
Edinburgh, 1818.

Schleiermacher, F.D.E. "On the Worth of Socrates as a philosopher", trans. by C.Thirlwall, Philological Museum, 2(1833):538-55.

-------. Introductions to the Dialogues of Plato, trans. by William Dobson, Cambridge, 1836.

Schomann, G.F. Athenian Constitutional History, as represented in Grote's History of Greece, trans. by Bernard Bosanquet, James Parker and co., Oxford and London, 1878.

Antiquities of Greece, trans. by E.G.Hardy and J.S.Mann, Rivingtons, Oxford and Cambridge, 1880.

Schwegler, Albert. Handbook of the History of Philosophy, 3rd edn, ed. and trans. by J.H.Sterling, Edmonston \& Douglas, Edinburgh, 1867.

Sewell, William. An Introduction to the Dialogues of Plato, London (J.G.F. \& J.Rivington), Oxford (J.H.Parker), 1841.

Sextus Empiricus. Against the Logicians, trans. R.G.Bury, Loeb Classical Library, 1935.

Shilleto, Richard. Thucydides or Grote? Cambridge (John Deighton), London (Macmillan), Oxford (J.H.Parker), 1851.

Shorey, Paul. Platonism Ancient and Modern, University of California Press, Berkeley, California, 1938.

Sidgwick, H. "The Sophists" (II), Journal of Philology, 5(1873):66-80.

-.--.-. Outlines of the History of Ethics, Macmillan, London, 1896.

------. "The Sophists" (I), in Lectures on the Philosophy of Kant, Macmillan, London, 1905, pp.323-350.

Sinclair, R.K. Democracy and Participation in Athens, Cambridge University Press, Cambridge, 1988.

Smith, Philip. A History of the Ancient World, from the earliest records to the fall of the western empire (3 vols.), fourth edn, J.Murray, London, 1873.

Smith, W. "Grote's History of Greece", Quarterly Review, 99(1856):60-105.

-----.. "George Grote", Quarterly Review, 135(1873):98-137. 
Smith, William Henry. "Grote's History of Greece", Blackwood's Edinburgh Magazine, 62(1847):129-148.

Smyth, C.B. Christian Metaphysics, or Plato, Malebrance and Gioberti, the old and new Ontologists compared with the Modern schools of Psychology, E.Palmer and Son, London, 1851.

Socher, Joseph. Ueber Platons Schriften, Munchen, 1820.

Solmsen, F. "The Academic and Alexandrian Editions of Plato's works", Illinois Classical Studies, 6(1981):102-111.

Sophocles, Oedipus the King, Antigone, trans. F.Storr, Loeb Classical Library, 1912.

Spahn, "George Grote, John Stuart Mill und die antike Demokratie", in Der Klassische Utilitarismus (ed. U.Gahde and W.H.Schrader), Akademie Verlag GmbH, Berlin, 1992.

Spens, H. (trans.), The Republic of Plato in Ten Books, Robert and Andrew Foulis, Glasgow, 1763.

Stanford, C.S. Plato's Apology of Socrates, Crito, and Phaedo, Dublin, 1835.

Stanley, A.P. "History of Greece", Quarterly Review, 86(1850):384-415.

------. "Socrates", Quarterly Review, 88(1850):41-69.

Stanley, Thomas. The History of Philosophy, fourth edn, A.Millar, London, 1743.

Stanyan, Temple. The Grecian History (2 vols.), London, 1782.

Starkie, W.J.M. (trans.), The 'Clouds' of Aristophanes, Macmillan, London, 1911.

Stephen, Leslie. "Cameron, Charles", D.N.B., London, 1886, vol.III, pp.288-9.

-------. "Lytton, Edward George Earle Lytton Bulwer", D.N.B., vol.XXXIV, Smith, Elder, \& co., London, 1893, pp.380-383.

------. "James Mill", D.N.B., vol.XXXVII, London, 1894.

------.. The English Utilitarians, vols II and III (on James Mill and J.S.Mill), Duckworth and co., London, 1900.

Stillinger, J (ed.) The Early Draft of John Stuart Mill's 'Autobiography', Urbana, 1961.

Stirling, J.H. "Annotations" in Schwegler's Handbook of the History of Philosophy, 
Edinburgh, 1867.

Stock, George. (trans.), The 'Apology' of Plato, Clarendon Press, Oxford, 1887.

Stockton, David. The Classical Athenian Democracy, Oxford University Press, Oxford and New York, 1990.

Stone, I.F. The Trial of Socrates, Little, Brown and co., Boston, Toronto, 1988.

Strumpell, Ludwig. Die Geschichte der Praktischen Philosophie der Griechen vor Aristoteles, Leopold voss, Leipzig, 1861.

Suckow, G.F.W. Die Wissenschaftliche und Kunstlerische Form der Platonischen Schriften, Berlin, 1855,

Suvern, J.W. Two Essays on 'The Clouds' and on 'The Geras' of Aristophanes, trans. by W.R.Hamilton, J.Murray, London, 1836.

Sydenham, F. A Synopsis or General View of the Works of Plato, S.Richardson, London, 1759.

------. The Greater Hippias, London, 1759.

-----.. The Lesser Hippias, London, 1761.

-----. The Banquet, London, 1767.

-.-.-. The First Alcibiades, London, 1768.

----... The Second Alcibiades, London, 1776.

------. Philebus, London, 1779.

Sykes, A.A. Principles and Connexion of natural and revealed religion distinctly considered, London, 1740.

Tayler, Lewis. Plato Contra Atheos. Plato against the Atheists, Harper \& Brothers, New York, 1854.

Taylor, A.E Plato the man and his work, seventh edn, Methuen, London and New York, 1960.

Taylor, Thomas and Sydenham, Floyer. The Works of Plato, viz. His Fifty-five Dialogues and Twelve Epistles (5 vols.), R.Wilks, London, 1804.

Taylor, T. Miscellanies, C.Whittingham, London, 1805. 
Collectanea, C.Whittingham, London, 1806.

------. The Commentaries of Proclus (2 vols.), A.J.Valpy, London, 1820.

Temple, William. Plato and Christianity, Macmillan, London, 1916.

Tennemann, William Gottlieb. System der Platonischen Philosophie (4 vols), Leipzig, $1792-5$.

------. "Life of Plato", in Edwards and Park (ed.), Selections From German Literature, Andover, 1839, pp.311-367.

A Manual of the History of Philosophy, trans. by A.Johnson, Oxford, 1832, revised and continued by J.R.Morell, Henry G.Bohn, London, 1852.

Theobald, Lewis, Plato's Dialogue of the Immortality of the Soul, London, 1713.

Thirlwall, Connop. The History of Greece (8 vols.), Longman and John Taylor, 18351843.

Thomas, William. The Philosophic Radicals, Nine Studies in Theory and Practice 1817-1841, Clarendon Press, Oxford, 1979.

Mill, Oxford University Press, Oxford and New York, 1985.

Thompson, D.F. John Stuart Mill and Representative Government, Princeton University Press, Princeton, 1976.

Thompson, W.H. "The 'Nubes' of Aristophanes", Journal of Philology, 12(1882):169190.

Thomsen, Rudi. The Origins of Ostracism, Copenhagen, 1972.

Thursfield, James R. "Mr Grote's Plato", Westminster Review, 84(1865):459-482.

Thucydides. History, trans. B.Jowett (2 vols), second edn, Clarendon Press, Oxford, 1900.

Tollemache, L.A. "George Grote", in Safe Studies, fourth edn, William Rice, London, 1895, pp.131-145.

Toulmin, Joshua. Dissertations on the Internal Evidences and Excellence of Christianity: And on the character of Christ, compared with that of some other celebrated founders of Religion or Philosophy, J.Johnson, London, 1785.

Turner, E.G. Athenian Books in the fifth and fourth centuries B.C., inaugural lecture delivered at University College London, H.K.Lewis \& co., Ltd., London, 1952. 
Turner, F.M. The Greek Heritage in Victorian Britain, Yale University Press, New Haven and London, 1981.

Ueberweg, F. Untersuchungen uber die Echtheit und Zeitfolge Platonischer Schriften, und uber die Hauptmomente aus Platons Leben, Wien, 1861.

History of Philosophy (2 vols.), trans. from the 4th German edn (first edn 1862-66) by G.S.Morris, Scribner, Armstrong \& co., New York, 1874.

Versenyi, Laszlo. Socratic Humanism, Yale University Press, New Haven and London, 1963.

Vlastos, G. Socrates, Ironist and Moral Philosopher, Cambridge, 1991.

Walker, E.M. "The Periclean Democracy", Cambridge Ancient History (ed. J.B.Bury, S.A.Cook, F.E.Adcock), Cambridge, 1927, pp.98-112.

Warburton, William. The Divine Legation of Moses, Fletcher Gyles, London, 1738.

Wayte, W. (trans.), Platonis Protagoras, 2nd edn, Cambridge (Deighton, Bell, \& co.), London (Bell \& Daldy), 1871.

Wells, George Henry. (trans.), The 'Euthydemus' of Plato, London (George Bell and sons), Cambridge (Deighton), 1881.

Welwood, James. The Banquet of Xenophon. Done from the Greek, with an Introductory Essay to Lady Jean Douglass, concerning the Doctrine, and Death of Socrates, Robert \& A.Foulis, Glasgow, 1750.

Wenley, R.M. Socrates and Christ. A Study in the Philosophy of Religion, William Blackwood and sons, Edinburgh and London, 1889.

West, A.B. "Pericles' Political Heirs" (I), Classical Philology, 19(1924):124-146.

Westerink, L.G. (ed.) Anonymous Prolegomena to Platonic Philosophy, North-Holland Company, Amsterdam, 1962.

Wheelwright, C.A. The Comedies of Aristophanes, vol. I, D.A.Talboys, Oxford, 1837.

Whewell, William. "Grote's Plato", Fraser's Magazine, 73(1866):411-423.

-------. The Platonic Dialogues for English Readers (3 vols.), Macmillan, London and Cambridge, 1859-61.

Whibley, L. Political Parties in Athens during the Peloponnesian War, 2nd edn, C.U.P., Cambridge, 1889. 
Windelband, W. History of Ancient Philosophy, trans. by H.E.Cushman, from the 2nd German edn (1893), Sampson Low, Marston \& co., Ltd., London, 1900.

Wiggers, G.F. "A Life of Socrates", in PLATO, The 'Apology of Socrates', the 'Crito' and Part of the 'Phaedo', ed. by W.Smith, Taylor Walton and Maberly, London, 1852.

Willey, B. Nineteenth Century Studies, Coleridge to Matthew Arnold, Harper Torch Books, New York, 1949.

Williams, G.L. "History and History: J.S.Mill on the Greeks", Polis, vol.4, n.2 (1982):1-17.

Winspear, A.D. The Genesis of Plato's Thought, 2nd edn (first edn 1940), S.A.Russell, New York, 1956.

Woolsey, T.D. (trans.), The 'Gorgias' of Plato, James Munroe and co., Boston and Cambridge, 1848.

Woodhead, A.G. "Thucydides' Portrait of Cleon", Mnemosyne, 13(1960):289-318.

Wroth, W. "Mitford, William", D.N.B., vol.XXXVIII, Smith, Elders and co., London, 1894.

Xenophon, Hellenica, trans. C.L.Brownson, Loeb Classical Library, Harvard University Press, Cambridge, Mass., 1918-21.

-------. Memorabilia, trans. E.C.Marchant, Loeb Classical Library, 1923.

[Xenophon]. Athenaion Politeia, trans. James A.Petch, Basil Blackwell, Oxford, 1926.

Young, William. The History of Athens; including a commentary on the Principles, Policy, and Practice of Republican Government, 3rd edn (first edn, 1777, as The Spirit of Athens), W.Bulmer and co., London, 1804.

Zeller, Eduard. Platonische Studien, Tubingen, 1839.

-----. "The development of monotheism among the Greeks", Contemporary Review, 4(1867):359-379.

-------. Plato and the Older Academy, trans. by S.F.Alleyne and A.Goodwin, Longmans, Green \& co., London, 1876.

-------.. Socrates and the Socratic Schools, 3rd edn, trans. by Oswald J.Reicher, Longmans, London, 1885.

Zimmern, Alfred. The Greek Commonwealth, fifth edn, Oxford University Press, 
Oxford, 1961. 